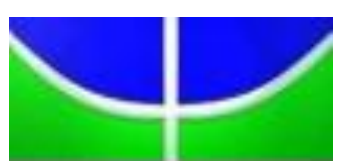

UNIVERSIDADE DE BRASÍLIA

Faculdade de Educação

Programa de Pós-Graduação em Educação

ADRIANA ZIEMER GALLERT

A CONSTITUIÇÃO SUBJETIVA DO PROFESSOR ENQUANTO SUJEITO DA SUA AÇÃO

Brasília

2016 


\section{A CONSTITUIÇÃO SUBJETIVA DO PROFESSOR ENQUANTO SUJEITO DA SUA AÇÃO}

Tese apresentada ao Programa de Pósgraduação em Educação da Faculdade de Educação, da Universidade de Brasília - UnB, na área de concentração Escola, Aprendizagem, Ação Pedagógica e Subjetividade na Educação, como parte dos requisitos para obtenção do título de Doutora em Educação.

Orientadora: Prof $\stackrel{a}{ }$. Drª . Maria Carmen Villela

Rosa Tacca

\section{Brasília}


Ficha catalográfica elaborada automaticamente, com os dados fornecidos pelo(a) autor(a)

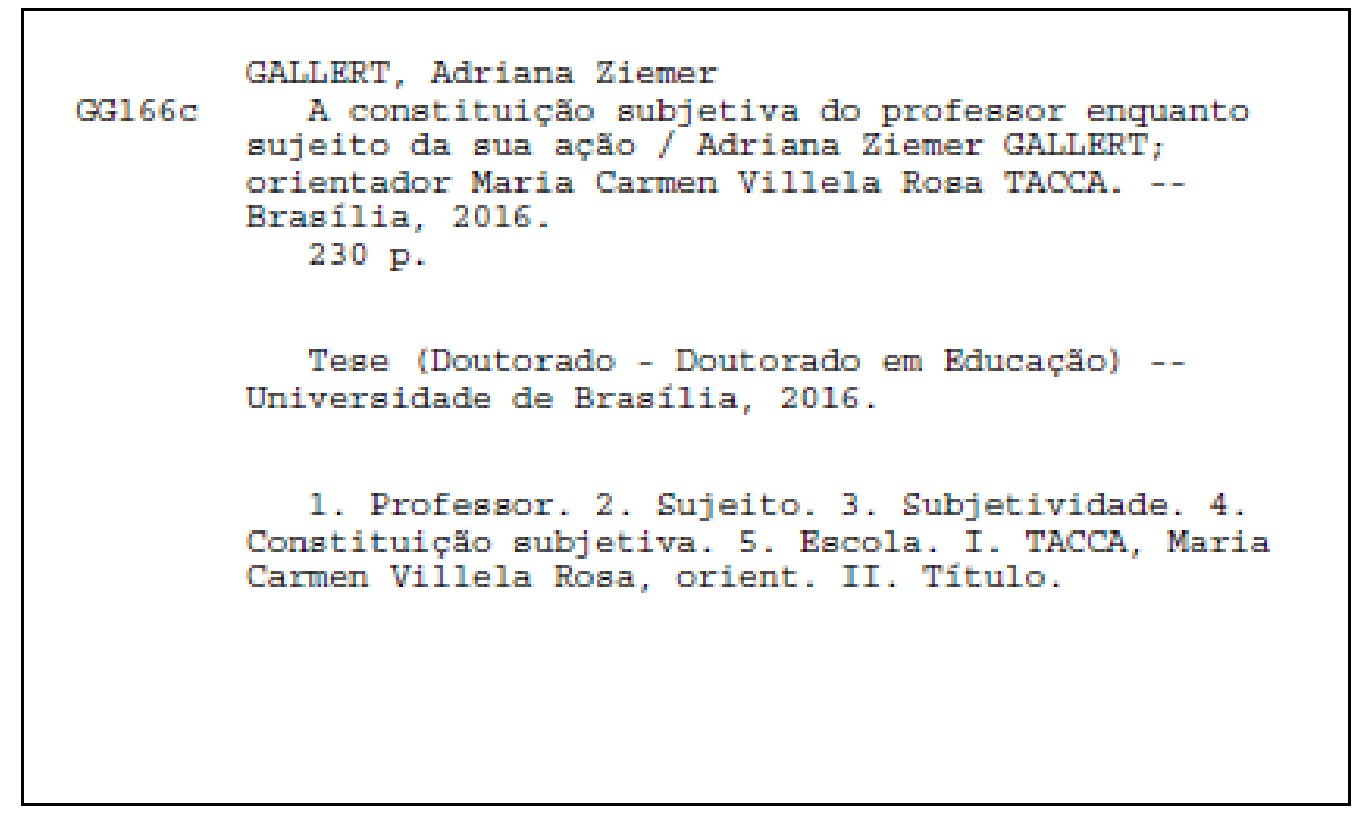




\title{
A CONSTITUIÇÃO SUBJETIVA DO PROFESSOR ENQUANTO SUJEITO DA SUA AÇÃO
}

\author{
Tese apresentada ao Programa de Pós- \\ graduação em Educação da Faculdade de \\ Educação, da Universidade de Brasília - UnB, \\ na área de concentração Escola, \\ Aprendizagem, Ação Pedagógica e \\ Subjetividade na Educação, como parte dos \\ requisitos para obtenção do título de Doutora \\ em Educação.

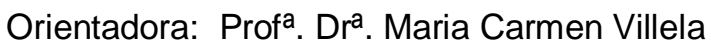 \\ Rosa Tacca
}

Brasília, 18 de Agosto de 2016.

\section{BANCA EXAMINADORA}

Profa. Dra. Maria Carmen Villela Rosa Tacca (orientadora)

Faculdade de Educação - Universidade de Brasília/UnB

Profa. Dra. Ana Valéria Marques Fortes Lustosa (membro externo)

Centro de Ciências da Educação - Universidade Federal do Piauí/UFPI

Profa. Dra. Lucia Helena Cavasin Zabotto Pulino (membro externo) Instituto de Psicologia - Universidade de Brasília/UnB

Prof. Dr. Fernando Luis González Rey (membro interno) Faculdade de Educação - Universidade de Brasília/UnB

Profa. Dra. Cristina Massot Madeira Coelho (membro interno)

Faculdade de Educação - Universidade de Brasília/UnB

Profa. Dra. Albertina Mitjáns Martinéz (suplente)

Faculdade de Educação - Universidade de Brasília/UnB 
Dedico este trabalho a todos os professores que, assim como Nícolas, vivem intensamente a docência e a educação , com dedicação e comprometimento, na perspectiva de promover a aprendizagem e o desenvolvimento dos seus alunos. 


\section{AGRADECIMENTOS}

Ao concluir este trabalho muitas emoções se misturam e uma palavra emerge com força: GRATIDÃO! Junto a ela se enlaça uma teia de vivências, recordações, lugares, sentimentos e pessoas que participaram de cada momento que constituiu todo esse processo!

Gratidão a Deus, que me presenteou com a bênção e a oportunidade de viver momentos tão preciosos! Como o salmista Davi, eu louvo: "Tu, ó Senhor Deus, és tudo o que tenho. O meu futuro está nas tuas mãos, tu diriges a minha vida. Como são boas as bênçãos que me dás! Como são maravilhosas!" (Salmo 16.5).

Gratidão a minha Família, ao meu marido e amigo Claudio e às minhas filhas Bianca e Bárbara. Agradeço pela paciência com tantas ausências e pelo apoio, pois sei que foi difícil apoiar em diversos momentos. Conseguimos e concluímos, juntos!

Gratidão aos meus pais, Albino e Tereza, pelo valor que os estudos e a educação têm na sua vida e pela maneira simples e firme como orientaram a nossa trajetória familiar desde a infância. Agradeço pela presença, mesmo a quilômetros de distância, pelo incentivo e apoio recebido!

Gratidão aos meus irmãos, Marcos e Silvana, pelo apoio e carinho no decorrer de mais essa caminhada!

Gratidão à Universidade de Brasília e a todas as pessoas que a fazem existir e acontecer.

Gratidão e carinho especial à minha orientadora, Profa. Dra. Maria Carmen Villela Rosa Tacca, pela humanidade e sensibilidade. Agradeço imensamente pelos questionamentos incansáveis, pelas longas conversas que tivemos, pela convivência e amizade. Foram momentos inesquecíveis que se constituíram em intensos processos de produção subjetiva! De coração, muito obrigada por você ser a pessoa incrível que é!

Gratidão especial ao meu autor e inspirador, Prof. Dr. Fernando González Rey, que, como pesquisadora, tive o privilégio de tê-lo presente no percurso da minha trajetória! 
Gratidão à Profa. Dra. Cristina Massot Madeira Coelho e à Profa. Dra. Albertina Mitjáns Martinéz pelas valiosas contribuições e reflexões no decorrer da minha caminhada como pesquisadora!

Gratidão à Profa. Dra. Ana Valéria Marques Fortes Lustosa, à Profa. Dra. Lucia Helena Cavasin Zabotto Pulino e à Profa. Dra. Susana Inês Molon pelas contribuições nas bancas de qualificação e defesa da tese.

Gratidão ao Prof. Dr. Bernardo Kipnis, à Profa. Dra. Kátia Augusta Curado Pinheiro Cordeiro, à Profa. Dra. Otilia Dantas, à Profa. Dra. Vera Lessa Catalão e à Profa. Dra. Maria Abádia da Silva, por compartilharem os seus conhecimentos nas aulas que convivemos no decorrer das disciplinas.

Gratidão aos professores da escola, de Palmas - TO, que acolheram com tanto carinho a minha presença na vida cotidiana da sua profissão!

Gratidão ao Professor Nícolas, que viveu intensamente a pesquisa durante 0 período em que estive na escola, proporcionando que essa tese se concretizasse. Agradeço pela confiança em compartilhar informações tão valiosas! Desejo que a sua vida seja uma inspiração para que outros professores possam refletir sobre a sua profissão e o seu viver!

Gratidão aos amigos do curso pelos momentos especiais que juntos convivemos e também a todas as amigas que me acolheram nas minhas idas e vindas de Palmas a Brasília!

Gratidão aos colegas de trabalho do Centro Universitário Luterano de Palmas, de forma especial, Kelen, Adriano, Parcilene e Diêmy, que apoiaram e possibilitaram conciliar a vida em Brasília e Palmas para que essa etapa da minha vida se concretizasse.

Gratidão ao meu amigo Fabiano, que deu o incentivo que faltava, certo dia, quando pensava em desistir do processo seletivo do doutorado: "Mas você não vai nem tentar?". Obrigado, amigo!

Gratidão aos amigos de Palmas e vários outros lugares, que me incentivaram e apoiaram com palavras de ânimo e orações para que mais esse sonho se tornasse uma realidade na minha vida!

A todos e a todas... Recebam o meu carinho e gratidão! 
J.J "Nada do que foi será De novo do jeito que já foi um dia Tudo passa tudo sempre passará. $A$ vida vem em ondas como o mar Num indo e vindo infinito. Tudo o que se vê não é Igual ao que a gente viu a um segundo Tudo muda o tempo todo no mundo Não adianta fugir, nem mentir prá si mesmo agora Há tanta vida lá fora E aqui dentro sempre, Como uma onda no mar." $\mathrm{J}$

(Lulu Santos)

"Aquele que ensina, esmere-se no fazê-lo." Romanos 12.7 


\section{RESUMO}

A presente pesquisa teve como objetivo analisar a constituição subjetiva do professor que se configura enquanto sujeito da sua ação. Assumimos a compreensão do conceito de sujeito a partir da Teoria da Subjetividade, de González Rey, que o define como a pessoa capaz de gerar um espaço próprio de subjetivação em suas diferentes atividades humanas. Adotamos procedimentos metodológicos alicerçados na Epistemologia Qualitativa, elaborada pelo mesmo autor, a partir dos seguintes princípios: o caráter construtivo-interpretativo do conhecimento; o caráter dialógico da investigação; e o valor do estudo de casos singulares como instância legítima de produção do conhecimento. A pesquisa realizou-se em uma escola pública de Ensino Médio, em Palmas - TO, com o estudo de caso de um professor, a quem denominamos de Nícolas, selecionado a partir do acompanhamento de um grupo de docentes. No processo de construção das informações realizamos dinâmicas conversacionais, observações, discussão em grupo, completamento de frases, Diário e Linha do Tempo. A construção interpretativa possibilitou compreender a constituição subjetiva do Professor Nícolas a partir de elementos subjetivos que o configuravam no seu momento atual, os quais se constituíram no decorrer da sua história de vida, possibilitando que atuasse e vivesse a docência assumindo-se enquanto sujeito da sua ação. A pesquisa possibilitou compreender que, atuar enquanto sujeito, não significa ser um professor plenamente feliz e satisfeito com a profissão. Ele busca alternativas para a satisfação pessoal e profissional, mesmo em meio aos problemas, assumindo posturas ativas e propositivas. Esse processo de produção subjetiva o fortalece em relação a querer permanecer na profissão, a recriar as suas práticas pedagógicas, a buscar e criar possibilidades para sua atuação junto ao aluno. Portanto, concluímos que constituir-se enquanto sujeito articulase com produções subjetivas que o docente elabora no curso da sua trajetória, incluindo nesse processo o valor que a profissão tem na sua vida. Destacamos ainda que o nosso foco não foi traçar o perfil do bom professor ou idealizá-lo, pois a constituição subjetiva é única e singular em cada docente. Ao invés disso, buscamos construir uma compreensão complexa e sensível sobre a subjetividade de um professor real, concreto e único, que vivia intensamente as relações sociais, a vida e a docência. Tal compreensão possibilita reflexões frente aos desafios do cotidiano escolar e sinaliza possibilidades para ações formativas, assumindo-se como referência os movimentos subjetivos e processos de desenvolvimento do próprio professor.

PALAVRAS-CHAVE: Professor. Sujeito. Subjetividade. Constituição subjetiva. Escola. 


\begin{abstract}
This research objective was to analyze the subjective constitution of the teacher who sets up as the subject of his action in the space of his educational work. We assume the understandingof the concept of subject from the Theory of Subjectivity, of González Rey, who defines it as a person able to create an own space of subjectivation in his different human activities. We adopt methodological procedures grounded in the Qualitative Epistemology, elaborated by the same author, from the following principles: the constructiveinterpretative character of knowledge; the dialogic character of research; and the value of singular cases study as legitimate instance of knowledge production. The research was conducted in a public high school, in Palmas TO, with the case study of a teacher, which we named Nícolas, selected from the monitoring of a teachers group. In the information construction process, we conducted conversational dynamics, observations, group discussion, completionof sentences, Diary and Timeline. The interpretative construction enabled to understand the subjective constitution of teacher Nícolas from subjective elements that molded him in his actual moment, which were formed in the course of his life story, allowing to act and live teaching as the subject of his action. The research enabled to understand that to actas subject doesn't mean to be a completely happy and satisfied teacher. He looks for alternatives to personal and professional satisfaction, even amid the problems, taking active and positives postures. This process of subjective production strengthens him to remain in the profession, to recreate his pedagogical practices, to search and create possibilities for his acting with the students. Therefore, we concluded that becoming a subject articulates with subjective productions that the teacher prepares during his history, including in this processes the value that the profession has in his life. We also highlight that our focus was not to trace the good teacher profile or idealize it, for the subjective constitution is unique and singular in each teacher. Instead, we seek to build a complex and sensitive understanding of the subjectivity of a real, concrete and unique teacher that intensely lived social relations, life and teaching. This understanding enables reflections of daily school challenges and indicates possibilities for training activities, taking as reference the subjective movements and development processes of the teacher himself.
\end{abstract}

KEY WORDS: Teacher. Subject. Subjectivity. Subjective constitution. School. 


\section{RESUMEN}

La presente investigación tuvo como objetivo analizar la constitución subjetiva del profesor que se configura en cuantoes sujeto de acción en el espacio de su trabajo educativo. Asumimos la comprensión del concepto del sujeto a partir de la Teoría de la Subjetividad, de González Rey, que la define como la persona capaz de generar un espacio propio de subjetivación en sus diferentes actividades humanas. Adoptamos procedimientos metodológicos baseados en la Epistemología Cualitativa, elaborada por el mismo autor, apartir de los siguientes principios: carácter constructivo-interpretativo del conocimiento; carácter dialógico de la investigación; y valor del estudio de casos singulares como instancia legítima de producción del conocimiento. La investigación se realizó en una escuela pública de Enseñanza Media, en Palmas - TO, mediante el estudio de caso de un profesor, a quien denominamos de Nicolás, seleccionado a partir del acompañamiento de un grupo de docentes. En el proceso de construcción de las informaciones realizamos dinámicas de conversación, observaciones, discusión en grupo, completamiento de frases, Diario y Línea de Tiempo. La construcción interpretativa posibilitó comprender la constitución subjetiva del Profesor Nicolás apartir de elementos subjetivos que lo configuraban en su momento actual, los cuales se constituyeron en el curso de su historia de vida, posibilitando que actuase, viviese la docencia asumiéndose como sujeto de su acción. La investigación posibilitó comprender que, actuar como sujeto, no significa ser un profesor completamente feliz y satisfecho con la profesión. Él busca alternativas para la satisfacción personal y profesional, aún en medio de problemas, asumiendo posturas activas y propositivas. Este proceso de producción subjetiva lo fortalece en relación a querer permanecer en la profesión, a recrear sus prácticas pedagógicas, a buscar y crear posibilidades para su actuación con el alumno. Por lo tanto, concluimos que constituirse mientras se es sujeto, se articula con producciones subjetivas que el docente elabora en el curso de su trayectoria, incluyendo en este proceso el valor que la profesión tiene en su vida. También destacamos que nuestro enfoque no fue trazar el perfil del buen profesor ni idealizarlo, pues la constitución subjetiva es única y singular en cada docente. En lugar de eso, buscamos construir una comprensión más compleja y sensible sobre la subjetividad de un profesor real, concreto y único, que vivía intensamente las relaciones sociales, la vida y la docencia. Tal comprensión posibilita reflexiones frente a desafíos del cotidiano escolar y señala posibilidades para acciones formativas, asumiéndose como referencia los movimientos subjetivos y procesos de desenvolvimiento del propio profesor.

PALABRAS CLAVE: Profesor. Sujeto. Subjetividad. Constitución subjetiva. Escuela. 


\section{SUMÁRIO}

INTRODUÇÃO

1 DISCUSSÃO TEÓRICA

1.1 A história da profissão da docência e a constituição subjetiva do professor: tecendo reflexões sobre a trama de dois processos complexos

1.1.1 Retomando a história da profissão da docência: uma trajetória que constitui subjetivamente os professores

1.1.2 História da docência e constituição subjetiva do professor: que relação há entre essas abordagens?

1.2 Sujeito e subjetividade: perspectivas teóricas e epistemológicas

2 REVISÃO DE LITERATURA

2.1 Pesquisas sobre o professor na perspectiva da sua constituição subjetiva

3 BASE EPISTEMOLÓGICA E METODOLÓGICA

3.1 Base epistemológica da pesquisa: a opção pela Epistemologia Qualitativa

3.2 Percurso metodológico: uma trajetória construída processualmente ..... 80

3.2.1 A escolha da escola 80

3.2.2 A construção do cenário social da pesquisa 83

3.2.3 A decisão em relação aos professores que integrariam o estudo de casos 85

3.2.4 Os instrumentos utilizados no processo de construção das informações $\quad 90$

3.2.5 O processo da construção interpretativa das informações da pesquisa .... 93 
4 CONSTRUÇÃO INTERPRETATIVA A PARTIR DAS INFORMAÇÕES GERADAS NA PESQUISA ........................................................ 98

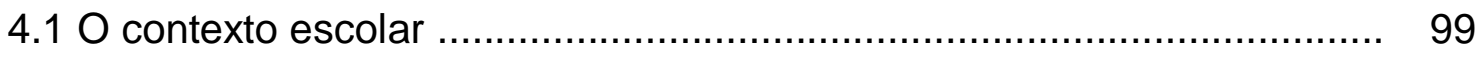

$4.2 \mathrm{O}$ estudo de caso do Professor Nícolas .............................................. 108

4.2.1 Nícolas: vida $\Leftrightarrow$ profissão .............................................................. 108

4.2.2 Nícolas: um professor $\Leftrightarrow$ um lugar: o lugar de viver a docência ................ 113

4.2.3 Nícolas: as pessoas e seus motivos .................................................... 120

4.2.4 Nícolas: o novo e as mudanças ......................................................... 142

5 PRODUÇÃO TEÓRICA CONCLUSIVA …………................................. 179

CONSIDERAÇÕES FINAIS ......................................................... 191

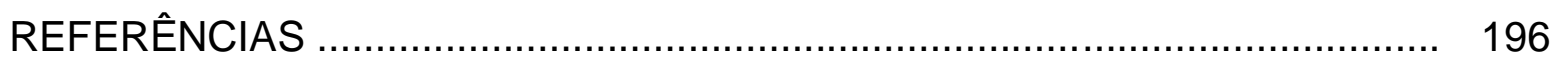

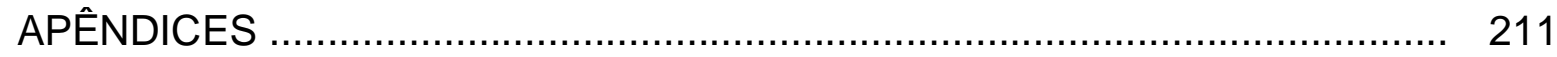


INTRODUÇÃO 


\section{INTRODUÇÃO}

A realização de uma pesquisa acontece de maneira imbricada com a subjetividade do pesquisador que a propõe. Os interesses, as inquietações, as reflexões e os questionamentos sobre a realidade explicitam as opções do pesquisador, as quais se apresentam de maneira articulada com a sua constituição subjetiva. Trajetórias e histórias se entrecruzam nas situações vividas, levando o pesquisador a destacar algo a ser pesquisado e fazer suas escolhas em relação ao tema e problema que busca compreender e analisar.

Considerando tal premissa, inicio o percurso desse trabalho acadêmico apresentando os motivos que me lançaram ao desafio de empreender uma pesquisa em profundidade sobre o professor enquanto sujeito da sua ação. Inicialmente destaco o lugar a partir do qual vejo, sinto e vivo o tema da minha pesquisa: sou professora. Portanto, vivencio cotidianamente os desafios que a relação pedagógica entre professores e alunos traz no âmago dessa profissão.

Além do trabalho como professora atuei também como Coordenadora Pedagógica em escolas de Educação Básica durante onze anos da minha carreira profissional. Considero que os desafios vividos nesse período foram a gênese do interesse pelos estudos sobre a subjetividade do professor. Um grupo de professores, assim como uma turma de alunos, se constitui pelo encontro de trajetórias de vida únicas e singulares, que passam a socializar, interagir e compartilhar experiências, vivências, sentimentos e emoções no cotidiano da escola. Tal processo não é simples, mas é permeado por conflitos e interesses pessoais e coletivos. Nesse ínterim, o Coordenador Pedagógico, como profissional que atua junto aos professores, assume também o desafio dos processos necessários à tomada de decisões e encaminhamentos para que a escola alcance o objetivo maior da sua 
existência, ou seja, a promoção da aprendizagem e do desenvolvimento dos alunos.

No período em que vivi a Coordenação Pedagógica, tive o privilégio de trabalhar com grupos de professores em que havia aqueles que provocavam os colegas, e também a mim, à reflexão e ao questionamento em relação às situações da escola, do sistema educacional e da profissão. Suas inquietações instigavam a divergência de posicionamentos e ações, colocandome, como Coordenadora Pedagógica, em complexas situações de resolução de conflitos, incitando a reflexão e a busca pela compreensão do funcionamento desses coletivos, sempre tão heterogêneos.

Uma questão inquietante na compreensão da complexidade desses grupos relacionava-se aos posicionamentos tão diversos quando discutíamos os problemas da escola e planejávamos ações na perspectiva de encontrar possibilidades viáveis para a nossa realidade. No contexto desses momentos evidenciava-se um forte paradoxo entre aqueles que estavam dispostos a refletir, planejar e agir juntos, e aqueles que criticavam, estavam desanimados ou até já haviam desistido da profissão. Ambos os grupos tinham as suas forças e a sua resistência no embate de ideias e propostas. Enquanto parte do grupo era propositivo e ativo frente às situações vividas, outra parte assumia a postura da queixa e/ou da busca dos culpados, justificando, de certa forma, sua oposição em relação à transformação da realidade.

Ao longo da minha trajetória profissional, percebi que esse paradoxo se apresenta como uma característica que constitui os grupos de professores, como um desafio vivido na tensão do cotidiano das escolas. Chegar a essa reflexão motivou-me ao desafio de empreender a compreensão científica de tal questão, inserindo-se, nesse contexto, a pesquisa desenvolvida no Mestrado. Na ocasião tive a oportunidade de conhecer a Teoria da Subjetividade, de González Rey (1997, 2004a, 2005a, 2005b, 2011b), a partir da qual investiguei a produção de sentidos subjetivos dos professores no enfrentamento das adversidades da docência, analisando o movimento complexo entre suas expectativas, realizações e frustrações em relação à profissão (GALLERT, 2010). 
O contexto escolar estudado no Mestrado, uma escola pública de Ensino Fundamental, em Palmas - TO, se caracterizava por diversas adversidades com as quais os professores conviviam diariamente na realização do seu trabalho. Ao vivenciarem as situações e adversidades de um mesmo contexto escolar, percebi que os professores se posicionavam de maneiras diversas, tendo em vista a forma como subjetivavam essa realidade. Assim, chamaram atenção, principalmente, os posicionamentos de dois professores na vivência dos desafios do cotidiano. Enquanto a professora assumia uma posição de enfrentamento dos problemas, articulando-se e buscando parcerias para realizar ações de solução, o professor não compreendia como seus os desafios do contexto, e colocava no outro a necessidade da mudança, a fim de que tivesse a condição ideal para fazer o seu trabalho.

O alcance da construção interpretativa dessa pesquisa levantou dúvidas e questionamentos em relação à subjetividade desses professores, provocando o movimento de busca e aprofundamento científico da temática. Esse processo se configurou como a abertura de uma nova zona de sentido, ou seja, a construção de um conhecimento como "uma forma de gerar inteligibilidade sobre uma zona da realidade estudada" (GONZÁLEZ REY, 2005b, p. 153). Assim, considerando a complexidade do atual contexto educacional, decidi pela continuidade do estudo do tema e optei pelo aprofundamento da compreensão sobre a subjetividade de professores que vivem a docência de maneira ativa e propositiva frente aos problemas do cotidiano.

Entendo que a compreensão da constituição subjetiva de professores que, enquanto sujeitos, encontram e criam possibilidades no contexto escolar em que atuam, pode ajudar os grupos escolares a trabalharem de maneira mais articulada entre si, compreendendo-se mutuamente em seus processos de desenvolvimento. Isso não significa que essa compreensão tornaria as relações sociais harmônicas ou que teríamos uma resposta para a complexidade das situações que vivemos no cotidiano das escolas. Ao invés disso, busco contribuir com construções interpretativas frente às produções subjetivas que integram os posicionamentos, as ações e 
as proposições de professores que vivem a docência como um cenário de possibilidades de intervenção.

Assim, frente ao exposto, a pesquisa norteou-se assumindo a seguinte questão como problema para a construção das informações: que elementos subjetivos constituem a subjetividade do professor configurando-o enquanto sujeito da sua ação? Partimos da compreensão de subjetividade assumindo os pressupostos teóricos defendidos por González Rey (2004a, 2005b), para quem a subjetividade humana se constitui como um sistema complexo, contraditório, dinâmico e aberto, que se faz e refaz constantemente no processo contínuo da produção de sentidos subjetivos. Tal produção organiza-se de infinitas maneiras na vida das pessoas, constituindo configurações subjetivas, que não são estáticas e rígidas, mas são organizações subjetivas fluidas e que se modificam nos processos vividos. Assim, no nosso caso, a análise das configurações subjetivas possibilita uma compreensão mais aprofundada sobre a subjetividade em um dado momento da vida dos professores.

Nessa perspectiva, a delimitação da zona de sentido (GONZÁLEZ REY, 1997, 2005b) que pesquisamos, buscando esse aprofundamento, difere de outras investigações que analisam a constituição do professor a partir de outras abordagens. Tais estudos buscam, por exemplo, identificar características pessoais para traçar o perfil do professor ideal, do bom professor, do professor bem-sucedido, do professor de sucesso ou do professor eficaz (ALBUQUERQUE, 2010; BÜHLER, 2010; CUNHA, 2000; FUKUDA; PASQUALI, 2002; MIRANDA, 2012; SANTOS, M. S., 2010; SILVA, S., 2014; SOUZA et al, 2009). Também encontramos pesquisas nessa perspectiva em publicações internacionais, como por exemplo, em Miller (2012), Majid, Ali e Alias (2014), Miron e Mevorach (2014), Vlad e Ciascai (2014), Maynes e Hatt (2015), Trammell e Aldrich (2016), que buscam identificar características do bom professor, tendo em vista alcançar resultados satisfatórios no processo de ensino e aprendizagem. Trilhar esse caminho seria argumentar sobre um perfil padronizado e idealizado para o professor, como se houvesse um referencial a ser seguido por todos os profissionais que querem ser considerados como bem qualificados no exercício da docência. 
Além disso, a pesquisa que propomos também difere de pesquisas que estudam a constituição subjetiva do professor alicerçadas em abordagens como, por exemplo, a psicanálise (ANDRADE, 2008; SALUM, 2012; ALTARUGIO, 2007; OLIVEIRA, J. G. M., 2011) e os estudos foucaultianos (ANDRADE, 2008; SALUM, 2012; SILVA, M. T., 2014). Entendemos que tais referências teóricas, apesar das contribuições que trouxeram ao percurso histórico da Psicologia e Filosofia, partem de um paradigma que limita a compreensão do momento histórico complexo que vivemos (GONZÁLEZ REY, 2004a, 2005b).

As situações vividas nas escolas trazem inúmeros desafios ao professor, razão pela qual alicerçamos a nossa pesquisa em uma teoria que entendemos como coerente com tal complexidade, ou seja, a Teoria da Subjetividade, elaborada pelo pesquisador González Rey (1997, 2004a, 2005a, 2005b, 2011b). A partir de investigações nas áreas da saúde, da psicologia e da educação, essa teoria se constitui em um referencial teórico e epistemológico, tendo em vista superar a visão fragmentada do sujeito no decorrer da história da psicologia. Assim, o autor elabora uma perspectiva complexa, dialética e histórico-cultural de análise dos sujeitos singulares concretos, nas relações sociais que estabelecem no cotidiano da sua vida.

A compreensão da subjetividade como um sistema amplo e complexo expande as possibilidades de análise tanto da sociedade como das pessoas, contribuindo para que as situações possam ser compreendidas em maior profundidade. Nessa perspectiva, o valor heurístico da nossa pesquisa assenta-se na análise da configuração subjetiva de professores que continuam e permanecem "vivos" no cotidiano escolar, apesar dos desafios institucionais, sociais, políticos, econômicos, culturais, etc., e do convívio diário com colegas que se encontram desanimados e desesperançosos com a profissão que escolheram. Assim, é nesse contexto de tensão, posicionamento, confronto e reflexão que entendemos que um professor que assume efetivamente com comprometimento a profissão da docência, pode ser considerado enquanto sujeito da sua ação, pois, apesar das adversidades do contexto, busca espaços e possibilidades para sua atuação. 
Frente a isso, na perspectiva de organizar o processo investigativo com foco no problema apresentado, buscamos alcançar o objetivo geral de analisar a constituição subjetiva do professor que se configura enquanto sujeito da sua ação no espaço do seu trabalho educativo. Esse objetivo foi desmembrado nos seguintes objetivos específicos:

- compreender as concepções que subjazem a prática pedagógica do professor e configuram a sua ação;

- explicar a produção subjetiva do professor em relação a demandas e desafios das diferentes situações cotidianas vividas na sala de aula e na escola;

- identificar expressões subjetivas que participam da configuração subjetiva do professor na sua ação docente.

Dessa maneira, realizamos a nossa pesquisa em uma escola pública de Ensino Médio, em Palmas - TO, na qual acompanhamos um grupo de docentes e selecionamos o caso de um professor para análise e aprofundamento da sua constituição subjetiva. Apesar da estrutura sequencial apresentada a seguir em relação à maneira como sistematizamos esse documento, é importante destacar que o percurso trilhado durante o processo investigativo, constituiu-se por um movimento dinâmico de questionamentos, reflexões, dúvidas, elaborações e reelaborações, construindo processualmente uma lógica configuracional sobre o problema que pesquisamos. González Rey (2002), explica que

A lógica configuracional é um processo que não tem só caráter lógico, como a indução e a dedução, que são formas lógicas de seguir duas realidades de naturezas diferentes: a empírica e a proposição conceitual. A lógica configuracional coloca 0 pesquisador no centro do processo produtivo e se refere aos diferentes processos de relação do pesquisador com 0 problema pesquisado. A forma como esses processos se articulam entre si na produção do conhecimento depende muito do problema a estudar, assim como do contexto em que é estudado. A lógica configuracional está orientada para definir os complexos processos intelectuais envolvidos no desenvolvimento do conhecimento sobre a subjetividade. ( $p$. 127) 
Assim, apresentamos ao leitor a maneira como estruturamos a sistematização da pesquisa realizada:

- o primeiro capítulo traz uma discussão teórica sobre o percurso histórico da profissão docente articulando-o com a constituição subjetiva dos professores. Além disso, elaboramos uma discussão epistemológica sobre o conceito de sujeito, destacando o pressuposto teórico que assumimos na nossa pesquisa, a Teoria da Subjetividade, de González Rey (1997, 2004a, 2005a, 2005b, 2011b);

- no segundo capítulo apresentamos uma revisão de literatura com pesquisas realizadas nos últimos dez anos sobre o professor na perspectiva da subjetividade;

- o terceiro capítulo apresenta a opção epistemológica e metodológica que adotamos, a Epistemologia Qualitativa (GONZÁLEZ REY, 1997, 2002, 2005a, 2010, 2014a), e descreve o percurso metodológico que construímos na perspectiva do problema de pesquisa e dos objetivos propostos para a nossa investigação;

- o quarto capítulo apresenta a construção interpretativa das informações da pesquisa, a qual se divide em duas partes: a apresentação do contexto escolar no qual realizamos os procedimentos empíricos; e o estudo de caso de um professor que nos possibilitou compreender a complexa constituição da sua subjetividade nos seus movimentos enquanto sujeito na conjuntura do cotidiano escolar;

- por fim, no quinto capítulo, de maneira articulada com a construção interpretativa, apresentamos uma produção teórica conclusiva sobre elementos subjetivos que configuram o professor enquanto sujeito da sua ação docente, e finalizamos com as considerações finais. 
1 DISCUSSÃO TEÓRICA 


\section{DISCUSSÃO TEÓRICA}

Apresentamos nesse capítulo a discussão teórica que fundamenta a nossa pesquisa, dividindo-a em duas partes. Começamos com uma abordagem sobre o percurso histórico da profissão docente no nosso país, articulando com a constituição da subjetividade dos professores enquanto profissionais que atuam em uma área complexa e desafiadora. Em seguida apresentamos uma discussão teórica e epistemológica sobre o eixo que transversaliza a nossa pesquisa, os conceitos de sujeito e subjetividade, discorrendo sobre a opção teórica que assumimos como referencial.

\subsection{A história da profissão da docência e a constituição subjetiva do professor: tecendo reflexões sobre a trama de dois processos complexos}

O professor vive atualmente um momento de crise no exercício da sua profissão. A sociedade contemporânea situa-se em um momento histórico marcado por intensas mudanças, as quais têm transformado a maneira de ser, pensar, sentir e viver das pessoas. Tal processo adentra o espaço/tempo do encontro cotidiano entre docentes e alunos nas escolas, provocando discussões e reflexões sobre o papel do professor. Apesar das mudanças que aconteceram no decorrer da história, uma questão permanece ainda hoje e transversaliza as diferentes épocas: a centralidade da função do professor como profissional que trabalha com a socialização dos conhecimentos historicamente elaborados e sistematizados pela humanidade, situando-os frente aos desafios do contexto social (NÓVOA, 1995; COSTA, M. V., 2007; VEIGA-NETO, 2007; BARBIERI, 2011; LIBÂNEO, 2012). 
Nessa perspectiva, destacamos a importância do estudo da história da docência para a compreensão do professor, pois esse profissional constitui-se subjetivamente pela sua história de vida, pelas vivências do seu momento atual e também pelo legado das situações e dos fatos que aconteceram e deixaram suas marcas na profissão que escolheu. Além disso, esse processo nos ajuda a entender como chegamos ao atual contexto da docência, compreendendo que a função social da profissão articula-se com as demandas da sociedade em cada período.

Assim, partindo dessas reflexões iniciais, propomos uma discussão em torno dos seguintes enfoques: uma retomada histórica sobre as principais mudanças no papel do professor e na função da escola considerando as demandas da sociedade em cada época; e uma discussão sobre a constituição subjetiva do professor na sua atuação profissional considerando a indissociabilidade entre a história da profissão e a sua subjetividade.

\subsubsection{Retomando a história da docência: uma trajetória que constitui subjetivamente os professores}

No percurso histórico da educação brasileira ocorreram momentos de tensões, contradições, rupturas e permanências nos acontecimentos, nas decisões e nos encaminhamentos, fazendo-nos chegar ao século XXI com o complexo contexto profissional em que atuam os professores. Ao retomar essa trajetória constatamos a história de uma educação escolar que privilegiou o acesso aos filhos da elite, buscando prepará-los para assumirem o comando político e econômico do país. Esse processo teve início já com os jesuítas, quando, no Período Colonial (1500 1822), a educação escolar se caracterizou pela dualidade: a educação religiosa e catequizadora para os índios, e a educação elitizada para os filhos da burguesia emergente da época (ROSÁRIO; SILVA, 2004). Tal situação 
aconteceu situada em um momento histórico em que a sociedade era prioritariamente rural e a população trabalhava com demandas agrícolas, sendo necessária apenas para poucos a aprendizagem da leitura, da escrita, do cálculo e dos conhecimentos escolares. Nesse período a docência era exercida inicialmente pelos padres, e posteriormente também por homens leigos, selecionados pela Companhia de Jesus, que atendiam aos requisitos necessários para trabalhar as orientações educacionais descritas na Ratio Studiorum, o documento norteador do currículo da época (SAVIANI, 2011).

Com a expulsão dos jesuítas em 1759, a educação na Colônia passou a ser orientada pelas diretrizes educacionais de Marquês de Pombal, que implantou o sistema de aulas régias em todo o território de Portugal e nos seus domínios. Conforme Saviani (2011, p. 108), as aulas régias "eram aulas avulsas, [...] os alunos podiam frequentar umas ou outras indiferentemente, pois, além de avulsas, eram isoladas, isto é, sem articulação entre si”. Essa proposta trouxe sérias consequências para a educação no Brasil, pois provocou uma ruptura em relação à organização do sistema educacional em funcionamento até então. Um dos problemas enfrentados foi a falta de profissionais para trabalhar com o sistema das aulas régias, pois a maioria dos docentes até essa época eram os padres da Companhia de Jesus. Como esses profissionais não estavam mais na Colônia, as poucas pessoas que assumiram esse trabalho foram membros de outras ordens religiosas, capelães de engenho e alguns mestres-escola (RABELO, 2010). Outro problema foi a escassez de verbas, pois o Subsídio Literário e o Erário Régio, impostos criados para atender as demandas com a instrução em Portugal e nos seus domínios, eram insuficientes para suprir as necessidades das escolas e o pagamento dos salários dos professores (SAVIANI, 2011).

O trabalho de Marquês de Pombal seguiu até 1777, momento em que foi interrompido em virtude de mudanças no cenário político da época, por ocasião da morte de D. José I, rei de Portugal. O reinado foi assumido por sua filha, Da . Maria I, que iniciou uma nova fase de reformas no desenvolvimento econômico de Portugal com incentivos à indústria e ao comércio. Em contrapartida, seu governo implementou poucas mudanças no âmbito 
educativo, dando continuidade ao sistema das aulas régias. Tais fatos repercutiram no cenário da Colônia somente após algumas décadas quando, em 1808, com a chegada da família real, o contexto era outro tendo em vista o processo de transição para a independência e a necessidade da organização de outra estrutura jurídico-administrativa para o novo país. Esse contexto trouxe mudanças também no sistema educacional, que passou a estruturar o ensino secundário para a formação dos filhos da elite, o qual seguia um currículo nos moldes europeus (ZOTTI, 2002).

Convém destacar que desde o período das reformas pombalinas, passando pelo Período Imperial (1822 - 1889) e até o início do Período Republicano (1889), a dualidade na função social da escola teve continuidade, pois, apesar das mudanças que aconteceram na sociedade, a organização econômica do país continuava pautada no modelo agroexportador. Nesse contexto, a escolarização continuava sendo importante apenas para os filhos da burguesia e da elite, pois as camadas populares aprendiam as técnicas do seu trabalho na convivência do cotidiano, sendo desnecessários os conhecimentos ensinados pelos professores nas escolas.

Apesar disso, as legislações e as políticas do Período Imperial já sinalizavam a necessidade da escolarização para o povo, conforme apresenta Saviani (2011): a Constituição de 1824 colocava no último artigo da lei que "a instrução primária é gratuita a todos os cidadãos"; em 1827 foi promulgada uma lei que determinava a criação de Escolas de Primeiras Letras em todas as cidades e lugares mais populosos; em 1854 o Decreto $n^{\circ} 1.331-A$ institui um regulamento para o ensino primário e secundário do Município da Corte, estendendo sua jurisdição também para as províncias; em 1879 o Decreto $\mathrm{n}^{\circ}$ 7.247 defendeu a liberdade de ensino para as escolas, propondo alguns aspectos em relação à organização do ensino. Entretanto, as intencionalidades da legislação tiveram pouca efetividade, pois a prioridade de investimentos públicos não era a educação, sendo insuficiente a quantidade de escolas e professores para concretizá-las.

No curso dos acontecimentos do século XIX, a sociedade brasileira viveu uma mudança significativa na organização política, a 
descentralização do poder da igreja para o Estado. Essa situação repercutiu também na educação, destacando-se principalmente a introdução da exigência de uma licença para ensinar, concedida pelo Estado a partir de um processo de seleção de professores. Vasconcellos (2004, p. 66) explica que, "para garantir o controle sobre o corpo docente, o Estado criou uma licença ou uma permissão obrigatória para o exercício da atividade docente, que funcionava como um 'aval' para tornar legítima a atuação, convertendo os professores em agentes culturais e agentes políticos". A preocupação do Estado era com a garantia de que a educação estivesse realmente a serviço dos seus interesses e não mais sob a influência da igreja, pois havia a necessidade de introduzir conhecimentos científicos no currículo, tendo em vista o desenvolvimento econômico, e diminuir a ênfase humanística dos ensinamentos (VILLELA, 2000). Apesar disso, a igreja continuou presente com os grupos religiosos que atuavam na educação escolar, porém com menos força nas decisões políticas e econômicas da sociedade.

Além disso, outro aspecto a destacar em relação à licença para ensinar, refere-se ao fato de que esse processo passou a atribuir um status de maior prestígio social para a profissão, pois os professores passaram a ser funcionários do Estado (VILLELA, 2000). Essa situação é analisada por Nóvoa (1995) como um fato relevante no processo de profissionalização da docência, ou seja, nas questões que fazem com que uma profissão seja reconhecida socialmente. Além disso, esse contexto trouxe também a necessidade da formação do profissional que ensinava, sendo criadas as Escolas Normais, nas quais acontecia a preparação específica para o exercício da docência, situação inexistente até então.

Entretanto, apesar das significativas mudanças que ocorreram, a centralidade da função social da escola e do papel do professor continuava sendo a educação da elite, pois a escola para o povo era escassa e tratada com descaso pelas políticas públicas (VILLELA, 2000). Tal situação começou a se modificar efetivamente somente a partir de outras demandas do contexto social, político e econômico que aconteceram entre o final do século XIX e início do século $\mathrm{XX}$, um período que se constituiu por intensas transformações 
na sociedade e também na profissão da docência, influenciadas principalmente pelo advento da industrialização.

O contexto dessa época se caracterizava por um momento em que o país vivia mudanças nos seus processos econômicos, passando de um país essencialmente rural e agrícola, principalmente de produção cafeeira, para a urbanização e a industrialização, dando início a uma nova fase do período republicano. Além disso, como consequência de problemas vividos nas guerras e revoluções nos países europeus, esse foi um período de intensa imigração desses povos para o Brasil, com significativo impacto no crescimento demográfico, que passou de pouco mais de 14 milhões em 1890 para aproximadamente 36 milhões em 1925 (SAVIANI, 2011).

Essa conjuntura trouxe para os dirigentes do país a preocupação com a preparação da população para realizar funções e tarefas decorrentes da industrialização, a fim de potencializar e garantir o desenvolvimento econômico almejado. De acordo com Saviani (2011), outra vez a escola é uma das instâncias sociais por meio da qual busca-se alcançar os objetivos da sociedade, e o trabalho pedagógico volta-se para atender as necessidades do contexto da época: a alfabetização, inclusive dos jovens e adultos excluídos do processo de escolarização; o ensino de conhecimentos gerais; a aprendizagem de determinadas habilidades técnicas; e o atendimento de uma quantidade maior de alunos, tendo em vista o aumento populacional da sociedade.

Tais demandas sociais, juntamente com o acesso dos intelectuais da época aos conhecimentos produzidos e difundidos principalmente na Europa, marcaram o início do século $\mathbf{X X}$ como um período de mudanças significativas na educação. Uma das questões que passou a ser questionada a partir das décadas de 20 e 30 foi o acesso restrito das camadas populares nas escolas, e o processo excludente da educação advindo dos índices elevados de evasão e repetência dos alunos. Nesse contexto a educação começou a ser destaque nas discussões e propostas em âmbito nacional, processo que foi intensificado com a publicação do Manifesto dos Pioneiros da Educação Nova, em 1932. Esse movimento foi liderado por um grupo de 23 intelectuais influentes na sociedade da época, que atuavam tanto em cargos públicos, 
participando na elaboração de políticas e legislações, quanto na docência em escolas e universidades, realizando pesquisas e publicações. Nesse processo, um dos princípios marcantes nos trabalhos dos integrantes do movimento foi a defesa da escola pública, obrigatória, laica e gratuita, em contraposição à escola católica e elitista da época (SAVIANI, 2011).

Contudo, considerando que a educação é uma prática social situada historicamente, essa mudança de perspectivas não aconteceu ao acaso, e as transformações que ocorreram nos vários setores da sociedade implicaram em modificações significativas na docência, dentre as quais destacamos o processo de feminização do magistério. O processo de industrialização trouxe a necessidade de uma demanda maior de mão-de-obra no setor, um mercado de trabalho que passou a se apresentar como promissor, atraindo também os homens que atuavam nas escolas. Assim, o deslocamento de vários professores para o trabalho nas indústrias e o aumento gradativo do número de alunos nas escolas, impulsionou $\mathrm{O}$ ingresso das mulheres no mercado de trabalho para atuarem na docência (ROSA; SÁ, 2004).

Com isso, o processo de feminização do magistério teve início nesse período, situação que provocou transformações significativas na constituição da profissão. Uma delas refere-se ao seu processo de desvalorização social e salarial, uma situação que já acontecia quando os professores eram homens, mas que se intensificou com a participação das mulheres (RABELO, 2010). Um dos motivos dessa situação se refere ao fato de que a mulher exercia uma atividade profissional que era considerada como uma vocação por ser a extensão das tarefas que realizava no lar, ou seja, o cuidado e a educação de crianças. Outro motivo era que muitas mulheres que ingressavam no magistério, provenientes das Escolas Normais, eram oriundas da classe média, e o seu salário era considerado como uma renda secundária e complementar em relação ao que seus maridos recebiam.

Ao analisar o processo de feminização da docência, Rosa e Sá (2004, p. 3-4) sistematizam as explicações que levaram a esse processo em um conjunto de quatro eixos: 
1․ Eixo: alterações na estrutura da ocupação e no mercado de trabalho, as quais teriam criado novas e melhores oportunidades de trabalho para o homem. [...]

2‥ Eixo: Incremento do processo de escolarização, com o aumento do número de escolas e, sobretudo, da matrícula de meninas. Alterações na organização do trabalho escolar e circulação de novos modelos pedagógicos. [...]

$3^{\circ}$. Eixo: Mudanças nas "mentalidades/representações", as quais aproximaram o oficio do magistério daquilo que há muito vinha sendo produzido e considerado como ocupação feminina: o lar, a casa, as crianças. [...]

4‥ Eixo: Protagonismo feminino na ocupação de um emergente mercado de trabalho. Para as mulheres pobres significava ganhar o pão de cada dia; para as mulheres que tinham condições financeiras melhores a possibilidade de uma atividade fora dos domínios do lar (privado). Para ambas, a possibilidade de conciliar o trabalho em casa com o magistério.

Com isso, podemos inferir que a transição do século XIX para o século $X X$ trouxe mudanças que podem ser consideradas como as mais impactantes na constituição da docência na história do país, uma vez que várias permanecem ainda no atual contexto: saímos de uma perspectiva do professor como sacerdócio - período dos jesuítas - e profissional liberal período pombalino e imperial - para o reconhecimento de uma profissão, situação que se intensificou com a licença para ensinar concedida pelo Estado; avançamos da improvisação do trabalho docente para uma profissão que tem um conjunto de saberes a aprender na preparação para o seu exercício; mudamos de uma profissão essencialmente masculina para um processo de feminização da docência; vivemos um período de séculos em que a profissão dedicou-se a trabalhar prioritariamente com os filhos da elite, para um momento em que a escola ampliou sua atuação para atender também as camadas populares.

Sobre esse último aspecto, com o ingresso das crianças das classes populares, o professor passou a vivenciar um novo problema, os altos índices de evasão e repetência dos alunos. Esse fato aconteceu principalmente porque a escola continuou trabalhando com o mesmo currículo, o qual era 
distante da vida e das necessidades desses alunos. Esse distanciamento provocou um processo de discussão também em relação ao papel do professor, sendo questionada a ênfase na centralidade da sua figura como transmissor de conhecimentos. De acordo com Saviani (2011), com a influência das ideias defendidas pelo Movimento dos Pioneiros da Escola Nova, que trouxe para o país o movimento de renovação pedagógica dos Estados Unidos e da Europa, o professor passou a assumir o papel de facilitador do processo de ensino e aprendizagem. Com isso, seu foco principal passou a ser 0 desenvolvimento de habilidades e de conhecimentos que atendessem os interesses dos alunos. Conforme Zotti (2002, p. 71),

Nessa nova conjuntura, a educação ocupará lugar de destaque, pois a complexidade da sociedade urbano-industrial exigirá que um maior número de pessoas tenham acesso à escola. Esta nova realidade é positiva, visto que pela primeira vez a educação é vista como necessária e pensada como projeto nacional. Por outro lado, o interesse pela educação nacional é marcadamente direcionado para atender ao desenvolvimento econômico-industrial, de acordo com os interesses da minoria privilegiada.

Assim, na base dessas mudanças estava implícita a concepção liberal de sociedade e de educação, por meio da qual se acreditava que a escola seria a possibilidade de transformação das pessoas da sua condição de inferioridade para se tornarem cidadãos esclarecidos e com condição de participação política. Saviani (2011) explica que essa visão da escola como redentora dos problemas da sociedade estava ideologicamente atrelada à necessidade brasileira de uma população que conseguisse se inserir no contexto das mudanças políticas e econômicas da época, visando alcançar um patamar de desenvolvimento compatível com as transformações que aconteciam também em outros países.

Com isso, a escolarização passou a ser compreendida como um meio de ascensão social na perspectiva de melhorias na qualidade de vida, e o país realizou políticas públicas em relação a diferentes frentes de trabalho: a 
escolarização das crianças, na perspectiva da formação de uma nova geração para atender as necessidades do desenvolvimento político e econômico da sociedade; a alfabetização dos jovens e adultos que não frequentaram a escola; a qualificação profissional em áreas técnicas específicas para atender as demandas das indústrias e do comércio emergentes; a seleção, para o ingresso no ensino superior, dos alunos que se destacavam em relação as suas capacidades individuais, tendo em vista "constituir a elite que o país precisa para enfrentar a variedade de problemas postos pela complexidade das sociedades modernas" (SAVIANI, 2011, p. 249).

Com o acesso de mais pessoas às escolas e um trabalho mais intenso com a educação, ainda que insuficiente frente aos problemas decorrentes de um significativo período histórico de descaso, juntamente com as mudanças sociais, econômicas e políticas do início do século XX, tanto no Brasil como em outros países, a população começou a ter uma participação mais atuante na sociedade. Movimentos sociais e sindicais, como por exemplo a UNE - União Nacional dos Estudantes e o CGT - Comando Geral dos Trabalhadores, marcaram os acontecimentos da metade do século $X X$. Contudo, a atuação desses grupos se apresentava como uma ameaça no controle da sociedade, tendo em vista o desenvolvimento econômico crescente no país, momento em que os processos políticos foram assumidos pelos militares, com o advento da ditadura de 1964.

Nesse contexto político, a escola passou a assumir outra função social: ensinar a disciplina, a obediência e a ordem. Saviani (2011) explica que, mesmo que discordassem desse tipo de educação, os professores eram obrigados a ensinar seus alunos nessa perspectiva, e os profissionais que discordavam ou realizavam práticas diferentes sofriam penalizações, chegando até a ser exilados, situação que aconteceu com vários docentes que eram ativistas e participavam de movimentos sociais. Além disso, nesse período intensificou-se o foco na qualificação profissional e a legislação educacional foi modificada, por meio da implementação da Lei 5692/71, para que as escolas adaptassem seus currículos, principalmente nos cursos técnicos e no Ensino Médio, denominado na época como $2^{\circ}$ Grau. De acordo com Zotti (2002, p. 75), 
Nesse contexto, a política educacional será a expressão da dominação burguesa, não só pelo autoritarismo que tomou conta das escolas e universidades, mas pelo conjunto de reformas, pensadas pelos técnicos americanos, a serviço dos interesses econômicos e da manutenção da "ordem" ditatorial. Era necessário alinhar o sistema educacional aos objetivos do Estado capitalista militar e isto significava a subordinação da educação à produção capitalista [...].

Assim, esse período foi marcado pela preocupação com uma maior eficácia do trabalho educacional, buscando-se alcançar mais produtividade não só na economia, mas também no trabalho do professor. Com isso, intensificou-se o trabalho pedagógico tecnicista, em que o planejamento era considerado como o foco central, por meio do qual era possível controlar o trabalho do professor, bem como ter uma maior garantia em relação aos resultados almejados (SAVIANI, 2011).

Essas questões aconteceram sob influência dos princípios do fordismo e do taylorismo, que tinham como foco a organização do trabalho nas escolas, tornando o professor em um profissional que executava tarefas definidas por outros. A divisão social do trabalho, com a separação entre aqueles que pensavam e os que executavam a prática pedagógica, foi uma situação marcante nas escolas. Rangel (2000) explica que articulou-se uma estrutura e um funcionamento escolar tendo em vista operacionalizar tais perspectivas: criaram-se as funções do Supervisor Escolar, para controlar e vigiar o trabalho dos professores, assim como o supervisor das indústrias fazia com os empregados; e do Orientador Educacional, para disciplinar o comportamento dos alunos, tendo em vista manter a ordem nas escolas.

Considerando que esse período histórico estruturava-se sob a égide de um regime de ditadura, sua força estava amparada na imposição e no autoritarismo das decisões, limitando as possibilidades de questionamento e discordância em relação às questões que eram definidas pelas pessoas que estavam no comando político do país. Entretanto, em virtude do contexto econômico e político da década de 1980, o regime ditatorial militar começou a 
enfraquecer e a articulação dos movimentos sociais voltou a acontecer gradativamente, dando início ao período denominado como redemocratização. Essa mudança culminou com o processo das eleições diretas na escolha dos governantes, evidenciando-se uma abertura à participação popular nas decisões da sociedade (SAVIANI, 2011).

Nesse contexto a função disciplinadora da educação também começou a ser questionada, tanto em relação aos professores como aos alunos. Inseridos no clima nacional de debates em defesa da participação popular, os professores e os intelectuais da educação questionavam as funções da Supervisão Escolar e da Orientação Educacional e propunham a sua extinção, uma vez que o seu papel era desnecessário no contexto da redemocratização. Esse processo deu vazão a um movimento desses profissionais, que se organizaram em encontros nacionais para discutir e redefinir o papel dos especialistas no contexto escolar (RANGEL, 2000; SAVIANI, 2011).

Outro questionamento levantado no curso dessas reflexões foi em relação ao papel da escola, passando a ser compreendida como lócus de conscientização, emancipação e transformação das pessoas na perspectiva de uma participação ativa e crítica nas decisões e nos encaminhamentos da sociedade. Nesse contexto, de acordo com Saviani (2011), o papel do professor passou a ser analisado na perspectiva da sua atuação crítica e política, como problematizador da visão de mundo dos alunos, tendo em vista a compreensão das ideologias presentes na vida social.

Entretanto, essas reflexões sobre o papel da escola e do professor se modificaram no decorrer da década de 90 . O fortalecimento dos princípios do neoliberalismo nos encaminhamentos políticos e econômicos da sociedade trouxe para a educação a necessidade da preparação das pessoas para atuarem frente a um contexto de rápidas transformações, de imprevisibilidades e da necessidade de agilidade na solução de problemas. As influências do neoliberalismo trouxeram para o professor a redefinição do seu papel na perspectiva de trabalhar para o desenvolvimento de competências e habilidades, atendendo, portanto, a esse novo contexto social, econômico e 
político. Um dos teóricos influentes nesse contexto foi Perrenoud (1999, 2000), que argumentava sobre a importância do professor como um profissional competente. Apresentava uma lista de competências profissionais necessárias no trabalho pedagógico do professor, a fim de adequar-se frente às mudanças da sociedade neoliberal.

A discussão do enfoque das competências na educação foi tão intensa que o papel político do professor, discutido na década de 1980, enfraqueceu frente às influências do neoliberalismo. Preocupados com essa situação, pesquisadores e teóricos da perspectiva crítica continuaram - e ainda continuam - lutando por suas ideias, mostrando inclusive as intencionalidades ideológicas implícitas no trabalho educacional voltado para o desenvolvimento de competências e a sua relação com as políticas dos organismos internacionais de financiamento da educação (FRIGOTTO; CIAVATTA, 2003; GADOTTI, 2000; LIBÂNEO, 2010, 2012). Considerando que o discurso neoliberal passou a ser incorporado inclusive nos documentos oficiais do país, como por exemplo, nas orientações curriculares da educação básica e superior, parece que houve uma aceitação sem a devida compreensão da sua articulação com os princípios dessa política. Os teóricos da perspectiva crítica destacam a importância da compreensão, por parte do professor, sobre as questões implícitas nessa proposta, a fim de que conheça tais intencionalidades e tenha condições de se posicionar frente às mesmas.

Nessa perspectiva, uma reflexão que buscou articular criticamente a discussão entre os enfoques das décadas de 80 e 90 foi uma proposta de análise dos impactos das políticas neoliberais na proposta curricular da escola buscando alternativas de enfrentamento das suas intencionalidades ideológicas (GALLERT; STÜRMER, 2005). Considerando que essas políticas adentraram a educação com a força de serem assumidas como discurso oficial, ao serem incorporadas nas orientações curriculares nacionais, houve uma tendência a aceitá-las sem questionamento, como se fosse mais um modismo pedagógico.

Frente a isso, as autoras alertam sobre a importância da ousadia de um processo educativo que desafie a aparente irredutibilidade dos pressupostos do neoliberalismo, ao defenderem que "é possível visualizarmos 
um trabalho educativo contra-hegemônico através da construção de competências e habilidades crítico-reflexivas" (GALLERT; STÜRMER, 2005, p. 11). Com isso, destacam que o enfrentamento dessas políticas não se dá por uma resistência no sentido de distanciar-se das suas propostas, pois a realização de uma prática educativa que potencialize nos alunos o desenvolvimento de competências torna-se necessária, a fim de que eles tenham condições de atuar na sociedade. Entretanto, os professores não precisam se render à força ideológica dessa política.

Ao invés disso, é importante que os professores compreendam criticamente as intencionalidades implícitas nessas políticas, a fim de que consigam visualizar as possibilidades de operacionalizar uma prática educativa que assuma princípios ideológicos contrários ao neoliberalismo. Nessa perspectiva, é preciso conhecê-los para saber como trabalhar em outro movimento, instigando nos alunos o desenvolvimento de competências na perspectiva da análise do contexto social, da crítica e da articulação em prol da coletividade. Frente a isso, a proposta educacional seria "o pertinente desenvolvimento do aluno capaz e comprometido com a construção coletiva da dignidade cidadã" (GALLERT; STÜRMER, 2005, p. 14).

Articulada à discussão do trabalho pedagógico voltado ao desenvolvimento de competências, a década de 90 trouxe também outros enfoques desafiadores, como por exemplo, a educação inclusiva e o multicultiralismo, os quais ampliaram a abrangência do trabalho com a educação especial. Diversos movimentos, encontros e documentos internacionais e nacionais formalizaram e enfatizaram a necessidade da adequação do currículo escolar a essa nova perspectiva, evidenciando mais uma demanda para o trabalho do professor. Inseriu-se nesse contexto 0 desafio da realização de uma prática pedagógica que contemplasse a diversidade nos seus vários aspectos, tais como cognitivo, emocional, cultural, social, dentre outros. Entretanto, considerando a educação como uma prática social situada historicamente, essa situação também trouxe suas implicações ideológicas, as quais estavam articuladas com os princípios do contexto neoliberal. 
Sobre esses enfoques, Libâneo (2012) traz uma contribuição importante na perspectiva de analisar que o desafio da inclusão, tal como foi operacionalizado por meio das políticas públicas, evidenciou uma dualidade em relação à maneira como a educação escolar acontece para as diferentes classes sociais. Na prática, as escolas que atendem alunos pertencentes às classes socioeconômicas mais favorecidas têm privilegiado 0 acesso a conhecimentos mais abrangentes e aprofundados, enquanto nas escolas que atendem as classes populares o foco principal é o acolhimento social, ficando relegado a segundo plano o trabalho com os conteúdos, que são estudados de maneira superficial.

A dualidade que 0 autor apresenta difere da que analisamos anteriormente, em que a escola atendia prioritariamente os filhos da elite. Desde o início do século $X X, 0$ acesso à escola tem aumentado significativamente, apesar de ainda haver um significativo contingente populacional com baixa escolarização e também de analfabetos. Ao invés disso, o alerta de Libâneo (2012) refere-se ao fato de que a dualidade do currículo desenvolvido nas escolas acontece com enfoques diferenciados, dependendo da classe social que atende, apesar de o país ter documentos orientadores com diretrizes em relação ao que precisa ser abordado em cada etapa da educação. Nesse sentido, assim como Demo (2000, p. 27), que critica as políticas educacionais que preconizam "que aos pobres cabe escola pobre", também Libâneo (2012) alerta que as escolas públicas, na sua maioria, têm abordado superficialmente os conhecimentos, realizando uma proposta pedagógica que enfatiza o acolhimento social.

Nessa perspectiva, a pobreza da escola pública atualmente não se refere tanto às questões estruturais, pois os investimentos nessa área têm aumentado nos últimos anos possibilitando que o espaço físico e os materiais sejam gradativamente aprimorados. A pobreza, conforme os autores, refere-se ao fato de limitar o acesso aos conhecimentos para as pessoas que mais precisam, fazendo com que novamente aconteça um processo educacional dual e elitista. Nesse sentido, Libâneo (2012, p. 26) destaca que a escola pública precisa rever a sua proposta para que tenha clareza da sua função 
social, ou seja, "a escola é uma das mais importantes instâncias de democratização social e de promoção da inclusão social, desde que atenda à sua tarefa básica: a atividade de aprendizagem dos alunos". Assim, o autor explica que a escola não precisa deixar de trabalhar na perspectiva da inclusão, afinal essa também é uma questão importante. Entretanto, os professores precisam articular suas práticas pedagógicas tendo como foco a aprendizagem dos conhecimentos sistematizados, os quais possibilitam aos alunos melhores condições de compreensão e atuação frente aos desafios da sociedade.

Finalizando as abordagens sobre a trajetória histórica da educação no Brasil incluindo aspectos da profissão da docência, destacamos ainda outra demanda emergente que desafia o trabalho do professor, ou seja, a adequação das práticas pedagógicas com a inserção das tecnologias da informação e da comunicação - TICs. Esse desafio começou na década de 1990 e intensificou-se a partir do início dos anos 2000, quando a inserção das tecnologias digitais e o acesso das pessoas à internet passaram a fazer parte do cotidiano. Vários autores têm se dedicado a essa discussão no intuito de analisar o descompasso que há entre a geração dos alunos e seus professores em relação à utilização das TICs (KENSKI, 2003, 2012; VALENTE, 2010; COSTAS, 2011; TUNES, 2011; SIBILIA, 2012). Eles alertam sobre a urgente necessidade de uma renovação pedagógica não só na utilização dos recursos nas escolas, mas também na compreensão sobre os processos de ensino e aprendizagem, pois a nova geração aprende de maneiras diferentes.

Frente ao exposto, intentamos discorrer nesse texto sobre os principais acontecimentos e circunstâncias do percurso histórico da educação no nosso país, contextualizando com situações que configuram a complexidade do atual momento da docência. Na sequência seguimos com reflexões sobre possíveis relações existentes entre a constituição da subjetividade docente e o processo histórico da profissão. 


\subsubsection{História da docência e constituição subjetiva do professor: que relação há entre essas abordagens?}

Dando continuidade às nossas reflexões, compreendemos que a história da docência se apresenta como um processo constituidor da profissão, mas não determinante. Isso porque as circunstâncias históricas não aconteceram de maneira tranquila e homogênea, mas se constituíram por tensões, conflitos e contradições a partir de interesses políticos e ideológicos divergentes, se tomarmos como referência de análise as relações de poder que tensionaram e tensionam a educação como prática social.

Além disso, discutir as mudanças que aconteceram na função social da escola no decorrer da história traz também a necessidade da discussão sobre o profissional que realizou e realiza esse trabalho, o professor, pois ele participou e participa ativamente da concretização das ações que encaminham os rumos desse processo. Inicialmente convém antecipar e anunciar o referencial teórico da nossa pesquisa, o qual aprofundaremos no próximo tópico desse capítulo, a Teoria da Subjetividade, de González Rey (1997, 2004a, 2005a, 2005b, 2011b).

Assim, a partir dessa lente teórica, compreendemos que há uma relação indissociável entre a história da docência e a constituição subjetiva do professor. Isso porque o contexto atual da profissão decorre do legado construído pelas pessoas que atuaram direta e indiretamente na educação, processo esse que constitui a subjetividade dos professores quando assumem essa profissão. O processo histórico da docência aconteceu - e ainda acontece - a partir da atuação de professores, alunos, pais, gestores, políticos, governantes, sociedade civil organizada, dentre outros, que interviram a partir da sua constituição subjetiva individual e social, a qual se situava cultural e historicamente.

Deste modo, apesar da educação escolar ter uma relação direta com as demandas econômicas e políticas de cada época, conforme mostramos, a prática efetiva da escola sempre esteve permeada por conflitos e 
tensões, pois a constituição subjetiva das pessoas as mobiliza em relação a diferentes manifestações frente aos desafios do cotidiano. Nesse sentido, apesar da definição das políticas públicas acontecer historicamente com a mínima ou inexistente participação dos professores, sua operacionalização ocorre de formas diversas, sem padronização e homogeneidade em relação aos resultados almejados.

Nesse movimento de continuidades, rupturas e contradições, o qual caracteriza o processo histórico da docência, os professores tomam decisões e realizam ações no cotidiano das suas aulas e da escola, que são tanto favoráveis como desfavoráveis em relação às diretrizes norteadoras das políticas e propostas educativas. Os desafios que chegam às escolas a partir de demandas sociais, políticas e econômicas, mobilizam nos professores a produção constante de sentidos subjetivos (GONZÁLEZ REY, 2004a, 2005b) em relação às várias questões que configuram o exercício da docência. Esse processo, que acontece de maneira pouco intencional e consciente, ocorre na articulação indissociável entre a emocionalidade, os posicionamentos e as atitudes que os professores assumem e manifestam no cotidiano.

Frente a isso, compreendemos que o curso da história da docência se constitui entre a trama complexa da subjetividade individual e social (GONZÁLEZ REY, 2004a, 2005b) dos professores que convivem cotidianamente nas escolas, com a trama igualmente complexa do contexto social, econômico, político, cultural do momento histórico do seu tempo. Nessa perspectiva, os fatos e as circunstâncias gerais da história precisam ser compreendidos com um olhar mais apurado, que se volta para as relações microssociais do cotidiano da escola, pois é ali que as situações efetivamente acontecem. Considerando que somos seres histórico-culturais (VIGOTSKI, 1998), constituídos subjetivamente pelas questões da história singular que nos constitui, pelo contexto em que vivemos, pelo legado histórico, social e cultural que herdamos da humanidade, o momento atual de cada um se apresenta como uma rede complexa de múltiplas possibilidades.

Nessa perspectiva, a compreensão dessa relação complexa entre as questões macro e microssociais da educação, evidencia a importância da 
compreensão da trajetória histórica da docência para a compreensão da constituição subjetiva dos professores. Isso porque, ao sermos desafiados a encontrar alternativas frente às circunstâncias do atual contexto, precisamos conhecer o legado histórico dos professores que nos antecederam, pois várias situações do seu momento estão presentes nas nossas falas, ações e decisões, ou seja, são questões que configuram a constituição subjetiva social da docência no nosso século.

Outra reflexão importante nessa perspectiva é a compreensão que os professores precisam ter de que são profissionais que não trabalham de forma neutra. Todas as suas ações, decisões e omissões trazem implícitas intencionalidades ideológicas em relação ao tipo de pessoa, de educação e de sociedade que ajudam a construir. Essa é uma questão que caracteriza a profissão da docência e que constitui subjetivamente os profissionais que realizam esse trabalho na sociedade. Tal situação atribui a esses profissionais um caráter de responsabilidade significativa, pois a sociedade tem diversas expectativas em relação ao seu trabalho.

Portanto, considerando as inúmeras questões que se interpõem, as exigências que se apresentam, as circunstâncias históricas que se entrelaçam com as situações do atual contexto, consideramos que um dos maiores desafios que o professor vive atualmente é ser sujeito da sua ação, assumindo efetivamente as questões que implicam trabalhar em uma profissão que vive um momento de crise em relação à definição da sua função em uma sociedade em constantes transformações. Nessa perspectiva, damos sequência à construção teórica abordando uma discussão sobre as perspectivas teóricas e epistemológicas dos conceitos de sujeito e subjetividade, apresentando a opção que assumimos na nossa pesquisa. 


\subsection{Sujeito e subjetividade: perspectivas teóricas e epistemológicas}

Quando estudamos um conceito nos surpreendemos com as várias nuances de significado que o mesmo assume a partir dos distintos olhares que se debruçam na elaboração de explicações em relação a sua compreensão. Tais explicações não acontecem no vazio, mas estão inseridas em contextos históricos, sociais, políticos e culturais em que os autores se situam. Assim, ao buscarmos compreender a constituição subjetiva do professor enquanto sujeito no seu contexto de atuação profissional, tomamos como ponto de partida a compreensão do conceito de sujeito, assunto que é abordado em várias áreas do conhecimento, como a Filosofia, a Sociologia, a Psicologia, a Antropologia, dentre outras.

Iniciamos nosso percurso com a compreensão etimológica, e encontramos que a palavra sujeito deriva do latim subjectu, sendo definida com os seguintes significados: "subjectu ('posto debaixo'). 1. Súdito. 2. Escravizado, cativo. 3. Obrigado, constrangido, adstrito. 4. Que se sujeita à vontade dos outros; obediente, dócil. 5. Dependente, submetido. [...]" (FERREIRA, 2004, p. 1892). Em outro dicionário encontramos significados semelhantes: "1. Que se sujeitou ao poder do mais forte; súdito. 2. Que se conforma; que se deixa guiar por alguém ou por alguma coisa. 3. Domado, escravizado, cativo; que não tem vontade própria. 4. Dependente, submetido, comprometido a obedecer [...]." (LAROUSSE CULTURAL, 1999, p. 847). Entendemos que essa compreensão do conceito está relacionada com o momento histórico da sociedade medieval, período em que a força física de dominação e poder entre as classes sociais era um fator determinante no papel que cada pessoa assumia no seu contexto. Essa abordagem histórica do conceito é apresentada por Gaulejac (2004/2005) ao explicar que 
Etimologicamente, segundo o dicionário histórico de língua francesa, o termo sujeito vem do latim subjectus [...]. "Sub" marca a posição inferior e "jacere", o sentido de jogar fora. Encontramos o termo no antigo francês sugéer. manter na submissão ou, ainda, sougire que significa submeter pela força das armas ou de outro modo. O termo remete, portanto, inicialmente à idéia de submissão. Ele se aplica a uma pessoa submissa à autoridade de uma outra. Daí vem o uso de sujeito do rei, do senhor que remete ao status de vassalo e de justiciável, portanto, de sujeitado ao poder legal. A sujeição evoca a ação de colocar sob, diante, em seguida de", que encontramos nos termos vizinhos de submissão e de sujeição, isto é, da situação de uma pessoa submetida a uma autoridade coercitiva ou soberana. (p. 73).

As abordagens que o autor apresenta, apesar de situarem-se no contexto francês, coincidem com os significados que encontramos nos dicionários da Língua Portuguesa. Além disso, suas colocações nos fazem refletir sobre como um conceito muda o seu significado no decorrer da história, no processo das transformações que acontecem na sociedade e nas relações entre as pessoas. No período da Idade Média as relações hierárquicas entre as classes sociais eram mais visíveis, sendo que o conceito de sujeito traz essa ideia na sua constituição histórica. A ideia do súdito, da pessoa que obedecia as ordens do seu superior, caracterizou a maneira como aconteciam as relações sociais nesse período histórico da humanidade.

Entretanto, considerando as características da sociedade contemporânea, atualmente o conceito de sujeito sofre alteração e assume outros significados. Apesar das mudanças, a situação de submissão ainda se faz presente, porém de maneiras diferentes em relação ao período da Idade Média. Podemos dizer que a submissão atualmente talvez seja mais sutil, ideológica e simbólica, explicitando questões sociais, culturais, econômicas, políticas, dentre outras. E, nessa perspectiva, atualmente torna-se incoerente dizer que uma pessoa submissa é um sujeito. $O$ adequado, no atual contexto, seria dizer que a pessoa que aceita e assume uma postura de submissão torna-se sujeitada a algo ou a alguém.

Tomando ainda como referência as definições dos dicionários, Ferreira (2004, p. 1892) define sujeito da seguinte maneira: "ser individual, real, 
que se considera como tendo qualidades ou praticando ações". Nesse contexto, a definição do conceito assume uma abordagem paradoxal em relação ao significado etimológico da palavra. Ao analisar esse paradoxo, Tomanik (2009, p. 35) argumenta que "temos, aí, uma primeira contradição: a palavra 'sujeito' pode ser usada tanto para indicar alguém que está submetido a um poder externo, quanto o oposto, alguém capaz de agir de forma independente". Frente a isso, Tomanik afirma ainda que estudar o conceito de sujeito "é penetrar em um território inóspito e tenebroso" (idem, p. 33), pois as divergências de ideias entre os autores constituem uma das características principais dessa discussão teórica.

Outra reflexão importante encontramos em Madeira Coelho (2009) quando, ao analisar diferentes concepções do conceito de sujeito e suas repercussões nas concepções de aprendizagem que norteiam as práticas docentes, argumenta que

\begin{abstract}
Diferentes conjuntos de termos eram/foram/são utilizados na tentativa de captar a complexa peculiaridade que a noção de sujeito encerra. No senso comum, sujeito alinha-se com indivíduo, pessoa, eu. $\mathrm{Na}$ tradição filosófica, encontramos as expressões alma, ser, espírito, que na tradição psicológica se tornam consciência, mente, personalidade, self. Na Pedagogia, reiteradamente aparece complementado pelos verbos que indicam os processos característicos do contexto educacional. Fala-se, assim do sujeito do aprender e do sujeito do ensinar. Independente da tradição que as utiliza, as expressões procuram traduzir uma noção humana específica, em que, evidentemente e de alguma forma, subjetividade e sujeito se implicam. (p. 33, grifos da autora)
\end{abstract}

Frente às várias possibilidades de análise e estudo do conceito de sujeito, a autora nos coloca frente ao desafio da opção epistemológica que precisamos fazer no processo investigativo. É imprescindível explicitar as escolhas teóricas que fundamentam a maneira como compreendemos o nosso problema de pesquisa, abordagem que apresentamos no decorrer desse capítulo. Desse modo, seguindo o percurso do nosso estudo, apresentamos as referências teóricas que assumimos em relação ao conceito de sujeito, 
discutindo inicialmente as contradições, convergências e divergências a partir da crise epistemológica do século XX. Esse século se caracterizou por importantes críticas e reflexões sobre as demarcações do campo científico, constituindo um processo de transição com questionamentos em relação ao paradigma dominante na época.

O processo histórico da Ciência, do século XVI ao XIX, encaminhou-se na perspectiva de consolidar o modelo da racionalidade como paradigma dominante (SANTOS, B. S., 2008). Tal modelo referendou a ciência moderna calcada em princípios de comprovação, verificabilidade, quantificação e generalização dos conhecimentos. Essa perspectiva buscava blindar os conhecimentos científicos inclusive em relação ao próprio pesquisador, pois sua participação deveria ser totalmente imparcial, minimizando e neutralizando suas influências para que os resultados fossem verdadeiros e confiáveis.

Esses princípios faziam parte inicialmente da área das Ciências Naturais, a qual resumia o que era considerado como Ciência até o século XIX. Os demais conhecimentos eram considerados como "formas de conhecimento não científico (e, portanto, irracional) potencialmente perturbadoras e intrusas: o senso comum e as chamadas humanidades ou estudos humanísticos (em que se incluíram, entre outros, os estudos históricos, filológicos, jurídicos, literários, filosóficos e teológicos)" (SANTOS, B. S., 2008, p. 21). Assim, valorizava-se aquilo que poderia ser quantificável e o que apresentava regularidades e ordem, possibilitando a formulação de leis e regras que pudessem ser generalizadas, testadas e validadas por outros cientistas. Tais pressupostos assentavam-se ainda na redução da complexidade, sendo necessário "dividir e classificar para depois poder determinar as relações sistemáticas entre o que se separou" (idem, p. 28).

Inserida nesse contexto, a área das Ciências Sociais, emergente a partir do século XIX, para ser aceita socialmente e validada com o status de científica, fundou-se a partir dos princípios da racionalidade. Nessa perspectiva, seu processo de elaboração do conhecimento assentou-se em procedimentos mecanicistas, deterministas e positivistas (SANTOS, B. S., 2008). Tais procedimentos pautavam-se em circunstâncias como, por 
exemplo: havia uma preocupação centrada na elaboração dos instrumentos de coleta dos dados e nos procedimentos de análise, garantindo a confiabilidade dos resultados e as possibilidades de generalização; a quantificação dos resultados era mais valorizada em relação às reflexões e à produção teórica do pesquisador; a imparcialidade na produção teórica era importante a fim de garantir o distanciamento do pesquisador e a validade dos conhecimentos sistematizados.

Tal situação trouxe sérias consequências para as Ciências Sociais, pois a despersonalização dos conhecimentos em uma área que aborda diretamente as questões humanas e sociais possibilitou apenas uma aproximação parcial dos temas estudados. Os fatos, as situações e os problemas analisados abordavam dimensões externas, observáveis e mensuráveis, sendo desconsiderados os aspectos culturais, sociais e subjetivos, pois eram imprevisíveis, complexos e inviabilizavam a objetividade dos conhecimentos científicos da época. Assim, a exigência da neutralidade científica do pesquisador fez com que a Ciência se constituísse como uma ciência sem sujeito. Conforme argumentam González Rey e Mitjáns Martinéz (2016, p. 6),

La visión de una ciencia objetiva, natural, empírica e instrumental llevó a la emergencia del positivismo en el siglo XIX. Este fue el resultado de un proceso que, gradualmente, llevó a una visión única de ciencia que, regida por principios universales, sacralizó e ideologizó el carácter empírico, instrumental y objetivo de la empresa científica. En el plano ontológico, tal concepción representó uma negación radical de la subjetividad que, implícitamente, pasó a ser asociada con lo imperfecto de la condición humana. Se fue desarrollando una representación de hombre exitoso que integró muchos de los puntos débiles del eufemismo occidental del progreso. Esto es, el carácter machista, frío, calculador, objetivo, capaz de dominar sus emociones, como los atributos que debían integrar a esse hombre de éxito. De esta manera, la ciencia fue despojada de su carácter humano y la subjetividad fue excluida de todos los domínios institucionales occidentales. 
Entretanto, a história é um processo vivo e em constante movimento. Além disso, a história da Ciência também é humana, isto é, os cientistas são seres humanos que vivem, sentem, pensam e sistematizam suas teorias imbricadas na constituição da sua subjetividade. Seu envolvimento com os temas que elegem e selecionam para a realização das suas pesquisas não acontece por acaso, mas inserido no contexto da sua emocionalidade e dos seus interesses pessoais e sociais. Entendemos os processos históricos da Ciência nessa perspectiva fundamentados também em González Rey (2004a) quando argumenta que

[...] As posições racionais do ser humano são, na realidade, produções de sentido ${ }^{1}$, na medida em que se organizam sobre a base dos interesses e necessidades relacionados aos contextos desde os quais atua, e a partir de suas histórias nesses contextos. Isso situa no centro da potencialidade mobilizadora da razão uma emocionalidade comprometida com uma história e com uns valores que não são iguais para cada nação, grupo social, família ou pessoa que se situam em culturas diferentes. A razão está subordinada a uma produção histórica de sentidos e não ao contrário. (p. 130)

Assim, os movimentos da história científica não são lineares e imparciais, mas são contraditórios, complexos, subjetivos e desafiadores devido aos diversos posicionamentos que os cientistas assumem frente às ideias que defendem. Com isso, imbuídos desse processo humano e social, os princípios da racionalidade foram questionados pelos próprios pesquisadores da área das Ciências Naturais, e o paradigma dominante começou a atravessar uma profunda crise. Conforme B. S. Santos (2008), esse movimento científico aconteceu em virtude das seguintes condições sociais e teóricas decorrentes das descobertas que esses pesquisadores defenderam:

\footnotetext{
${ }^{1} \mathrm{O}$ conceito de produção de sentido subjetivo será abordado mais adiante, no decorrer desse capítulo. Antecipamos brevemente sua explicação com uma citação do autor: "Os sentidos subjetivos representam complexas combinações de emoções e de processos simbólicos que estão associados a diferentes esferas e momentos da vida e que podem estar envolvidos em configurações subjetivas distintas. Os sentidos são capazes de reorganizar-se diante dos tipos de emoções e de processos simbólicos produzidos pelo sujeito em uma atividade concreta" (GONZÁLEZ REY, 2005a, p. 41).
} 
- como primeira condição, explica que "[...] a identificação dos limites, das insuficiências estruturais do paradigma científico moderno é o resultado do grande avanço no conhecimento que ele propiciou. $O$ aprofundamento do conhecimento permitiu ver a fragilidade dos pilares em que se funda" (idem, $p$. 41). Nessa abordagem o autor destaca a importância do físico Albert Einstein em relação a questionar o rigor das leis de Newton e defender a ideia da relatividade e da simultaneidade de acontecimentos observados e pesquisados pelos cientistas;

- a segunda condição teórica apresentada por B. S. Santos (2008) foram as ideias defendidas pela mecânica quântica, destacando que os físicos "Heisenberg e Bohr demonstram que não é possível observar ou medir um objeto sem interferir nele, sem o alterar" (p. 43), inserindo os princípios da incerteza e da probabilidade como pilares do conhecimento científico;

- a terceira condição da crise do paradigma dominante foram as investigações do matemático Kurt Gödel que defendeu "o teorema da incompletude (ou do não complemento) e os teoremas sobre a impossibilidade, em certas circunstâncias, de encontrar dentro de um sistema formal a prova de sua consistência", mostrando que, "mesmo seguindo à risca as regras da lógica matemática, é possível formular proposições indecidíveis, proposições que se não podem demonstrar nem refutar" (SANTOS, B. S., 2008, p. 45);

- e a quarta condição B. S. Santos (2008) situa nas investigações do físico-químico llya Prigogine, que defendeu a teoria das estruturas dissipativas e o princípio da ordem através de flutuações em sistemas abertos, argumentando que

A importância desta teoria está na nova concepção da matéria e da natureza que propõe, uma concepção dificilmente compaginável com a que herdamos da física clássica. Em vez da eternidade, a história; em vez do mecanicismo, a interpenetração, a espontaneidade, a auto-organização; em vez da reversibilidade, a irreversibilidade e a evolução; em vez da ordem, a desordem; em vez da necessidade, a criatividade e $o$ acidente (SANTOS, B. S., 2008, p. 48). 
Dessa maneira, a crise no paradigma da racionalidade trouxe a inserção do sujeito e da subjetividade com caráter de cientificidade nas inúmeras possibilidades da sua contribuição frente à compreensão de problemas complexos. Nessa perspectiva, entendemos que um dos questionamentos que emerge como possibilidade investigativa é o próprio conceito de sujeito que, inserido na trama complexa do percurso histórico da Ciência, foi abordado a partir de diferentes enfoques. Esse percurso histórico conceitual é analisado na trajetória da Psicologia em várias publicações de González Rey (1997, 2004a, 2005b, 2009a, 2011a, 2013a), concluindo que

La idea de sujeto racional, transparente y consciente, que tanto peso tuvo en la cultura romántica y humanista, entró, así, en crisis. Sin embargo, la crítica a las posiciones individualistas en relación al sujeto, en lugar de conducir a nuevas formas de pensarlo, lo excluyeron, primero en nombre de la estructura y después, con el advenimiento del post-estructuralismo, en nombre de las prácticas discursivas. Sujeto, subjetividad, conciencia, o cualquier proceso que apuntara al carácter generador de la persona, quedaron excluidos del repertorio de las ciencias sociales. (idem, 2013a, p. 23)

Nessa perspectiva, a mudança no enfoque do conceito de sujeito, como possibilidade de compreendê-lo acerca do processo de vir a ser, valorizando o caráter gerador do próprio sujeito, trouxe uma contribuição importante no percurso dessa construção teórica. Compreender que ser sujeito não é algo dado, ou algo explicado de maneira generalizada e padronizada, trouxe o legado da construção teórica de autores que se dedicaram a analisar a temática a partir da singularidade e dos contextos sociais e culturais implicados nesse processo.

Um dos autores que defende essa perspectiva é o sociólogo e historiador francês Alain Touraine (1925 -) que, a partir dos seus estudos sobre a sociedade pós-industrial, busca substituir uma sociologia do sistema social por uma sociologia do ator (TOURAINE, 1998, 2004). Discute que, a partir das 
transformações provocadas pela modernidade, com 0 desenvolvimento capitalista e a revolução industrial, as pessoas se tornaram mais individualistas no sentido de traçar o seu "caminho individual, isto é, combinando [sua] participação no mundo planetário das técnicas, dos mercados e do consumo, com a defesa das orientações culturais recebidas ou criadas" (TOURAINE; KHOSROKHAVAR, 2004, p. 9)2.

Nessa perspectiva, no processo de construção da sua teoria, na década de 1970 defendia o conceito de ator social, como uma crítica à análise da sociedade do indivíduo. Entretanto, a partir de 1990 passou a compreender que havia a necessidade de discutir sobre o processo intermediário de passagem do indivíduo para o ator social. Foi nesse contexto que incluiu o conceito de sujeito, conforme explica:

O ator social era caracterizado pelo primado absoluto da esfera pública sobre a do privado e também pela inserção do lugar das lutas na primeira esfera, e isso, frequentemente, em detrimento da segunda. Atualmente, a vida privada apresenta uma importância capital para o sujeito: não que se trate para ele de confinar-se nesse local, mas porque lhe é conveniente encontrar uma tradução adequada da vida privada no espaço público. A articulação entre o privado e o público torna-se essencial e dá sentido a novas formas de mobilização social. [...] O sujeito é, por isso mesmo, mais "realista", bem mais "pé no chão" do que o ator social [...], o sujeito está solidamente ancorado na vida cotidiana. Esse aspecto do sujeito, seu enraizamento na vida privada e sua aspiração a dar sentido a essa vida, articulando a experiência privada à pública e, como retorno, lendo o público a partir das referências concretas do privado, é seu traço distintivo. (TOURAINE; KHOSROKHAVAR, 2004, p. 19).

Nessa colocação percebe-se que os argumentos do autor indicam sua crítica em relação a uma leitura da sociedade e dos sujeitos que centraliza o viés da organização política e econômica. Ele busca romper com essa visão

\footnotetext{
${ }^{2}$ Convém explicar que o livro "A busca de si: Diálogo sobre o sujeito" é o registro de diálogos de Khosrokhavar com Touraine sobre a construção teórica em relação ao conceito de sujeito. Assim, a obra apresenta a teoria construída por Touraine, porém na referência bibliográfica os dois autores são citados em virtude de que o livro foi elaborado por ambos.
} 
enfatizando que, na sua discussão sobre o conceito de sujeito, os aspectos políticos e econômicos não são desconsiderados, mas passam a fazer parte da vida privada e não somente da vida pública do cidadão. O sujeito está, então, na articulação entre o público e o privado (TOURAINE, 1998; TOURAINE; KHOSROKHAVAR, 2004). Assim, critica as teorias que centralizam suas explicações sobre o sujeito nas questões de poder e na divisão do trabalho, argumentando que

Nossa capacidade de agir sobre nós e sobre nosso ambiente não cessa de aumentar, para o melhor ou para o pior. As décadas passadas acreditaram nas leis da natureza humana ou naquelas da sociedade e produziram uma caça ao sujeito. Hoje mesmo, procura-se por todos os lados convencer-nos de que o sistema econômico internacional tem uma lógica irresistível. Afirmamos o contrário: os fatores não-econômicos, em particular a inovação e a educação, têm efeitos bastante favoráveis para o crescimento. Da mesma maneira, as causas das crises econômicas regionais são muito mais internas, sociais e políticas do que exteriores. As margens de escolha aumentam. Temos a necessidade de uma sociologia da ação, como eu dizia no início de minha vida profissional, de uma sociologia do sujeito, digo hoje, dando muito mais importância à ética do que à política; uma política que se vê, por outro lado, ultrapassada pela economia globalizada e pela irrupção de técnicas. (TOURAINE; KHOSROKHAVAR, 2004, p. 12-13).

Ao apresentar discussões nessa perspectiva, Touraine destaca os movimentos contraditórios e complexos da constituição do sujeito, levantando questionamentos como: "a grande questão não é mais: 'como funciona uma sociedade?'; mas sim: como um indivíduo e/ou um grupo podem criar, manter e transformar sua singularidade, ao mesmo tempo em que guardam valores universalistas?" (TOURAINE; KHOSROKHAVAR, 2004, p. 28). E questiona adiante: "[...] como sobreviver pessoalmente num mundo que destrói a individualidade, a autonomia?" (p. 35). Tais argumentos evidenciam uma busca pela compreensão do sujeito na relação indissociável entre circunstâncias individuais e sociais, as quais estão constantemente imbricadas, constituindo 0 sujeito e sendo por ele constituídas. Com isso, compreende que o processo de tornar-se sujeito acontece por meio da 
[...] capacidade de refletir sobre si próprio para poder reconhecer-se na vida que cada um leva, que nos é imposta pelo nascimento, pelo desemprego, pela televisão, pelos poderes, etc. Poder reencontrar-se na vida, fazendo de modo que minha vida seja a minha vida. (grifo do autor) (TOURAINE; KHOSROKHAVAR, 2004, p. 36).

A partir desses argumentos inferimos que Touraine enfatiza a importância e necessidade de liberdade do sujeito em relação à organização social, tendo condição de refletir sobre si com autonomia, apesar de estar inserido em um sistema que pressiona e impõe diversas ideologias. Assim, o que Touraine (1998; 2004) mostra no processo de construção da sua teoria, é que antes defendia somente o conceito de ator social, porém percebeu uma incompletude nessa abordagem que precisava de uma explicação sobre o a priori desse momento: "Num primeiro momento, lutei durante 30 anos para defender a ideia do ator, mas hoje me parece muito mais pertinente insistir na ideia de sujeito, pois só é ator quem se constitui como sujeito de sua própria vida e de seus atos" (TOURAINE; KHOSROKHAVAR, 2004, p. 107). Assim, entendemos que o autor avança em relação ao conceito de sujeito, entretanto não alcança a compreensão do potencial do caráter gerador da subjetividade.

Compreendemos que a abordagem teórica desse enfoque se apresenta como uma das importantes contribuições do psicólogo cubano González Rey (1949-), que desenvolve a Teoria da Subjetividade desde a década de 70. Assim, esse autor aprofunda a compreensão do conceito de sujeito na perspectiva das produções subjetivas que possibilitam o processo de constituir-se enquanto sujeito no percurso da vida social de cada pessoa. Partindo da crítica e do questionamento acerca da visão positivista das pesquisas e dos estudos em Psicologia, o autor se posiciona assumindo como alicerces as abordagens da complexidade e da perspectiva histórico-cultural. Suas bases teóricas e fontes de inspiração assentam-se principalmente na Teoria da Complexidade (MORIN, 1998, 2005; MORIN; LE MOIGNE, 1999) e na psicologia soviética, com destaque para os trabalhos de Vigotsky (1983, 1987, 1997, 1998, 2003), além de "contribuições de outros autores soviéticos 
de diferentes tendências teóricas, tais como: Bozhovich, Abuljanova, Chudnovsky, Nepomniachaiya, Bratus, Asmolov, entre outros" (ROSSATO; MARTINS; MITJÁNS MARTÍNEZ, 2014, p. 38).

Entender o sujeito e a subjetividade a partir dessa abordagem teórica implica rescindir-se de dicotomias como razão e emoção, social e individual, consciente e inconsciente. Implica romper com o paradigma dominante da racionalidade, da fragmentação e do determinismo, a fim de analisar e compreender as pessoas e os contextos sociais em que convivem a partir do processual, do indissociável, do provisório, do imprevisível e do contraditório (GONZÁLEZ REY, 2005b, 2011a, 2013a). Além disso, implica ainda compreender que as pessoas constituem-se no curso da sua história de vida, nas relações e interrelações com o outro, com a cultura, o contexto social, político, econômico da sua época e dos seus espaços sociais de convivência.

Partindo de tais pressupostos, González Rey (2004b, p. 22) argumenta que

O sujeito é um momento inseparável de uma teoria da subjetividade em uma perspectiva histórico-cultural, pois sem sujeito a subjetividade permaneceria a-sujeitada e substanciada em um plano intrapsíquico, o que não permitiria superar o essencialismo ao qual esteve associada a representação de subjetividade em algumas tendências do pensamento moderno, e que tanto dificultam, ainda hoje, o uso do termo.

Suas proposições evidenciam a necessidade de repensar esse conceito, superando os determinismos, os padrões apriorísticos e o transcendentalismo, para considerar as possibilidades e os desafios dos momentos reais e concretos vividos por cada pessoa, situações nas quais constituem e expressam a sua subjetividade. Nessa perspectiva, González Rey (2005b) sustenta sua teorização apresentando os diferentes momentos como o conceito de sujeito foi abordado na história da Psicologia, alguns dos quais já mencionamos no decorrer desse capítulo. 
Inicialmente apresenta a influência das tendências filosóficas da modernidade, fundamentadas principalmente no racionalismo cartesiano, que firmaram a ideia do sujeito da razão, produtor de verdades absolutas e com capacidade de dominar o mundo e a si mesmo. Como oposição a essa ideia, a fenomenologia defendeu a ideia do sujeito transcendental, que "terminou por separar o homem da história e do seu mundo real" (GONZÁLEZ REY, 2005b, p. 221), pois teve como foco central a compreensão do homem a partir dele próprio, desconsiderando o contexto no qual estava inserido. Discordando dessas duas abordagens, o movimento pós-estruturalista criticou 0 racionalismo e o essencialismo, desenvolvendo uma psicologia dessubjetivada e sem sujeito, "que se tem caracterizado mais pelo empirismo de suas construções e pelo caráter metafísico de seus princípios universais, que pelo reconhecimento da processualidade" (idem, p. 222).

Como contraponto a essas vertentes, González Rey (2005b, p. 222) defende a importante contribuição do marxismo na elaboração das teorias psicológicas, pois,

[...] pela primeira vez, representa no pensamento filosófico o caráter histórico e social do homem, que supunha o trânsito de um sujeito universal, fechado dentro de um conjunto de categorias metafísicas, para um sujeito concreto, que mostra em sua condição atual a síntese de sua história social, não como acumulação, mas como expressão de uma nova condição.

Assim, assume como pressuposto epistemológico para o estudo da subjetividade a perspectiva histórico-cultural, fundamentada no marxismo, principalmente a psicologia soviética com os trabalhos de Vigostsky. A psique passa a ser analisada como um sistema complexo e em constante processo de desenvolvimento, centrando suas reflexões no sujeito, na sua história de vida e nos contextos sociais em que vive.

Nessa perspectiva, depreende-se, na compreensão do conceito de sujeito, que os momentos de imprevisibilidade, contradição, 
processualidade, tensão, conflito, etc., são circunstâncias imbricadas na trama complexa das relações que se estabelecem no cotidiano, tecendo o processo de constituição subjetiva singular e único como cada pessoa vive e se posiciona perante os desafios que se interpõem na sua vida. Tanto as situações complexas como as cotidianas demandam algum tipo de manifestação, sendo a expressão da constituição subjetiva singular em cada pessoa, constituinte e constituidora da maneira como as circunstâncias são vividas pelos grupos sociais e pelas pessoas. Considerando a complexidade como acontecem tais relações, González Rey (2004a, p. 149) argumenta que

O sujeito representa a possibilidade de particularização dentro dos processos normativos de toda a sociedade e, nesse sentido, está associado ao caráter processual e a tensão que caracterizam a vida social, marcando um processo suscetível de mudanças permanentes e inesperadas, e não um sistema submetido a leis supraindividuais que decidem o destino da história.

Na compreensão do autor, a relação entre o sujeito, a sociedade e o curso da história precisa ser compreendida a partir de uma análise que se aproxima da vida cotidiana, da imprevisibilidade das tensões e mudanças que ocorrem nas relações entre as pessoas a partir das situações do seu contexto. Defende que o sujeito é um ser humano ativo, situado no seu momento histórico e no espaço em que vive, atuando com o seu pensar, sentir, refletir e agir, interferindo na sociedade e sendo por ela provocado, em um movimento de recursividade. Reafirma esse pressuposto ao afirmar que

Reconhecer a capacidade de tensão e ruptura do sujeito individual não significa libertá-lo de seu caráter social em seu papel de sujeito subjetivado. Pois seu caráter subjetivo, embora se desenvolva em vários campos de ação, se expressa como processo permanentemente que entra em contradição com a estabilidade relativa que resulta de sua configuração histórica. (GONZÁLEZ REY, 2004a, p. 154). 
Desse modo, compreender o sujeito significa aproximar-se do universo da sua singularidade, na indissociabilidade com o contexto social. $O$ sujeito não toma decisões isoladamente, mas parte de uma leitura e de um entendimento do seu momento histórico e do seu contexto social. Suas ações repercutem no seu entorno e provocam mudanças no curso das situações vividas nos coletivos em que atua, assim como as intervenções dos outros também modificam, de forma dinâmica e processual, a constituição da sua subjetividade.

Nesse processo constante e ininterrupto de relações sociais que constitui o ser humano, González Rey (2010, p. 11) argumenta que é sujeito

[...] a pessoa ativamente envolvida na delimitação e desenvolvimento de espaços pessoais dentro das atividades sociais que desenvolve. A pessoa como sujeito é capaz de se posicionar e de se confrontar a partir de seus projetos, pontos de vista e reflexões pessoais, sempre que esses processos representem produções de sentido subjetivo. O sujeito existe na tensão com o estabelecido.

Considerando que o cotidiano da vida se configura por momentos diferentes, vividos tanto com situações rotineiras, como com desafios, tensões e problemas que requerem posicionamentos com uma intensidade maior ou menor de emocionalidade, a colocação do autor nos permite inferir que ser sujeito é algo vivido de forma inconstante pelas pessoas. Ou seja, as pessoas não são compreendidas como sujeito em todos os momentos da sua vida, pois nem sempre as situações vividas demandam posicionamentos que implicam sua emergência com posturas mais ativas.

Além disso, até mesmo as circunstâncias em que o confronto com ideais e projetos pessoais se faz presente, pode provocar ou não a emergência do sujeito. Nesse processo, a pessoa pode "subordinar-se às várias ordens que caracterizam a institucionalização dos espaços em que se desenvolve, ou gerar alternativas que Ihes permitam opções singulares dentro de sua socialização nesses espaços" (GONZÁLEZ REY, 2004a, p. 149), situação relacionada com 
a maneira como se constitui a sua subjetividade. Tais manifestações podem acontecer quando a situação vivida provoca diferentes maneiras de ser, pensar, sentir e agir, gerando a produção de sentidos subjetivos, num movimento de colocar-se ou não como sujeito frente aos desafios do cotidiano.

A construção teórica desses argumentos do autor indica ainda que o sujeito, entendido como a pessoa ativa nos seus espaços de relação social, pode ser tanto aquele que evidencia explicitamente sua participação no plano da ação, como também aquele que é menos evidente em um grupo social. Isso porque há pessoas que são mais reservadas em momentos coletivos, mas que, em pequenos grupos ou mesmo individualmente, têm iniciativa e articulação para resolver as demandas cotidianas da sua vida. Além disso, considerando que existem espaços de relações sociais repressivas, isso não significa que neles não haja a emergência do sujeito, pois esse processo acontece na processualidade dos sentidos subjetivos que cada pessoa produz de maneira articulada com os contextos sociais da sua convivência. Sobre essa perspectiva, o autor argumenta que

El sujeto puede no expresar procesos alternativos de subjetvación en suas prácticas cotidianas, pues entre los propios procesos de subjetivación y la práctica no se da una relación directa e inmediata; sin embargo, puede estar madurando, a nivel subjetivo, nuevas formas de acción dentro de los espacios sociales en que actúa, cuya expresión puede ser sorpresiva. Por tanto, en nuestra definición sobre la subjetividad destacamos al sujeto como una forma cualitativa diferenciada de la persona, orientada a abrir espacios propios de prácticas y de procesos de subjetivación en los diferentes grupos e instituciones en los que actúa. (GONZÁLEZ REY, 2011a, p. 215).

Depreendemos dessa reflexão que a compreensão de González Rey sobre o conceito de sujeito articula-se de maneira indissociável com a produção de sentidos subjetivos, os quais "[...] constituyen la organización simbólico-emocional que toma la experiencia vivida y se expresan en las más 
diversas manifestaciones humanas, pero nunca se develan en su integridad en ninguna de ellas tomadas por separado" (2011a, p. 208).

Frente ao exposto, compreendemos o quanto González Rey, no desenvolvimento da sua teoria, atribui uma importância significativa ao sujeito, pois sem ele não há produção de sentidos subjetivos. A subjetividade não existe sem o sujeito. Esse sujeito não é um objeto de estudo passivo, mas um ser que participa da sua própria história, que se constitui e é constituidor dos espaços sociais. Sobre isso, o autor argumenta que

Só o sujeito poderá decidir, dentro da complexidade de vivências e processos simbólicos produzidos nos cenários de sentido em que atua, o rumo de suas ações, as quais, desde o momento de sua decisão e durante todo o processo de consecução, se transformam em uma nova rota de produção de sentido. (GONZÁLEZ REY, 2004a, p. 158)

Nessa perspectiva o sujeito assume um papel central, tanto nas questões de ordem individual quanto social, pois a maneira como as situações acontecem no cotidiano dos grupos sociais relaciona-se com a maneira como cada pessoa pensa, vive, sente, se manifesta, decide e encaminha suas ações. Esse processo se apresenta de maneira complexa e dinâmica, pois cada sujeito se constitui de maneira única a partir da sua história de vida.

Esse processo constitutivo do sujeito nos remete à compreensão de alguns conceitos basilares para a construção interpretativa das informações da nossa pesquisa, que apresentaremos nos próximos capítulos, além da discussão teórica apresentada até então. Compreender o professor na perspectiva da constituição da sua subjetividade nos levou a construir hipóteses interpretativas sobre elementos que participavam da sua configuração subjetiva, sobre a qual González Rey (2005a) argumenta o seguinte: 
[...] a categoria de configuração não se define por conteúdos universais, nem por processos únicos de caráter universal, senão que constitui um núcleo dinâmico de organização que se nutre de sentidos subjetivos muito diversos, procedentes de diferentes zonas de experiência social e individual. Precisamente, considero que o valor heurístico desta categoria está em sua elevada flexibilidade, e no fato de representar um elemento que se constitui no funcionamento de um sistema, pois as configurações são um elemento de sentido dentro do comportamento atual de um sistema subjetivo, seja este social ou individual e, ao mesmo tempo, podem alterar sua forma de organização ante a emergência de sentidos e configurações que passam a ser dominantes dentro do momento atual da ação do sistema. (p. 203-4)

Nessa perspectiva, nossa pesquisa não teve a pretensão de abarcar a compreensão da totalidade da configuração subjetiva do professor com quem realizamos o estudo de caso, conforme abordaremos. Isso porque o dinamismo, a fluidez e a flexibilidade da maneira como os sentidos subjetivos são produzidos e organizam-se provisoriamente no sistema da configuração subjetiva nos possibilita compreender parcialmente esse processo. Assim, a compreensão dos sentidos subjetivos enquanto "unidade inseparável dos processos simbólicos e as emoções num mesmo sistema, no qual a presença de um desses elementos evoca o outro, sem que seja absorvido pelo outro" (GONZÁLEZ REY, 2005a, p. 127), se apresenta como um processo complexo no estudo da subjetividade.

Na compreensão desse sistema, convém destacar que há uma relação indissociável entre os sentidos subjetivos e a configuração subjetiva. Os sentidos subjetivos, enquanto unidades simbólico-emocionais, são produzidos, elaborados e reelaborados continuamente pelo sujeito, de maneira consciente e inconsciente, sem que haja uma intencionalidade nesse processo (GONZÁLEZ REY, 2005b). Sua constituição é fluída, dinâmica, imprevisível e provisória, sendo praticamente impossível ao pesquisador precisar exatamente quais são os sentidos subjetivos de um sujeito.

Entretanto, esse processo em constante movimento alcança certa estabilidade na constituição da subjetividade ao configurar-se enquanto núcleos subjetivos, os quais possibilitam a compreensão de produções 
subjetivas do sujeito em relação a certas circunstâncias que emergem no estudo de um caso. Assim, a organização sistêmica e processual desses núcleos nos indica a compreensão da configuração subjetiva, a qual apresenta uma estabilidade temporária e processual (GONZÁLEZ REY, 2005b). Isso porque as circunstâncias da vida social podem provocar processos de mudança nos núcleos subjetivos que a constituem, reconfigurando o sistema subjetivo. González Rey (2005a) explica esse processo argumentando que

\begin{abstract}
As configurações subjetivas seriam as responsáveis pelas formas de organização da subjetividade como sistema, e elas são relativamente estáveis por estarem associadas a uma produção de sentidos subjetivos que antecede o momento atual da ação do sujeito e que pressiona a produção de sentidos de qualquer ação nova em temos da organização do sistema. No entanto, a produção atual de sentidos subjetivos, que caracteriza os diferentes instantes da vida do sujeito dentro de seus diversos campos de atividade, nunca está determinada, a priori, desde a natureza da configuração subjetiva. Toda produção de sentidos subjetivos é o resultado da tensão entre os sentidos que aparecem no percurso da ação do sujeito e os sentidos que antecedem esse momento, a partir das configurações subjetivas implicadas em cada situação concreta dessa ação. (p. 35)
\end{abstract}

Assim, depreendemos da argumentação do autor, que esse processo não acontece de maneira isolada ou somente dentro da estrutura psicológica do sujeito. Ao invés disso, os processos subjetivos acontecem imbricados na relação indissociável entre o social e o individual, pois o sujeito é um ser social, histórico e cultural. Nessa perspectiva, González Rey (2013b) amplia a discussão da sua teoria apresentando os conceitos de subjetividade social e subjetividade individual, os quais se constituem mutuamente em processos contínuos de recursividade, ou seja,

Essa tensão permanente entre o indivíduo e os processos institucionalizados de sua vida social é a que apresentamos em nosso trabalho como a relação entre a subjetividade social e individual, onde uma nunca é externa a outra, emergindo de múltiplas maneiras, uma constituinte da outra, processo que 
acontece de forma singular tanto nos espaços sociais afetados por essas dinâmicas como nas pessoas que compartilham suas práticas no interior desses espaços. (p.182)

A compreensão desses dois conceitos, constituintes e constituidores das pessoas e das relações vividas nos espaços sociais, de maneira processual e recursiva, reafirmam o entendimento do sujeito enquanto ser humano situado no seu contexto social, histórico e cultural. Assim, "a subjetividade individual indica processos e formas de organização da subjetividade que ocorrem nas histórias diferenciadas dos sujeitos individuais. Portanto, ela delimita um espaço de subjetivação que contradiz e de forma permanente se confronta com os espaços sociais de subjetivação" (GONZÁLEZ REY, 2002, p. 141). E a subjetividade social "apresenta-se nas representações sociais, nos mitos, nas crenças, na moral, na sexualidade, nos diferentes espaços em que vivemos etc. e está atravessada pelos discursos e produções de sentido que configuram sua organização subjetiva" (GONZÁLEZ REY, 2005b, p.24).

Nessa perspectiva, podemos afirmar que cada espaço de interação e de atividade humana se constitui por uma subjetividade social específica, pois neles atuam pessoas com subjetividades individuais singulares e únicas, as quais, no convívio com os demais, articulam-se recursivamente. Além disso, a subjetividade social se constitui de maneira diversa também em virtude das razões pelas quais as pessoas se reúnem, pois o mesmo grupo configura-se subjetivamente de maneiras diversas dependendo da situação que, em conjunto, está vivendo. As ações dos sujeitos, em um momento e local concretos, expressam suas experiências anteriores e atuais vividas em outros espaços sociais, evidenciando sua historicidade.

Por fim, concluindo a discussão teórica, destacamos o quanto a compreensão sistêmica dos conceitos que constituem a Teoria da Subjetividade evidencia a complexidade e originalidade da construção desenvolvida por González Rey. Uma teoria aberta e em desenvolvimento, que nos possibilita uma abordagem científica coerente no estudo dos desafios 
vividos pelo professor no contexto educacional do nosso momento histórico, bem como de outros temas complexos.

Tal compreensão evidencia também a complexidade da subjetividade humana, pois a análise superficial da maneira como uma pessoa se posiciona não permite concluir sobre sua emergência enquanto sujeito. Fazse necessário uma análise aprofundada de diversas situações atuais e históricas da vida de uma pessoa, que a constituem no seu momento presente, para que possamos compreender os elementos subjetivos que configuram sua subjetividade, um processo construtivo-interpretativo que demanda a elaboração de processos de inteligibilidade por parte do pesquisador (GONZÁLEZ REY, 1997, 2002, 2010). Portanto, considerando as abordagens apresentadas na discussão teórica, antes de discorrermos sobre o percurso metodológico da nossa pesquisa, apresentamos no próximo capítulo um panorama das principais investigações que encontramos relacionadas ao nosso tema. 
2 REVISÃO DE LITERATURA 


\section{REVISÃO DE LITERATURA}

Considerando as discussões apresentadas no capítulo anterior, delineamos que a opção teórica assumida para a realização da nossa pesquisa é a Teoria da Subjetividade, de González Rey (1997, 2004a, 2005a, 2005b, 2011b), pois concordamos com a abordagem complexa, sistêmica, histórica e cultural como o autor teoriza sobre a subjetividade e o sujeito, argumentando que é sujeito

[...] a pessoa ativamente envolvida na delimitação e desenvolvimento de espaços pessoais dentro das atividades sociais que desenvolve. A pessoa como sujeito é capaz de se posicionar e de se confrontar a partir de seus projetos, pontos de vista e reflexões pessoais, sempre que esses processos representem produções de sentido subjetivo. O sujeito existe na tensão com o estabelecido. (idem, 2010, p. 11)

Partindo dessa premissa, propomos para esse capítulo a apresentação de um breve panorama dos principais trabalhos que encontramos relacionados com o tema da constituição subjetiva do professor. Consideramos que esse mapeamento se apresenta como um momento importante para que o pesquisador se aproxime e conheça as investigações já realizadas na sua área, a fim de que possa contribuir com a ampliação e o aprofundamento dos estudos sobre determinado tema. Assim, elegemos como critérios de busca o levantamento de pesquisas de Mestrado e Doutorado realizadas nos últimos dez anos, de 2007 a 2016, localizadas nas bases de dados da Biblioteca Digital Brasileira de Teses e Dissertações e do Portal Periódicos da CAPES. Para essa busca, utilizamos os seguintes descritores: professor, docente, subjetividade, constituição subjetiva e sujeito.

Inicialmente destacamos que a realização de um estudo como esse traz vários desafios no seu processo de construção. Assim como Amaral 
(2011), também vivenciamos a situação de encontrar diversos trabalhos que contém os nossos descritores, porém não contemplam pesquisas sobre o tema que nos interessa. Na revisão de literatura realizada por Cardoso (2014) sobre a formação docente, em uma análise focada no professor e sua subjetividade, a autora constata que

[...] o tema é abrangente, e que as abordagens mais frequentes se inserem na formação inicial, formação continuada, prática pedagógica e processos de aprendizagem. Pouco se tem falado e pesquisado sobre a pessoa do professor, de como ele se constitui sujeito de um processo tão complexo, que é a educação. (p. 30)

A autora chegou a esse constatação a partir do levantamento que fez em publicações da ANPEd (Associação Nacional de Pós-graduação e Pesquisa em Educação), de 2007 a 2011. Na busca que realizamos também encontramos poucos trabalhos específicos sobre o processo de constituição subjetiva do professor. Apesar disso, esse procedimento nos possibilitou levantar reflexões frente à delimitação do nosso campo de pesquisa. Assim, apresentamos nesse capítulo os trabalhos que encontramos em relação às seguintes questões: como as pesquisas têm investigado o professor na perspectiva da sua constituição subjetiva? Quais abordagens sobre a subjetividade têm sido utilizadas na fundamentação teórica?

\subsection{Pesquisas sobre o professor na perspectiva da sua constituição subjetiva}

Considerando a seleção que realizamos, encontramos pesquisas que articulam o tema da subjetividade com questões que integram o trabalho docente, como por exemplo, educação especial (ROZEK, 2010), currículo (LEITE, 2015), metodologias (ANDRADE, 2008; KHOURI, 2015; OLIVEIRA, G. R., 2012), redes sociais (SALUM, 2012; SOUZA, E. P., 2013), condições de trabalho (LIMA, 2012), políticas públicas (DRUMOND, 2011), formação inicial e continuada (ALTARUGIO, 2007; ANDRADE, 2008; CARMO, 2014; 
DORNELLES, 2013; JOTZ, 2012; SANTOS, E., 2010; SOUZA, D. M. R., 2013; SOUZA, E. P., 2013; OLIVEIRA, J. G. M., 2011). Em relação às abordagens teóricas, encontramos a subjetividade fundamentada principalmente nas áreas da Filosofia, Psicologia e Sociologia.

O estudo desses trabalhos nos possibilita considerar que parte das pesquisas que relacionam a subjetividade a essas temáticas centralizam suas reflexões no assunto abordado e a constituição subjetiva do professor é analisada parcialmente. Entendemos que esse processo relaciona-se tanto com os objetivos das pesquisas, quanto com o referencial teórico adotado, que possibilita ou não um maior aprofundamento na análise da subjetividade.

Como exemplo, comentamos a pesquisa realizada por Leite (2015) que analisa porque as práticas pedagógicas dos professores de Educação Física tiveram poucas alterações apesar das propostas de mudanças das últimas décadas. Seu foco principal é analisar o assunto que propôs como tema para sua pesquisa, sendo a subjetividade abordada na perspectiva dos processos de subjetivação, analisando a cristalização de concepções dos professores sobre a sua prática. Justifica sua opção teórica em "Deleuze e Guatarri, pelo desenvolvimento de uma filosofia do acontecimento que toma a subjetividade como produção" (idem, 2015, p. 26). Entendemos que a constituição subjetiva dos docentes não é o foco principal do estudo proposto, pois centra-se em discussões de currículo e concepções de prática docente.

Assim também consideramos a pesquisa realizada por Andrade (2008), pois enfatiza concepções do ensino da língua estrangeira, relacionando com a subjetividade do professor. Analisa a constituição subjetiva docente no processo de formação de acadêmicos de licenciatura em Letras/Inglês, assumindo como referenciais os conceitos da psicanálise e do discurso, além dos estudos foucaultianos sobre a produção da subjetividade. Conclui que embora os professores em formação tendam a encarar a língua estrangeira e seus processos de ensino-aprendizagem de modo instrumental, o contato e a aprendizagem com uma língua estrangeira podem alterar sua subjetividade e constituir um modo singular de ensinar e aprender línguas. Ponderamos que a 
autora prioriza uma análise da subjetividade no processo de ensino e que a constituição subjetiva docente é abordada parcialmente.

Outra pesquisa que apresentamos como exemplo é a realizada por Salum (2012), que analisa a relação da constituição subjetiva de professores de inglês nas redes virtuais de relacionamento, em ambientes destinados a docentes dessa área. Fundamenta seu estudo nas teorias do discurso, da psicanálise freudiana e da desconstrução de Jacques Derrida e Michael Foucault, tratando de conceitos como: sujeito, identidade, discurso e modos de subjetivação. Compreende o sujeito como dotado de formas de subjetividade que são sempre múltiplas, heterogêneas, dispersas e fluidas, inserido em um processo social e historicamente determinado. Conclui sua pesquisa confirmando a hipótese que propôs inicialmente de que as "redes virtuais se constituem de instrumentos de controle, dispositivos de individuação, que remetem os professores participantes a assumirem determinadas posições de sujeito no ambiente virtual e no discurso didáticopedagógico" (idem, 2012, p. 166).

Consideramos que a pesquisa realiza por Jotz (2012) elabora uma análise que se aproxima mais da compreensão da constituição subjetiva do professor, apesar de também abordar a subjetividade relacionada a temas da profissão. Apoiada no referencial teórico da complexidade de Edgar Morin, a autora estuda a importância de reflexões sobre a prática pedagógica com grupos de professores na perspectiva da produção da subjetividade docente. Seu trabalho tem como objetivo oferecer uma visão de sujeito complexo, para que, a partir daí, se estude sob a ótica sistêmica complexa a produção de subjetividade através do pensar coletivo em grupos operativos. A autora conclui que na sua pesquisa "foram propostas e discutidas teorias explicativas sobre a produção de subjetividade em grupo operativo, a partir da reflexão acerca do fazer docente, bem como foi discutido um novo conceito de organizadores do pequeno grupo, juntamente com o entendimento dos princípios da complexidade" (idem, 2012, p. 133). Consideramos que a pesquisa contribui com abordagens em relação ao trabalho reflexivo com grupos de professores, enfatizando o valor das relações entre os pares no processo de constituição da subjetividade docente. 
Chamou-nos atenção que há uma incidência importante de pesquisas que investigam a subjetividade nos processos de formação docente. Dentre esse grupo, Altarugio (2007), por exemplo, analisa como a subjetividade do formador pode influenciar a subjetividade dos professores em formação. Amparada na psicanálise, a autora trabalha os conceitos de transferência, Outro, gozo e desejo, analisando as posições subjetivas dos sujeitos pesquisados em relação a esses elementos enquanto exercem a função de formadores de professores.

Outra pesquisa, também fundamentada na psicanálise, realiza um estudo da constituição subjetiva docente considerando a importância dos processos de formação inicial e continuada. J. G. M. Oliveira (2011) faz um estudo sobre a trajetória de vida de cinco professores, identificando as seguintes categorias de análise: um discurso impregnado pelo passado; o contexto pedagógico idealizado; a dimensão subjetiva da formação; as marcas positivas e negativas do percurso escolar; as identificações e transferências que constituíam a subjetividade; e o sentido da formação atravessada pela psicanálise. Consideramos que essas duas pesquisas, tanto a de Altarugio (2007), quanto a de J. G. M. Oliveira (2011), ao categorizarem a construção da análise centralizando as reflexões em conceitos definidos a priori, perdem a dimensão da singularidade constitutiva da subjetividade dos professores estudados.

A formação inicial é estudada em outras pesquisas sendo considerada como lócus de constituição da subjetividade do futuro professor. Dornelles (2013) estuda a formação do professor de Matemática, na perspectiva da complexidade de Edgar Morin, questionando-se como as dimensões subjetivas do ser humano, tais como a social, a emocional e a espiritual estão sendo desenvolvidas nos cursos de graduação. As análises sistematizadas apresentam crenças e posicionamentos dos futuros docentes frente à importância da mudança paradigmática que essa área do conhecimento precisa promover perante os desafios do contexto educacional.

O processo de tornar-se sujeito do seu processo de formação é analisado por E. Santos (2010) em pesquisa realizada junto a um grupo de 
docentes em cursos de Mestrado em Educação. Fundamentou sua análise na Sociologia da Ação, a qual se preocupa em dar visibilidade ao ator social em detrimento das estruturas sociais, amparado principalmente em Alain Touraine. Destacou os processos autoformativos como percurso de possibilidades na perspectiva da constituição dos professores como sujeitos da sua formação. Nesse sentido, valoriza as decisões e intervenções que fazem na própria trajetória, buscando superar as circunstâncias complicadas da sua história de vida.

Entendemos que as pesquisas que apresentamos até esse momento, as quais estudam temas da profissão docente articulando com a subjetividade do professor, contribuem para dar visibilidade ao enfoque subjetivo, uma abordagem importante e pouco presente em tais discussões. Entretanto, ponderamos que a análise de tais trabalhos apresenta-se insuficiente em relação à compreensão da constituição subjetiva do professor.

Assim, consideramos que outras pesquisas (ARRUDA, 2014; CORDEIRO, 2015; GALLERT, 2010; OLIVEIRA, L. S., 2013; REIS JÚNIOR, 2009; SANTOS, E. B., 2013; SANTOS, G. C. S., 2010; TELES, 2015), que assumem como referencial a Teoria da Subjetividade de González Rey (1997, 2004a, 2005a, 2005b, 2011b), alcançam uma discussão mais aprofundada sobre o processo da constituição subjetiva docente, pois o conceito de subjetividade é compreendido como

[...] um macroconceito que integra os complexos processos e formas de organização psíquica envolvidos na produção de sentidos subjetivos. A subjetividade se produz sobre sistemas simbólicos e emoções que expressam de forma diferenciada o encontro de histórias singulares de instâncias sociais e sujeitos individuais, com contextos sociais e culturais multidimensionais. (GONZÁLEZ REY, 2004a, p. 137)

Nessa perspectiva, para alcançar a compreensão sobre as produções subjetivas das pessoas, tais pesquisas assumem o desafio do processo construtivo-interpretativo na relação constante entre os momentos 
teórico e empírico, destacando-se o papel ativo e criativo do pesquisador. Com isso, apresentamos algumas pesquisas que, assim como em trabalhos anteriores, também analisaram a constituição subjetiva do professor nos seus percursos formativos, porém proporcionam reflexões com outras possibilidades interpretativas.

A pesquisa de L. S. Oliveira (2013), por exemplo, analisa os processos subjetivos de duas professoras nas ações formativas em que participavam. A construção interpretativa mostra sua constituição subjetiva na perspectiva de se configurarem subjetivamente enquanto sujeito apesar das circunstâncias nas quais a formação não atendia suas expectativas. Ao final a autora conclui:

A perspectiva da subjetividade de base histórico-cultural nos permitiu compreender, ao longo da pesquisa, processos e relações que se organizam na dinâmica de desenvolvimento do professor, a partir da análise de configurações subjetivas constitutivas e de novas unidades que podem emergir diante de experiências atuais. Essas configurações podem ser compreendidas, por meio da definição da categoria vivência, definida por Vigotski $(1983,2001)$. Nessa linha argumentativa, pode-se afirmar, a partir desta pesquisa, que, se a profissão de professor se converte em uma configuração subjetiva nuclear da pessoa, isso gera ações de envolvimento, compromisso e ação no desempenho da profissão. (idem, 2013, p. 154)

Sua pesquisa nos desafia para uma compreensão da subjetividade enquanto sistema singular na constituição de cada professor, cujo caráter gerador pode sinalizar possibilidades para o planejamento e a realização de ações formativas.

A pesquisa realizada por E. B. Santos (2013) também analisa professores em processos dinâmicos de ações formativas no cotidiano da vida escolar. O autor analisa como o professor produz o sentimento de pertencimento em relação ao processo conjunto de reorganização do trabalho docente, junto aos seus pares. Sua investigação aconteceu junto a dois grupos de professores que se reuniam periodicamente para rever a sua prática. $A$ construção interpretativa encaminhou-se no sentido de compreender que essa 
vivência possibilitou aos professores a formação continuada com processos colaborativos de reflexão, na perspectiva da constituição da autonomia, da autotransformação e do desenvolvimento pessoal e profissional. Finaliza argumentando que "no âmbito escolar, a autoctonia formativa se dá no processo de criação conjunta e compartilhada de necessidades sociais de desenvolvimento profissional em que o sujeito, o grupo e o contexto são transformados de forma contínua e interdependente" (idem, 2013, p. 242).

Encontramos em Teles (2015) outra pesquisa que analisa a constituição subjetiva nos processos formativos. Seu estudo envolveu acadêmicos e professores de um curso de Licenciatura em Educação do Campo, aprofundando principalmente os conceitos de sujeito, sujeito que aprende e subjetividade social. A autora destaca as múltiplas interconexões de um trabalho pedagógico implicado nas produções subjetivas dos processos de aprendizagem e desenvolvimento dos acadêmicos, na perspectiva de constituírem-se como sujeitos na sua relação com o conhecimento.

A pesquisa de Reis Júnior (2009) também segue nessa perspectiva ao analisar os sentidos subjetivos de um grupo de estudantes de Pedagogia em relação ao seu processo de verem-se como professoras. Sua construção interpretativa explica a articulação entre indicadores de núcleos de significação e sentidos subjetivos das acadêmicas em relação a como suas crenças integram a maneira como se vêem enquanto docentes. Destaca aspectos importantes para os cursos de formação na perspectiva do valor do afetivo, emocional e subjetivo articulado com os conhecimentos teóricos e práticos da profissão.

Além das pesquisas sobre a constituição da subjetividade docente em processos formativos, fundamentadas na Teoria da Subjetividade, encontramos investigações que analisam processos subjetivos do professor em relação a outros temas arrolados à profissão. Citamos como exemplo a pesquisa realizada por Cordeiro (2015) que faz uma análise da produção subjetiva de quatro professoras em relação ao processo da inclusão de alunos especiais no contexto escolar. Ao final da construção interpretativa sobre cada professora, a autora apresenta sínteses conclusivas parciais que mostram o 
quanto a constituição subjetiva é um processo complexo, singular e individual, configurado nas relações sociais da sua trajetória de vida, possibilitando que assumissem a condição de sujeito no exercício da docência no âmbito da educação especial.

Igualmente na área da educação especial, a pesquisa de G. C. S. Santos (2010) contribui para uma compreensão da complexidade dos processos subjetivos imbricados nos desafios da profissão. A autora analisa como a atuação junto a alunos com desenvolvimento atípico impacta subjetivamente a constituição subjetiva dos professores e como se configura o trabalho pedagógico na escola. Na sua pesquisa analisou três professoras iniciantes nessa área de atuação, mostrando processos subjetivos que geraram mudanças sistêmicas na sua subjetividade, na perspectiva de assumirem a condição de sujeito frente às circunstâncias do cotidiano. Sua construção interpretativa mostrou que tais processos se articulavam com a produção de sentidos subjetivos favoráveis a uma relação de responsabilização com seus alunos.

Citamos ainda outro trabalho nessa perspectiva, o qual analisa a constituição subjetiva de um grupo de docentes frente às adversidades do atual contexto da docência (GALLERT, 2010). A pesquisa apresenta processos de produção subjetiva dos professores na relação dinâmica e dialética das suas expectativas, realizações e frustrações para com a profissão que escolheram. Além disso, a autora elabora uma construção interpretativa sobre a constituição subjetiva de dois professores em relação a como subjetivavam o enfrentamento das adversidades da docência no cotidiano da sua atuação profissional.

Além dos trabalhos sobre o professor que buscam compreender a constituição subjetiva na perspectiva da Teoria da Subjetividade, encontramos também alguns que utilizam essa fundamentação articulando-a com outros referenciais (CARDOSO, 2014; COSTA, A. J. A., 2012; NOGUEIRA SOBRINHA, 2012; ROZEK, 2010). Citamos como exemplo a pesquisa realizada por ROZEK (2010) que estuda o processo da constituição subjetiva docente em relação à educação especial. Fundamenta a abordagem teórica em Fernando González Rey e na hermenêutica filosófica de Hans-Georg 
Gadamer. Suas análises mostram o percurso da trajetória de vida de duas docentes em relação ao valor que o trabalho com a educação especial tem na sua constituição. A maneira como constrói as suas análises destaca a opção pela abordagem filosófica e, apesar de fundamentar também na Teoria da Subjetividade, sua análise não alcança o mesmo aprofundamento interpretativo que as pesquisas de Cordeiro (2015) e G. C. S. Santos (2010) que estudaram o mesmo assunto. Isso porque sua sistematização centra-se na descrição de fatos da história de vida, apresentando poucas construções na perspectiva da constituição subjetiva.

Outra pesquisa que citamos como exemplo é a realizada por Nogueira Sobrinha (2012), que estuda o processo de formação inicial na perspectiva do processo de tornar-se professor. Sua pesquisa analisa uma turma de estudantes de um curso de Pedagogia da Terra na perspectiva de compreender a emocionalidade e os sentidos subjetivos em relação às vivências da formação. Além da Teoria da Subjetividade, a autora organiza a análise em três categorias do Materialismo Histórico Dialético: afetividade e cooperação, ideário pedagógico e trabalho, mostrando emoções, tensões e conflitos presentes no percurso da formação.

Dentre o conjunto de trabalhos que encontramos na busca realizada, consideramos que dois tiveram como foco principal a análise da constituição da subjetividade docente (CARDOSO, 2014; SOUZA, I. G. C., 2012). Cardoso (2014) buscou identificar os elementos constituintes da docência, a partir de relatos da trajetória de vida pessoal e profissional dos docentes, por considerar a estreita relação que há entre esses aspectos. Considera a subjetividade a partir de uma "opção humanística da educação de olhar o sujeito professor" (idem, p. 25), não definindo um autor na opção epistemológica na abordagem do conceito, mas situando sua compreensão em um conjunto de autores:

Nóvoa (1992; 1995; 1999), discute em seus estudos a relação estreita que existe entre a vida pessoal, profissional e a história de vida dos docentes, constituindo sua identidade; Gonzalez Rey $(1982 ; 1997 ; 2005)$ define o conceito de subjetividade docente na pesquisa qualitativa no processo de construção do conhecimento; Josso $(2004 ; 2010)$ fomenta a subjetividade docente através da experiência de vida e formação; Jesus 
(1996; 1998; 2002), Mosquera e Stobäus (2008) e Esteve $(1987 ; 1994 ; 1999)$ abordam a dimensão do mal-estar/bem-estar docente apontando causas, consequências e programas de formação; Morin (2005) propõe compreensão do paradigma da complexidade. (idem, p. 25)

A metodologia adotada foi quanti-qualitativa, com a aplicação de um questionário validado, que levantou indicadores de satisfação e insatisfação profissional, e entrevista semiestruturada com quatro docentes, utilizando a análise de conteúdo como procedimento para identificar os elementos constitutivos da subjetividade docente. A análise versou a partir das seguintes categorias de análise: identidade profissional abarcando realização, bem-estar docente e pertencimento a um grupo, e trabalho docente que tratou de questões sobre o saber ensinar, corpo de saberes e reconhecimento na profissão, as quais foram identificadas pela autora como contemplando as dimensões identitárias do eu profissional e do eu pessoal.

Nos resultados da parte quantitativa, a pesquisa identificou um grupo de docentes com elevado grau de motivação com a profissão e poucos indicadores de mal-estar docente. Em relação aos elementos constitutivos da subjetividade docente, Cardoso (2014) apresentou as seguintes análises, a partir dos relatos dos professores:

- sentir-se reconhecido pela instituição oportuniza o seu crescimento enquanto profissional da Educação, ajudando-o a construir o profissional que ele é e que deseja ser e que sentir-se pertencente a esse lugar cria identidade e alteridade a esse profissional;

- ser reconhecido na profissão pelo aluno e família é fator determinante para o professor sentir-se apto para o desempenho da sua função;

- sentir-se inserido, comprometido e respaldado por seu grupo de trabalho fortalece seu potencial pois se constrói no coletivo, descrevendo como uma necessidade social e por que não dizer, ontológica da docência;

- há uma indissociabilidade entre vida e profissão docente, de modo que essa identificação com a profissão, torna-se elemento de qualidade na sua prática;

- a opção pela docência como projeto profissional faz desse profissional um apaixonado pelo que faz, mesmo sendo um trabalho de muito desgaste relacional e muitas vezes, sem prestígio. (p. 90) 
Consideramos que o trabalho de Cardoso (2014) contribui para a compreensão da subjetividade docente, pois tem como foco o próprio professor e sua constituição no contexto das relações sociais do cotidiano profissional. Entretanto, entendemos que a metodologia adotada e a maneira como foi construído o referencial teórico, trazem limitações para uma compreensão complexa e aprofundada da constituição subjetiva dos professores que participaram da pesquisa.

Já a pesquisa de I. G. C. Souza (2012) avança ao realizar uma investigação sobre a constituição subjetiva do professor da Educação Infantil, amparada na Teoria da Subjetividade. Seu objetivo foi mapear os processos de subjetivação docente na escola de Educação Infantil, a partir de dois eixos: eu profissional, que analisa a trajetória até a docência na Educação Infantil, e eu na profissão, que investiga o exercício profissional docente. Utilizou como metodologia a pesquisa autobiográfica junto a um grupo de doze professores. Sua pesquisa contribui para uma compreensão da relação indissociável entre a constituição da subjetividade social e subjetividade individual na análise de cada professora, evidenciando principalmente as concepções que sustentam o seu fazer e viver a docência. Entretanto, considerando a metodologia adotada, entendemos que a construção interpretativa apresenta limitações na perspectiva da análise da constituição subjetiva das professoras em relação a uma compreensão coerente com o referencial teórico adotado.

Assim, frente ao exposto, e considerando o panorama das pesquisas apresentadas, seguimos para o próximo capítulo no qual detalhamos o percurso metodológico da nossa pesquisa sobre o professor que se configura enquanto sujeito da sua ação, assumindo a perspectiva de González Rey, para quem "la persona que se torna sujeto es la que desarolla alternativas propias en sus diferentes prácticas dentro de esos espacios, manteniendo su producción de sentidos subjetivos asociada a esos caminos propios" (2011a, p. 215). 
3 BASE EPISTEMOLÓGICA E METODOLÓGICA 


\section{BASE EPISTEMOLÓGICA E METODOLÓGICA}

A construção do percurso metodológico de uma pesquisa precisa ser coerente com os pressupostos epistemológicos do pesquisador em relação à visão que tem sobre o tema e o problema que pretende investigar. Sobre esse assunto, Vigotski (1983, p. 47) argumenta que o objeto e o método de investigação mantêm uma relação estreita, pois, "[...] a elaboração do problema e do método se desenvolvem conjuntamente, ainda que não de modo paralelo. A busca do método se converte em uma das tarefas de maior importância da pesquisa". Nessa perspectiva, considerando a complexidade do nosso tema, a compreensão da constituição subjetiva de professores que vivem a docência como sujeitos da sua ação, optamos pela escolha de um percurso metodológico cuja base epistemológica fosse coerente com tal proposta.

Partindo dessa premissa, apresentamos nesse capítulo as bases epistemológicas e o percurso metodológico que empreendemos na realização da pesquisa a fim de alcançar o objetivo geral de analisar a constituição subjetiva do professor que se configura enquanto sujeito da sua ação no espaço do seu trabalho educativo. Conforme apresentamos na introdução, esse foco foi desmembrado em três objetivos específicos:

- compreender as concepções que subjazem a prática pedagógica do professor e configuram a sua ação;

- explicar a produção subjetiva do professor em relação a demandas e desafios das diferentes situações cotidianas vividas na sala de aula e na escola;

- identificar expressões subjetivas que participam da configuração subjetiva do professor na sua ação docente. 


\subsection{Base epistemológica da pesquisa: a opção pela Epistemologia Qualitativa}

Considerando os objetivos, a problemática e o referencial teórico apresentados anteriormente, assumimos como pressuposto a importância da construção de um cenário de pesquisa que nos possibilitasse uma maior proximidade junto aos professores. A realização de uma pesquisa nessa perspectiva implicava indispensavelmente a construção de uma relação social de confiança, tendo em vista a compreensão de elementos constitutivos da subjetividade dos docentes envolvidos. Para tanto, era necessário mais do que a proposta de uma pesquisa qualitativa.

Alcançar a análise da constituição subjetiva de pessoas implica necessariamente o processo de assumirmos uma postura epistemológica na perspectiva de nos dispormos a uma imersão na vida cotidiana dos participantes. Exige-se do pesquisador uma postura para além da sua atuação somente como observador. A vivência dos procedimentos metodológicos implica no envolvimento simbólico-emocional entre o pesquisador e os participantes com o tema da pesquisa, ou seja, envolve processos de produção subjetiva (GONZÁLEZ REY, 2002, 2010, 2014a).

Assim, na perspectiva de uma metodologia que é elaborada processualmente no curso das articulações entre os momentos empíricos e teóricos, assumimos como pressuposto epistemológico e metodológico da nossa investigação a Epistemologia Qualitativa, elaborada por González Rey (1997, 2002, 2005a, 2010, 2014a). Esse pressuposto teórico-metodológico visa a superação da simples identificação da pesquisa qualitativa com a metodologia qualitativa, na perspectiva da compreensão do caráter subjetivo do próprio processo de construção do conhecimento que acontece no decorrer da investigação. Nesse sentido, o autor argumenta o seguinte: 
Partindo da Epistemologia Qualitativa, tento desenvolver uma reflexão aberta e sem âncoras apriorísticas em relação às exigências e às necessidades de produzir conhecimento em uma perspectiva qualitativa; tento buscar uma posição quanto às novas perguntas e respostas criadas ao implementar um processo diferente de construção do conhecimento, evitando assim transitar por novas opções utilizando princípios já estabelecidos por representações epistemológicas anteriores que não respondem aos novos desafios. Essa tentativa [...] [visa o] desenvolvimento de epistemologias particulares nos diferentes campos do conhecimento, fato que considero a única forma real de enfrentar os desafios epistemológicos que vão aparecendo nos campos metodológicos particulares de cada ciência. (GONZÁLEZ REY, 2010, p. 5).

Percebe-se a preocupação do autor em propor um processo de pesquisa que seja coerente com os desafios da sociedade atual. A realidade em constante mudança nos desafia, como pesquisadores, a superarmos a visão centrada nos instrumentos e na ideia de que estamos coletando dados para uma análise posterior. Ao invés disso, precisamos avançar na perspectiva de reconstruir permanentemente o processo da pesquisa, articulando dialeticamente a construção teórica com o momento empírico. Além disso, fazer pesquisa frente à complexidade do atual contexto nos desafia a assumir o papel de pesquisadores ativos, que produzem criativamente o processo da sua investigação como atores e autores do percurso teórico-empírico.

Tal processo está alicerçado nos três princípios da Epistemologia Qualitativa: o caráter construtivo-interpretativo do conhecimento; o caráter dialógico da investigação; e o valor do estudo de casos singulares como instância legítima de produção do conhecimento (GONZÁLEZ REY, 1997, 2002, 2005a, 2010, 2014a). Esses princípios, articulados entre si, sustentam 0 pesquisador no percurso dinâmico e processual que elabora e reelabora constantemente no curso da investigação.

Em relação ao caráter construtivo-interpretativo do conhecimento, destacamos o reconhecimento de que a realidade é um domínio infinito de campos interrelacionados de maneira complexa, e que a investigação nos possibilita a aproximação de parte dessa realidade, mas não da sua totalidade. Esse princípio também leva à compreensão do conhecimento como uma 
produção subjetiva e não como apropriação linear de dados sobre o contexto estudado.

A partir dessa perspectiva, González Rey (2005b, p. 6) elaborou o conceito de zonas de sentido, ou seja, os "espaços de inteligibilidade que se produzem na pesquisa científica e não esgotam a questão que significam, senão que pelo contrário, abrem a possibilidade de seguir aprofundando um campo de construção teórica". Sobre isso, na presente pesquisa delimitamos nosso campo na zona de sentido da configuração subjetiva de professores que se constituem como sujeitos da sua ação. Frente a isso, somos cientes de que a construção interpretativa alcançada e apresentada nessa tese traz contribuições sociais e científicas, mas não tem a pretensão de esgotar os estudos sobre o tema.

Assim, a identificação de zonas de sentido explicita o caráter de incompletude da pesquisa, pois ao concluir a investigação sobre um determinado problema, abrem-se novas possibilidades para a continuidade de outros estudos, que fazem com que o pesquisador construa teorias no decorrer das suas práticas investigativas. A construção de conhecimentos transversaliza os vários momentos da investigação desenvolvida. Não acontece em um momento pontual e único desse processo, mas é uma ação constante frente à multiplicidade de materiais empíricos sistematizados, se caracterizando pela atividade reflexiva, criativa e construtiva do pesquisador.

Outro princípio da Epistemologia Qualitativa é a compreensão da pesquisa como um processo de comunicação, um processo dialógico, pois a maioria dos problemas sociais e humanos se expressa na comunicação direta e indireta entre as pessoas. Nesse sentido, "a comunicação é uma via privilegiada para conhecer as configurações e os processos de sentido subjetivo que caracterizam os sujeitos individuais e que permitem conhecer 0 modo como as diversas condições objetivas da vida social afetam o homem" (GONZÁLEZ REY, 2005b, p. 13), fazendo com que o indivíduo se manifeste enquanto sujeito crítico e criativo. Esse princípio fundamenta também a escolha dos instrumentos da pesquisa, por meio dos quais a comunicação entre o 
pesquisador e os participantes se caracteriza como um espaço legítimo e permanente de produção de informações.

Considerando os itens anteriores evidencia-se o terceiro princípio da Epistemologia Qualitativa, a importância dos casos singulares como instância legítima de produção do conhecimento científico. González Rey (2010, 2011b, 2014a) defende que a compreensão do atual momento social implica em uma aproximação junto às pessoas que vivem efetivamente o problema de pesquisa que nos propomos a investigar. Nessa perspectiva, a construção teórica complexa sobre um tema, para que alcance a profundidade sobre como é vivido no cotidiano, não está relacionada com o valor científico a partir da quantidade de pessoas que participam da pesquisa. Ao invés disso, o valor se relaciona à qualidade das informações construídas na convivência com os participantes, tomando-se como referência o problema e os objetivos da pesquisa.

Assim, a partir das informações que os casos singulares expressam nas dinâmicas de comunicação, o pesquisador, envolvido em um processo de implicação intelectual e emocional, vivencia momentos de tensão, de ruptura, de continuidade e de contradições frente ao modelo teórico em desenvolvimento. Esses conflitos proporcionam o surgimento de novas zonas de sentido, que, consequentemente, provocam avanços na construção teóricometodológica da pesquisa e na compreensão da subjetividade enquanto sistema complexo.

Com isso, considerando a opção epistemológica que deu sustentação à construção teórico-empírica da pesquisa, apresentamos na sequência os movimentos de construção do percurso metodológico. Assumindo por referência a Epistemologia Qualitativa (GONZÁLEZ REY, 1997, 2002, 2005a, 2010, 2014a), as decisões e os encaminhamentos frente aos desafios nos orientaram na perspectiva de construirmos relações sociais de confiança e proximidade junto aos professores durante o processo investigativo, tendo em vista o estudo da sua constituição subjetiva. 


\subsection{Percurso metodológico: uma trajetória construída processualmente}

Considerando os pressupostos da Epistemologia Qualitativa (GONZÁLEZ REY, 1997, 2002, 2005a, 2010, 2014a), o percurso metodológico se configurou como um momento em que nos posicionamos de maneira ativa para que a pesquisa se concretizasse efetivamente. Arquitetar uma trajetória que nos possibilitasse construir informações qualitativamente relevantes frente ao problema e aos objetivos da nossa pesquisa, se apresentou como um desafio que se teceu processualmente. Vários questionamentos e reflexões foram levantados frente a decisões que as circunstâncias da convivência com os professores nos colocavam. Esses momentos evidenciaram a segurança na opção epistemológica da pesquisa, pois nos permitiu criar e recriar o percurso, tendo em vista o foco que buscávamos alcançar.

Assim, na sequência apresentamos a construção do percurso metodológico, tomando como referência a processualidade vivida no decorrer de cada momento. Organizamos a apresentação da seguinte maneira: a escolha da escola; a construção do cenário da pesquisa; o processo de decisão em relação aos professores que integrariam o estudo de casos; os instrumentos utilizados na construção das informações; e o processo da construção interpretativa das informações.

\subsubsection{A escolha da escola}

Realizamos o momento empírico da nossa pesquisa em uma escola pública de Ensino Médio, na cidade de Palmas - TO, no período de Março de 2015 a Janeiro de 2016. A escola se localizava em um bairro de periferia, atendendo alunos provenientes de famílias de classe socioeconômica baixa e média baixa. Era uma escola considerada de grande porte, em virtude de atender mais de dois mil alunos. 
Antes de chegarmos à decisão de que esse seria o cenário da nossa pesquisa, a escolha da escola tinha como referência inicial dois critérios: ser uma escola pública e de Ensino Médio. A adoção de tais critérios partia das seguintes justificativas:

- escolhemos o Ensino Médio em virtude da complexidade que caracteriza essa etapa da Educação Básica, principalmente em virtude de dois motivos. Os professores atuam por áreas do conhecimento específicas e, portanto, têm um tempo menor de contato semanal com os seus alunos, se comparado com os docentes das etapas anteriores. Além disso, os alunos encontram-se na faixa etária entre 15 e 17 anos, aproximadamente, período que compreende a fase da adolescência, um momento de indecisões em relação ao futuro, bem como de interesses pessoais que, muitas vezes, se distanciam das intencionalidades da escola. Consideramos que essas situações se apresentam como desafios para que o professor alcance os objetivos do seu trabalho, tornando o Ensino Médio uma realidade complexa para a sua atuação;

- escolhemos a escola pública, porque ela atende, na sua maioria, alunos provenientes das classes populares, situação que evidencia o valor social de uma ação pedagógica na perspectiva de um processo efetivo de aprendizagem e desenvolvimento. Além disso, outro aspecto é que, em geral, entende-se que a escola pública se configura como um local em que os desafios do professor são mais complexos do que na escola privada, principalmente em virtude da precariedade de recursos materiais e de estrutura física, das conflituosas relações de trabalho e da classe socioeconômica dos alunos.

Assim, considerando tais critérios, a escolha da escola especificamente na qual nos inserimos deu-se a partir da aproximação que tive com o grupo de professores e a Coordenação Pedagógica por ocasião de uma atividade profissional realizada na instituição alguns meses antes do período empírico. O grupo, naquele momento, mostrou-se receptivo à discussão dos desafios vividos na docência no atual contexto e tive acesso a algumas informações que considerei interessantes em relação à rotina escolar: vários professores realizavam projetos no decorrer do ano letivo; havia uma 
mobilização em relação à participação dos alunos em concursos e festivais, tanto na cidade quanto em outras localidades; a organização do espaço-tempo das aulas acontecia com a proposta de salas ambiente, ao invés de salas de aula para cada turma de alunos; a escola atendia uma quantidade grande de alunos.

$\mathrm{Na}$ ocasião consideramos que essas informações poderiam sinalizar a subjetividade social de um grupo escolar que vivia o seu cotidiano de uma maneira ativa e atuante em relação a situações que extrapolavam a rotina de aulas restritas ao contexto da sala de aula. Nessa perspectiva, levantamos a hipótese de que a adesão a tais situações implicava provavelmente a atuação de professores que viviam como sujeitos da sua ação, o que sinalizava que talvez essa escola fosse um local propício em relação aos objetivos de estudo.

Entretanto, o processo da construção interpretativa nos possibilitou compreender que outras escolas também seriam contextos escolares em que encontraríamos professores para o estudo de casos na perspectiva do nosso tema. Os grupos escolares são formados por professores únicos e singulares, dentre os quais, na complexidade da sua constituição subjetiva, também encontraríamos outros que se configuram como sujeitos da sua ação.

Assim, após contato formal junto à Secretaria Estadual de Educação do Tocantins, por meio de ofício encaminhado em Janeiro de 2015 (Apêndice I), recebemos autorização para a realização da pesquisa no final de Fevereiro. Entretanto, somente após um mês começamos os contatos com a escola, pois a Secretaria solicitou que aguardássemos a publicação dos nomes dos novos diretores no Diário Oficial, situação que aconteceu no final de Março. Assim que tal fato aconteceu, contatamos com a Direção para nos inserirmos no cotidiano da escola, havendo receptividade e acolhida já nas conversas iniciais. 


\subsubsection{A construção do cenário social da pesquisa}

A entrada no campo de pesquisa se caracteriza por um momento tenso para o pesquisador, pois não sabe como serão as relações sociais estabelecidas com as pessoas com quem vai conviver. Na perspectiva da Epistemologia Qualitativa (GONZÁLEZ REY, 1997, 2002, 2005a, 2010, 2014a), esse momento é identificado como a construção do cenário social da pesquisa, o qual "tem por objetivo apresentar a pesquisa para os possíveis sujeitos que dela vão participar, e sua função principal é envolver o sentido subjetivo dos que participam da pesquisa" (GONZÁLEZ REY, 2010, p. 83).

Esse momento demanda paciência do pesquisador e habilidade nas relações interpessoais, pois, para além de somente informar os participantes sobre a pesquisa, implica também em um processo de envolvimento simbólico-emocional dos mesmos com o tema a ser investigado. Nessa perspectiva,

O cenário social da pesquisa [...] não é um lugar estático, mas configurado como um espaço de relações. Diferente do local da pesquisa, o cenário social da pesquisa é uma construção relacional do pesquisador, um espaço de relações entre os sujeitos que integram o espaço a ser pesquisado. A principal função da constituição do cenário social com os participantes da pesquisa é o estabelecimento de uma relação dialógica e comunicacional com os mesmos. O seu processo de constituição é o momento de desenvolver essa relação, quando os participantes poderão ver, no pesquisador, uma pessoa de confiança e, principalmente, sentirem-se motivados a participar da pesquisa. (ROSSATO; MARTINS; MITJÁNS MARTÍNEZ, 2014, p. 42, grifo dos autores)

Esse processo demanda o investimento de tempo no período empírico da investigação, não é algo dado ou que acontece repentinamente. Ao invés disso, a construção do cenário social da pesquisa acontece gradativamente na processualidade da convivência cotidiana com as pessoas. Enquanto pesquisadores, inicialmente assumimos a posição de estranhos no grupo e, em alguns momentos, a sensação é de que estamos invadindo a privacidade da sua vida social. Entretanto, aos poucos, esse clima vai se 
dissipando e a nossa presença vai tornando-nos um integrante do grupo, chegando ao estabelecimento de vínculos com os participantes e criando um espaço de relações sociais e de comunicação.

Em relação a nossa pesquisa, entendemos que a construção do cenário social aconteceu em dois momentos, interrelacionados entre si: a relação de confiança com o grupo e a escolha dos professores que integrariam o estudo de caso. Nesse tópico abordaremos o primeiro momento e o segundo será apresentado na sequência, no próximo subtítulo. Entendemos que foram dois momentos em virtude de que, quando começamos o processo de acompanhamento dos professores do estudo de casos, apesar de já sentirmos que integrávamos o grupo, foi necessário o estabelecimento de uma relação social de proximidade e confiança mais intensa. Isso porque buscávamos um envolvimento simbólico-emocional maior desses sujeitos com a pesquisa, tendo em vista compreender a constituição da sua subjetividade.

Assim, a partir do contato receptivo da Diretora em relação à pesquisa, a entrada no campo deu-se no final de Março de 2015 e aconteceu gradativamente com a apresentação aos professores e equipe da Coordenação Pedagógica e Orientação Educacional. Considerando que a escola funcionava nos três turnos, conforme explicaremos no próximo capítulo na construção interpretativa das informações, optamos pela realização da pesquisa junto aos docentes do turno matutino.

A receptividade inicial do grupo foi tranquila e alguns se lembraram do momento que tivemos no ano anterior. Em um dos encontros iniciais explicamos os objetivos e procedimentos da pesquisa, entregamos aos professores o Termo de Consentimento Livre e Esclarecido (Apêndice II) e solicitamos sua assinatura, caso concordassem. Houve unanimidade na assinatura do referido documento.

A inserção na rotina da escola aconteceu com observações na sala dos professores e acompanhamento das atividades cotidianas. Esse processo aconteceu com uma periodicidade semanal de um a três dias, com uma permanência média de aproximadamente três horas na escola. As observações eram registradas em um bloco de notas e posteriormente 
organizadas em relatórios que nos ajudavam a construir o percurso das decisões e encaminhamentos do período empírico da pesquisa. Considerando a quantidade de situações e acontecimentos que vivíamos, optamos pela organização pessoal de uma tabela para a sistematização do fluxo do percurso metodológico.

Além das observações, outra estratégia que usamos nas primeiras semanas de contato com a escola foi a realização de entrevistas com os três Coordenadores Pedagógicos e a Orientadora Educacional (Apêndice III). A partir de um breve roteiro preparado para essa conversa, buscamos conhecer suas percepções sobre o grupo de professores, bem como sobre cada docente. A maneira como aconteceram esses momentos evidenciaram a receptividade da equipe gestora em relação à pesquisa, proporcionando o acesso a informações importantes sobre o funcionamento do grupo de professores frente à dinâmica e aos desafios cotidianos da escola. Tais informações sinalizavam possibilidades para a compreensão da subjetividade social do grupo de professores que participava da pesquisa.

No início das observações era aparente que alguns se sentiam desconfortáveis com a minha presença na sala dos professores. Parte do grupo de mostrava curiosa e, com frequência, fazia perguntas sobre 0 andamento da pesquisa, o tema e os procedimentos para ingressar em cursos de Mestrado e Doutorado. Entretanto outros seguiram reticentes e se mantiveram distantes durante vários meses. Alguns professores não permitiram o acesso e permaneceram distantes durante todo o período da pesquisa. Apesar disso, percebemos que, após algumas semanas, o cenário social foi se configurando na perspectiva da construção de interações favorecedoras na perspectiva de alcançarmos os objetivos propostos.

\subsubsection{A decisão em relação aos professores que integrariam o estudo de casos}

Consideramos que um dos momentos mais complexos e desafiadores do percurso metodológico foi a decisão em relação a quais seriam 
os professores com os quais teríamos uma maior aproximação na perspectiva da análise da constituição subjetiva. Tínhamos diversas dúvidas e incertezas desde o início da construção do cenário social da pesquisa e, a cada novo momento vivido, nos perguntávamos se esse ou aquele professor seria ou não um possível participante para a etapa do estudo de casos.

Entendemos que os desafios dessa decisão e do acompanhamento desses professores nos possibilitaram viver com intensidade os argumentos defendidos por González Rey (2005a, 2010, 2011b, 2014a), Mitjáns Martínez (2014) e Madeira Coelho (2014) em relação à postura ativa e criativa do pesquisador. A construção de relações sociais na perspectiva de um envolvimento emocional desses professores com a pesquisa foi um processo contínuo que aconteceu não somente em virtude das estratégias metodológicas. Compreendemos que as produções subjetivas implicadas, tanto dos professores, quanto minhas enquanto pesquisadora, possibilitaram que alcançássemos a construção teórica que sistematizamos em relação à tese.

Nessa perspectiva, esse processo exigiu atenção aos detalhes do cotidiano e reflexão constante em relação a circunstâncias que sinalizavam possibilidades para a escolha dos professores. Considerando que não conhecíamos o grupo, decidimos inicialmente pela realização da entrevista com os Coordenadores Pedagógicos e com a Orientadora Educacional, conforme explicamos no tópico anterior. Nessa conversa levantamos algumas suposições em relação a alguns professores, as quais fomos compreendendo de maneira mais apurada nas observações do cotidiano. Considerando que partíamos do olhar de integrantes da equipe gestora, os quais realizavam funções diferentes na rotina da escola, percebemos que havia convergências e divergências nas suas colocações em relação a alguns professores que abordavam.

Assim, o acompanhamento dos professores em atividades diversas do cotidiano escolar, conforme detalharemos no próximo tópico, e a relação de confiança que se estabeleceu com alguns de forma mais efetiva, nos possibilitou decidir por algumas possibilidades em relação a quem participaria do estudo de casos. Decidimos inicialmente pela aproximação junto 
a um grupo de seis professores, os quais, cada um a sua maneira, participavam e se engajavam com atividades e/ou situações do cotidiano, demonstrando comprometimento com os alunos, com a escola e com a profissão, bem como manifestavam abertura e vontade de se inserir na pesquisa. Assim, essas suposições, advindas das informações da pesquisa, nos possibilitaram tomar decisões. Chegamos a essas constatações em meados do mês de Agosto, a partir do acompanhamento que realizamos desde Abril e que foi interrompido em Junho e Julho em função da greve.

Em relação ao estudo de casos, González Rey (2010) destaca a importância da singularidade no potencial teórico que assume frente ao processo de inteligibilidade construído pelo pesquisador:

O valor do singular está estreitamente relacionado a uma nova compreensão acerca do teórico, no sentido de que a legitimação da informação proveniente do caso singular se dá através do modelo teórico que o pesquisador vai desenvolvendo no curso da pesquisa. A informação ou as ideias que aparecem através do caso singular tomam legitimidade pelo que representam para o modelo em construção, que será responsável pelo conhecimento construído na pesquisa. (p. 11)

Desse modo, a escolha dos professores participantes do estudo de casos se constituiu em um processo complexo e cuidadoso, tendo em vista a construção teórica que buscávamos realizar em relação ao assunto da nossa pesquisa. Assim, de Agosto a Dezembro seguimos com o acompanhamento da rotina da escola e realizamos alguns procedimentos metodológicos especificamente com os seis professores selecionados a partir do processo descrito acima. Os procedimentos começavam com uma entrevista (Apêndice V), a partir de um roteiro com alguns eixos norteadores para a conversa. Ao final desse momento solicitávamos autorização para acompanhar o professor no cotidiano das suas aulas.

O processo começou inicialmente com uma professora que manifestava interesse constante pela pesquisa e conversava com frequência 
sobre situações das suas aulas. A professora prontamente se colocou à disposição para as observações, sendo que a acompanhamos nas suas aulas construindo uma relação de proximidade e engajamento com a pesquisa, que se mostrava promissora tendo em vista os nossos objetivos. A professora participou também de outros momentos da pesquisa: o completamento de frases, a elaboração do Diário "O cotidiano de um professor" e da Linha do Tempo, instrumentos que serão explicados no próximo tópico.

Essa aproximação aconteceu também com mais dois professores. Ambos tiveram um envolvimento intenso com a pesquisa. Com um deles não conseguimos finalizar a dinâmica conversacional a partir dos registros da Linha do Tempo, em virtude de situações que o envolveram e inviabilizaram sua disponibilidade para esse momento. Apesar de entendermos que um instrumento de pesquisa não é decisivo em relação à pesquisa como um todo, decidimos pela análise do caso do outro professor, a quem denominamos pelo nome fictício de Nícolas, a fim de preservar a sua identificação.

A escolha do nome que atribuímos a esse professor não foi aleatória, mas assume um significado e um sentido relacionado com situações da sua trajetória de vida. Escolhemos esse nome como alusão a Nícolas Flamel, considerado um dos mais importantes alquimistas da história, que viveu de 1330 a 1418, a quem é atribuída a criação da fórmula da Pedra Filosofal, o elixir da longa vida ${ }^{3}$. Conforme discorreremos nos próximos capítulos, viver era algo muito precioso e intenso para ele, tendo registrado suas reflexões sobre a vida em um livro que escreveu e publicou, cujo nome relacionava-se com a alquimia.

Com esse professor estabeleceu-se uma relação de confiança, comunicação e proximidade favorecedora de dinâmicas conversacionais que geraram informações importantes frente aos objetivos que buscávamos alcançar. Houve um envolvimento emocional intenso do professor com a pesquisa, compartilhando relatos e reflexões que possibilitaram a construção

3 "Há a lenda de que Nicolas Flamel ao fazer o caminho de Santiago da Compostela teria encontrado um sábio judeu que decifrou os símbolos contidos em um antigo livro, o qual o célebre alquimista há muito adquirira, mas não conseguia decifrar. Esse encontro permitiu a Flamel conhecer a fórmula para a criação da pedra filosofal." (COSTA, A., 2012, p. 31) 
de hipóteses interpretativas sobre elementos da sua constituição subjetiva, conforme apresentamos no próximo capítulo.

Além desses professores, tivemos ainda a participação de mais três docentes, com os quais realizamos uma entrevista, observamos um dia de aula e eles participaram do instrumento do completamento de frases. Dentre esses três, um professor manifestou-se receoso em relação às observações das aulas. Respeitamos o seu posicionamento e não o acompanhamos no seu cotidiano com os alunos. Esses professores não participaram dos momentos do Diário "O cotidiano de um professor" e da Linha do Tempo. A decisão pela sua participação dessa maneira, diferente dos demais, deu-se em virtude de que, em dado momento do período empírico, sentíamos a necessidade de ampliar o nosso espectro de visão em relação ao encaminhamento que fazíamos para decidir pelos professores que havíamos selecionado para 0 estudo de casos.

Assim, considerando as explicações apresentadas, dentre os seis professores que participaram dos momentos individuais de conversas e registros, selecionamos o Professor Nícolas para a análise do estudo de casos. A escolha, desse professor, que se configurou como um momento desafiador do percurso metodológico, deu-se em virtude do potencial de construções interpretativas que as informações apresentadas por ele, a sua participação e o seu envolvimento geraram para a nossa pesquisa.

Em relação à quantidade de casos de uma pesquisa alicerçada na Epistemologia Qualitativa, González Rey (2002) argumenta que o conhecimento científico

[...] não se legitima pela quantidade de sujeitos a serem estudados, mas pela qualidade de sua expressão. $O$ número de sujeitos a serem estudados responde a um critério qualitativo, definido essencialmente pelas necessidades do processo de conhecimento que seguem no curso da pesquisa. [...] A informação expressa por um sujeito concreto pode converter-se em um aspecto significativo para a produção de conhecimento, sem que tenha de repetir-se necessariamente em outros sujeitos. (p. 35) 
Assim, a opção pela elaboração da construção interpretativa a partir do estudo de caso de um professor, deu-se em virtude do potencial que o conjunto das informações proporcionou frente ao problema e aos objetivos que nos propomos investigar. A participação dos demais professores, tanto os cinco que participaram dos momentos que descrevemos, quanto os que observamos na rotina da escola, também contribuiu para a construção interpretativa. Isso porque, conforme sistematizamos no próximo capítulo, a constituição da subjetividade não se processa de maneira isolada, mas implica a complexa tecitura das relações sociais nas quais as pessoas estão envolvidas e implicadas subjetivamente.

\subsubsection{Os instrumentos utilizados no processo de construção das informações}

Conforme a Epistemologia Qualitativa (GONZÁLEZ REY, 1997, 2002, 2005a, 2010, 2014a), os instrumentos que usamos para realizar a pesquisa não são utilizados para levantar ou coletar dados. Ao invés disso, são compreendidos como momentos que possibilitam a construção de informações sobre o tema que nos propomos investigar. São indutores para momentos dialógicos ou de registros, seja com a escrita, o desenho, dentre outras maneiras, que possibilitam a abertura de canais para a expressão dos participantes da pesquisa.

Frente a isso, o principal instrumento de pesquisa que utilizamos foram as dinâmicas conversacionais, que aconteceram de duas maneiras. Em alguns momentos foram planejadas com um roteiro de assuntos e/ou perguntas disparadoras do diálogo, sendo gravadas, mediante a autorização dos participantes, e posteriormente transcritas. Noutros momentos fluíram na informalidade das relações interpessoais no processo de acompanhamento do cotidiano escolar, as quais foram registradas no diário que nos acompanhava no decorrer das observações. 
Em relação às dinâmicas conversacionais planejadas com roteiros, foram realizados os seguintes momentos:

- diálogos com três Coordenadores Pedagógicos, que aconteceram em Abril, e com a Orientadora Educacional, em Agosto, tendo em vista levantar informações sobre o cotidiano da escola e o funcionamento do grupo de professores (Apêndice III);

- discussão em grupo com três professores que não aderiram à greve. Esse momento aconteceu em Junho, durante o período da paralisação, a fim de conhecermos a sua compreensão sobre esse momento e o seu posicionamento e postura em relação aos demais colegas (Apêndice IV);

- diálogos com seis professores, no decorrer de Agosto a Novembro, para conhecermos a sua trajetória profissional e como viviam a docência (Apêndice V);

- diálogos sobre os registros no Diário "O cotidiano de um professor". Essa conversa aconteceu em dois momentos com dois professores e uma vez com um professor, no decorrer de Novembro e Dezembro (Apêndice VIII);

- diálogo sobre os registros na Linha do Tempo, que aconteceu com dois professores, em Janeiro (Apêndice X).

Além desses diálogos, aconteceram diversos momentos de conversas informais no decorrer das observações do cotidiano da escola, que aconteceram do final de Março de 2015 a Janeiro de 2016, principalmente na sala dos professores. Além da observação da vida que acontecia nesse local de encontro cotidiano do grupo, acompanhamos outros momentos, como por exemplo, Conselhos de Classe, reuniões, projetos, aula-campo, festas, eventos com a participação da comunidade escolar, dentre outros. Foram ainda acompanhadas aulas dos professores que participaram de instrumentos mais específicos, conforme descrevemos acima. O conjunto das observações aconteceu em um total de setenta dias em que estive presente acompanhando a rotina da escola. 
Além do acompanhamento do movimento intenso da vida da escola, utilizamos também os seguintes instrumentos escritos:

- completamento de frases (Apêndice $\mathrm{VI}$ ): o instrumento foi elaborado com 75 indutores, ou seja, frases incompletas que os professores preencheram conforme o que pensavam e sentiam em relação a sua profissão naquele momento. Foi realizado com um grupo de vinte professores, em Novembro, no início de uma reunião do Conselho de Classe;

- Diário "O cotidiano de um professor" (Apêndice VII): o instrumento foi preparado em um caderno pequeno entregue a cada um dos três professores que participaram desse momento da pesquisa, conforme apresentamos no tópico anterior. Solicitamos que eles fizessem quantos registros quisessem sobre o seu cotidiano profissional, colocando situações, emoções, relatos, etc. O registro poderia ser feito com descrições, relatos, poesias, imagens, desenhos, colagens, etc. A entrega desse material a cada professor aconteceu após algumas observações de aulas, momento em que acordamos com cada um que, depois de algumas semanas, agendaríamos um momento de conversa sobre os seus registros. A professora esteve com o Diário durante treze semanas, fez oito registros e tivemos dois momentos de conversa; o Professor Nícolas fez quatorze registros no decorrer de nove semanas e tivemos dois encontros de conversa sobre o instrumento; e o outro professor fez nove registros durante três semanas e realizamos um momento de conversa;

- Linha do Tempo (Apêndice IX): o instrumento foi preparado em um cartaz no qual desenhamos uma linha do tempo com a idade do professor, sendo realizado com três professores, conforme colocamos anteriormente. Solicitamos que fizessem tanto registros quantos quisessem em relação a sua trajetória de vida, registrando os acontecimentos que consideravam importantes. O registro poderia ser feito de forma textual, com desenhos, fotos ou imagens. A entrega do material aconteceu em Dezembro para cada professor, ficando combinado que no retorno à escola, em Janeiro, agendaríamos um momento para dialogarmos sobre os registros que haviam feito. O material foi entregue para três professores, porém conseguimos 
realizar o momento da conversa somente com a professora e o Professor Nícolas, conforme explicamos no tópico anterior.

No decorrer do período empírico realizamos ainda a pesquisa documental em materiais diversos, como por exemplo: Projeto PolíticoPedagógico da escola; fichas de registro dos Conselhos de Classe; publicações oficiais e recados divulgados nos murais da escola; reportagens sobre a escola publicadas na mídia (televisão, jornais eletrônicos e impressos, site da Secretaria Estadual de Educação); postagens no Facebook do Grêmio Estudantil e de alguns professores; dentre outros materiais. A consulta a esses materiais nos proporcionou alguns esclarecimentos e uma melhor compreensão sobre situações relacionadas à dinâmica da escola.

Esse conjunto de instrumentos gerou uma quantidade generosa de informações sobre a escola, o grupo de professores e a constituição subjetiva de alguns docentes, sendo desafiador também o processo ativo e criativo da construção interpretativa frente a tantos registros sistematizados no decorrer do percurso metodológico.

\subsubsection{O processo da construção interpretativa das informações da pesquisa}

A construção interpretativa das informações se constitui em um momento complexo para nós pesquisadores, pois exige que assumamos uma postura ativa e criativa, como atores e autores do processo de construção da sistematização da investigação. Conforme a Epistemologia Qualitativa (GONZÁLEZ REY, 1997, 2002, 2005a, 2010, 2014a), a construção interpretativa das informações não é um momento que acontece somente após a etapa empírica da pesquisa. Sobre isso, Madeira Coelho (2014) explica que 
[...] a empreitada empírica em vez de procurar um fim em si mesma, articula-se às questões teóricas e epistemológicas. $\mathrm{E}$ então, de forma coerente, o trabalho de construção da informação se organiza em processos de idas e vindas que relacionam os planos epistemológico, teórico e empírico. Ao mesmo tempo em que permite o delineamento do estudo empírico, o marco epistemológico e teórico é transformado pelo próprio estudo que o gerou, com um retorno de problematizações que permitam o avanço continuado da reflexão teórica. (p. 95)

Assim, no decorrer do período em que estamos no contexto da investigação, as reflexões, os questionamentos e as análises já começam a ser sistematizados. Esse processo inicia com a construção de indicadores, os quais sinalizam possibilidades de hipóteses interpretativas frente ao problema e objetivos propostos, "como um recurso de produção de inteligibilidade" (GONZÁLEZ REY, 2014a, p. 28).

Esse procedimento acontece processualmente, pois os indicadores não são categorias definidas a priori, antes da entrada no contexto da investigação. Ao invés disso, tendo como foco o problema e os objetivos propostos, o convívio dialógico com os participantes da pesquisa possibilita o acesso a informações que nos levam a processos reflexivos e interpretativos na perspectiva de destacar pontos que merecem aprofundamento. Assim, o indicador "é uma ideia que se torna orientadora para abrir uma possível hipótese no curso da pesquisa; pois o próprio indicador tem caráter hipotético, por isso, é sempre uma ideia do pesquisador, nunca um significado inerente ao fato, que pode explicar o fato sobre o qual se originou" (idem, p. 28).

Com isso, convém destacar que na processualidade do processo construtivo-interpretativo os indicadores são hipóteses explicativas provisórias, pois podem mudar no curso da pesquisa. Isso significa que os indicadores elaborados no início do período empírico podem ser modificados e inclusive abandonados no decorrer do processo, pois outros podem revelar-se como sendo de maior importância na medida em que a pesquisa avança e outras reflexões são construídas. 
Outra questão importante na construção dos indicadores refere-se ao fato de que a sua elaboração não está relacionada com uma análise quantitativa em relação a uma incidência maior de algum assunto abordado pelos participantes da pesquisa. Esse pode também ser um fator a ser considerado. Entretanto, há indicadores qualitativamente relevantes que podem aparecer pouco nas informações apresentadas, mas que assumem um valor de importância significativa no processo construtivo-interpretativo. González Rey e Mitjáns Martínez (2016) explicam que

Los indicadores son herramientas del pensamiento para garantizar la continuidad procesal de los caminos hipotéticos abiertos por la investigación. El curso de una investigación cualitativa constructivo-interpretativa es un proceso hipotético que puede ser negado por la emergência de nuevos indicadores que refuten el camino dominante de la construcción teórica hasta ese momento. El investigador es responsable por sus decisiones en el curso de la investigación, ningún instrumento lo exime de su responsabilidad. (p. 10)

Tal processo exige que estejamos em postura de vigilância reflexiva constante, construindo e reconstruindo tanto o percurso metodológico, quanto as possibilidades interpretativas que as situações vividas proporcionam. Nessa perspectiva, convém destacar que não existe uma padronização de procedimentos a ser adotada no processo construtivo-interpretativo, pois cada pesquisador tem um percurso próprio. A singularidade desse processo acontece dessa maneira em virtude de estar articulada com os processos subjetivos do próprio pesquisador em relação à investigação que propôs e assumiu empreender na sua trajetória.

Finalizando as explicações, consideramos importante destacar uma situação que vivemos no processo construtivo-interpretativo da pesquisa. O percurso metodológico que construímos possibilitou termos acesso a informações quantitativa e qualitativamente importantes em relação ao problema e aos objetivos que propomos. Após o período empírico, quando trabalhávamos na construção interpretativa de forma mais intensa, nos deparamos com a situação de que as informações possibilitavam certo alcance 
em relação a alguns indicadores, porém parecia que ainda poderia haver mais alguma complementação. Buscávamos um aprofundamento interpretativo para - qual parecia ser necessário confirmar algumas informações junto ao professor com o qual realizamos o estudo de caso.

Assim, organizamos um novo momento dialógico com o Professor Nícolas, que aconteceu em Maio, após o período empírico, no qual compartilhamos com ele a construção interpretativa dos indicadores que estávamos elaborando (Apêndice XI). Esse foi um movimento que consideramos importante no percurso da nossa investigação, pois o professor teve a oportunidade de participar ativamente do processo construtivointerpretativo. Em dado momento da conversa ele apresentou uma fala que nos ajudou a compreender que fomos assertivas com a realização desse procedimento:

"Eu acho que sim, que você chegou a conclusões acertadas. Eu acho que você teve uma boa visão! Acredito que sim. Eu acho que você teve uma visão até melhor do que eu! Geralmente quem está de fora tem uma visão da gente melhor do que a gente mesmo. Cecília Meireles é quem dizia: 'Somos geralmente um pouco menos do que dizemos, raramente um pouco mais'. Então eu acho que você me viu melhor do que eu mesmo me vejo!"4

A dinâmica conversacional que tivemos com o Professor Nícolas nesse momento socializando a construção de alguns indicadores foi um momento potencializador de informações qualitativamente importantes para a construção interpretativa que apresentamos no próximo capítulo. Algumas informações foram apresentadas por ele apenas nesse momento e constituíram-se em pontos essenciais para a compreensão da sua constituição subjetiva.

\footnotetext{
${ }^{4}$ Dinâmica conversacional durante o processo construtivo-interpretativo das informações da pesquisa - 16.05.16.
} 
Entendemos que a vivência desse processo, tão importante para a nossa investigação, só foi possível em virtude da base epistemológica que assumimos, pois permitiu o movimento dialético e dinâmico da construção dos nossos próprios caminhos, tendo em vista alcançar os propósitos aos quais nos propomos. Se estivéssemos alicerçadas em outra perspectiva teórica e metodológica, provavelmente a construção interpretativa não alcançaria o aprofundamento que a Epistemologia Qualitativa (GONZÁLEZ REY, 1997, 2002, 2005a, 2010, 2014a) nos possibilitou e desafiou frente ao processo de nos assumirmos enquanto sujeitos na elaboração da nossa pesquisa. Assim, seguimos para o próximo capítulo, no qual sistematizamos a construção interpretativa das informações geradas no percurso teórico-metodológico da nossa pesquisa. 
4 CONSTRUÇÃO INTERPRETATIVA A PARTIR DAS INFORMAÇÕES GERADAS NA PESQUISA 


\section{CONSTRUÇÃO INTERPRETATIVA A PARTIR DAS INFORMAÇÕES GERADAS NA PESQUISA}

Nesse capítulo apresentamos a construção interpretativa das informações dividida em duas partes. Na primeira parte sistematizamos informações sobre o contexto escolar no qual realizamos o período empírico da nossa pesquisa, sinalizando alguns elementos que constituíam a subjetividade social dessa realidade. Na sequência discorremos sobre o estudo de caso realizado com o Professor Nícolas, organizando essa parte em quatro abordagens interrelacionadas entre si: apresentação do professor e a escolha da profissão; a importância da profissão e do seu local de trabalho; a maneira como realizava o seu trabalho e como aconteciam as relações sociais que estabelecia com seus alunos e colegas de trabalho no contexto da escola; a maneira como se posicionava frente às demandas e desafios do cotidiano. No decorrer dessas abordagens construímos os argumentos e as hipóteses interpretativas sobre os elementos que integravam a constituição subjetiva de Nícolas, possibilitando-Ihe viver a docência enquanto sujeito da sua ação.

\subsection{0 contexto escolar}

O processo de construção das informações da pesquisa aconteceu junto aos professores e equipe gestora de uma escola pública de Ensino Médio, em Palmas - TO. A escola funcionava desde 1991 e localizavase em um bairro periférico da cidade, situada em uma região comercial e residencial. Os alunos eram provenientes de famílias de classe socioeconômica baixa e média baixa, e muitos trabalhavam para ajudar no 
sustento familiar. Parte dos alunos era da zona rural e deslocava-se diariamente com o transporte público escolar.

A escola era considerada uma instituição de grande porte, pois atendia 2506 alunos no ano em que realizamos a pesquisa. Para atender a essa demanda a escola contava com uma equipe formada pelos seguintes profissionais: 71 professores, uma diretora, cinco coordenadores pedagógicos, três orientadoras educacionais, dois professores cuidadores que acompanhavam alunos especiais, um coordenador financeiro, uma bibliotecária, três secretários, três vigias e oito funcionários de serviços gerais.

O funcionamento cotidiano da escola era intenso, com uma organização de aulas que aconteciam nos três turnos. O turno matutino era o mais procurado pela comunidade escolar para matrículas, concentrando o maior número de alunos, professores e funcionários. Considerando a abrangência da organização e do funcionamento da escola, optamos pela realização da pesquisa no turno matutino, em virtude de considerarmos que esse grupo vivia desafios singulares frente à intensa movimentação do seu cotidiano. Com isso, acompanhamos a dinâmica da escola com um grupo de 38 professores, que trabalhavam com um total de 924 alunos, distribuídos em oito turmas de $1^{\circ}$ ano, nove de $2^{\circ}$ ano e seis de $3^{\circ}$ ano do Ensino Médio.

A estrutura física da escola organizava-se com os seguintes ambientes, tendo em vista atender sua demanda de alunos: 23 salas de aula, distribuídas em cinco blocos, um laboratório de informática, um laboratório de Ciências Naturais, uma sala com quadro interativo, uma sala de vídeo, uma biblioteca, uma quadra poliesportiva coberta, uma sala de professores, uma sala de planejamento, uma sala da Direção, uma da Coordenação Pedagógica, uma da Orientação Educacional, uma da Coordenação Financeira, secretaria, cozinha, área coberta com palco e cinco banheiros.

A escola organizava-se, há alguns anos, com a proposta de salas ambiente, na qual as salas eram distribuídas entre os professores, ao invés de serem organizadas para cada turma. Assim, na dinâmica do cotidiano, quem trocava de sala, quando tocava o sinal, eram os alunos e os professores 
permaneciam nas suas salas. Essa proposta pode ser considerada como uma inovação, pois poucas escolas adotam esse tipo de organização. Entretanto, na prática havia poucas mudanças efetivas em relação ao processo pedagógico, pois apenas uma sala de aula era organizada de forma a caracterizá-la como um local em que aconteciam aulas de uma determinada disciplina. As demais salas não eram identificadas, não tinham materiais específicos das disciplinas trabalhadas pelos professores e os ambientes contavam apenas com a disposição dos móveis escolares.

A equipe de professores era formada tanto por docentes iniciantes na carreira, quanto por docentes experientes, parte dos quais já estava próximo da aposentadoria. Dentre os professores experientes vários trabalhavam nessa escola há muito tempo. Essas situações integravam a constituição da organização social da escola, na qual,

[...] além dos elementos de sentido de natureza interativa gerados no espaço escolar, se integram à constituição subjetiva deste espaço elementos de sentido procedentes de outras regiões da subjetividade social, como podem ser elementos de gênero, de posição sócio-econômica, de raça, costumes, familiares, etc., que se integram com os elementos imediatos dos processos sociais atuais da escola (GONZÁLEZ REY, 2005a, p. 203).

Assim, as relações sociais do grupo eram constituídas subjetivamente por momentos de afetividade, amizades entre colegas que se encontravam fora do contexto escolar, intrigas, tensões e conflitos. Havia alguns grupos de convivência mais próximos entre si, ao mesmo tempo em que havia professores que estabeleciam pouca relação com os colegas. Ou seja, o grupo que acompanhamos se constituía de forma singular e heterogênea nas tramas complexas da subjetividade social e individual (GONZÁLEZ REY, 2002, 2005a, 2005b, 2013b).

Da mesma forma também eram complexas as relações sociais entre os integrantes da equipe gestora que, na sua maioria, eram profissionais 
com vários anos de experiência na educação e alguns que trabalhavam há muito tempo nessa escola. A Diretora da escola havia assumido o cargo no ano em que realizamos a pesquisa, porém já trabalhava nessa escola há mais de 20 anos, tendo atuado como professora, coordenadora pedagógica e secretária. Considerando que o grupo a considerava como integrante dessa escola, seu ingresso no cargo da Direção se constituiu em um processo tranquilo. Esse cargo não era escolhido pela comunidade escolar, ao invés disso era uma indicação da Secretaria de Educação e do Governador do Estado. Frente a isso, no decorrer da pesquisa, alguns professores e coordenadores colocaram que no ano anterior estavam preocupados com 0 que poderia acontecer com a troca da Direção, mas quando ficaram sabendo quem assumiria se tranquilizaram em virtude de ser uma colega do próprio grupo.

Já o grupo de coordenadores pedagógicos e orientadoras educacionais viviam conflitos nas relações entre si. Enquanto alguns eram mais ativos, criando soluções para os desafios da dinâmica do cotidiano, outros ficavam mais distantes e atuavam na perspectiva da execução de atribuições que Ihes eram solicitadas. Essa circunstância gerava alguns conflitos nas relações entre eles e notamos que a Diretora acompanhava e intervinha em certas situações.

Observamos que, apesar da maneira como a equipe gestora se constituía, a escola tinha um movimento intenso e inúmeras atividades eram planejadas e articuladas, fazendo com que acontecessem, com frequência, projetos, eventos e vivências que dinamizavam o cotidiano escolar. No decorrer da pesquisa acompanhamos momentos como, por exemplo:

- projetos: os professores e a equipe gestora planejavam, no início do ano letivo, os projetos que aconteceriam em cada mês e esse cronograma integrava o Projeto Político-Pedagógico da escola. Os projetos envolviam atividades culturais, esportivas e/ou de conhecimentos, tendo uma importante adesão dos alunos, que se organizavam e envolviam ativamente nas propostas. Havia projetos interdisciplinares e outros que eram planejados somente por um professor. Alguns projetos aconteciam no horário da aula do 
professor e outros aconteciam durante todo o turno, envolvendo as turmas e professores, sendo realizados normalmente na quadra poliesportiva ou na área coberta. Outros ainda aconteciam em outros lugares ou dependências, fora do contexto escolar, e contavam com o apoio da Secretaria de Educação para o transporte ou eram financiados com verbas federais do PROEMI - Programa Ensino Médio Inovador. Uma situação singular que observamos foi o fato de que alguns projetos eram realizados há vários anos consecutivos. Percebemos que esses projetos eram considerados pelo grupo com um valor de importância de constituição da identidade da escola, circunstância que nos possibilita interpretar que se constituíam como expressões da subjetividade social (GONZÁLEZ REY, 2002, 2005a, 2005b, 2013b) dessa comunidade escolar.

Ainda sobre os projetos, observamos que havia um envolvimento muito diverso dos professores em relação aos projetos. A proposição, o planejamento e a coordenação dos projetos se concentravam na atuação de alguns docentes, enquanto o restante do grupo mantinha a prática de aulas regulares com alguns momentos distintos na sua rotina. Apesar disso, nos dias em que aconteciam os projetos que envolviam todas ou grande parte das turmas, observamos que vários professores se envolviam intensamente nas atividades planejadas pelos docentes coordenadores da programação. $O$ ambiente escolar ficava envolto de uma emocionalidade de diversão, alegria e descontração, principalmente nos projetos em que os alunos criavam coreografias, figurinos e cenários para sua participação. Mesmo em meio a essa relação social de envolvimento, parte dos professores ficava alheia e manifestava-se colocando que a escola perdia tempo com os projetos, pois os alunos se dispersavam das aulas ao se envolverem com o planejamento e organização das atividades solicitadas. Assim, a maneira como se teciam as relações sociais por ocasião dos movimentos frequentes demandados pela realização de projetos, evidenciou os conflitos e as tensões gerados no cotidiano;

- eventos que contavam com a participação da comunidade escolar: a rotina da escola também era movimentada por eventos que envolviam a comunidade escolar e havia abertura para incluir atividades não previstas previamente. 
Exemplificamos essa situação com a mobilização e articulação da escola para participar da audiência pública sobre o Plano Estadual de Educação. Apesar de não contar com uma adesão expressiva da comunidade escolar, a equipe gestora e parte dos professores se engajaram na proposta e realizaram debates interessantes a partir do documento encaminhado pela Secretaria de Educação para apreciação. Além de momentos como esse, a comunidade escolar era chamada a participar de momentos específicos, como por exemplo: reuniões de entrega de boletins, em que os professores ficavam à disposição para atendimento de pais e alunos; reuniões do Conselho Escolar, nas quais discutiam e decidiam sobre as prioridades e necessidades da escola e 0 coordenador financeiro prestava contas das verbas recebidas; dentre outros momentos.

Aconteciam também eventos promovidos pelo Grêmio Estudantil, que se constituía como uma instância colegiada ativa no cotidiano da escola. Suas atividades envolviam tanto eventos culturais, artísticos e esportivos, quanto movimentos de conscientização dos alunos, participando de campanhas, trazendo palestrantes, mobilizando os colegas para envolverem-se em manifestações, dentre outras;

- momentos informais de encontro entre os professores: no cotidiano aconteciam com frequência momentos em que observamos os professores dialogando sobre situações das suas aulas. Conversavam sobre os alunos, problemas que aconteciam nas suas aulas, atividades que estavam realizando, planejamento de ações dos projetos que iriam realizar, dentre outros. Além das conversas informais, que aconteciam geralmente na sala dos professores, essa rotina também integrava 0 planejamento semanal, organizado pela coordenação pedagógica de tal forma a contemplar o maior número possível de professores de uma mesma área do conhecimento em cada dia. Essa organização favorecia possibilidades de diálogos e trocas entre os professores, ainda que não plenamente, pois parte dos professores estava em sala de aula e outros usavam esse momento apenas para a realização de atividades burocráticas da docência. 
Outra situação que observamos eram os momentos informais de encontros de confraternizações e comemorações que aconteciam no cotidiano. Parte dos encontros era organizada pela equipe gestora com a ajuda de alguns professores, havendo uma importante adesão do grupo. Outros encontros eram combinados entre os professores que tinham um relacionamento de maior proximidade, como passeios, viagens, refeições que faziam entre as famílias em alguma residência, etc. Consideramos que a maneira como o grupo se relacionava, tanto na escola, como em outros locais, constituía as interações com possibilidades de uma maior abertura para dialogar sobre as situações do cotidiano, pois essa circunstância favorecia que se conhecessem para além das relações profissionais. Nessa perspectiva, interpretamos que tal situação se constituía em outra expressão que integrava a subjetividade social da escola (GONZÁLEZ REY, 2002, 2005a, 2005b, 2013b);

- momentos formais de encontro entre os professores: na rotina da escola observamos também um dinamismo de encontros planejados para a discussão do cotidiano da escola. Uma situação que acompanhamos e consideramos importante destacar era a realização do Conselho de Classe Participativo, que acontecia com três momentos a cada bimestre. Alguns dias antes do Conselho, a Orientadora Educacional organizava os alunos líderes das turmas para realizarem, junto aos seus colegas, uma avaliação da escola, dos professores e da turma, sistematizando as colocações em uma ficha preparada para esse fim. No dia anterior ao Conselho de Classe dos professores, a Diretora, a Orientadora Educacional e alguns Coordenadores Pedagógicos realizavam uma reunião com os líderes das turmas para a socialização dos registros das fichas e debate de possíveis soluções para os problemas identificados. Nesse momento era preparada uma síntese dos principais tópicos debatidos, que era levada ao terceiro momento, o Conselho de Classe entre os professores e a equipe gestora, etapa em que acontecia a avaliação das turmas e dos alunos. Consideramos que esse era um movimento importante na rotina da escola, que possibilitava um canal de comunicação entre todos os integrantes do processo educativo e criava um clima democrático de participação, expressando a subjetividade social da escola (GONZÁLEZ REY, 2002, 2005a, 2005b, 2013b). 
Além desse momento, presenciamos ainda outros momentos formais entre os professores, como por exemplo: encontros denominados como Dia Pedagógico, nos quais aconteciam palestras com convidados externos ou a Diretora conduzia momentos de debates sobre situações e problemas que precisavam ser resolvidos; encontros para o estudo da Base Nacional Comum Curricular, com a participação de convidados externos da Secretaria de Educação; encontros em que aconteceram palestras para os professores; momentos da rotina escolar em que a Diretora ou outro integrante da equipe gestora conduzia reuniões breves para a decisão de algo que demandava certa urgência em relação a uma decisão ou encaminhamento; dentre outros.

Por fim, findamos a apresentação do contexto escolar abordando a situação da greve dos professores, que aconteceu de 5 de Junho a 31 de Agosto, impactando o andamento das atividades planejadas e provocando tensões e conflitos nas relações sociais. O movimento teve uma adesão parcial dos professores da escola. A maioria do grupo aderiu e alguns professores continuaram ministrando suas aulas com um horário diferenciado, preparado pela coordenação pedagógica. Essa situação gerou momentos tensos de discussões entre alguns professores, chegando inclusive a acontecerem agressões verbais e publicações de comentários nas redes sociais. Após a greve alguns relacionamentos continuaram melindrados durante todo o período em que estive na escola.

A paralisação aconteceu em um período em que a escola estava com uma intensa programação de projetos e eventos para a finalização do segundo bimestre. Faltavam apenas algumas semanas para acontecerem os Conselhos de Classe e a rotina das aulas seguia um fluxo regular de conteúdos e atividades avaliativas. O retorno das aulas após a greve provocou desencontros entre o grupo de professores e confusão na organização dos alunos, pois aqueles que não aderiram ao movimento já estavam no terceiro bimestre, enquanto os demais organizavam a conclusão do segundo. Além disso, o calendário de aulas de reposição também aconteceu de maneira desencontrada entre o grupo, em virtude desse mesmo motivo. Com frequência aconteciam falas irônicas entre os dois grupos, que reforçavam as relações tensas no período pós-greve. 
Com o andamento dos meses essa situação ficou mais amena e a escola retomou seu ritmo de trabalho, porém foi possível observar que a disposição tanto dos professores, quanto dos alunos, era diferente em relação ao primeiro semestre. Houve uma sobrecarga de trabalho para todos com a reposição das aulas e com projetos que aconteceram em datas próximas em virtude de não haver mais tempo hábil para uma melhor distribuição no calendário letivo. Alguns eventos e projetos foram prejudicados e não aconteceram, pois houve pouca mobilização dos professores coordenadores. Além disso, a greve também trouxe impactos em relação ao processo de aprendizagem dos alunos. Nos Conselhos de Classe do segundo, terceiro e quarto bimestres várias reflexões foram feitas pelo grupo em relação ao pouco envolvimento dos alunos nas aulas e nas atividades avaliativas, comparando os resultados desse ano com os anteriores. Suas análises se encaminhavam no sentido de encontrarem na greve a explicação principal para um período letivo com tantos problemas.

Portanto, foi nesse contexto escolar intenso, dinâmico e complexo que acompanhamos alguns docentes utilizando instrumentos de pesquisa que nos possibilitaram uma aproximação de elementos constitutivos da sua subjetividade, dentre os quais, conforme explicamos no capítulo metodológico, selecionamos um professor para elaborarmos a construção interpretativa das informações. Assim, na sequência, discorremos sobre o Professor Nícolas e os elementos que integravam a sua constituição subjetiva possibilitando-Ihe viver enquanto sujeito da sua ação docente. 


\subsection{O estudo de caso do Professor Nícolas}

\subsubsection{Nícolas: vida $\Leftrightarrow$ profissão}

- "Mas eu acho que foi o Universo abrindo portas para eu entender, que aqui você vai dar certo!"

Nícolas tinha 50 anos de idade no ano de realização da pesquisa e residia há 20 anos em Palmas - TO. Era natural de São Paulo e mudou-se para Palmas quando se casou com a sua esposa e buscavam oportunidades de trabalho. Sua esposa era advogada, concursada em um órgão público. Eles tinham três filhos adolescentes: um cursava o primeiro ano no Ensino Superior, outro estava no Ensino Médio e a filha concluía o Ensino Fundamental.

No decorrer da pesquisa foi possível perceber a importância do núcleo familiar na vida de Nícolas. Conforme abordaremos no decorrer da construção interpretativa, sua esposa era uma pessoa em quem ele encontrava apoio e segurança, compartilhava sonhos, expectativas, dúvidas e preocupações, refletia sobre o cotidiano e tomava decisões. Nas nossas conversas e entrevistas era frequente sua referência a momentos da rotina familiar em que a esposa participava ativamente nas reflexões que fazia sobre situações do seu trabalho, apresentando opiniões e sugestões.

Igualmente importante era a participação intensa dos filhos na vida de Nícolas. Ele se preocupava com cada filho individualmente, com as suas decisões, com o seu futuro, assumindo efetivamente o seu papel como 
um pai presente. A organização familiar acontecia com a divisão de tarefas entre os integrantes, cabendo a Nícolas o papel de assumir, junto com os filhos, tarefas muitas vezes atribuídas à mulher. Considerando que sua esposa exercia a profissão em um local mais distante da residência e com um horário fixo durante toda a semana, Nícolas tinha na escola um horário organizado de tal forma a conciliar seu trabalho com as tarefas domésticas. Em algumas observações, no final da manhã de quinta-feira, quando encerrava sua carga horária semanal, despedia-se dos colegas dizendo que agora iria para casa para trabalhar. Abordou essa questão também em uma entrevista:

"Acho que foi Confúcio que disse: 'Escolha uma profissão onde você faça o que você gosta e nunca terá que trabalhar nem um dia na vida'. Eu digo pros meus colegas, quando eu vou pra casa quinta-feira, por que eu começo a minha folga na quinta feira à tarde, eu digo: 'Agora eu começo a trabalhar, porque agora vou trabalhar em casa. Até agora estava me divertindo e agora vou trabalhar de verdade! Agora eu vou lavar roupa, vou cuidar da casa."

Além da esposa e dos filhos, abordaremos posteriormente a importância que a mãe de Nícolas teve na sua trajetória de vida, principalmente em virtude da maneira como se colocou e participou em determinados momentos e circunstâncias.

Nícolas exercia a profissão da docência há 20 anos, desde o ano que chegou em Palmas. Antes disso trabalhou em áreas diversas, como fotografia, serviço social, pastor evangélico. Viu-se em uma situação desconfortável quando chegou em Palmas, pois a esposa já tinha seu trabalho garantido e ele não sabia em que iria trabalhar. Em uma das entrevistas colocou o seguinte: " $E$ eu fiquei numa situação assim: o que que eu vou fazer agora ${ }^{\prime 6}$. Encontrava-se em uma situação de incertezas, pois não conseguia visualizar oportunidades no mercado de trabalho a partir da sua formação

\footnotetext{
${ }^{5}$ Dinâmica conversacional sobre os registros no Diário "O cotidiano de um professor" (10 encontro) - 25.11.15.

${ }^{6}$ Dinâmica conversacional com o professor - 28.09.15.
} 
acadêmica que, na época, eram os cursos de Teologia e de Filosofia, conforme expressou: "Porque tenho Curso de Filosofia, mas que tinha feito mais por diversão do que por outra coisa, mais por curiosidade do que por conhecimento"'.

Como não tinha um foco definido para sua atuação, começou a fazer contatos com pessoas da cidade e encontrou alguém que sinalizou uma possibilidade. Havia uma grande carência de professores de Filosofia nas escolas, pois os docentes que atuavam nessa disciplina não tinham a formação específica na área. Frente a essa informação mobilizou-se em busca da oportunidade que aparecia: "Não custa experimentar dar aula de Filosofia, seria como, como eu gosto muito de Filosofia eu pensei que seria um bom desafio e fui pra sala de aula"8. Além do desafio, havia também uma necessidade financeira em relação ao sustento da família: "Acidentalmente eu comecei a dar aulas aqui, porque foi o primeiro emprego que eu achei há 20 anos atrás, quando eu cheguei. Então o que tinha de imediato pra ganhar dinheiro, pra sobreviver, até descobrir outra coisa, era dar aulas"".

A maneira acidental como ingressou em uma profissão que ainda não havia trabalhado, conforme colocou, que não integrava seus projetos de vida, e o desafio que aceitou dadas as circunstâncias e necessidades pessoais vividas naquele momento, parecem ter se constituído em uma situação mobilizadora de envolvimento com a docência. Evidenciamos isso quando colocou o seguinte: "Então não havia se passado pela minha cabeça a possibilidade de virar professor, mas aí eu fui, um, dois anos, três anos, quando percebi já estava mergulhado! [...] E descobri que gosto muito de fazer isso: ${ }^{10}$. Sentia-se mergulhado na profissão, ou seja, seu ingresso na profissão havia mobilizado nele uma forte identificação com a área, algo que ele não esperava, que não havia planejado.

\footnotetext{
${ }^{7}$ Dinâmica conversacional com o professor - 28.09.15.

${ }^{8}$ Dinâmica conversacional com o professor - 28.09.15.

${ }^{9}$ Dinâmica conversacional com o grupo de professores que não participou do movimento da greve - 29.06.15.

${ }^{10}$ Dinâmica conversacional com o professor - 28.09.15.
} 
Além da relação afetiva com a nova profissão, que aconteceu logo nos primeiros anos em que assumiu a disciplina de Filosofia no Ensino Médio, o vínculo com a docência parece ter se tornado ainda mais efetivo quando, após algum tempo de atuação, teve a oportunidade de fazer outra graduação, um curso de licenciatura em Ciências Biológicas. O curso, subsidiado pelo governo, constituiu-se em algo importante e decisivo nesse processo, conforme expressou: "Não perco oportunidade nenhuma na minha vida e não vou perder essa! ${ }^{11}$. Concluído o curso, fez o concurso público estadual, foi aprovado e efetivou-se como professor de Biologia na mesma escola em que atuava, assumindo a docência como algo realmente importante na sua vida:

"Quer dizer, a oportunidade de pensar outra coisa surgiu graças a essa oportunidade [de fazer o curso de licenciatura] que se abriu, mas eu nunca me arrependi de ter começado a dar aula! Adoro dar aula, amo o que eu faço! $E$ eu não escolhi, eu fui escolhido pela profissão, pela situação, né, como acabei de explicar pra você. Mas eu acho que foi o Universo abrindo portas para eu entender, que aqui você vai dar certo! ${ }^{12}$.

Percebemos que os acontecimentos sucessivos ocorridos nos primeiros anos de docência, os quais foram vividos por Nícolas como oportunidades que a vida the presenteou, corroboraram para mobilizar nele uma produção subjetiva de pertencimento à profissão, expresso com destaque quando colocou que se sentia escolhido pela profissão. Considerando as situações apresentadas em relação à história de vida de Nícolas, percebemos que a docência não foi uma escolha pessoal na sua carreira profissional. Antes de trabalhar como professor, não tinha uma profissão definida, não galgava uma carreira em determinada área. As circunstâncias e os percalços das situações vividas o colocaram ante a necessidade de buscar um espaço no mercado de trabalho, tendo o encontro com a docência se constituído em um momento de mudanças na sua vida. Esse encontro fez com que houvesse um

\footnotetext{
${ }^{11}$ Dinâmica conversacional com o professor - 28.09.15.

${ }^{12}$ Dinâmica conversacional com o professor - 28.09.15.
} 
processo de continuidade nas suas atividades profissionais, pois, diferente dos trabalhos em que atuou antes, já exercia a docência há 20 anos.

Relacionado a sua permanência na profissão, outro fato relevante refere-se à situação de que esse tempo na docência foi vivido por Nícolas praticamente todo na mesma instituição, a escola em que realizamos a pesquisa. $O$ início da sua carreira docente deu-se nesse local, assim que chegou a Palmas, sendo interrompido apenas por quatro anos, período em que acompanhou a esposa quando foi transferida para trabalhar no interior do Tocantins. Solicitou transferência e acompanhou-a, dando continuidade ao seu trabalho como professor em escolas nas cidades em que residiram. Quando a esposa foi transferida novamente para Palmas, ele também retornou e voltou a trabalhar na mesma escola.

Frente a isso, seu envolvimento com a profissão constituía-se também por um vínculo afetivo forte com essa escola e as pessoas com quem convivia há vários anos. O grupo docente da escola era formado tanto por professores ingressantes na carreira, como por profissionais mais experientes, assim como Nícolas, dentre os quais vários trabalhavam juntos há algum tempo na instituição. Estes conheciam a trajetória de conquistas, avanços e retrocessos que constituíam a historicidade da escola, sentindo-se orgulhosos em relação a alguns aspectos, ao mesmo tempo em que expressavam saudosismos e preocupações. Inserido nesse grupo, com quem convivia e trabalhava há mais tempo, o sentimento de pertencimento e o vínculo afetivo com a profissão e com a escola se fortaleciam em Nícolas, constituindo a sua subjetividade.

Portanto, considerando as informações apresentadas nesse tópico, podemos inferir que a identificação com a docência constituía-se em um elemento da configuração subjetiva de Nícolas, levando-o a permanecer a duas décadas nesse trabalho e sentir vontade de continuar até a aposentadoria, conforme relatou: "[...] porque eu não consigo me imaginar fazendo outra coisa na minha vida além do que eu faço. É o que eu gosto de fazer e espero fazer 
até me aposentar $p^{13}$. Entendemos que o fato de ter vivenciado outras profissões antes de ingressar na docência possibilitou a Nícolas encaminhar-se para uma escolha profissional em que já tinha outras referências, podendo autoavaliar-se e decidir em relação ao que gostaria de assumir efetivamente para o seu futuro. Frente a isso, consideramos que o processo de descobrir-se como professor constituía-se por processos subjetivos de identificação, envolvimento e pertencimento com a profissão, constituindo-se em elementos que integravam a sua subjetividade.

\subsubsection{Nícolas: um professor $\Leftrightarrow$ um lugar: o lugar de viver a docência}

- "Então começa aqui, é minha vida mesmo!"

Conhecer Nícolas como professor nessa escola e nesse momento da sua vida profissional possibilitou-nos sistematizar uma construção interpretativa na perspectiva de compreender elementos da sua subjetividade em relação ao valor que a profissão tinha na sua constituição, na maneira como vivia, pensava, agia, sentia, se relacionava. No acompanhamento do cotidiano da escola e na convivência com Nícolas, identificamos indicadores que possibilitaram a construção que elaboramos a seguir, entendendo que faziam parte do momento atual vivido pelo professor no período de realização da pesquisa.

Começamos abordando um fato identificado logo no início da pesquisa empírica e que consideramos como um aspecto que singularizava Nícolas no contexto escolar e no grupo de profissionais, o espaço físico onde realizava o seu trabalho, ou seja, a sua sala de aula. Para entendermos o destaque que atribuímos a esse fato, explicamos inicialmente que, já há alguns

${ }^{13}$ Dinâmica conversacional com o grupo de professores que não participou do movimento da greve-29.06.15. 
anos, a escola tinha como proposta realizar o seu trabalho pedagógico por meio da organização de salas ambiente.

Conforme apresentamos no início desse capítulo na descrição do contexto escolar, cada professor tinha uma sala de aula definida e, de hora em hora, ao som do sinal, os alunos trocavam de sala e os professores permaneciam nos seus espaços. Apesar de podermos considerar essa proposta de organização escolar como uma inovação, na operacionalização as salas ambiente eram organizadas e dispostas sem algo que as identificasse quanto às disciplinas que cada professor trabalhava. O que acontecia era apenas uma movimentação diferente entre alunos e professores na sua disposição no espaço físico escolar.

Entretanto, para Nícolas essa forma de organização se apresentou como uma oportunidade para realizar o seu trabalho da maneira como realmente acreditava. Conforme vimos no tópico abordado anteriormente, aproveitar as oportunidades que a vida lhe oferecia se constituía em algo importante para ele. Assim, essa foi mais uma oportunidade que mobilizou em Nícolas a realização de ações para alcançar seus objetivos. Organizou a sua sala de aula como um ambiente em que se sentisse vivo, que representasse a maneira como ele vivia a profissão, como algo integralmente constituidor da sua vida, pois era ali que tudo acontecia. O trecho que apresentamos a seguir expressa esse indicador:

"[...] porque eu dou investimento na sala? Na verdade a realidade é o seguinte: todo professor dessa escola tem o poder de ter uma sala dessas. A escola tem condições pra isso, mas o que a escola não tem é dinheiro pra investir nessa estrutura, ta. Então começa aqui, é minha vida mesmo, ta! Aí a minha esposa, ela sempre me apoiou bastante nisso. Então, quando nós entendemos a proposta da escola, de cada professor ter a sua sala, a única coisa que a escola me ofereceu, abriu as portas pra mim, foi: 'Não, a gente coloca cadeado na porta, a segurança, né'. E aí eu montei essa sala, eu montei essa sala aqui!"14

\footnotetext{
${ }^{14}$ Dinâmica conversacional com o professor - 28.09.15.
} 
No momento dessa fala na entrevista, Nícolas olhou ao redor, como se estivesse recordando momentos vividos no processo de organização do seu espaço de trabalho, demonstrando-se emocionado ao reconhecer o quanto esse lugar significava para ele. Sua identificação com a profissão era tão forte e expressiva, que decidiu personalizar seu espaço físico de tal forma que essa era uma das marcas que o singularizavam no contexto da escola. No momento em que teve apoio da Direção da escola, apoio da sua esposa e condições financeiras no contexto familiar, equipou sua sala de aula e adquiriu materiais que considerava necessários para realizar suas aulas conforme acreditava. Considerando que a docência vive um momento de desvalorização social e precarização do trabalho docente, fazer um investimento pessoal na própria profissão revelava sua mobilização e o forte vínculo que tinha com a profissão, evidenciando um elemento importante na constituição da sua subjetividade.

Destacamos duas decisões de Nícolas que evidenciam a construção desse indicador em relação aos investimentos que fez na sua sala de aula: a compra de dois aparelhos de ar condicionado e a aquisição e organização de recursos didáticos. A manutenção e defesa do espaço construído evidenciavam seu sentimento de satisfação daquilo que realizou, na medida em que mantinha uma postura firme e muita segurança da adequabilidade do que fez e da aplicação de recursos financeiros próprios.

Em relação à primeira decisão, a compra dos aparelhos de ar condicionado, um ambiente climatizado favorecia a disposição das pessoas para envolverem-se com as atividades propostas, pois o clima de Palmas era quente durante todo o ano. As demais salas de aula da escola tinham apenas ventiladores e, além da sua sala, eram climatizados somente os seguintes espaços: salas onde funcionavam os setores pedagógicos e administrativos, como a Direção, a Coordenação Pedagógica, a Orientação Educacional, a Secretaria e a Sala dos Professores; e as salas de apoio pedagógico, como a Biblioteca, o Laboratório de Informática, a sala de planejamento dos professores e uma sala onde foi instalado o quadro interativo. 
Em relação a essa última sala, um dos professores fez um curso para aprender a utilizar o quadro interativo e instalou-se no local, gerando conflitos com os colegas. Esse era um espaço de uso coletivo e os professores, mesmo não sabendo usar o equipamento, queriam usar a sala em virtude de ser um ambiente mais confortável devido à climatização. Entretanto, o professor não liberava a sala, mesmo nos dias em que não utilizava o recurso. Considerava que esse era um direito seu, afinal havia se mobilizado em busca de um conhecimento que os colegas não buscaram e agora merecia pelo menos um ambiente de trabalho mais confortável.

Assim como era conflituosa a relação desse professor com os colegas em virtude do espaço físico, tal situação também acontecia com Nícolas. Em alguns momentos da pesquisa, nas dinâmicas conversacionais e também em observações de reuniões e Conselhos de Classe, aconteceram falas de pessoas que consideravam Nícolas como privilegiado em relação aos demais professores, referindo-se direta ou indiretamente ao privilégio de ter uma sala com melhores condições de trabalho. Sua compreensão sobre essas considerações do grupo era a seguinte:

\begin{abstract}
"Bom, isso até gera um problema, porque isso gera um certo ciúme. Não sei se você já percebeu que isso gera um certo ciúme, gera um certo atrito, por poder fazer esse investimento. Inclusive a Diretora..., estavam me criticando uma vez, a Diretora disse: 'Olha, se vocês quiserem fazer o mesmo que Nícolas fez, eu te apoio totalmente!' Aí quando entra assim, você fazendo seu investimento, que ninguém ta fazendo, aí as pessoas dizem: 'Não vou fazer!' Então não critica quem está fazendo! [...] Não sei, porque eu me pergunto assim: nós temos colegas aqui que eles trabalham de manhã, de tarde, de noite! Então a vida deles é aqui, sabe! Eu acho que poderia fazer isso mesmo, isso aqui, tem gente que... tem gente que talvez não tivesse condições de fazer isso. Ta, eu acho que o fato de ter uma esposa que é advogada ajuda muito, é claro que isso ajuda bastante! Mas há colegas aqui que têm condições financeiras para fazer isso." ${ }^{15}$
\end{abstract}

\footnotetext{
${ }^{15}$ Dinâmica conversacional com o professor - 28.09.15.
} 
Ainda sobre as suas considerações em relação ao grupo de colegas, registrou no completamento de frases:

48. 0 grupo pode não acatar suas ideias.

Esse conjunto de informações da pesquisa parece expressar que, mesmo em meio à situação de conflito com os colegas, Nícolas se fortalecia na maneira como subjetivava a relação entre a profissão e a vida, entendendo-as como uma unidade constitutiva do seu viver, reafirmando a configuração subjetiva de significativa identificação com a docência. Parecia entender que, a partir do momento em que houve uma escolha por essa profissão, ela passava a integrar a vida. Entendia ainda que a vida profissional merecia investimentos pessoais, pois, conforme registrou no completamento de frases, viver era uma busca pela realização pessoal e pela felicidade.

22. Desejo ser feliz.

26. Espero que todos sejam felizes.

52. Meu maior desejo é viver plenamente.

Amparado nesses elementos da sua constituição subjetiva, agia com autonomia, decidindo e intervindo em relação a transformar o espaço da sua sala de aula em um lugar que lhe trouxesse satisfação pessoal e realização profissional. Assim, além da aquisição e instalação de aparelhos de ar condicionado, deixando o ambiente climatizado e mais agradável, tanto para ele quanto para os alunos, seus investimentos também aconteceram em relação a equipar a sala com recursos didáticos para suas aulas. Um dos equipamentos que adquiriu, o qual utilizava em diversas aulas, foi uma televisão para conectar no seu computador. Com esse recurso projetava materiais didáticos que possibilitavam uma abordagem diferenciada dos conteúdos das aulas, como por exemplo, slides, imagens, vídeos, clipes de músicas, etc. 
Outra aquisição foi um microfone sem fio e uma caixa de som, utilizados por ele para falar com os alunos e explicar os conteúdos das aulas, a fim de preservar a sua voz. Essa decisão ele tomou principalmente a partir de uma orientação médica em relação aos cuidados com a saúde vocal, pois em dado momento foi orientado a escolher entre deixar a sala de aula ou providenciar as condições que possibilitassem sua permanência na profissão.

Além dos investimentos financeiros, era visível seu zelo e cuidado com outros aspectos da sala, tornando-a um ambiente tematizado e preparado para receber os alunos em torno dos assuntos de Biologia. Nas paredes da sala estavam expostos vários banners temáticos, os quais eram trabalhos que as turmas dos anos anteriores haviam realizado. Havia também dois bonecos, um do corpo e outro do esqueleto humano, alguns microscópios, vidrarias e produtos de laboratório.

Em conversa informal em um sábado, por ocasião de uma reunião de pais na escola ${ }^{16}$, relatou com pesar o descaso de alguns colegas na maneira como usavam sua sala quando ele não estava na escola. Entendia com tranquilidade que a sala não era sua propriedade, apesar dos investimentos que havia feito nela. Ao invés disso, entendia que era um ambiente coletivo e também poderia ser utilizado pelos colegas, porém esperava que respeitassem e cuidassem do espaço, assim como ele fazia.

Contou que certa vez uma aluna filmou no celular as atitudes desordeiras dos colegas na sala, mexendo nos materiais e equipamentos, enquanto a professora via e deixava acontecer. A aluna disse que filmou para mostrar-Ihe, porque não acreditaria se ela apenas relatasse. Esse fato revelou que havia uma relação de proximidade com os alunos, que eles sabiam o que Nícolas pensava e sentia em relação a sua sala de aula, caso contrário a aluna não teria tido a atitude de levar a informação até ele de forma tão real. Situações como essa em relação ao uso indevido da sala o entristeciam e incomodavam. Na ocasião colocou ainda que gostaria de levar os equipamentos da sala para sua casa, a fim de cuidá-los e garantir que estariam em condições de uso e funcionamento sempre que precisasse.

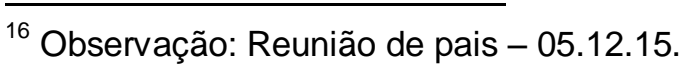


Além das informações apresentadas, a relação afetiva com seu local de trabalho foi expressa com força também no registro que fez no completamento de frases. Ao escrever "47. Minha sala de aula é meu santuário", revelou o quão valioso era para ele cuidar, organizar, preparar e zelar por esse local, pois era ali que ele dizia alcançar e viver a sua realização pessoal e profissional. Expressar-se usando a palavra santuário, juntamente com o conjunto de informações que apresentamos, parece revelar uma produção subjetiva de pertencimento, ao entender sua sala de aula como um lugar de reverência. Nesse local, materializava algo que se fazia sagrado para ele, a sua profissão, evidenciando o quanto esse elemento parecia assumir lugar destacado em sua configuração subjetiva.

Nessa perspectiva, sua colocação no completamento de frases, as falas e as observações das aulas, permitem-nos interpretar que Nícolas subjetivava a profissão assumindo o valor de importância de algo espiritual na sua vida, a qual tinha um lugar especial para acontecer, a sua sala de aula. Parecia haver uma relação sentimental na maneira como vivia a profissão, como se ele se misturasse com o lugar onde acontecia a profissão e, por isso, precisava cuidar, zelar, investir, organizar.

Deste modo, ter tido a oportunidade de personalizar esse lugar parece ter sido uma circunstância que impulsionou uma produção subjetiva de pertencimento à profissão. Trabalhar em uma sala tendo a oportunidade de transformá-la com o seu jeito, com as suas marcas e preferências, trazia para ele uma cumplicidade com a própria profissão, uma relação de indivisibilidade entre a vida e a profissão. Assim, a maneira como vivia, sentia, se posicionava e encaminhava decisões, evidenciava indicadores em relação à constituição subjetiva de Nícolas como um professor que vivia a docência de maneira autônoma e propositiva também na forma como realizava suas aulas e se relacionava com seus alunos, enfoques que abordaremos no próximo tópico. 


\subsubsection{Nícolas: as pessoas e seus motivos}

- “... dar motivos... Eu conheço uma música do Tim Maia,

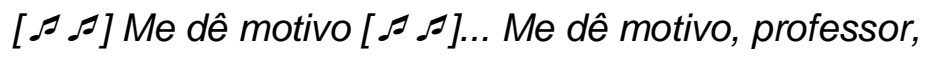
pra eu estar sentado aprendendo! Qual motivo?..."

Considerando a construção interpretativa que elaboramos em relação à importância que a profissão tinha na constituição subjetiva de Nícolas, abordamos nesse momento indicadores relacionados à maneira como realizava o seu trabalho e como aconteciam as relações sociais no cotidiano das suas aulas. No curso da realização da pesquisa percebemos inicialmente que os demais professores da escola referiam-se ao trabalho de Nícolas com ênfase ao privilégio de ele atuar em uma sala climatizada, considerada um local com melhores condições de trabalho, conforme abordamos no tópico anterior. Entretanto, não eram somente questões concretas e objetivas, como ter uma sala climatizada e com alguns recursos e equipamentos que faziam com que houvesse uma intensa relação de Nícolas com a profissão.

Nas observações das suas aulas foi visível, inicialmente, que havia uma expressiva preocupação com o planejamento, pois considerava importante que o professor zelasse pela realização de uma boa aula, o que implicava organizar-se previamente para realizar o seu trabalho. Entretanto, conforme veremos no decorrer da construção interpretativa desse tópico, a relevância do planejamento, para ele, não estava na questão puramente técnica da organização das suas aulas. Planejar era importante porque significava preparar-se para o momento do encontro com os alunos, algo evidenciado tanto na organização das etapas da aula, ou seja, havia um começo, um desenvolvimento e uma finalização, quanto na preparação dos recursos didáticos para as abordagens de cada conteúdo. Destacamos a fala em uma das entrevistas, na qual ele relatou sobre a necessidade que teve de 
mudar uma determinada aula, em que evidenciamos a importância atribuída ao planejamento e à organização:

"[...] porque no caso da aula ali, eu estava preparado pra trabalhar um conteúdo, e eu sou uma pessoa que eu gosto muito que as coisas aconteçam como eu planejei! Eu fico meio, fico muito... primeiro eu fico muito frustrado quando as coisas não acontecem como eu planejei que aconteçam, mas situações como essa levam a entender que há uma necessidade [de mudar o planejamento]."17

Além dessa colocação, visualizamos a construção interpretativa desse indicador também em respostas registradas nos seguintes indutores do completamento de frases:

9. Sofro quando não consigo atingir metas.

18. Minhas expectativas são mensuráveis.

37. Tentarei conseguir atingir meus objetivos.

Percebemos que havia uma implicação emocional em relação a alcançar os resultados do seu planejamento, pois expressou que sofria e se frustrava quando as situações que aconteciam o distanciavam dos objetivos para os quais se propunha. Tal emocionalidade mobilizava nele a articulação de ações em prol dos seus objetivos, a realização de estratégias metodológicas diversificadas e a elaboração de recursos didáticos e tecnológicos. Isso porque não queria sofrer, não queria frustrar-se com um resultado não alcançado em virtude de algo que ele considerava que poderia ter realizado e/ou preparado anteriormente, ou seja, de algo que considerava estar ao seu alcance.

Esse movimento de mobilização pessoal e articulação de ações, superando obstáculos que vários colegas consideravam como limites para realizar um trabalho pedagógico diferenciado, foi analisado também em

17 Dinâmica conversacional sobre os registros no Diário "O cotidiano de um professor" $\left(1^{\circ}\right.$ encontro) -25.11 .15 . 
pesquisa realizada por nós anteriormente (GALLERT, 2010; GALLERT; TACCA, 2012). O estudo mostrou os processos subjetivos de uma professora que encontrava e criava alternativas de enfrentamento ante as adversidades do seu trabalho, evidenciando uma força pessoal de superação, caracterizada por elementos subjetivos como: "a busca pessoal pela realização de um bom trabalho; a força pessoal que tinha em si no enfrentamento das dificuldades, levando-a a assumir como suas as responsabilidades pela intervenção pedagógica a ser realizada para que houvesse mudanças; e a não aceitação do fracasso" (GALLERT; TACCA, 2012, p. 26).

Nessa perspectiva, acompanhamos situações em que Nícolas também assumia posicionamentos ativos nas suas aulas, criando estratégias para resolver questões que ele observava, identificava e o preocupavam. Destacamos uma situação que preocupava não só a Nícolas, mas também os demais professores da escola: o desinteresse dos alunos em relação às aulas, aos conteúdos e aos estudos. Frente a isso, observamos, no acompanhamento do trabalho de Nícolas, que um dos recursos que planejava e usava com frequência nas suas aulas era a música, apresentada por meio de videoclipes na televisão. Em alguns momentos a música estava relacionada com o tema da aula, noutros era uma estratégia de recepção aos alunos, com um cantor ou grupo musical que ele sabia que apreciavam. Quando Nícolas escolhia uma música que os alunos gostavam, era visível o seu envolvimento, pois já entravam na sala cantando e dançando.

Além disso, o envolvimento dos alunos com essa estratégia acontecia também por meio da indicação de músicas para o professor. Essa situação foi observada quando, ao trabalhar determinado conteúdo, o professor finalizou a aula solicitando sugestões de músicas que eles conheciam e que tinham relação com o assunto estudado, a fim de que trouxesse nas próximas semanas. Na ocasião comentou com os alunos sobre uma música que alguém havia sugerido em outra turma, que ele não conhecia, mas que iria procurar, pois parecia ter uma relação direta com o assunto em estudo ${ }^{18}$. Essa estratégia criava um clima de proximidade entre o professor e seus alunos. A identificação

${ }^{18}$ Observação: Aula do Professor Nícolas - 01.10.15. 
do docente e dos estudantes com a música os fazia alcançar a motivação e o envolvimento a partir desse recurso de que o grupo gostava.

Considerando os aspectos analisados nos tópicos anteriores, nos quais visualizamos que havia uma relação significativa entre a vida e a profissão de Nícolas, o fato de trabalhar com adolescentes e ter filhos que estavam nessa faixa etária, entre 15 e 17 anos aproximadamente, parecia ser algo que também favorecia a realização de um trabalho mais próximo dos seus alunos. Assim, aproveitava situações vividas no seu cotidiano familiar para planejar as aulas e, com isso, aprimorar o seu trabalho. Exemplificamos a presença da complementaridade entre questões familiares e profissionais, em relação ao planejamento das aulas, destacando uma colocação de Nícolas em uma das entrevistas:

"Eu uso uma música, eu uso uma aula prática. São estratégias pra seduzir o adolescente, porque o nosso aluno, o nosso público do Ensino Médio são os adolescentes. $O$ adolescente, ele é exigente, e tem professor que não pensa nisso! Eu entendo um pouco melhor porque, além de professor, eu tenho três adolescentes. Então eu percebo como os meus adolescentes [Nesse momento referia-se aos seus filhos.] são preguiçosos, como todo adolescente, faz parte da adolescência. Como eles são indolentes! Eles querem que você faça, mas eles não querem se oferecer. Faz parte da adolescência! Nós também já fomos assim, ta! E como eles querem, eles querem uma novidade, coisa diferente, pelo amor de Deus! Então quando você fizer alguma coisa diferente, ele te responde um pouco."19

As colocações que destacamos revelam como Nícolas era uma pessoa atenta aos detalhes do cotidiano e às manifestações das pessoas, tanto no seu trabalho quanto na sua vida familiar. Vivia o cotidiano familiar de relação com os filhos com olhar atento àquilo que poderia sinalizar aspectos a considerar no momento do planejamento e na realização das suas aulas. Ao mesmo tempo, vivia a profissão percebendo que os seus colegas professores não valorizavam características da faixa etária dos adolescentes, situação que

19 Dinâmica conversacional com o professor - 28.09.15. 
provocava um distanciamento entre ambos e dificultava alcançar os objetivos das aulas.

Além disso, considerando que planejar e alcançar os objetivos eram situações importantes para Nícolas, podemos inferir também que havia uma produção subjetiva de unicidade e complementaridade entre a família e o trabalho, o que possibilitava a ele realizar estratégias pedagógicas de aproximação com seus alunos, na perspectiva de alcançar os resultados para os quais se propunha. Entendemos que esse era um dos elementos constituidores da sua subjetividade, que mobilizava nele ações e atitudes na perspectiva de evitar ou minimizar a frustração quando não conseguia alcançar as metas que estabelecia para o seu trabalho como professor.

Assim, compreendemos tal circunstância como uma produção subjetiva em virtude de que estava presente a tecitura complexa entre suas emoções e seus pensamentos, aspecto mobilizador de decisões e ações na prática pedagógica. Inferimos que se evidenciava o caráter gerador da sua presença como um professor sujeito, que se articulava na busca por possibilidades frente aos desafios do cotidiano. Nessa perspectiva, concordamos com Mitjáns Martínez (2003) quando argumenta que

[...] la acción pedagógica del profesor, en su condición de sujeto, estará mediatizada por una parte, por el conjunto de recursos subjetivos que lo caracterizan en su constitución histórica, entre ellos por sólo citar algunos, sus motivaciones, capacidades, representaciones, valores, expectativas, projectos, y por outra por las carcaterísticas de los espacios sociales e interactivos donde sus acciones tiene lugar y el significado y el sentido que asumen para él en vínculo inseparable y procesual con su propia acción. (p. 143)

Relacionando os argumentos da autora com a construção interpretativa que elaboramos, as colocações de Nícolas evidenciaram outro aspecto de destaque na análise da sua constituição subjetiva. Enquanto falava sobre as estratégias metodológicas que considerava importantes para suas aulas, colocou que eram "estratégias pra seduzir o adolescente". Sua fala 
trouxe implícita a compreensão que ele tinha de que era imprescindível que o professor pensasse as suas estratégias em função dos alunos com os quais trabalhava. Havia uma razão de ser para o trabalho do professor, o seu aluno. As intervenções pedagógicas não se garantiam por si mesmas, não eram elas somente planejadas tecnicamente e/ou acontecendo de maneira organizada que possibilitariam alcançar resultados satisfatórios no seu trabalho.

Assim como as estratégias metodológicas, igualmente os recursos didáticos e tecnológicos não eram para Nícolas uma resposta única e definitiva para os desafios educacionais contemporâneos. Para além disso, era preciso entender que havia algo permeando o processo de operacionalização das estratégias e a utilização dos recursos, ou seja, a maneira como aconteciam as relações sociais vividas entre professores e alunos, que poderia tanto potencializar quanto fragilizar o processo de ensino e aprendizagem. Assim, as intervenções do professor e os recursos utilizados precisariam acontecer na perspectiva de promover os processos de aprendizagem e desenvolvimento dos alunos, pois estes eram a razão maior de ser do trabalho de uma escola.

Além disso, ao utilizar a palavra seduzir, Nícolas explicitou também a compreensão de que o processo de ensino e aprendizagem envolve uma relação de proximidade e emocionalidade entre professores e alunos, que não se limita somente na transmissão de conhecimentos previamente definidos e organizados no momento do planejamento. A construção interpretativa das informações nos possibilita inferir que ele compreendia que há algo a mais, há um envolvimento emocional entre professores e alunos, permeado pelo conhecimento abordado, o qual possibilita que aprender o conteúdo alcance uma significação para a vida do aluno.

Parecia estar implícita a consideração da importante relação entre cognição e afeto nos processos subjetivos da aprendizagem em um contexto relacional (TACCA; GONZÁLEZ REY, 2008; TACCA, 2004, 2006, 2009, 2015; GONZÁLEZ REY, 2004b, 2009b, 2012, 2014b) A sedução, nesse caso, implicava em um processo de conquista de uma pessoa em relação a outra, ou seja, do professor para com os seus alunos, utilizando-se, para isso, de 
estratégias e recursos. Frente a isso, entendemos que essa construção interpretativa sinaliza uma produção subjetiva de segurança e clareza em relação ao foco do seu trabalho, o qual estava nitidamente centrado no seu aluno.

Nessa perspectiva, visualizamos uma relação de proximidade entre esse elemento da constituição subjetiva de Nícolas com os argumentos de Tacca (2006, p. 48) ao argumentar sobre o conceito de estratégias pedagógicas, pois são estratégias planejadas e realizadas pelo professor que estão

[...] acopladas, enraizadas e nitidamente implicadas com as relações sociais estabelecidas. Nesse sentido, elas seriam recursos relacionais que orientam o professor na criação de canais dialógicos tendo em vista adentrar o pensamento do aluno, suas emoções, conhecendo as interligações impostas pela unidade cognição-afeto. Nesse sentido, seriam recursos, principalmente pessoais, que implicam captar o outro, dispor-se a pensar com o outro para fazer gerar as significações da aprendizagem.

No decorrer das observações das aulas percebemos que havia um esforço de Nícolas para entender os pensamentos e as emoções dos seus alunos, para criar estratégias que the permitissem uma aproximação do universo dos adolescentes, ou seja, ele criava recursos relacionais para captar seus alunos, conforme argumenta Tacca (2006). Ele entendia que era imprescindível o papel do professor como aquele que conhece os motivos que movem o aluno para aprender e, para isso, assumia uma postura investigativa em relação aos interesses e necessidades dos alunos. Explicitou seu posicionamento a esse respeito da seguinte maneira em uma das nossas conversas:

Professor: [...] Então eu acho que o grande desafio do professor hoje na sala de aula é ser motivador, porque o aluno já não tem mais uma propensão a gostar de Biologia, porque é muito, tem muitos termos em grego e etc. Então a minha primeira função, em sala de aula, é motivar meu 
aluno. A segunda é tentar ensinar alguma coisa pra ele. Se eu não conseguir ensinar nada, eu quero que pelo menos eu saiba que ele ta motivado, por favor, sair da minha sala motivado!

Pesquisadora: E o que significa motivar, para você?

Professor: É motivo! Eu conheço uma música do Tim Maia 'Me dê motivo'! [Nesse momento o professor cantou esse trecho da música.] Me dê motivo, professor, pra eu estar sentado nessa cadeira aprendendo! Qual motivo? 0 que vai me mover, não é isso? Porque a palavra motivação vem de mover, não é isso, de te mandar pra frente. O que vai me mover a fazer isso, a aprender mais. $E$ aí entra o papel do professor, não o repassador de conhecimento, que antigamente o professor era repassador de conhecimento. Hoje eu entendo que isso é uma besteira, que não tem a menor, a menor lógica! $O$ professor não é um repassador de conhecimentos, o professor simplesmente é um coordenador do processo, ta. Eu acho que se você..., eu posso ensinar a teoria pro meu aluno, mas vou tentar mostrar pra ele, mostrar o que significa! Cara, sabe o que significa? Significa que o pensamento científico é o que nos dá ideia de que nós possamos ser alienígenas povoando esse planeta, né! Isso pode ser legal! Isso pode ser interessante, né! Então quando ele pensar na origem da vida e a proposta do conteúdo, ta, que é um conteúdo muito chato, ele vai lembrar: 'Opa, a teoria do alienígena!' Eu, eu passo pra eles na sala de aula, entendeu? Então, como que um negócio desse pode ser chato?! Não pode! Como que um negócio desses pode não ser interessante quando se trata da origem! Como é que o ser humano, não é isso, vim parar aqui onde eu tô hoje, como tudo aconteceu, como cheguei a isso aqui? Então isso não é interessante? Isso é muito interessante! Então esses recursos podem ajudar você a despertar interesse neles. ${ }^{20}$

O trecho que apresentamos revela, na parte final, a empolgação de Nícolas ao explicar como trabalhava um assunto do seu conteúdo, as teorias sobre a origem da vida. O tema era especial para ele, dada a compreensão ampla que tinha em virtude da sua formação em Filosofia, o que Ihe permitia uma abordagem não somente biológica, mas também reflexiva e crítica. Usava estratégias para tornar o conteúdo divertido, na tentativa de que os alunos se lembrassem das aulas a partir de uma abordagem lúdica. Estratégias pedagógicas como essa possibilitavam alcançar a relação cognição-afeto por meio de recursos relacionais (TACCA, 2006), pois

\footnotetext{
${ }^{20}$ Dinâmica conversacional com o professor - 28.09.15.
} 
adentrava o universo dos alunos, instigando sua motivação e seu envolvimento para aprender um determinado conteúdo.

A compreensão de Nícolas sobre o papel do professor, como motivador e coordenador do processo de ensino e aprendizagem, a partir do qual realizava o seu trabalho, mobilizava nele o planejamento e a efetivação de intervenções que geravam um processo de reciprocidade na maneira como ele e seus alunos se envolviam com as propostas das aulas. A maneira como Nícolas vivia o seu cotidiano parecia gerar um processo subjetivo de comprometimento e motivação com o seu trabalho, que se intensificava a medida em que observava a maneira como seus alunos participavam das suas aulas. Mantinha-se atento às manifestações de envolvimento, indiferença e distanciamento dos alunos, mobilizando-se e articulando-se para alcançar os resultados que esperava. Essa construção interpretativa nos possibilita visualizar uma aproximação com a compreensão do aluno enquanto sujeito que aprende, conceito desenvolvido por González Rey (2006, 2009b, 2012) na sua teoria, o qual explica da seguinte maneira:

A ideia do sujeito que aprende pretende trazer ao cenário da sala de aula todos os processos subjetivos que se constituem nas diferentes configurações subjetivas que se organizam no complexo contexto da vida escolar e que podem estar associadas a eventos muito diferentes dentro da escola. (idem, 2012, p. 35, grifo nosso)

Nesse sentido, era evidente em Nícolas a necessidade de sentirse motivado profissionalmente para motivar o seu aluno a aprender. Havia uma relação afetiva forte de Nícolas com aquilo que é a essência do trabalho de um professor, o envolvimento do aluno com as estratégias propostas e coordenadas pelo professor e a aprendizagem produzida e elaborada a partir dessas vivências. A maneira como Nícolas subjetivava a relação professoraluno instigava nele uma sensibilidade na perspectiva de ver, perceber e sentir a reciprocidade dos alunos para com as suas aulas. Assim, observamos que Nícolas se mobilizava na perspectiva de realizar aulas que instigassem a participação dos alunos, pois isso instigava nele próprio a realização pessoal 
com a profissão. Entendemos que parecia haver um processo subjetivo de recursividade entre a motivação do professor com a dos seus alunos, gerando processos de subjetividade social de envolvimento mútuo nas aulas.

Nesse ínterim, uma das situações que ele sabia que inquietava e preocupava diversos alunos eram suas perspectivas de futuro e seus projetos de vida. Considerando a convivência com os filhos adolescentes, a faixa etária dos alunos e o fato de cursarem o Ensino Médio, ele demonstrava-se atento às manifestações do cotidiano e preocupava-se em relação a como poderia ajudálos nesse momento complexo de tomada de decisões. Assim, consideramos que havia uma preocupação em relação a como os adolescentes articulavamse nas suas escolhas de futuro. Isso porque, conforme observamos no acompanhamento das aulas, suas preocupações com tal questão mobilizavam nele ações e intervenções no seu trabalho pedagógico. Percebemos que, sempre que possível, ele organizava o planejamento dos seus conteúdos relacionando-os com a vida profissional e a tomada de decisões imbricada nesse processo.

Sua preocupação e envolvimento pareciam ter relação com a sua história de vida, pois na sua adolescência ele não teve orientações em relação a como fazer a sua escolha profissional ou como poderia descobrir-se sobre a área de atuação com a qual se identificava. Seguiu a vida com as oportunidades e circunstâncias que foram acontecendo e, somente após ter ingressado na docência, já com trinta anos de idade, encontrou-se profissionalmente. Considerando que não teve essa orientação na trajetória da sua vida pessoal, situação que o levou a encontrar-se tardiamente na sua escolha profissional, sentia-se responsável pelos alunos, conforme colocou:

"Mas teria me ajudado muito se eu tivesse tido um professor que fizesse isso comigo! Então, por isso, eu acho tão importante fazer isso com os meus alunos, com os meus filhos" ${ }^{\prime 21}$.

${ }^{21}$ Dinâmica conversacional sobre os registros no Diário "O cotidiano de um professor" $\left(1^{\circ}\right.$ encontro) - 25.11.15. 
Assim, as circunstâncias vividas na sua história constituíram em Nícolas uma produção subjetiva de envolvimento e responsabilização com as escolhas e os projetos de futuro das pessoas a sua volta, principalmente os adolescentes, buscando acessar as configurações motivacionais dos seus alunos. Sentia-se responsável por provocar reflexões, fazer questionamentos e possibilitar o acesso a informações que poderiam orientar seus alunos nas suas escolhas, a fim de ganharem tempo com decisões mais assertivas. Nessa entrevista colocou ainda que se considerava uma pessoa de sorte por ter tido a oportunidade de encontrar-se profissionalmente, mesmo após vários anos em que já estava no mercado de trabalho. Expressou sua preocupação com o fato de que várias pessoas começavam a sua vida profissional e depois não tinham essa oportunidade ou não tinham coragem para recomeçar, fazer um novo curso ou voltar a estudar, e acabavam frustradas o resto da vida.

Noutra ocasião, em um diálogo na sala dos professores ${ }^{22}$, relatou sobre uma conversa que teve com o filho de um amigo quando percebeu que ele estava insatisfeito com o curso de graduação que acabara de começar. Sentiu que precisava levá-lo a refletir se tinha feito a melhor escolha, tomando como referência possibilitar a ele que identificasse o que realmente gostava de fazer, em qual área de atuação poderia se sentir realizado e feliz. A maneira como o rapaz respondeu-Ihe como estava o andamento do curso de graduação alertou-Ihe de que havia algo errado, e, como ainda estava no início dessa nova etapa da sua vida, esse era o momento propício para uma conversa e uma intervenção na perspectiva de uma orientação profissional. Relatou que dedicou em torno de trinta minutos nessa conversa e, ao final, o rapaz mostrouse agradecido, pois se sentia mais seguro e iria pensar sobre a melhor decisão em relação a sua trajetória na universidade. O fato relatado por Nícolas mostrou seu envolvimento e responsabilização ante uma situação em que percebeu uma oportunidade para contribuir com o futuro de um adolescente, a fim de que vivesse um processo de escolha profissional com mais segurança, comparado com a maneira como ele próprio viveu.

\footnotetext{
${ }^{22}$ Observação: aula do professor - 16.11.15.
} 
Em relação a essa situação, identificamos um aspecto contraditório na subjetividade de Nícolas. Ele gostava da profissão da docência, assumia o papel de instigar seus alunos e conhecidos a pensarem sobre o seu futuro, sobre o que efetivamente gostavam de fazer, na perspectiva da sua realização pessoal e felicidade. No entanto, com o seu filho agiu de maneira diferente. Em uma conversa na sala dos professores ${ }^{23}$, relatou que o filho gostava muito da área de história e queria fazer a graduação de Licenciatura em História. Apesar de saber que essa era a área de atuação profissional que traria realização profissional para o seu filho e de preocupar-se em provocar os adolescentes a descobrirem-se, instigou seu filho a buscar outra área de atuação profissional, pois não queria que ele fosse professor.

O caráter contraditório da sua subjetividade se expressou com força, pois ele gostava da docência, porém não queria que o filho seguisse essa profissão em virtude da desvalorização e do desgaste físico e emocional despendido para realizar um trabalho satisfatório. Conseguiu convencer o filho a prestar vestibular para o curso de Direito, argumentando que nessa área também teria a oportunidade de vivenciar duas situações que se identificava e gostava: a leitura e os estudos sobre história.

Assim como orientou seu filho e o rapaz a que nos referimos acima, Nícolas sentia a necessidade de provocar seus alunos a reflexões desse tipo, antes que iniciassem sua vida universitária ou profissional, logo após o Ensino Médio. Essa situação mobilizava nele o planejamento de determinadas abordagens dos conteúdos das suas aulas, demonstrando sua autonomia no processo de tomada de decisões no seu trabalho. Dessa forma, ao enfocar, por exemplo, assuntos relacionados com o funcionamento do sistema nervoso, decidiu começar falando sobre a teoria das inteligências múltiplas, de Howard Gardner. Dedicou algumas aulas para esse enfoque e só depois trabalhou com os conceitos previstos na sua proposta curricular ${ }^{24}$. Sobre essa situação fez os seguintes registros no Diário "O cotidiano de um professor":

\footnotetext{
${ }^{23}$ Observação - 29.10.15.

${ }^{24}$ Observação: aula do professor - 16.11.15.
} 
"09.11.15 - Iniciei hoje um novo conteúdo da Biologia que é tecido nervoso e decidi começá-lo de uma forma prática abordando temas como inteligência e cérebro.

Os alunos da Turma 13.01 que têm se mostrado mais apáticos do que as demais turmas, mostraram uma melhor receptividade a esse novo conteúdo."

"10.11.15 - Dia surpreendente de aula, muita vibração no conteúdo cérebro e inteligência humana. Muitas perguntas, questionamentos e dúvidas. O sucesso de uma aula é determinado pela dúvida que ela deixa na cabeça do aluno e não na resposta obtida. Parece que tive êxito."

"16.11.15 - Para uma melhor compreensão do conteúdo tecido nervoso e cérebro decidi trabalhar com a Teoria das Inteligências Múltiplas do Gardner. Alguns alunos me procuraram após a aula para conversar sobre a relação de suas inteligências e a escolha profissional que farão em breve, o que mostrou que houve algum resultado positivo."

Em relação a esses registros, chamou-nos atenção o fato de ele ter sistematizado três registros sobre um mesmo fato no decorrer de uma semana $^{25}$. Tal situação revelou sua implicação emocional com a maneira como planejou e realizou as aulas sobre esse conteúdo, percebendo e acolhendo o envolvimento dos alunos com as propostas. Planejar com cuidado era algo valioso para ele, pois compreendia que o seu papel como professor não era somente ensinar os conteúdos, conforme colocado anteriormente. Mais importante do que isso, seu papel era motivar seus alunos, o que significava, para ele, instigar os motivos que os movessem na perspectiva da aprendizagem. Assim, ao realizar esse tipo de abordagem no conteúdo da sua proposta curricular, entendemos que Nícolas estava criando estratégias pedagógicas, ou seja, recursos e canais dialógicos para adentrar os pensamentos e as emoções dos seus alunos, conforme defende Tacca (2006).

Ligado a isso, essas questões evidenciam o quanto planejar e vivenciar aulas desse tipo era importante para Nícolas, pois aconteciam e eram

25 Esse fato chamou-nos atenção em virtude da maneira como ocorreu o processo metodológico do Diário de Bordo. O professor recebeu o caderno e ficou com o material no decorrer de oito semanas. No decorrer desse período fez quatorze registros, sendo três deles relacionados ao fato que estamos analisando. 
realizadas por ele em função de alguém, o aluno. Entendemos que essa situação nos possibilita inferir que suas intervenções eram criativas, pois, conforme Mitjáns Martínez (2006), a expressão da criatividade no trabalho pedagógico se manifesta "como as formas de realização deste que representam algum tipo de novidade e que resultam valiosas de alguma forma para a aprendizagem e o desenvolvimento dos alunos" (p. 70). Assim, segurança e a clareza de que os alunos eram o centro do seu trabalho mobilizava nele reflexões, ações e intervenções ante as circunstâncias em que percebia que era necessário colaborar em prol dos seus alunos. Ao realizar esse trabalho, compreendemos que se fazia presente o caráter gerador da sua postura enquanto sujeito, pois havia uma compreensão de que atuava em uma profissão que poderia contribuir para um futuro melhor para a juventude.

Articulado a isso, Nícolas sentia-se responsável por esse processo, conforme analisamos anteriormente. O movimento subjetivo de responsabilização pelo processo de aprendizagem e desenvolvimento dos seus alunos evidenciava um elemento importante da sua configuração subjetiva, ou seja, a importância do outro quando se estabelece uma relação social de alteridade. Percebemos que ele atribuía um valor significativo à contribuição do outro como participante e colaborador na vida das pessoas. Principalmente um outro mais experiente, questionador, provocador de reflexões, que busca captar os motivos implicados nas relações sociais e que impulsiona processos de tomadas de decisão que podem instigar e mover na perspectiva de outras possibilidades. A maneira como subjetivava o cotidiano da sua profissão encaminhava-se na perspectiva do destaque que Tacca (2004) atribui ao docente, quando argumenta que

[...] não podemos deixar de considerar a importância da posição do professor diante do grupo constituído com seus alunos, que lhe permite organizar o ambiente social de forma a possibilitar condições para a vivência de momentos de intimidade, criando oportunidades para os processos de desenvolvimento. (p. 110) 
Nessa perspectiva, considerando a sua maneira de ser, agir e viver a profissão junto aos alunos, Nícolas sentia-se importante na prospecção de possibilidades de futuro na vida dos mesmos. Suas decisões e ações evidenciavam sua compreensão sobre o valor dos impactos que um professor pode ter na vida do seu aluno, assumindo para si o papel do outro questionador e provocador de reflexões junto as suas turmas. Tal circunstância nos possibilita interpretar que poderia haver uma produção subjetiva do professor em relação ao valor que a relação cognição-afeto assume no processo de aprendizagem e desenvolvimento dos alunos (TACCA; GONZÁLEZ REY, 2008; TACCA, 2004, 2006, 2009, 2015; GONZÁLEZ REY, 2004b, 2009b, 2012, 2014b).

Entendemos que o fato de assumir essa postura do outro como alguém importante, que pode contribuir com o processo de vir-a-ser das pessoas, tinha uma íntima relação com a sua história de vida. Relatou, nas nossas conversas, que viveu situações em que teve a presença marcante de alguém, um outro, que o provocou à reflexão, questionou e oportunizou situações importantes na sua trajetória de vida. Momento especial da pesquisa foi o relato de uma situação da infância, em que a presença de um senhor, a quem chamava de "mentor", o inseriu no universo dos livros. Nícolas atribuía a esse outro o importante papel de ter instigado nele o processo de descobrir-se em relação ao desenvolvimento da "inteligência lingüística", a qual considerava imprescindível para o exercício da sua profissão. Sobre isso relatou, com detalhes e carinho, relembrando fatos da sua infância e adolescência:

"[...] Eu era um garotinho de Ensino Fundamental e eu passava... Ontem a noite eu estava pensando nisso $?^{26} \ldots$ A minha casa ficava muito longe do colégio que estudava, eu tinha que atravessar uma avenida enorme, era uma caminhada de quase meia hora. E eu passava todos os dias na frente de um bazar, Bazar Marinho, na época, de um senhor aposentado, Luiz Gonzaga. Não esqueço dele nunca, porque pra mim ele foi o mentor! $E$ a gente era muito pobre e não

\footnotetext{
${ }^{26} \mathrm{~A}$ colocação de Nícolas "Ontem a noite eu estava pensando nisso!" revelou o quanto ele estava envolvido com a pesquisa. Tanto na escola quanto em outros locais, pensava, refletia e relembrava situações relacionadas aos enfoques suscitados a partir dos procedimentos metodológicos nos quais participava.
} 
tinha os brinquedos que tem hoje, mãe comprar mochila e aquelas coisas de colocar lápis e estojo, essas coisas não tinha! Minha mãe não tinha condições de comprar essas coisas! Então a gente passava na frente. Naquela época vendia Linha Corrente nos armarinhos, que vinha em caixinhas de papelão. E ele basicamente vendia isso pra viver. Então eu tinha muita caixinha, ele dava caixinha pros meninos que passavam lá, pobres. Então eu comecei a entrar em contato com Luiz Gonzaga pedindo caixinhas:

- 'Tem caixinha de linha?'

- 'Tem!'

Eu usava as caixinhas de linha pra colocar meus lápis. E como se tornou muito rotineiro, o Luiz Gonzaga, que tinha muito tempo de sobra porque era aposentado, ele começou a conversar comigo. Quando tinha um tempinho antes da aula, ele começou a conversar comigo e ele começou a conversar sobre livros. Livros, entendeu!

- 'Você lê? Você já leu alguma coisa? E se eu te emprestar um livro, você lê?'

- 'Leio!'

Eu lembro até hoje o nome do livro, eu nunca me esqueci: $A$ Ilha Perdida! Ele me emprestou o primeiro livro. Nunca tinha lido um livro na vida! Aí eu fiquei meio perdido! Uma semana depois eu devolvi!

- 'Gostou?'

-'Muito!'

- 'Se eu emprestar outro, você lê?'

-'Leio!'

E começamos um relacionamento além das caixinhas, nós começamos um relacionamento literário, que durou anos! $E$ depois..., foi meu mentor literário, entendeu? Ele me iniciou no mundo da literatura! [...] Depois ele foi me jogando alguma coisa mais, foi jogando Agatha Christie, depois ele foi para outros autores. Ou seja, já saiu do nível do banal, já começou a mandar a literatura psicológica, ele começou....

- 'Ta gostando? Eu vou dar uma literatura francesa pra você ler.'

Naquele momento eu estava viciado! Tudo que ele passava eu lia! Conheci os clássicos da literatura com ele..., ele foi o meu mentor até que eu terminei meus estudos, saí da cidade em que eu morava, perdi contato com ele, mas nunca esqueci. Então ele me iniciou na literatura. Então, como eu já tinha uma inteligência linguística iniciada da literatura, então isso aí foi impactante! Então eu percebi em dado momento que tudo o que eu quisesse da minha vida tinha que estar relacionado com letras, com livros, com palavras, com ideias. $E$ as escolhas eu fiz a partir de então, até chegar onde eu estou hoje, eu acho que eu não faria nada diferente, ta. Eu acho que eu faria, por exemplo, talvez eu tivesse me tornando professor antes do que eu me tornei, talvez sim."27

\footnotetext{
${ }^{27}$ Dinâmica conversacional sobre os registros no Diário "O cotidiano de um professor" $\left(1^{\circ}\right.$ encontro) -25.11 .15 .
} 
O relato que apresentamos nos possibilita, inicialmente, articular uma construção interpretativa com o primeiro tópico de análise do caso de Nícolas, no qual apresentamos indicadores relacionados ao seu processo de escolha profissional. Tanto a docência, quanto as demais atividades profissionais que ele exerceu antes de lançar-se no desafio de assumir o magistério, estavam articuladas em torno de práticas que exigiam competências relacionadas à leitura, escrita, comunicação e interação com pessoas. Havia um fio condutor na sua trajetória que o ligava a esse período da sua vida. Nícolas reconhecia e destacava o valor que esse outro teve no seu processo de vir-a-ser, de tornar-se quem era hoje.

Compreendemos que o Sr. Luiz Gonzaga, a partir de uma aparente sensibilidade e atenção na relação com as crianças que ajudava com a doação de caixinhas da sua loja, instigou os motivos de Nícolas, provocou aquilo que o lançou para frente, ou seja, a sua curiosidade por conhecer e viver experiências novas. Percebemos que essa foi mais uma oportunidade vivida que ele aproveitou, assim como as demais abordadas nos tópicos anteriores, ou seja, a profissão da docência, mesmo sem ter experiência na área, e a organização da sua sala de aula como um ambiente personalizado para a realização do seu trabalho.

Nessa perspectiva, ao adentrar um universo desconhecido para ele até então, pois nunca havia lido um livro, aproveitou a oportunidade, lançou-se, aventurou-se e identificou-se com esse algo novo ao ponto de dizer: "Naquele momento eu estava viciado!". A maneira simples como essa situação aconteceu na sua vida e o impacto que teve no seu processo de descobrir-se, fazia com que ele reconhecesse e valorizasse de maneira impactante a colaboração desse senhor na sua vida. Ele era o outro que causou impacto na sua vida e, da mesma forma, Nícolas se esforçava para ser esse outro que poderia também impactar a vida e o futuro dos jovens, tanto na escola como em outros espaços da sua convivência. Reconhecia que o papel do Sr. Luiz Gonzaga, como o outro em dado momento da sua vida, possibilitou um 
processo de autoconhecimento, de descobrir-se em relação àquilo que ele gostava, e até então não sabia, a leitura.

No percurso da sua vida, a partir dos inúmeros materiais que leu, aprendeu que havia uma teoria que explicava o processo de autoconhecer-se, a Teoria das Inteligências Múltiplas. Considerou que poderia criar uma introdução do conteúdo sobre o sistema nervoso, estabelecendo uma relação entre as características de cada uma das inteligências com as possibilidades de futuras profissões que os alunos escolheriam, tendo em vista ajudá-los nesse processo. Nessa perspectiva, como o outro importante na vida dos alunos, planejou suas aulas utilizando as informações dessa teoria de forma articulada com o conteúdo da sua proposta curricular, abrindo espaço para abordar reflexões sobre o processo de escolha da profissão.

A maneira como Nícolas subjetivava a relação com as pessoas, principalmente as mais jovens, evidenciava uma vitalidade e uma vontade de colaborar a partir de situações que tinha aprendido nas circunstâncias da sua própria vida. Parecia querer viver de tal forma na perspectiva de conseguir ver a potencialidade da juventude em relação a um futuro de realizações. Mostrava uma força pessoal em relação a perceber as necessidades, preocupações e angústias dos adolescentes, lançando-se e assumindo o papel do outro, do "mentor", que poderia impactar as escolhas e decisões que em breve fariam ao concluir o Ensino Médio e ingressar na universidade ou no mercado de trabalho. $O$ valor e a importância que dava às pessoas foi registrado também em alguns indutores do completamento de frases:

4. Lamento não agradar mais pessoas.

39. Fico feliz quando faço outros felizes.

58. Alunos são pérolas preciosas.

59. Sempre que posso ajudo quem necessita.

72. As pessoas são uma caixinha de surpresa.

Além disso, identificamos também nesse quesito o enfoque analisado anteriormente em relação à maneira como Nícolas mantinha-se 
atento às manifestações dos alunos, articulando-se para manter ou modificar suas estratégias tendo em vista alcançar os resultados esperados. Percebemos que ele se esforçava para agir e intervir na vida dos alunos como o outro potencializador do processo de via-a-ser, ao mesmo tempo em que percebia alguns retornos, confirmando que estava alcançando os seus objetivos. Tal situação o mobilizava na perspectiva de continuar e aprimorar ainda mais esse trabalho, em um processo recursivo de continuar envolvido emocionalmente com as intervenções que planejava para suas aulas a partir do retorno que percebia dos seus alunos. Sentir-se motivado e aprimorar o seu trabalho parecia ser um processo subjetivo que acontecia em um fluxo dinâmico e contínuo a partir do retorno que tinha em relação a como os alunos percebiam e avaliavam as suas ações.

Apresentamos como exemplo uma situação destacada por ele em uma das nossas conversas, quando relatou um fato em que percebia como suas aulas tinham impactado a vida de um de seus alunos:

"[...] eu estava dando aula, é... no final do ano passado, finalzinho do ano passado estava dando aula, uma aula, quando escutei batendo na porta. No auge de uma aula, e eu não gosto de ser interrompido durante uma aula, eu sou meio nojento na sala de aula. Mas a insistência foi tão grande que eu resolvi interromper. Era um garoto. Eu quase não reconheci na hora que eu atendi. Ele foi meu aluno há três anos atrás, havia terminado o Ensino Médio. Aí ele chegou pra mim e disse:'Professor, quero te pedir desculpa por interromper. Eu sei que você não gosta, mas eu não tenho tempo mais. Eu estou com uma passagem para Minas Gerais ta, porque eu consegui um emprego lá e eu vim aqui antes de ir embora. Eu comecei a pensar: o que eu preciso fazer pra fechar todas as coisas aqui no Tocantins? E aí eu me lembrei de você hoje de manhã! Eu queria ir embora e eu queria ir naquela sala! Eu queria agradecer o professor Nícolas, porque o professor Nícolas me deu apoio e força!' Pra mim aquilo ali foi... foi chocante! Foi bonito pra mim! Foi assim o momento que eu acho que assim... é... isso acho que, é isso que compensa a vida da gente! $E$ eu fiquei emocionado! Eu acho que é o tipo de coisa que é mais do que aumento de salário, é mais do que qualquer outra coisa! Então esse tipo de coisa pra mim, eu acho que vale tudo! Faz você entender que tudo que você está fazendo aqui valeu a pena! Mas é..., só um negativo vai dizer: 'Poxa, você mudou a vida de uma pessoa!' E você acha que não é importante? Que tipo de professor eu seria se eu 
achasse que, porque eu participei da mudança da vida, não, eu não mudei, mas eu participei da mudança da vida dele, porque ninguém muda a vida de ninguém, você participa da mudança, né. E o garoto veio e me achou tão importante na vida dele, que não quis ir embora pra Minas Gerais antes de dizer o quanto você é importante pra mim! Valeu a pena! Se eu não atingi nenhum aluno naquele ano e atingi só ele, valeu a pena! Tudo o que eu fiz naquele ano e eu acredito que eu atingi mais do que ele, mas esse tipo de coisa que faz você acreditar na sua profissão e acreditar que você ta fazendo a coisa certa! Então continue fazendo! ${ }^{28}$

Essa fala evidencia o quanto ter o retorno sobre o trabalho realizado se constituía em um elemento importante na constituição subjetiva de Nícolas, principalmente o retorno dos alunos, que eram a razão maior de ser da sua atuação. $O$ relato que ele apresentou mostra o quanto esse momento foi importante para que ele continuasse se dedicando e empenhando na realização de intervenções que instigassem os seus alunos, ao invés de somente ensinar os conteúdos da sua disciplina.

No contexto dessa análise, identificamos na fala do aluno, relatada por Nícolas, alguns elementos da constituição subjetiva do professor, conforme discorremos no decorrer desse capítulo: "E aí eu me lembrei de você hoje de manhã!", mostrou que o professor era realmente importante para os seus alunos, que havia algo na relação estabelecida no cotidiano das aulas que o fazia alcançar os seus alunos para além do conteúdo trabalhado; "[...] eu queria ir naquela sala!", mostrou que esse lugar, a sala de aula, tinha algo especial, que ali aconteciam situações e vivências que eram lembradas com emoção pelos alunos, ou seja, o valor desse lugar para esse professor era sentido e vivido também pelos alunos, havia uma reciprocidade e um envolvimento no espaço-tempo dessas aulas; e "Eu queria agradecer o professor Nícolas, porque o professor Nícolas me deu apoio e força!", essa fala evidenciou o valor e a importância do trabalho realizado na perspectiva de alcançar o seu aluno naquilo que ele realmente precisava, em um momento em que estava vivendo um período de tomar decisões em relação ao seu futuro e encontrava um professor atento e sensível, que dispunha o tempo das suas

\footnotetext{
${ }^{28}$ Dinâmica conversacional com o professor - 28.09.15.
} 
aulas e a maneira de abordar os conteúdos na perspectiva de dar-Ihes apoio e força.

Percebemos que a maneira como aconteceu esse momento com o aluno, fez com que Nícolas vivesse e reafirmasse o seu sentimento de realização profissional em relação à maneira como atuava na docência. Suas colocações parecem reafirmar a convicção que tinha de que essa profissão tem um valor realmente importante quando acontece na perspectiva de instigar 0 aluno, de valorizar suas necessidades, ansiedades, expectativas e emoções. Entendemos que esse relato era revelador do quanto o retorno em relação as suas intervenções se configurava como um elemento da sua constituição subjetiva, pois era vivido como um processo dinâmico de retroalimentação da motivação que o impulsionava a continuar acreditando e realizando o seu trabalho.

Todavia, a opção por atuar profissionalmente nessa perspectiva não era simples, mas exigia dedicação e empenho. Conforme colocou em alguns momentos nas dinâmicas conversacionais, planejar dessa maneira era trabalhoso e cansativo, porém tinha clareza do foco que queria alcançar, o seu aluno, e, em função dele, sentia-se recompensado pelo esforço despendido. Entretanto, sentia-se frustrado com o pouco envolvimento com que vários colegas realizavam as suas aulas, principalmente com as atitudes daqueles que trabalhavam somente pelo salário. Sobre isso expressou:

"É muito frustrante pra mim saber que eu estou trabalhando, e às vezes na minha equipe tem muita gente que não está aqui por paixão, não está fazendo o que gosta $e$, consequentemente, não está fazendo bem feito. Você quer ver uma frase que me adoece, dita por um colega de trabalho: 'Estou aqui ganhando o meu dinheiro'. Eu também estou aqui..., não estou fazendo caridade! Eu sou um profissional da educação! Claro que eu também estou ganhando o meu dinheiro, mas estou ganhando meu dinheiro da forma mais digna possível! Se eu ganho meu dinheiro pra ensinar, eu vou tentar fazer isso da melhor maneira que eu puder, porque eu tento fazer o melhor!"29

29 Dinâmica conversacional sobre os registros no Diário "O cotidiano de um professor" $\left(1^{\circ}\right.$ encontro) -25.11 .15 . 
Essas abordagens foram evidenciadas também no registro de alguns indutores do completamento de frases:

7. Na escola as coisas não funcionam.

19. Fico inconformado com quem nem tenta.

31. Esforço-me sempre.

33. Frustra-me ver a incompetência alheia.

42. Sinto pena de quem nem tenta.

68. Meus colegas me decepcionam muito.

73. Eu sinto não poder fazer mais.

74. Me dá trabalho fazer bem feito.

A maneira como Nícolas se expressou mostra a emocionalidade com que vivia a sua profissão. A colocação do seu sentimento de frustração em relação a ver colegas que não trabalhavam como professores por gostarem da profissão, assim como ele gostava, mostrou como estava subjetivamente imbricado nesse processo. Além disso, ao referir-se ao grupo como "minha equipe", evidenciou o quanto se sentia parte do grupo, como integrante de um todo que queria que funcionasse, que tivesse um envolvimento mais intenso com os alunos e com a educação.

Conforme colocamos anteriormente, no início da análise, a relação de Nícolas com os colegas era permeada por conflitos, pois sua maneira de viver a docência incomodava vários professores. Além das questões materiais e concretas em relação à sala de aula, seus posicionamentos em relação à profissão também geravam desconforto e divergência de ideias. Frente a isso, se sentia frustrado e incomodado ante a circunstância dos colegas que viviam a docência a partir de outros motivos, diferentes do motivo principal que o movia em prol do tipo de trabalho que realizava, os alunos. Era com os alunos e para eles que movimentava-se e articula-se de maneira autônoma na perspectiva de promover o seu 
desenvolvimento. Era para eles e com eles que buscava fazer o seu melhor enquanto professor.

Com isso, inferimos que a configuração subjetiva de Nícolas impulsionava nele uma força pessoal de movimentar-se na perspectiva de encontrar possibilidades frente aos objetivos que buscava alcançar com o seu trabalho, apesar da frustração, do desânimo e da indignação que sentia, em algumas ocasiões, em relação a vários colegas. Nessa perspectiva seguimos a construção interpretativa dessa análise com mais um tópico, no qual apresentamos outros elementos constitutivos da sua subjetividade que impulsionavam nele atitudes autônomas no complexo contexto das relações sociais do cotidiano escolar.

\subsubsection{Nícolas: o novo e as mudanças}

- "Tudo de novo? Eu não! Cara, que tudo de novo? Tudo novo! [...] As caras são novas, os alunos são novos! Você tem que ser novo!"

A construção interpretativa que sistematizamos sobre Nícolas até esse momento, mostra elementos da sua configuração subjetiva que potencializavam e possibilitavam posicionamentos e intervenções propositivos, de busca de alternativas perante os desafios do cotidiano. Como parte integrante dessa análise, apresentamos nesse tópico enfoques relacionados à maneira como ele se posicionava, tanto em relação à busca pela concretização de objetivos pessoais e profissionais que assumia, quanto a circunstâncias vividas no seu cotidiano.

Percebemos que, no momento atual da vida de Nícolas, havia clareza em relação aos objetivos que buscava alcançar e, para isso, se fosse necessário empreender mudanças ou articular ações e intervenções, ele 
estava disposto e mobilizava-se nessa perspectiva. Quando os motivos que o impulsionavam eram realmente importantes para ele, parecia haver uma força pessoal de mobilização em prol de sentir-se realizado na perspectiva de alcançar os resultados para os quais se propunha.

Essa situação, por exemplo, foi nitidamente percebida no curso da pesquisa em relação ao fato que Nícolas destacou sobre a importância que o Sr. Luiz Gonzaga teve na sua vida, conforme analisamos no tópico anterior ${ }^{30}$. Recordar e reviver as emoções daquele período da sua vida, segundo o trecho da entrevista que apresentamos anteriormente ${ }^{31}$, parece ter sido um momento marcante para Nícolas no seu processo de participação na pesquisa. Na ocasião em que tivemos aquela conversa, ele disse que tinha perdido o contato com o Sr. Luiz Gonzaga, falando com tom de saudosismo, como se ainda gostaria de reencontrá-lo algum dia. A emocionalidade vivida naquele momento da pesquisa foi algo tão intenso e importante para ele, a tal ponto que se mobilizou e articulou na perspectiva de viver efetivamente esse reencontro. Após o seu período de férias, tivemos outro momento de conversa, no qual dialogamos sobre os registros que ele havia feito na sua Linha do Tempo. Quando falou sobre a sua infância e a participação do Sr. Luiz Gonzaga na sua vida, relatou, emocionado, o seguinte:

Professor: [...] mais ou menos aos 13 anos, não tenho certeza, eu acho que aproximadamente por aí foi quando eu encontro com esse que coloquei, mentor, Luiz Gonzaga, que por sinal eu tive o privilégio de me encontrar com ele agora em São Paulo, o procurei e consegui encontrá-lo! Olha, eu consegui até tirar uma foto com ele pra fazer uma postagem [Fez uma postagem no Facebook sobre o reencontro.] e fazia 20 anos que eu não o via! Então pra mim foi importante porque ia fazer o quê? Vinte anos que eu não o via! Então eu entro em contato com esse..., eu não sou amigo, porque pra mim ele não é um amigo, ele é um mentor, é muito mais do que um amigo, ta. E nós já conversamos sobre ele. [Fez referência à conversa da qual extraímos o trecho apresentado anteriormente sobre o fato em questão.] Ele praticamente me indicou primeiro livro e me orientou na vida acadêmica, na vida

\footnotetext{
${ }^{30}$ Nessa parte nos referimos ao tópico "Nícolas: as pessoas e seus motivos".

${ }^{31}$ Ver na página 134 o trecho da dinâmica conversacional sobre os registros no Diário "O cotidiano de um professor" ( $1^{\circ}$ encontro) - 25.11.15.
} 
literária. Então pra mim ele teve importância assim sem igual!

Pesquisadora: E ele sabe disso, Nícolas?

Professor: Se ele sabe?!! Um dos motivos de eu ir lá agora foi pra levar o meu livro, que ele não conhecia, porque eu perdi o contato com ele. Foi exatamente levar o meu livro pra ele, dizer isso pra ele agora com todas as letras, depois de tanto tempo, né! Aí ele ficou bem emocionado![...]

Pesquisadora: Que bacana! Que legal!

Professor: Eu me senti um menino de novo perto dele! Ele me indicou um..., alguns autores, alguns livros! Ele não mudou, continuou o mesmo!

Pesquisadora: Que bacana! Importante para ele saber isso também, não é!

Professor: São 20 e poucos anos!... Então eu fiz questão de voltar e procurá-lo! Foi um pouco complicado de achar, por ter perdido esses contatos com ele, a esposa dele já havia falecido, então uma sequência de fatos. Eu... e eu consegui! Foi uma das coisas importantes que eu fiz na vida agora nesse final de ano, que eu precisava fazer! Então ele entrou na minha vida exatamente aqui, e eu posso dizer que isso é um marco, porque os livros entram na minha vida exatamente aqui! [Mostrou na Linha do Tempo o ponto ao qual se referia.] ${ }^{32}$

Consideramos esse fato como uma situação de significativo destaque para a pesquisa na perspectiva da compreensão da constituição subjetiva de Nícolas. A maneira como ele mobilizou contatos e organizou seu período de férias, a fim de reencontrar o seu mentor, revelou como ele assumia atitudes propositivas para alcançar os objetivos aos quais se propunha. Essa mobilização envolveu contatos, o levantamento de informações e a organização pessoal e familiar, demonstrando uma produção subjetiva de articulação e satisfação na perspectiva de conseguir realizar metas pessoais. Entendemos que essa meta tinha uma significativa relevância nesse momento da sua vida, pois, ao colocar que "Foi uma das coisas mais importantes que fiz na vida agora nesse final de ano, que eu precisava fazer!", expressou o valor e a força que a articulação em torno desse reencontro tinha para ele, momento em que queria que esse senhor soubesse o quanto havia contribuído na sua trajetória.

\footnotetext{
${ }^{32}$ Dinâmica conversacional sobre os registros na Linha do Tempo - 19.01.16.
} 
Nesse reencontro, um dos materiais que sentia que precisava mostrar para o Sr. Luiz Gonzaga era o livro que havia escrito e publicado, no qual registrava suas reflexões e sua compreensão sobre o sentido e o valor da vida para o ser humano. No decorrer da pesquisa também fomos presenteadas com o livro, possibilitando entender melhor sua compreensão sobre tais assuntos. Era um livro de espessura pequena, que ele próprio financiou a publicação, com o auxílio de algumas pessoas, e significava o valor de uma meta alcançada já há alguns anos. Relatou, nas nossas conversas, que esse livro reunia textos que ele havia escrito para algumas aulas de Filosofia, no período em que ingressou na docência. Sua esposa e alguns amigos, ao lerem seus textos, o incentivaram a divulgar o material, pois consideravam que as reflexões poderiam contribuir para que as pessoas pensassem sobre a sua existência.

Assim, consideramos que o desafio colocado pela esposa e pelos amigos em relação à proposta de publicar seus textos, provocou em Nícolas uma produção subjetiva sobre a importância que o outro tem na vida das pessoas, um dos enfoques que analisamos no tópico anterior. Entendemos que, para Nícolas, escrever um livro poderia ser mais uma oportunidade para alcançar e tocar as emoções de pessoas que precisavam ser provocadas a pensar, refletir e tomar decisões no curso da sua vida, sendo que tal situação aconteceu efetivamente. Ele relatou sobre o retorno que teve de pessoas que leram seu livro, colocando para ele sobre a oportunidade que tiveram de refletir sobre assuntos que não era comum pararem para pensar sobre si mesmos em relação a tais perspectivas. Esses retornos confirmaram para ele que havia alcançado a meta que se propôs quando aceitou o desafio de publicar seus textos em um livro.

Frente a isso, entendemos que havia uma motivação pessoal intensa de Nícolas em relação ao reencontro com o Sr. Luiz Gonzaga, pois almejava presenteá-lo com o seu livro. A publicação era o resultado de uma meta alcançada também em virtude da contribuição dele na sua vida, pois era o mentor que o havia inserido no universo literário. Assim, interpretamos que os fatos relatados por Nícolas no trecho da conversa, apresentado acima, expressam os processos subjetivos vividos por ele em torno de articular-se e 
movimentar-se para realizar seus objetivos: o desafio de publicar o livro, já há algum tempo, e o reencontro com o seu mentor. Tais questões evidenciaram a força da sua constituição subjetiva, pois ambos objetivos implicaram complexas mobilizações para que se materializassem efetivamente. Sentir-se realizado por alcançar metas era algo que constituía a subjetividade de Nícolas, que o motivava a seguir realizando ações que considerava relevantes nos diferentes momentos da sua vida.

Além dessas questões, destacamos outro enfoque em relação ao movimento de Nícolas na perspectiva de reencontrar o Sr. Luiz Gonzaga. Sobre isso levantamos a hipótese interpretativa de que a sua participação na pesquisa pode ter se constituído em um fator motivacional, uma vivência que instigou e impulsionou nele algo que talvez já sentisse vontade de realizar a algum tempo, mas the faltava viver uma situação que o provocasse emocionalmente na perspectiva de gerar as ações necessárias para a concretização de tal fato. Nesse contexto, entendemos que as recordações vividas por ocasião da sua participação na pesquisa, principalmente nos momentos dialógicos, alcançaram uma dimensão simbólico-emocional forte, gerando sentidos subjetivos que o impulsionaram à tomada de decisões sobre o planejamento das suas férias.

Frente ao exposto, entendemos que a autodeterminação se apresentava como um elemento que o constituía subjetivamente, pois assumia posturas ativas no seu cotidiano, que o colocavam na posição de sujeito nos processos vividos. Essa situação acontecia tanto na sua vida pessoal quanto na profissional, aspecto que evidenciou a força desse elemento como constituinte da sua subjetividade. As decisões que tomava e assumia em relação a circunstâncias que considerava relevantes, evidenciavam seu protagonismo em torno de situações e mudanças que considerava relevantes na trajetória da sua vida. Tais questões evidenciam o posicionamento de González Rey (2009b) ao argumentar que 
[...] toda experiencia vivida se torna subjetiva dentro de la red de sentidos subjetivos que caracteriza la inserción social del sujeto en una multiplicidad de espacios sociales cuyas consecuencias sobre la subjetividad aparecen de forma integral dentro de las configuraciones subjetivas que se organizan en toda expresión humana. (p.15)

Nessa perspectiva, outra situação em relação à autodeterminação de Nícolas, acompanhada e vivenciada no percurso de realização da pesquisa, foi a sua decisão pela não adesão ao movimento de greve que aconteceu de 5 de Junho a 31 de Agosto. Considerando que a maioria dos seus colegas aderiu ao movimento, seus posicionamentos firmes frente aos conflitos vivenciados, evidenciaram sua força pessoal no enfrentamento de situações complexas. Ele estava convicto em relação à fragilidade dos motivos que mobilizaram o movimento e considerava que as reivindicações apontadas pelo sindicato e pelos colegas poderiam ser resolvidas de outras maneiras, argumento no qual sustentava sua decisão. Assim como ele, mais alguns professores não aderiram ao movimento, porém os conflitos pareciam ser mais intensos com Nícolas em virtude de colocar e defender seus posicionamentos sem se preocupar com as represálias que poderiam acontecer. Durante o período da greve em um momento de conversa que realizamos com três professores que não aderiram à paralisação, Nícolas apresentou a seguinte argumentação sobre a sua decisão:

"Eu acho que o momento é errado! A reivindicação é certa, é justa, é correta, mas o momento é errado. Esse é o argumento mais forte pra mim no momento, não é o único, mas o mais forte. O momento é absurdamente errado, porque deflagrar greve num momento como esse, à luz da experiência que o município teve ano passado, [Referia-se à greve que os professores da rede municipal deflagraram um mês antes das férias.] é você já..., é um movimento que, na minha opinião, já nasceu morto. Ele já nasceu morto! Ano passado ele nasceu vivo e morreu ao longo de 30 dias. [Nessa fala referia-se à greve que realizaram e na qual ele também participou.] $E$ esse ano que ele nasce morto, o que acontecerá com ele em agosto? Veremos o que acontece com ele em agosto! $\boldsymbol{E}$ aí, 
participar de um movimento, entrar em um movimento que já nasceu morto, pra mim me parece muito estúpido! Só porque todo mundo está indo naquela direção? Eu não vejo coerência! Caminhar pro buraco só porque todo mundo está caminhando pro buraco, entendeu? Eu sou inteligente $o$ bastante pra ver todo mundo caminhando pro buraco ou pro lado contrário e eu parar onde eu estou. Optei por ficar parado onde eu estou!"33

Os argumentos de Nícolas revelaram a firmeza dos seus posicionamentos, com colocações que chegavam inclusive a ser agressivas e fortes em relação à decisão daqueles que aderiram a greve. Frente a falas e argumentos desse tipo, os conflitos eram inevitáveis no contexto das relações entre o grupo. Os desentendimentos gerados pelas tensões dos diferentes posicionamentos provocaram situações desagradáveis de agressões verbais e, inclusive, publicações nas redes sociais. Outro professor que participou da conversa nesse momento da pesquisa relatou o seguinte:

"[...] pela pressão que eu sofri, pelo tipo de pressão, não pela pressão, mas pelo tipo, eu poderia processar alguns professores da casa aqui! Mas eu não vou fazer isso, mas eu poderia! Porque eu fui constrangido legalmente, é o termo da lei, constrangido legalmente, mas... Mediante testemunhas, por escrito na internet, eu poderia fazer um print daquilo, e eu poderia processar! Mas eu não vou fazer isso, porque eu entendo que algumas pessoas não tenham o conhecimento $e$ que o momento é de emoção mesmo ${ }^{\beta 4}$

O relato desse professor mostrou que as relações sociais entre 0 grupo estavam afetadas e fragilizadas pelos diferentes posicionamentos de adesão ao movimento, sendo que, apesar dessas circunstâncias, as decisões se mantinham firmes. Em outro momento dessa conversa, Nícolas colocou o

\footnotetext{
${ }^{33}$ Dinâmica conversacional com o grupo de professores que não participou do movimento da greve-29.06.15.

${ }^{34}$ Dinâmica conversacional com o grupo de professores que não participou do movimento da greve-29.06.15.
} 
seguinte: "Eu não me meto a fazer algo que eu não acredito!", destacando que, para ele, não havia dúvidas de que havia assumido a posição correta.

O fato de ser uma pessoa com posicionamentos firmes revelava sua segurança nas próprias decisões, assumindo os riscos das consequências que as mesmas poderiam acarretar. Ele sabia que a sua maneira de ser, agir e se posicionar incomodava alguns colegas. Entretanto, suas decisões não aconteciam aleatoriamente, mas se colocavam como parte de um processo pessoal de reflexão, levantamento de informações e análise. Parecia buscar sentir-se convencido e ter condições de argumentar e responder a questionamentos que os outros poderiam apresentar. Considerando que conhecia os demais professores da escola em virtude de trabalhar a vários anos nesse local, já sabia de antemão que seus posicionamentos poderiam gerar provocações e tensões. Assim, assumia uma postura ativa, e até mesmo defensiva, frente aos posicionamentos divergentes dos colegas do grupo.

Entendemos que a autodeterminação e a postura reflexiva e questionadora que assumia frente a situações em que precisava tomar decisões, possibilitavam a Nícolas empreender processos de mudança na sua vida, uma questão presente em vários momentos da sua trajetória pessoal e profissional. Ele parecia viver de maneira inquieta certas regularidades do cotidiano, como por exemplo, os problemas que eram vividos pelos colegas como algo natural e corriqueiro. Buscava resolver as questões que o incomodavam com a criação de possibilidades que estavam ao seu alcance realizar. Vimos isso, por exemplo, em situações relatadas e analisadas nos tópicos anteriores, em relação às metodologias das suas aulas e aos investimentos e melhorias que fez na sua sala de aula. Entretanto, tomar decisões que implicavam em processos de mudanças não era algo que fazia parte da vida de Nícolas somente no seu atual momento ou na fase adulta.

Nessa perspectiva, compreendemos que, constituir-se subjetivamente como um professor que toma decisões e realiza mudanças na sua ação pedagógica assumindo posturas autônomas e propositivas, assim como acompanhamos o cotidiano de Nícolas, não é algo que ocorre repentinamente na vida de uma pessoa. Ao invés disso, a constituição 
subjetiva acontece como um processo que se configura e reconfigura continuamente, de maneira dinâmica, complexa, contraditória e singular, nos percursos que cada pessoa vive no decorrer da sua trajetória (GONZÁLEZ REY, 2004a, 2005b, 2011a). Frente a isso, destacamos a seguir algumas situações apresentadas por Nícolas que consideramos relevantes no seu processo de constituir-se subjetivamente como o professor que conhecemos no período da pesquisa, isto é, o momento atual da sua constituição subjetiva.

No decorrer da pesquisa ele relatou várias decisões que tomou no curso da sua vida, as quais implicaram em processos de mudanças e reorganização pessoal. Desde a adolescência ele mobilizava-se na perspectiva de alcançar e realizar objetivos que considerava como possibilidades de melhorias frente à maneira como se organizava a sua vida em dado momento. Assim, relatou que, aos 17 anos, decidiu que queria mudar-se da cidade do interior de São Paulo, onde residia com a mãe e alguns irmãos. Ele já tinha alguns irmãos morando na capital de São Paulo e almejava buscar melhores oportunidades no mercado de trabalho, pois no local onde vivia suas perspectivas eram limitadas. Articulou-se e empreendeu essa mudança, conseguindo alcançar seu objetivo logo que chegou à capital, pois, em pouco tempo, conseguiu trabalho em um pequeno mercado. Entretanto, a conquista que alcançou com certa facilidade foi interrompida de maneira impactante devido à ocorrência de um acontecimento totalmente inesperado.

Ao falar sobre esse momento da sua vida, Nícolas destacou a difícil situação que viveu ao sofrer um grave acidente de trabalho logo nos primeiros meses em que mudou de cidade. Teve queimaduras gravíssimas no corpo e no rosto, ficando hospitalizado durante quatro meses. Fez em torno de dez cirurgias plásticas para reconstituir o rosto, principalmente uma das orelhas, na qual teve sérias complicações. Conforme relatou, sua situação estava sendo acompanhada por uma equipe médica que usava seu caso para um estudo sobre reconstituição de material cartilaginoso danificado. Apesar disso, frente ao desgaste dos processos vividos, em dado momento Nícolas tomou uma decisão firme. Cansado em relação às constantes internações hospitalares para a realização de procedimentos cirúrgicos, e ciente de que essa rotina ainda o acompanharia por um longo período da sua vida, decidiu 
interromper esse processo e assumir que as cicatrizes fariam parte da sua aparência física. Sobre isso, relatou o seguinte:

"Eu comecei uma jornada de cirurgias plásticas, minha vida era fazer cirurgias plásticas. Sair, fazer uma cirurgia. Voltava a trabalhar, passava de novo, fazer outra cirurgia. Mas chegou o momento que eu pensei, faltavam quantas cirurgias? Faltava uma quantidade infinita! Porque o processo de restauração era muito lento, porque eles precisam ir fazendo... Hoje eu não sei se é assim, mas estamos falando de, sei lá quantos anos atrás. Mas naquela época era muito lento, então tinha que fazer o trabalho, esperar o corpo responder, fazer o trabalho, esperar o corpo responder, entendeu?! Aí eu percebi que a minha vida nos próximos 10 anos seria..., seria escravo de cirurgias! $E$ aí eu parei! Eu simplesmente parei de fazer! Então isso é um trabalho, pára pela metade. Eu acho que nem na metade chegou. Eu nunca tive, eu não quero, as pessoas perguntam se eu tive problema, se senti vontade de voltar a fazer, eu digo: 'Eu não!'. Eu me sinto bem com isso! Isso é o que eu sou, acabou e pronto. Eu nunca me senti traumatizado por conta disso. Pelo contrário, eu me sinto é grato por eu ter sobrevivido, porque foi um acidente muito grave! Porque quem vê assim, eu me queimei apenas aqui e aqui, [Mostrou cicatrizes no rosto e na orelha.] mas na verdade eu me queimei todo, daqui pra cima eu me queimei todo. [Mostrou da cintura até a cabeça.] Considerando que eu não tenho nenhuma marca aqui, nem aqui, nem aqui, eu tenho muita pouca marca! Considerando o risco que eu sofri, e eu fiquei internado quatro meses! Não tenho trauma, eu tenho gratidão! Porque quando a gente sobrevive a um acidente, a gente tem que ficar grato por que sobreviveu a ele.

As colocações de Nícolas expressaram a força que teve no enfrentamento de uma situação tão complexa, vivida aos 17 anos, em um momento em que havia recentemente mudado do interior de São Paulo para a Capital e estava no início da sua vida profissional. A situação vivida configurouse como um processo impactante, gerando nele processos intensos de produção de sentidos subjetivos, em um momento em que seus projetos de vida foram interrompidos e precisou reorganizar-se.

\footnotetext{
${ }^{35}$ Dinâmica conversacional sobre os registros na Linha do Tempo - 19.01.16.
} 
Contudo, apesar do impacto vivido, Nícolas elaborava uma compreensão positiva ante os fatos e se sentia agradecido por ter sobrevivido ao acidente. Não se sentia vitimizado, fragilizado ou enfraquecido ante 0 ocorrido. Ao invés disso, assumia uma postura ativa ante a situação, a qual subjetivava como um momento de gratidão e desenvolvimento pessoal. Havia uma atitude de aceitação e fortalecimento pessoal, mesmo com as marcas físicas do passado. Apesar dos médicos insistirem para que mudasse sua decisão, colocou: "Eu falei com a equipe médica, eu não aguento mais fazer isso! Pra mim será mais traumático continuar com o processo de restauração do que viver do jeito que eu estou, é menos traumático viver do jeito que estou! Eu nunca me arrependi de ter feito isso!"36 Sua decisão em relação a abandonar as cirurgias e assumir que carregaria cicatrizes no seu corpo para o resto da sua vida, se apresentava como uma produção subjetiva de autodeterminação, de segurança em si mesmo e de força pessoal ao viver situações desafiadoras e inesperadas.

Ao conhecermos esse fato da vida de Nícolas e a maneira como ele viveu e superou o impacto das circunstâncias que precisou enfrentar, como por exemplo, o tempo de hospitalização, a retomada da vida social com tantos ferimentos e cicatrizes, as rotinas das cirurgias plásticas e a decisão pela interrupção do tratamento de recuperação estética do seu corpo, levantamos questionamentos em relação ao processo de subjetivação desse momento da sua vida, para os quais ainda não tínhamos respostas. A questão principal para a qual buscávamos uma compreensão mais aprofundada era em relação à gênese desses processos. Como ele havia se constituído subjetivamente dessa maneira para conseguir enfrentar uma situação tão complexa? O que havia acontecido na sua história de vida que possibilitava a força pessoal e a autodeterminação que teve para superar os impactos vividos e retomar a sua vida, sem se sentir fracassado ou vitimizado pelas circunstâncias e dificuldades enfrentadas?

Assim, na perspectiva de levantar informações para 0 aprofundamento da construção interpretativa sobre a constituição subjetiva de

\footnotetext{
${ }^{36}$ Dinâmica conversacional durante o processo construtivo-interpretativo das informações da pesquisa - 16.05.16.
} 
Nícolas, voltamos ao campo de pesquisa e realizamos outro momento de diálogo, envolvendo-o como participante no processo de análise dos indicadores ${ }^{37}$, conforme explicamos no capítulo metodológico ${ }^{38}$. Esse momento se configurou como um procedimento metodológico de muito valor para a construção das informações. Retomamos nessa reflexão sobre a importância dos princípios epistemológicos que sustentaram o percurso da nossa pesquisa, pois, conforme a Epistemologia Qualitativa,

Pesquisador e participante estão numa permanente tensão reflexiva recíproca no curso desse tipo de pesquisa, o que torna o participante produtor de um pensamento que o implica no diálogo com outros participantes e com o pesquisador, posição ativa essencial para o compromisso subjetivo de suas produções no curso desse processo. [...] As ideias e o desenvolvimento de modelos teóricos no curso da pesquisa transforma a pesquisa num processo criativo em que a produção intelectual como produção subjetiva imaginária passa a ser um recurso essencial da própria pesquisa. (GONZÁLEZ REY, 2014b, p. 57-8)

Assim, enquanto sujeitos do processo da pesquisa que realizávamos, nessa conversa, Nícolas colocou informações importantes em relação ao processo de constituição da sua postura frente a várias situações vividas. Em relação ao fato que estamos analisando, os impactos do acidente, apresentamos um trecho desse diálogo:

Pesquisadora: E aí, esse tempo que você ficou no hospital, quem the acompanhou?

Nícolas: Meus irmãos, minha mãe, que estava no interior, mas veio nessa época. Ela ficou em São Paulo nesse período.

Pesquisadora: Você tinha dezessete anos nessa época, essa era a idade que estava começando a vida. Como foi se recompor desse impacto? Pois você deveria ter sonhos e projetos de vida e aí, de repente, foram interrompidos.

\footnotetext{
${ }^{37}$ Dinâmica conversacional durante o processo construtivo-interpretativo das informações da pesquisa - 16.05.16.

${ }^{38}$ Ver Capítulo III - Base epistemológica e metodológica.
} 
Nícolas: É, mas eu sempre pensei, eu não mudei isso, penso assim até hoje! Eu sempre pensei que na vida, eu não penso muito no que eu perdi, eu sempre penso no que eu ganhei. Eu ganhei a oportunidade de estar vivo, eu poderia estar morto! Então eu sempre pensei nessa situação no aspecto positivo e nunca no aspecto negativo. Bem, teve perdas, teve marcas. A vida é feita de marcas! Quando a gente deixar essa vida, o que a gente leva dela são as marcas. Traumas não. Eu não funciono bem nessa dinâmica de traumas, eu não me sinto traumatizado! Foi uma experiência de vida!

Pesquisadora: E no momento que aconteceu, como foi esse processo de conseguir sentir isso? Quando viveu isso, com 17 anos, você pensava assim como pensa hoje?

Nícolas: Em relação a isso eu sempre pensei assim, sempre encarei a vida nessa perspectiva: o que eu estou ganhando e não no que eu estou perdendo. Isso faz parte do que eu sou! Acho que aprendi isso com a minha mãe. A minha mãe sempre vivia muito assim, ela sempre via o que ela ganhou e não o que ela perdeu. A minha mãe não olha muito para as perdas da vida, ela olha pros lucros da vida. Tanto é que eu gosto muito da vida, eu gosto muito da minha mãe! Tanto que uma vez uma pessoa fez um comentário, e minha mãe estava perto, a pessoa disse: "Ah, na nossa época que era bom!". A minha mãe disse: "A vida hoje, minha filha, a vida hoje tudo é com facilidade". A minha mãe está velha, está doente, sabe que a vida dela está chegando ao fim, mas ela ainda consegue ver o que há de bom hoje e não o que houve de bom no passado. Passado é passado. Então eu acho isso legal na minha mãe! Então eu acho que eu recebi isso da minha mãe, de olhar sempre pro que há de bom. Ah, mas você ficou marcado, ficou traumatizado. Não, eu fiquei vivo! Isso foi importante! ${ }^{\beta 9}$

As colocações de Nícolas revelaram que, viver a vida com uma postura ativa e positiva frente aos desafios do cotidiano, era algo presente desde a sua infância. As informações da pesquisa possibilitam elaborar uma construção interpretativa de que a presença da postura de vida da sua mãe, sinalizando uma compreensão de possibilidades, ao invés de dificuldades, possibilitou em Nícolas um processo de constituição subjetiva na perspectiva de colocar-se como sujeito ativo e propositivo ante as circunstâncias vividas. A maneira como subjetivava as situações vividas, compreendendo que os ganhos eram sempre maiores do que as perdas, potencializava nele uma força pessoal

\footnotetext{
${ }^{39}$ Dinâmica conversacional durante o processo construtivo-interpretativo das informações da pesquisa - 16.05.16.
} 
de enfrentamento das situações, evidenciando o caráter gerador da sua subjetividade em relação ao processo de criar ações e intervenções para resolver problemas e/ou alcançar os objetivos que se propunha alcançar.

Assim, compreendemos que a presença da postura firme e positiva da mãe se constituiu como um fator gerador de possibilidades na constituição subjetiva de Nícolas também em virtude da maneira como viveu a infância e acompanhou as decisões que ela tomou ante os problemas que viveram. Em uma das nossas conversas, relatou com emoção e saudade as recordações da infância vivida nas fazendas em que seu pai trabalhava como administrador.

\begin{abstract}
"A minha vida na fazenda é igual os livros! Se você pegar os livros de José Lins do Rego, se você pegar o Vasconcelos, aqueles... aqueles autores que levam você pra aquela... para a literatura chamada de bucolismo, o homem em contato com a natureza e que é feliz de verdade! Eu vivi isso na minha infância, eu tive o privilégio de viver isso na minha infância! Foi uma infância pobre, foi uma infância difícil, como a maioria das infâncias, mas foi feliz, eu e muitos irmãos. Acho que ter muitos irmão foi muito bom, um ponto positivo, então. [...] Sete irmãos! Então nós éramos uma gangue em uma fazenda! Então fazíamos jangadas, brincávamos nos rios, tinha cachoeiras, tinha frutas, tinha cavalos, tinha boi, tinha tudo! Então eu me lembro dessa fase da infância, da escolinha da fazenda, que é muito interessante! Quando lembro disso, lembro com tanto carinho! A gente indo para escolinha da fazenda levando aquelas latas de Leite Ninho com farofa de ovo para comer na hora da merenda! Era muito dez, eu lembro disso com uma saudade... [...] Minha mãe criava os filhos, minha mãe era uma perfeita do lar! Minha mãe era perfeita do lar, meu pai era o administrador da fazenda e nós, os aventureiros das fazendas! $E$ eram sempre fazendas muito grandes, por que meu pai sempre foi muito bom para mexer com fazendas. Ele era daqueles que era cobiçado pelos fazendeiros. Era a paixão da vida dele, era não, é. $^{\sharp 40}$
\end{abstract}

Seu relato sobre a infância mostra que viveu intensamente a liberdade que a vida no contexto rural the proporcionou, falando de lembranças das brincadeiras e da convivência com os irmãos, sendo ele o irmão do meio,

\footnotetext{
${ }^{40}$ Dinâmica conversacional durante o processo construtivo-interpretativo das informações da pesquisa - 16.05.16.
} 
de um grupo de sete. Recordou saudosamente também a sua vida estudantil na escola da fazenda, a qual era multisseriada. Quando começou sua escolarização, entre 7 e 8 anos de idade, já estava alfabetizado, pois brincava de escola com os irmãos em casa e os mais velhos ensinaram os mais novos a ler e escrever. Em virtude disso, uma primeira grande conquista da sua vida foi ser promovido automaticamente para a segunda série, situação que destacou da seguinte maneira em uma das entrevistas: "Então isso pra mim foi muito interessante, porque eu já comecei a escola pulando um ano, saindo, pulando o primeiro ano e já indo pro segundo. Uma coisa que eu nunca esqueci!!"41. Essa situação pode ter se constituído em um processo subjetivo de fortalecimento da autoconfiança, algo que possivelmente já acontecia também nas aventuras que experimentava nas brincadeiras nas fazendas. Ao ingressar na escola, um momento novo na sua vida, encontrou uma professora que percebeu seu processo diferenciado de aprendizagem e o desafiou a viver uma situação ainda mais nova.

Além disso, a maneira como viveu essa situação, conseguindo corresponder à expectativa da professora de que teria condições de acompanhar a segunda série mesmo sendo seu primeiro ano na escola, pode ter contribuído para se constituir em Nícolas uma questão que analisamos anteriormente: o aproveitamento das oportunidades que percebia no curso da sua vida e que considerava como relevantes. Apesar de nessa situação a escolha não ter sido sua em relação a avançar para a segunda série ou permanecer na primeira, os resultados satisfatórios que alcançou podem ter fortalecido nele a produção subjetiva de que as oportunidades e os desafios não deveriam ser desperdiçados, pois poderiam ser possibilidades de viver algo que talvez não aconteceria novamente. Frente a isso, a autoconfiança e a vontade de aproveitar as oportunidades, articulavam-se ao processo de lançarse em relação ao novo, uma postura de Nícolas ante as circunstâncias da vida, que pode ter sua gênese constituída em situações como essas, vividas já na sua infância.

\footnotetext{
${ }^{41}$ Dinâmica conversacional durante o processo construtivo-interpretativo das informações da pesquisa - 16.05.16.
} 
Contudo, considerando que a vida real e concreta não se constitui como um processo linear e rotineiro, circunstâncias aconteceram na trajetória de Nícolas trazendo também desafios que foram difíceis e mudaram o seu cotidiano, provocando movimentos de reorganização no seu núcleo familiar. Uma situação de destaque nessa perspectiva aconteceu quando Nícolas tinha 11 anos de idade. Seus pais se separaram e ele e os irmãos seguiram a vida com a mãe, que se mudou com os filhos para a cidade. A maneira como Nícolas relatou a vivência dessa situação evidenciou que esse processo possivelmente foi vivido com o suporte da maneira positiva como sua mãe enfrentava as situações da vida:

"Nunca foi traumático para mim, por que o relacionamento entre meu pai e minha mãe sempre foi meio agressivo. Meu pai, homem muito bruto, homem de fazenda mesmo, homem de fazenda, entendeu. Então, meu pai era bruto e a gente sabia que não era um relacionamento bom. Então quando houve a separação do meu pai e da minha mãe, não houve um choque, pra mim foi normal. Continuei tendo um relacionamento com meu pai, mas morava com minha mãe, entendeu. Não considero isso um trauma. Considero uma experiência de um relacionamento mal sucedido.",42

Apesar de relatar com certa tranquilidade a situação ocorrida, em outro momento da pesquisa referiu-se a esse fato da seguinte maneira: "Então a nossa vida sofre uma mudança dramática aquil..."43. As alterações que aconteceram na vida familiar não foram simples, pois implicaram em uma mudança no lugar onde moravam, na escola e na rotina da vida da mãe, que começou a trabalhar em uma fábrica de beneficiamento de amendoins, que empregava somente mulheres. Entendemos que a maneira como Nícolas compreendia o esforço que a mãe teve para recomeçar a vida, também se configurou como um fator que gerou nele uma produção subjetiva de fortalecimento e de uma postura ativa ante os desafios. Construímos essa hipótese interpretativa a partir de informações importantes que Nícolas

\footnotetext{
${ }^{42}$ Dinâmica conversacional durante o processo construtivo-interpretativo das informações da pesquisa - 16.05.16.

${ }^{43}$ Dinâmica conversacional sobre os registros na Linha do Tempo - 19.01.16.
} 
apresentou sobre sua mãe na conversa que tivemos no momento de socialização dos indicadores, conforme apresentamos no trecho a seguir.

Pesquisadora: E, para ela, criar sete filhos também não deve ter sido fácil...

Nícolas: Sozinha, porque ela não teve ajuda. Não é como hoje que você entra na justiça e tem que pagar pensão. Naquela época ajudava se quisesse. E o meu pai sempre fez a opção de não querer. Ele fez parte do grupo que não queria, então... foi sozinha mesmo.

Pesquisadora: Então, Nícolas, quando vocês foram para a cidade a sua mãe trabalhava? Você falou que ela trabalhava em uma indústria, não é?

Nícolas: É, tinha uma indústria de, chamada de beneficiamento de amendoim. Então, ela sempre... Faz um processo manual, totalmente manual, e colocavam mulheres pra fazer esse processo de separação de amendoins. Amendoins bons, amendoins ruins, tipos de amendoins especiais e aí ensacavam pra distribuir. Ela trabalhou boa parte da vida dela fazendo isso. Praticamente criou os filhos nessa indústria de amendoins.

Pesquisadora: $E$ aí foi uma mudança muito grande na vida dela também, né?

Nícolas: Foi! Mas a minha mãe, ela não tem medo de desafios! Essa é uma característica da minha mãe até hoje. Minha mãe não tem medo de desafios, o que for preciso fazer, ela faz. Não reclama, ela faz!

Pesquisadora: E aí, você acha que isso, então, lhe ajudou?

Nícolas: Eu acho que sim! Eu acho que isso foi fundamental na minha vida! A filosofia da minha mãe sempre foi: não reclame, trabalhe! Pare de reclamar e vá trabalhar, porque se está ruim com você trabalhando, imagine se você parar de trabalhar, vai ficar pior, com certeza!

Pesquisadora: $E$ isso faz parte muito da maneira como você pensa hoje.

Professor Nícolas: Isso! Eu acho que faz parte da maneira como eu encaro a vida! Ela influenciou muito, de uma maneira bem positiva. Eu acho que isso é positivo! É positivo. Eu acho que ela influenciou muito nesse aspecto aí. ${ }^{44}$

Considerando as colocações de Nícolas e a interpretação que construímos sobre a sua subjetividade, compreendemos que a maneira como

${ }^{44}$ Dinâmica conversacional durante o processo construtivo-interpretativo das informações da pesquisa - 16.05.16. 
viveu sua infância e adolescência se configurou como um dos elementos importantes na gênese dos processos da sua constituição subjetiva. A convivência com sua mãe, uma pessoa forte, firme e propositiva, que assumiu os desafios da reorganização da vida familiar, sem o apoio do marido, alcançando êxito na educação dos filhos, constituiu-se em um processo de produção subjetiva de que era possível criar e encontrar alternativas frente aos desafios da vida, por mais complexos que eles fossem.

Além da presença da mãe como importante elemento no contexto dessa construção interpretativa, compreendemos que havia ainda outro, o qual também estava relacionado com a presença dela, e que integrava o processo de constituição da subjetividade de Nícolas. A sua mãe era uma pessoa religiosa que participava ativamente de uma igreja cristã e, desde cedo, havia inserido todos os filhos na prática de uma vida espiritual. Interpretamos que possivelmente essa tenha sido uma das forças que potencializou nela a segurança em relação às decisões que tomou frente às circunstâncias vividas, aspecto presenciado pelos filhos no contexto familiar. Quando conversamos com Nícolas sobre a sua vida religiosa, ele relatou o seguinte:

Pesquisadora: E a participação na religião, você teve desde pequeno?

Nícolas: A vida toda! Isso é muito da minha mãe também, muita influência da minha mãe, sempre. Minha mãe sempre foi e continua sendo. Para ela a coisa mais importante, quando a gente liga para ela, ela pergunta: "Você está indo na igreja?" Chega a ser engraçado!

Pesquisadora: Vocês frequentavam lá na fazenda, e depois, quando mudaram para a cidade?

Nícolas: Quando morávamos na fazenda nós íamos à igreja, mas quando mudamos para a cidade continuamos. A prática sempre fez parte da vida inteira. ${ }^{45}$

Parece-nos que as experiências da vida religiosa, a partir das orientações e do exemplo que tinha da própria mãe, a qual se configurava como um referencial para o seu viver, integravam seu processo de produção

${ }^{45}$ Dinâmica conversacional durante o processo construtivo-interpretativo das informações da pesquisa - 16.05.16. 
subjetiva em relação a sua compreensão sobre o sentido da vida. Retomando, por exemplo, a maneira como Nícolas subjetivou os impactos do acidente de trabalho, vivido aos 17 anos, entendemos que a vida espiritual também se constituía como um elemento da sua constituição subjetiva em relação à força pessoal que tinha no enfrentamento das situações vividas. Retomamos um trecho de sua fala, apresentado anteriormente, no qual identificamos essa compreensão: "Considerando o risco que eu sofri, e eu fiquei internado quatro meses! Não tenho trauma, eu tenho gratidão! Porque quando a gente sobrevive a um acidente, a gente tem que ficar grato por que sobreviveu a ele".

Entendemos que ele considerava, a partir dos seus princípios cristãos, que deveria sentir-se agradecido por ter sobrevivido a uma situação em que poderia ter morrido. A maneira como subjetivava a força que teve para sentir-se grato ao invés de traumatizado, parecia estar relacionada com a fé que tinha em Deus, uma presença que considerava marcante a partir da vida religiosa que teve desde a infância. Ao conversarmos sobre a força pessoal que ele demonstrava frente a situações complexas e à maneira como vivia os processos de mudanças, Nícolas expressou a compreensão que tinha sobre 0 sentido da vida e sobre Deus, no seu atual momento.

Pesquisadora: O que você acha que dá a você essa força para pensar desse jeito com relação à mudança?

Nícolas: Eu acho que acreditar em Deus é uma delas! Eu acho que acreditar em Deus é isso, eu acho que Deus é uma força. Eu acho que alguém perguntar: "O que é Deus pra você?" De vez em quando perguntam. É uma força positiva imensa. Eu acho que toda a equação resultante da força positiva de todo o Universo, a gente chama de Deus. Deus pra mim é uma força positiva, não consigo vê-lo de outra forma. Então, eu acredito que seja Deus! Claro que devem existir outras coisas, mas a primeira é Deus! Deve ter outras coisas que me levaram a isso como a minha própria formação, minha própria história de vida, entendeu. [...] Acredito que ainda tenho uma jornada pela frente e espero que seja uma boa jornada! Vou fazer todo o possível pra que seja uma boa jornada, até que chegue um momento que seja o fim, como vai chegar pra todo mundo. Tipo, o meu filho esse tempo todinho, esses dias ele perguntou se eu tenho medo de morrer, porque eu já estou ficando velho, 50 anos. "Você tem medo de morrer?" Eu falei: "Não!" Eu só tenho um medo na vida, pode parecer muito clichê, mas eu só tenho medo de não 
viver, e não de morrer. É tanto que eu já falei pra minha esposa que quando eu morrer pode colocar na minha sepultura: “Esse cara viveu a vida!". Nesses 50 anos, eu vivi 50 anos e não a metade desses 50. [...] É a minha percepção da vida, eu acho que a vida é isso. A vida é isso: efêmera, passageira. Como diz nos livros, a vida, as névoas! A gente lá do sul, sudeste, sabe o que é isso! Você acorda pela manhã com aquela névoa, neblina, que você não enxerga nada. Daqui a uma hora o sol abriu e não tem névoa alguma, foi tudo embora. A vida é como uma névoa! Hoje você está brilhando e amanhã nem está aqui mais. ${ }^{46}$

As colocações de Nícolas nos possibilitam interpretar que a sua compreensão sobre o sentido da vida estava alicerçada na espiritualidade da relação estabelecida com Deus, a qual foi construída desde as vivências que teve na infância. A força e a grandiosidade como se referia a esse Ser, pareciam gerar uma produção subjetiva de gratidão, fortalecimento e motivação para viver intensamente o seu cotidiano. Nessa perspectiva, entendemos que a maneira como subjetivava sua relação com Deus também se configurava como um elemento que estava na gênese dos processos da constituição subjetiva de Nícolas. A espiritualidade, a relação com os outros e consigo mesmo se mostravam como questões presentes e importantes nos diferentes momentos da sua vida. A importância e o valor da vida foi registrado também em alguns indutores do completamento de frases:

2. O tempo mais feliz da minha vida é hoje.

5. Meu maior medo é não viver a vida,

30. Amo o que sou e o que tenho.

53. Meu tempo é bem aproveitado.

67. Eu sou feliz.

71. Eu não quero viver em vão.

Assim, dando sequência à análise das decisões e mudanças que Nícolas tomou no curso da sua vida, entendemos que o fato de ter vivido um momento dramático, em que esteve entre a vida e a morte, parece ter instigado

\footnotetext{
${ }^{46}$ Dinâmica conversacional durante o processo construtivo-interpretativo das informações da pesquisa - 16.05.16.
} 
nele a vontade de viver e conhecer situações novas. Um acontecimento que poderia ter talvez gerado insegurança ou medo frente ao novo, parece ter impulsionado uma produção subjetiva em relação a aproveitar a vida e criar oportunidades. Nessa perspectiva, compreendemos que possivelmente esse possa ter sido o motivo maior da sua articulação em relação a empreender outra mudança de cidade na sua vida quando, aos 20 anos, decidiu morar no Rio de Janeiro. Sobre essa experiência relatou o seguinte:

"Eu fico mais ou menos até os 20 anos nessa vida bancária, eu largo tudo e faço uma aventura no Rio de Janeiro. Então me mudo pro Rio de Janeiro! Foi muito interessante, principalmente em nível de cultura. Apesar de São Paulo e Rio de Janeiro estarem tão pertinho, quando você sai de São Paulo e vai pro Rio de Janeiro é outra cultura, outra cabeça, é outra vida, é outra tudo! Então foi uma experiência pra mim também que foi inesquecível esse tempo que eu vivi no Rio de Janeiro!"47

"Foi uma experiência, foi quando eu saí do Bradesco. Eu fiquei desempregado, e tinha um amigo meu [...] que a família dele é do Rio de Janeiro. Aí eu tive essa experiência, queria conhecer o Rio de Janeiro! Adolescente, sem compromisso na vida, com algum dinheiro na mão! Vou pro Rio de Janeiro!"48

Apesar de colocar que esse momento da sua vida significou para ele um período de experiência e de aventura, entendemos que sua decisão pode estar relacionada a uma produção subjetiva em relação a aproveitar a vida, que compreendia como sendo efêmera como a névoa, conforme colocou. Além disso, tanto essa mudança de cidade, quanto a anterior, quando saiu do interior e foi para a capital, partiu de uma motivação e decisão sua, mostrando a postura ativa como foi construindo a própria trajetória, criando e buscando oportunidades que considerava importantes para os diferentes momentos do seu percurso.

\footnotetext{
${ }^{47}$ Dinâmica conversacional sobre os registros na Linha do Tempo - 19.01.16.

${ }^{48}$ Dinâmica conversacional durante o processo construtivo-interpretativo das informações da pesquisa - 16.05.16.
} 
Nessa perspectiva, aos 23 anos empreendeu mais um momento de mudança de vida quando decidiu mudar-se para o Paraná. O motivo que o levou a essa decisão era bem definido, ou seja, decidiu seguir carreira como pastor da Igreja Presbiteriana, a qual frequentava desde criança. Os líderes religiosos dessa denominação tinham uma formação acadêmica no curso de Teologia e, como decidiu seguir essa carreira, era necessário dedicar-se aos estudos, uma situação que the era agradável, pois gostava de ler e estudar. Durante esse período ingressou também em um curso de Filosofia, explicando que buscou essa formação por curiosidade e pela proximidade que há entre as duas áreas. Entretanto, o encontro entre as abordagens dos dois cursos de graduação o colocou ante uma situação de incômodo e inquietação. Havia uma incompatibilidade entre os dogmas religiosos e a flexibilidade e fluidez como ele compreendia o sentido da vida. Ao falar sobre o período em que estudou e exerceu a liderança religiosa como pastor comentou:

"Foi interessante! Assim como tudo na minha vida, foi interessante! Tudo é muito importante, entendeu. Mas não é uma coisa muito pra mim não, eu sou.... você conhece Rubens Alves? Acho que já falei para você de Rubens Alves. Eu me identifico muito com Rubens Alves. Ele não se encaixava em caixinha nenhuma não, não dava para colocá-lo dentro de uma caixinha, razão pela qual ele caiu fora. [Referia-se ao fato de que Rubem Alves também foi pastor presbiteriano durante um tempo da sua vida.] Eu acho que sou muito parecido com ele e continuo sendo, não consigo ficar em caixinha nenhuma ainda hoje. Sou alguém bastante religioso. Acredito em Deus, é essencial para o ser humano! Não consigo ver uma vida é... tentando colocar Deus de fora. Acho que não dá, pra minha concepção de vida não dá. Mas não consigo entrar em caixinha nenhuma. Até tento, continuo até hoje, de vez em quando vou para umas caixinhas aí, mas eu percebo que as caixinhas querem te limitar, te prender dentro delas, fechar, embalar e eu não consigo viver essa experiência de viver encaixotado. [...] Foi interessante, mas alienante, como toda experiência religiosa! Na minha opinião, ela é alienante, dogmática. Alienante é o pressuposto da religião. Religião é isso, não tem como ser diferente. Ela não foi projetada para ser diferente. Ela foi projetada para dizer que isso é assim e que não existe a possibilidade de ser de outro jeito, que você tem que viver assim e que não tem possibilidade de viver de outro jeito. E eu não acredito nisso! Não acredito que as coisas estejam limitadas assim. Acho que as coisas são muito mais amplas do que nós 
podemos imaginar. Me norteio pela frase de Shakespeare: 'Existem muito mais coisas entre o céu e a terra do que possa imaginar a nossa vã filosofia'. Não dá pra dizer o que é isso ou aquilo. Tudo bem, pode ser isso também, mas não é só isso, é mais que isso. Então eu não questiono a experiência religiosa de ninguém. Ótimo, essa foi a sua experiência religiosa. Observação: sua experiência religiosa! Não é a experiência religiosa de todo mundo, tá. Não vamos dizer que todo mundo tem que viver essa experiência sua, por que o indivíduo pode se dar o luxo de ter uma experiência diferente da sua." 49

No trecho que destacamos Nícolas mostrou a maneira firme com que defendia seus posicionamentos, argumentando de maneira crítica e convincente. Além disso, mostrou novamente a importância da espiritualidade e da relação com Deus na sua vida, evidenciando sua compreensão sobre a liberdade como um elemento imprescindível a esse processo. Contudo, o movimento de busca pela formação religiosa em uma igreja que conhecia desde a infância e sabia que era dogmática, parece evidenciar um elemento contraditório na sua constituição subjetiva.

Considerando que a mudança, a liberdade de expressão, a criação de situações diferentes e a busca por alternativas frente aos desafios se apresentavam como elementos constitutivos da sua subjetividade, seu projeto de vida de seguir a carreira religiosa parecia evidenciar uma decisão incoerente com a maneira como vinha construindo sua trajetória até aquele momento. Essa construção interpretativa nos remete aos argumentos de González Rey (2002, p. 37) quando coloca que "a subjetividade é um sistema processual, plurideterminado, contraditório, em constante desenvolvimento, sensível à qualidade de seus momentos atuais, o qual tem um papel essencial nas diferentes opções do sujeito".

Assim, interpretamos que o caráter conflituoso dos processos subjetivos vividos por Nícolas nos anos em que estudou e viveu a carreira religiosa, potencializaram nele a reflexão, o questionamento de posicionamentos divergentes e a capacidade argumentativa. Consideramos

\footnotetext{
${ }^{49}$ Dinâmica conversacional durante o processo construtivo-interpretativo das informações da pesquisa - 16.05.16.
} 
que tal situação pode ter ocorrido em virtude da oportunidade que ele buscou de cursar duas áreas que alcançam um nível aprofundado de compreensão teórica dos fatos que envolvem o ser humano, tanto na sua espiritualidade quanto na racionalidade. Provavelmente quanto mais estudava, mais se questionava sobre os assuntos que discordava.

Nessa perspectiva, o conflito foi um processo praticamente inevitável. Expressou-se sobre esse momento colocando o seguinte: "[...] entre o Nícolas e o Pastor Presbiteriano existe uma ruptura, um abismo! Claro que isso não poderia dar certo, como não deu mesmo e graças a Deus que não deu certo! Eu prefiro que não tenha dado!" ${ }^{\prime 50}$. Interpretamos que a ruptura, o abismo a que ele se referiu mostraram que os estudos da Teologia e da Filosofia o colocavam constantemente frente ao desafio de ter que posicionar-se sobre questões relacionadas à espiritualidade, à igreja e à vida.

Nesse processo, mesmo percebendo que havia divergências, concluiu seus estudos, retornou a São Paulo e começou a trabalhar como pastor, período em que conheceu a sua esposa. Contudo, a compreensão que ele tinha em relação ao caráter permanente e inquestionável dos dogmas religiosos, o encaminhou na perspectiva de buscar outras possibilidades para sua vida. Colocou que esse processo de mudança aconteceu de maneira tranquila na sua vida.

"[...] Foi tranquilo, muito tranquilo, por que aconteceu quando eu fui inserido na educação. Então foi uma coisa bem light, bem tranquilo. [...] Foi quando eu vim para o Tocantins. Foi quando eu descobri uma outra vocação minha! Continua sendo ensinar, por que lá era ensinar, só que ensinar de uma forma dogmática, e aqui é ensinar de uma forma mais aberta. Aliás, ao contrário, é exatamente ao contrário do dogmatismo a educação tem... a pessoa não pode ser dogmática! Tem professor que ele é dogmático, mas eu acho que a proposta do educador é de não ser dogmático. As coisas são assim, mas elas não precisam ser assim, podem ser diferentes. ${ }^{, 51}$

\footnotetext{
${ }^{50}$ Dinâmica conversacional sobre os registros na Linha do Tempo - 19.01.16.

${ }^{51}$ Dinâmica conversacional durante o processo construtivo-interpretativo das informações da pesquisa - 16.05.16.
} 
Apesar de demonstrar, conforme analisamos nos tópicos anteriores, que se preocupava e se esforçava para alcançar resultados satisfatórios em relação às metas que estabelecia, também não tinha problemas em relação a decidir pela mudança quando compreendia que ela era necessária. Assim, resolveu se casar com a sua esposa e seguiram a vida para o Tocantins, momento em que encerrou suas atividades como pastor e ingressou na carreira docente, conforme abordamos no início do capítulo.

A construção interpretativa que elaboramos sobre a constituição subjetiva de Nícolas, nos possibilita entender o quanto, lançar-se no desafio de assumir uma nova profissão aos 30 anos de idade, não se apresentava como algo complexo para ele. Sua compreensão era de uma continuidade, pois em ambas as profissões, tanto como pastor quanto como professor, o eixo central estava na ação de ensinar. Além disso, considerando que já havia tido várias circunstâncias em que ele próprio buscou viver algo diferente, o novo não o assustava, não o imobilizava. Ao contrário, o novo se constituía no desafio, na meta a ser superada, o que o colocava na circunstância de superar-se e desenvolver-se ao ver que conseguia alcançar os propósitos que assumia.

Nessa perspectiva, as interpretações acerca da constituição subjetiva de Nícolas nos enlaçam novamente com o conceito de sujeito:

Para González Rey, o sujeito emerge nas tensões dialéticas e dialógicas complexas urdidas entre as dimensões de sua subjetividade individual e a subjetividade produzida no contexto social vivido concretamente.

O sujeito do pensamento, da processualidade reflexiva, o senhor de sua vontade, de seu desejo, de sua emocionalidade, integra-se em uma mesma estrutura psíquica individual para representar a força de afirmação desse sujeito ativo presente na vida e no mundo. Somente esse sujeito da ação, que se expressa de forma intensa, viva, radical, pode, por meio de sua intencionalidade, romper com as condições estabelecidas historicamente em sua convivência social para transformar sua própria história. (ROSSATO; MARTINS; MITJÁNS MARTÍNEZ, 2014, p. 39) 
Nessa perspectiva, o percurso de Nícolas, da infância até o seu ingresso na docência, mostrou-nos o quanto viveu de maneira inquieta e, ao mesmo tempo, ativa os períodos da sua vida. Com certa frequência buscou mudanças em relação aos lugares onde residiu, tanto por decisões pessoais que tomou ante situações que vivia, quanto por curiosidade e vontade pessoal. Viver o novo parecia ser algo que o fazia sentir-se vivo e autoconfiante, percebendo que era capaz de resolver-se frente aos desafios que decidia enfrentar.

Entretanto, esse seu jeito de ser e de viver trazia certos problemas nas relações sociais, conforme abordamos em outros momentos. Sua convivência com os colegas da escola não era tranquila, mas acontecia permeada por conflitos, desencontros e posicionamentos divergentes ante as situações do cotidiano. Percebemos que esse processo gerava uma produção subjetiva de incômodo e inquietação em Nícolas frente à passividade, acomodação e entrega dos seus colegas de trabalho para com a rotina da vida docente, como se tudo acontecesse sempre da mesma maneira. Em uma das nossas entrevistas abordou essa questão, exaltando-se inclusive ao relatar uma conversa que teve com um colega:

"Por isso, todo ano pra mim é um desafio! Eu já estou terminando esse ano pensando: o que eu vou fazer de diferente no ano que vem? O que eu posso inserir de novo aqui dentro? Eu acho que..., porque até mesmo pra você não ficar viciado em fazer sempre as mesmas coisas. Eu vejo alguns colegas dizendo: 'Tudo de novo...'! Eu não! Cara, que tudo de novo? Tudo novo! Falei isso pro professor um dia desses: 'Não, cara, o ano que vem não vai ser tudo de novo! Viva o ano que vem, vai ser tudo novo! As caras são novas, os alunos são novos! Você tem que ser novo!' 'É..., mas eu sou o mesmo...' [...] Como você pode achar que você é o mesmo? Não. É falta de percepção da realidade sua, entendeu? A gente tem uma percepção errônea da nossa realidade. A gente pensa que todo mundo é igual, que todo ano é a mesma coisa. Não! Cada ano é uma sala diferente, alunos diferentes! E seus erros serão diferentes e seus acertos serão diferentes! Então nada é igual nunca! Só quando a gente está enfastiado, deprimindo que é tudo igual. ${ }^{52}$ ${ }^{52}$ Dinâmica conversacional sobre os registros no Diário "O cotidiano de um professor" $\left(1^{\circ}\right.$
encontro) -25.11 .15 . 
Identificamos também no completamento de frases alguns registros que evidenciaram esse posicionamento:

11. Ser professor é um desafio.

16. Meus alunos são desafiadores.

38. Minhas obrigações são prazerosas.

62. O trabalho é um prazer.

40. Eu brigo por pouca coisa.

Essas informações possibilitaram interpretar o quanto a compreensão de Nícolas sobre o seu trabalho era algo que potencializava situações de conflito na relação com os colegas. Isso porque era o espaço que Ihe trazia prazer e realização pessoal. Entretanto, não era qualquer trabalho, mas uma prática que tinha na sua base de sustentação a busca pelo novo e pelo desafio como algo inerente à profissão docente. Além disso, se integrava a isso ainda a maneira firme como colocava e defendia os seus posicionamentos. Essa postura potencializava as divergências e deixava os ânimos de alguns exaltados frente a um contexto social de desvalorização da profissão, principalmente em um ano de manifestações, reivindicações e greve dos professores.

A pouca articulação das pessoas para empreender processos de mudanças no seu cotidiano incomodava Nícolas, porém isso não o imobilizava. Se as pessoas não queriam acompanhá-lo, parecia se importar pouco com o que poderiam pensar ou falar sobre ele, pois tinha clareza do trajeto a percorrer. Além disso, sabia que assumir desafios daria trabalho e não seria fácil, afinal já havia vivido processos dessa natureza em vários momentos da sua vida. Em uma das entrevistas comentou sobre o que pensava em relação a como as pessoas o viam: 
"Quem me conhece, a primeira vista, pensa que eu sou um cara muito ditador, inflexível, muita gente já falou isso pra mim, entendeu. Muitos me acham inflexível, mas na verdade eu sou bastante flexível! Só me mostre, me convença de que eu preciso mudar e eu mudo. Eu não tenho problemas com mudanças! Agora, eu odeio mudanças só por mudanças! Tem que me convencer do porquê que eu preciso mudar! A partir do momento que eu fui convencido de que eu realmente preciso mudar, não tem problema nenhum. ${ }^{, 53}$

Interpretamos que as vivências de Nícolas ao longo da sua trajetória de vida o fortaleceram ante a situação de que, ao decidir por realizar uma mudança, era preciso planejamento, esforço e empenho pessoal para construir o caminho na perspectiva de alcançar os resultados almejados. Entretanto, importante era tomar a decisão pela mudança, uma situação que não acontecia ao acaso. Ao invés disso, para ele, essa questão estava relacionada a um processo de convencimento, de convicção de que a mudança era realmente importante. Esse processo implicava a reflexão, o levantamento de informações e a análise de possibilidades, tendo em vista se sentir seguro nas suas decisões em relação a vantagens, desvantagens e possíveis imprevistos que poderiam acontecer. Todo esse processo implicava também em algo intrínseco à mudança, implicava em uma postura de abertura frente ao novo.

Assim, viver situações de mudanças era algo que fazia parte da constituição subjetiva de Nícolas, acontecendo em virtude do seu olhar curioso e atento em relação à realidade. Interpretamos que as circunstâncias vividas na sua trajetória foram importantes e potencializadoras do processo de mudanças que buscou no seu percurso docente, vindo a tornar-se o professor que era no atual momento da sua vida. Conforme relatou, quando começou a exercer a docência, trabalhava de uma maneira bastante diferente em relação a como apresentamos e analisamos sua prática pedagógica e as relações sociais que estabelecia no seu cotidiano. Sobre isso, relatou o seguinte em uma das entrevistas:

\footnotetext{
53 Dinâmica conversacional sobre os registros no Diário "O cotidiano de um professor" $\left(2^{\circ}\right.$ encontro) - 16.12.15.
} 
"Então, o início da minha vida como professor, era o mais tradicional que você possa imaginar! [...] Eu era um professor diferente, extremamente tradicional e extremamente radical, daqueles que acreditava que o aluno que não aprende Biologia comigo, é porque ele era burro mesmo! E meninos burros têm que se lascar na vida, pois não querem nada! [...] Um professor totalmente dogmático! Dentro do contexto, só mudei o dogma da religião pro dogma da educação. Então continuei sendo dogmático, entendeu? Mas a minha cabeça não! Na minha cabeça eu não era nada dogmático, porque os dogmáticos eles não se consideram dogmáticos. Até mesmo porque o dogmatismo ele é... não sei se você sabe o que é o tapa-olho do cavalo? Mas... meu pai, como viveu em fazenda a vida inteira, então o cavalo coloca um tapa-olho assim. Então o dogmático..., eu acho que é perfeita a analogia para o cara que coloca um tapa-olho e não vê nada aqui, porque não existe nada aqui! Porque para o cavalo não deve existir nada aqui, deve existir apenas o que está à frente dele, o mundo é aquilo ali. Então eu achava isso aí! ${ }^{54}$

Foram surpreendentes as informações apresentadas por Nícolas em relação ao seu processo de mudanças como professor, pois foi inusitado imaginar que ele poderia ter sido algum dia um professor tradicional, radical e dogmático, conforme colocou. Na conversa que tivemos sobre o instrumento da Linha do Tempo, ele colocou que ingressou na docência aos 30 anos de idade e que, em torno de 41 anos, passou a ter uma nova visão de educação. Após dez anos de exercício da docência Nícolas fez modificações gradativas e impactantes na sua prática profissional. A maneira como realizava o seu trabalho, conforme apresentamos no decorrer desse capítulo, a partir do acompanhamento do seu cotidiano, revelaram a atuação de um professor com características distantes de uma atuação pedagógica tradicional. Frente a isso, foi instigante entender como esse processo aconteceu. A dúvida sobre o que aconteceu no seu percurso como professor, que o levou à transformação, foi respondida por ele próprio no momento em que relatou sobre esse fato na conversa que tivemos sobre a Linha do Tempo:

\footnotetext{
${ }^{54}$ Dinâmica conversacional sobre os registros na Linha do Tempo - 19.01.16.
} 
"Aí eu vim pro Tocantins e comecei minha jornada como professor aqui nessa escola, sempre foi aqui, apesar de que eu sai alguns anos. [...] Então ao longo desses últimos 20 anos eu estou ligado nessa escola aqui. O que mais? Então o início da minha vida como professor, o mais tradicional que você possa imaginar. Então coloco aqui o nascimento do meu primeiro filho, do meu segundo filho. Aí eu faço meu curso de Biologia, porque o meu curso de Biologia foi feito aqui no Tocantins. Nasce meu terceiro filho. [...] E aí eu fico com uma lacuna aqui, sem nada. [Referia-se à Linha do Tempo.] E aí eu falo: 'Não aconteceu nada na minha vida?' Por isso que eu acho importante fazer isso aqui. [Referia-se novamente à Linha do Tempo.] E aí eu falei pra mim: 'Meu Deus, minha vida virou um vazio em determinado momento? Não aconteceu nada de importante?' E aí eu coloco aqui: 41 anos, uma nova visão sobre a educação. Essa data que eu não sei se é exatamente, mas é aproximadamente por aqui que eu comecei a mudar. Eu digo que eu mudei como professor foi por aqui, mais ou menos. O que me levou a mudar como professor? Rubem Alves. Eu acho que eu não mudei apenas como professor! Rubem Alves me fez mudar como professor e como pai. Eu era um pai diferente, antes de Rubem Alves. Eu era um professor diferente, extremamente tradicional e extremamente radical. [...] Rubem Alves me mostrou que as coisas não são assim! Com Rubem Alves eu aprendi que, às vezes, quando um aluno se recusa a aprender, não é porque ele é burro, é porque ele é inteligente! Como assim? É! Um aluno inteligente, ele se recusa a aprender! Exatamente, ele se recusa a aprender algo que ele considera que é inútil! E quando você se recusa a aprender algo que você acha que é inútil, você é extremamente inteligente! Você é seletivo, você entende que o seu cérebro não precisa perder tempo com aquilo que é inútil. Então, isso se aplica a minha relação com os alunos, também se aplica a minha relação com os filhos. ${ }^{, 55}$

As reflexões de Nícolas nos permitem interpretar que ele vivia um período de maturidade profissional no atual momento da sua trajetória, o que entendemos que estava relacionado com a maneira como subjetivava as circunstâncias vividas. Considerando que, para ele, era importante alcançar as metas que assumia, viver a docência como um professor que não alcançava os alunos e que tinha resultados insatisfatórios com altos índices de reprovação, parece ter gerado certo desconforto no decorrer da primeira década da sua atuação na profissão. Evidenciamos um conjunto de registros nos indutores do completamento de frases que sinalizam que o fracasso se constituía em um

\footnotetext{
${ }^{55}$ Dinâmica conversacional sobre os registros na Linha do Tempo - 19.01.16.
} 
processo impulsionador de produção de sentidos subjetivos que mobilizava reflexões e ações no seu cotidiano:

8. Não posso fazer o impossível.

10. Eu preciso continuar tentando.

12. Fracassei muitas vezes na vida.

15. Eu gostaria de ser melhor.

21. Minha maior preocupação é não conseguir.

27. Fico triste com o fracasso.

35. Eu sempre posso melhorar.

36. Meu maior prazer é fazer bem feito.

50. Procuro dar o melhor de mim.

60. No passado fiz muita besteira.

O conjunto dessas informações nos permite interpretar que o seu olhar atento aos detalhes e sua postura questionadora e investigativa possibilitaram a abertura em relação a algo que poderia dar-lhe respostas para superar o fracasso, algo que não aceitava. Sentir-se fracassado em algo na vida era uma situação mobilizadora de ações de superação, pois gerava nele sentimentos de sofrimento e frustração que não queria viver.

Outro aspecto que podemos analisar na sua fala é o valor que ele atribuía à maneira como o aluno avaliava o seu trabalho como professor, que tipo de retorno ele percebia na maneira como participavam das suas aulas. Considerando que muitos alunos não alcançavam um bom resultado na aprendizagem da sua disciplina, isso indicava que não gostavam das suas aulas e que ele estava fracassando como professor. Entretanto, no início da carreira docente refletia sobre esse fato como sendo culpados os alunos que simplesmente não aprendiam, assim como pensavam vários dos seus colegas.

Contudo, sua postura inquieta e reflexiva o fez perceber que poderia haver outras possibilidades de respostas para entender esse problema, que, como ele colocou em um trecho anterior, era assumido por ele como um dogma. No momento em que entendeu, com Rubem Alves, que as pessoas 
são seletivas e fazem escolhas em relação ao que lhes é útil, parece ter gerado uma produção subjetiva em relação a querer que seus alunos considerassem as suas aulas como algo importante para suas vidas. Ele queria fazer parte do rol de conhecimentos que os alunos valorizavam e, em virtude disso, dedicavam-se e aprendiam. Frente a isso, parece ter concluído que, se permanecesse trabalhando da mesma maneira, continuaria excluído das escolhas dos seus alunos, processo que pode ter desencadeado o início das mudanças nas suas posturas docentes.

Compreendemos que esse processo de reflexibilidade colocava-o em uma posição de vigilância e autocrítica constante, pois, "por intermédio de seu pensamento e do exercício de novas práticas sociais, o sujeito enfrenta de forma permanente suas posições anteriores e se mostra com força em momentos de ruptura com o social, o que pode representar novos focos de subjetivação social” (GONZÁLEZ REY, 2005a, p. 240). Esse processo dinâmico e infinito possibilita que as pessoas se modifiquem, podendo inclusive vir a transformar os espaços sociais em que vivem.

Assim, a maneira como aconteceu o processo de mudanças na prática pedagógica de Nícolas não foi algo repentino. Ocorreu como resultado de um período de reflexões, leituras e estudos que fez a partir da indicação de Rubem Alves por um cunhado, que era professor de Filosofia, com quem tinha contatos esporádicos. Ele relatou ${ }^{56}$ que, em um dos encontros que tiveram, esse cunhado o comparou com Rubem Alves, referindo-se ao período em que o escritor atuou como Pastor Presbiteriano e interrompeu sua carreira em virtude de discordar dos dogmas da igreja, assim como aconteceu com Nícolas. Contou que, na ocasião, não deu importância e que, certo dia, estava em uma livraria e perguntou se tinha algum livro do autor a venda. Comprou, por curiosidade, começou a ler e, dessa forma, a mudança começou a acontecer, por meio de um processo de reflexões, conforme relatou:

"Aí li o primeiro livro e gostei muito! Poxa, esse cara que eu queria conhecer! Porque o Rubem Alves ele é um educador,

${ }^{56}$ Dinâmica conversacional sobre os registros na Linha do Tempo - 19.01.16. 
era professor lá na Unicamp, se eu não me engano, na Unicamp, e psicanalista, teólogo, filósofo. Poxa, esse cara tem tudo que eu gosto! E aí comecei a me apaixonar! Comecei a engolir os livros de Rubem Alves! Gostei muito, mudou. [...] Mas o que me levou a essa necessidade de romper com esses padrões, que são considerados como absolutos e inflexíveis foi Rubem Alves. Eu acho que Rubem Alves te leva realmente a questionar. O Rubem Alves não me ensinou uma fórmula. Rubem Alves me ensinou, me levou a me questionar, e quando você se questiona, você entende que você precisa mudar. Então eu acho que eu era um professor antes dele e sou um professor depois dele!"

A maneira como essa mudança aconteceu na vida de Nícolas evidenciou a intensidade de algumas questões analisadas anteriormente, como por exemplo: a importância que a leitura tinha na sua vida, sua iniciativa para buscar alternativas frente a situações que se sentia motivado, sua postura reflexiva e questionadora em relação a questões que o incomodavam e/ou inquietavam. Além disso, Rubem Alves parece ter sido considerado por Nícolas como o outro importante no seu processo de desenvolvimento pessoal, expressando inclusive que gostaria de tê-lo conhecido.

No ano em que a pesquisa foi realizada, ele já havia lido diversos livros do autor e, no decorrer das observações, em vários momentos, ele aproveitava o tempo do intervalo das aulas para ler. Isso indicou que há dez anos esse autor fazia parte das suas leituras, pois já estava na docência há vinte anos e o conheceu aproximadamente na metade desse percurso. Havia uma motivação intensa na construção autodidata que ele empreendeu na perspectiva de uma nova postura de vida pessoal e profissional a partir das leituras que realizava. $\mathrm{Na}$ conversa que tivemos no momento da construção interpretativa, voltamos a esse assunto e ele apresentou detalhes importantes sobre esse processo:

Nícolas: [...] Mas um dia, [...] eu tive acesso a uma obra do Rubem Alves, e achei muito interessante e comecei ver que o que o Rubem Alves falava tinha muito a ver com minha prática em sala de aula, incluindo os erros que eu estava cometendo. Eram erros absurdos! A minha concepção de aluno, a minha concepção do que é ser um professor estavam 
totalmente erradas! Eu percebi as minhas distorções na minha percepção como professor!

Pesquisadora: Você já estava incomodado com essas situações quando o Rubem Alves chegou na sua mão?

Nícolas: Já, muito! Já estava extremamente incomodado! A minha relação com os alunos, por ser um professor muito rígido, era extremamente conflituosa! [...] Então, quando a obra do Rubem Alves chegou na minha mão, eu tive essa reflexão do porquê do conflito!

Pesquisadora: Você já se perguntava isso?

Nícolas: Isso, já me perguntava! Qual é a solução? Porque eu acho que na vida você não deve se focar no problema, você deve se focar na solução. Só que pra mim não havia solução! $O$ problema estava neles, no aluno, e não em mim, entendeu! Então o Rubem Alves me mostrou que provavelmente o erro estava em mim e não no aluno! [...] E aí o Rubem Alves me mostrou: você tem que mudar! Você não pode mudar os outros, você só pode se mudar. Pronto! Descobri o segredo! Você não pode mudar o mundo, mas pode se mudar! Eu acho que quando você percebe isso fica fácil mudar. Porque o que eu vejo é que as pessoas querem mudar o mundo, o professor quer mudar os alunos. Você não vai mudar o aluno! Cara, se mude, porque talvez assim você possa mudar alguém pela influência, pelo que estão vendo em você, porque você é o modelo. Não é isso? É isso!

Pesquisadora: E aí você continuou lendo?

Nícolas: Ah, aí eu entrei de cabeça, né! Quando eu percebi que ele tinha algumas respostas, claro que ele não tinha todas as respostas, mas quando eu percebi que ele tinha algumas respostas eu quis conversar com ele. Vamos conversar, vamos sentar e conversar! Como eu não podia fazer isso pessoalmente, eu fiz isso com os livros e me tornei adepto dele. E sou até hoje, tenho livros dele pra ler até hoje!

Pesquisadora: E como foi mudar? Como foi isso para os alunos, para você?

Nícolas: Foi... a mudança foi gradativa. A mudança não foi brusca, foi gradativa, eu fui mudando aos pouquinhos... Um pouco hoje, um pouco amanhã, revendo algumas posturas hoje, outras amanhã. Foi um processo, isso foi um processo, não foi brusco! E continua sendo um processo! Não foi, continua sendo um processo! $O$ processo continua acontecendo, precisa continuar acontecendo! Quando pára de acontecer é porque eu preciso fazer algo de novo pra recomeçar novamente. Não pode parar, a vida não pára! $O$ universo não pára! O universo está em expansão. A Terra não pára de girar, nada pára. Então a gente também não pode parar $^{p^{7}}$

\footnotetext{
${ }^{57}$ Dinâmica conversacional durante o processo construtivo-interpretativo das informações da
} pesquisa - 16.05.16. 
Atribuímos à maneira como Nícolas viveu esse momento da sua vida profissional como uma situação de destaque no processo de construção interpretativa sobre a constituição da sua subjetividade. Os detalhes que apresentou nesse diálogo revelaram a postura autônoma, ativa e autodidata como empreendeu sozinho um processo de tornar-se um novo professor. Ele não participou de um curso, não teve uma orientação curricular pedagógica em relação ao que deveria aprender para mudar a sua prática. Ao invés disso, a produção subjetiva de incômodo, inquietação e frustração na convivência conflituosa com os seus alunos, mobilizaram nele o levantamento de perguntas. Algo deveria estar errado e ele precisava encontrar respostas. Uma situação que, para outros professores, muitas vezes gera o estresse, a desistência e o adoecimento, em Nícolas gerou uma produção de sentidos subjetivos que o mobilizaram para a ação. Precisava agir, não poderia ficar parado, ou seja, precisava mudar.

Sua disponibilidade para a mudança o colocou ante a situação da busca por algo novo e diferente em relação ao que fazia até aquele momento, pois permanecer da mesma maneira já sinalizava que seria incorrer no mesmo erro. Foi com essa plena abertura ao novo que aconteceu o encontro com os livros de Rubem Alves e a produção subjetiva de satisfação por ter encontrado possíveis respostas para suas angústias, motivou-o e mobilizou-o gradativamente para as ações de mudança. Considerando os vários momentos da pesquisa em que Nícolas atribuiu às provocações de Rubem Alves o fator que o levou à mudança, inferimos que essa foi uma importante contribuição. Entretanto, acreditamos que outros fatores também participaram e legitimaram esse processo, pois uma mudança como essa não acontece decorrente apenas de um fator. Apesar de voltarmos nesse assunto em momentos diferentes da pesquisa, as explicações eram recorrentes a esse fato.

Ainda sobre os processos subjetivos de Nícolas, finalizamos colocando que ele não estava parado no momento atual da sua vida profissional, mas projetava perspectivas de futuro para a sua carreira. 
Retomamos uma colocação citada por nós anteriormente, na qual entendemos que ele expressou a maneira como ele subjetivava o seu futuro:

"Acredito que ainda tenho uma jornada pela frente e espero que seja uma boa jornada! Vou fazer todo o possível pra que seja uma boa jornada [...]." ${ }^{58}$

No completamento de frases também fez alguns registros:

17. Meu futuro está em minhas mãos.

49. Minha vida futura depende de mim.

57. Necessito ampliar meus horizontes.

A prospecção que fazia para o seu futuro não era algo relacionado a uma espera pela aposentadoria, como presenciamos com o processo vivido por uma professora que se aposentou durante o período da pesquisa, ou de outros que ansiosamente contavam os anos para a chegada desse momento. Ao invés disso, em momentos distintos das dinâmicas conversacionais, Nícolas colocou que tinha duas situações nas quais ainda gostaria de trabalhar. Uma delas referia-se a atuar como Diretor de escola ${ }^{59}$. Contudo, ponderava que ainda não se sentia preparado, pois considerava que seu jeito de ser traria muitos problemas nas relações com os colegas e isso talvez fosse até prejudicial para a escola. A outra se referia a trabalhar como palestrante motivacional ${ }^{60}$, pois se realizava em poder ajudar as pessoas a encontrarem os seus caminhos e se sentirem felizes. Sobre essa atuação, além das construções interpretativas que elaboramos sobre a maneira como essa questão constituía a sua subjetividade, presenciamos um momento em que ele atuou especificamente nessa área. A convite da Coordenação

\footnotetext{
${ }^{58}$ Dinâmica conversacional durante o processo construtivo-interpretativo das informações da pesquisa - 16.05.16.

${ }^{59}$ Observação: Conselho de Classe - 24.11.15.

${ }^{60}$ Dinâmica conversacional sobre os registros no Diário "O cotidiano de um professor" $\left(2^{\circ}\right.$ encontro) - 16.12.15.
} 
Pedagógica, ele ministrou uma palestra aos alunos do $1^{\circ}$ ano ${ }^{61}$, motivando-os em relação aos estudos no Ensino Médio e suas perspectivas de futuro. Nesse momento observamos o quanto sua atuação nessa área era vivida com emocionalidade e envolvimento.

Frente ao exposto, interpretamos que as circunstâncias vividas por Nícolas e, por vezes, criadas por ele próprio, constituíram-se em processos de desenvolvimento da sua subjetividade, tornando-se um sujeito autônomo, ativo, crítico e decidido ante os desafios do cotidiano. As mudanças que ele empreendeu na sua vida mostraram que tinha uma capacidade geradora de possibilidades, pois sabia o que queria fazer e/ou alcançar. Frente a isso, construía o seu próprio caminho, articulando-se em relação às questões implicadas nos seus processos de mudança. Quando empreendeu o processo de modificações na carreira da docência alcançou uma mudança que o transformou em um professor mais aberto, flexível, que buscou desenvolver em si posturas na perspectiva de aproximar-se do universo dos seus alunos.

Portanto, a construção interpretativa das informações nos possibilita considerar que encontramos em Nícolas um processo de desenvolvimento da subjetividade na perspectiva de constituir-se enquanto sujeito da sua ação, o que se presentificava também nas suas intervenções pedagógicas. Concluímos que os constantes processos de via-a-ser e transformar-se estavam alicerçados na sua constituição subjetiva, que se configurava como uma força pessoal frente às circunstâncias vividas e the possibilitava dar saltos no seu desenvolvimento pessoal e profissional.

${ }^{61}$ Observação: palestra do Professor Nícolas para os alunos do 1ํano - 11.05.15. 
5 PRODUÇÃO TEÓRICA CONCLUSIVA 


\section{PRODUÇÃO TEÓRICA CONCLUSIVA}

A construção interpretativa que elaboramos sobre o caso do Professor Nícolas, apresentada no capítulo anterior, nos possibilita tecer algumas considerações teóricas que sistematizam sínteses conclusivas à luz do referencial teórico que adotamos para a realização da nossa pesquisa. Contudo, inicialmente é importante destacar que essa sistematização não assume o caráter de generalização de resultados sobre um professor, a serem utilizados, aplicados ou replicados em outras escolas.

Nossa pesquisa, fundamentada na Teoria da Subjetividade (GONZÁLEZ REY, 1997, 2004a, 2005a, 2005b, 2011b) e ancorada nos princípios da Epistemologia Qualitativa (GONZÁLEZ REY, 1997, 2002, 2005a, 2010, 2014a), busca contribuir com a produção científica na perspectiva de construir uma compreensão complexa e sensível sobre a subjetividade de um professor real, concreto e único, que vivia intensamente as relações sociais, a vida e a docência. Assim, as considerações que tecemos nesse momento não se apresentam como generalizações, mas como reflexões na perspectiva de problematizar a complexidade e singularidade das situações vividas nas relações sociais do cotidiano escolar.

Partindo de tais premissas, retomamos o objetivo geral da nossa pesquisa, o qual norteou o processo investigativo: analisar a constituição subjetiva do professor que se configura enquanto sujeito da sua ação. Destacamos que um dos principais desafios do momento empírico, na etapa da construção do cenário da pesquisa, foi a identificação e escolha dos professores que possibilitariam que a investigação acontecesse na perspectiva 
do objetivo proposto, conforme explicamos no capítulo metodológico ${ }^{62}$. Frente a isso, a opção pela análise do caso de Nícolas, em relação a outros professores que também participaram dos procedimentos empíricos, deu-se em virtude de possibilitar uma construção interpretativa na perspectiva de alcançar o objetivo da investigação.

No capítulo anterior mostramos que Nícolas era um professor que, assim como todas as pessoas, tinha suas potencialidades e fragilidades, e trabalhava em uma escola com os inúmeros desafios e problemas inerentes a essa profissão. Nosso foco não foi apresentar um professor perfeito e ideal, um modelo a ser seguido. Igualmente, e em conformidade com o referencial teórico que assumimos, não buscamos apresentar as características de um professor de sucesso ou de referência, como encontramos em publicações que realizam esse tipo de análise e categorização (ALBUQUERQUE, 2010; BÜHLER, 2010; CUNHA, 2000; FUKUDA; PASQUALI, 2002; MAJID; ALI; ALIAS, 2014; MAYNES; HATT, 2015; MILLER, 2012; MIRANDA, 2012; MIRON; MEVORACH, 2014; SANTOS, M. S., 2010; SILVA, S., 2014; SOUZA et al, 2009; TRAMMELL; ALDRICH, 2016; VLAD; CIASCAI, 2014). Além disso, a construção interpretativa não buscou apresentar e caracterizar um professor que era resiliente frente aos complexos desafios do contexto escolar. Ao invés de abordagens generalistas, padronizadas ou definidas a priori, nossa pesquisa buscou compreender a constituição subjetiva de um professor que, frente aos desafios do seu cotidiano, posicionava-se, tomava decisões, intervinha e agia, buscando alternativas ante as circunstâncias da profissão.

Assim, no decorrer da construção interpretativa sobre o caso do Professor Nícolas, evidenciamos que um professor que vive a docência com posturas ativas, autônomas, criativas e propositivas não se constitui repentinamente dessa maneira. Tal modo de ser e viver se constitui de forma processual ao longo da sua trajetória. Além disso, esse é um processo que não acontece somente no exercício da profissão, mas que faz parte da constituição histórica da vida, desde a infância até o momento atual, e que continua se configurando e reconfigurando ininterruptamente.

${ }^{62}$ Ver Capítulo III - Base epistemológica e metodológica. 
No capítulo anterior, várias informações evidenciaram que Nícolas apresentava posturas firmes, com segurança na defesa dos seus posicionamentos e nas decisões que tomava no cotidiano. Ele tinha clareza das metas que queria alcançar na sua vida e mobilizava-se para que acontecessem efetivamente. Esse processo o constituía desde a infância e adolescência até o seu momento atual, apresentando-se também na maneira como se organizava em relação as suas perspectivas de futuro. Assim sendo, consideramos que Nícolas constituía-se subjetivamente com elementos que integravam a sua configuração na perspectiva de possibilitar-Ihe se posicionar enquanto sujeito frente às situações e circunstâncias do seu cotidiano, tanto na vida pessoal quanto profissional. Retomando o nosso referencial teórico, González Rey (2007), define o sujeito

[...] como a pessoa capaz de gerar um espaço próprio de subjetivação em suas diferentes atividades humanas. $O$ sujeito é a pessoa apta a implicar sua ação no compromisso tenso e contraditório de sua subjetividade individual e da subjetividade social dominante. [...] O sujeito emerge na ação que vai além das normas formais estabelecidas, na possibilidade de gerar espaços próprios de subjetivação que lhe permitam um desenvolvimento diferenciado nos espaços da subjetividade social. [...] O se tornar sujeito significa expressar na ação configurações subjetivas singulares, tomar decisões, assumir a responsabilidade individual pela ação. (p. 144)

Nessa perspectiva, a postura ativa e propositiva como Nícolas vivia o cotidiano desafiador da docência, articulava-se com a compreensão que tinha em relação ao seu contexto de trabalho, o qual concebia como um espaço de possibilidades. Considerando a importância que a profissão tinha na sua vida, entendia que o seu local de trabalho era um espaço no qual era possível criar alternativas frente aos desafios e adversidades do cotidiano. Não se sentia imobilizado, fragilizado ou impossibilitado de agir, pois se percebia como parte integrante das situações que aconteciam no seu contexto profissional. Interpretamos que os processos subjetivos de identificação com a docência estavam imbricados com sentimentos de pertencimento e de 
comprometimento com a profissão, as pessoas e o espaço social no qual atuava como professor.

Assim, compreendemos que a maneira positiva, autônoma e criativa como Nícolas subjetivava as circunstâncias vividas, tanto na profissão quanto na vida pessoal, o mobilizava em prol de ações que planejava para enfrentar e superar as situações que dificultavam o alcance das metas estabelecidas. Com isso, interpretamos que a autodeterminação se constituía em um elemento subjetivo que possibilitava a proposição e realização de intervenções no seu cotidiano, configurando-se como uma força pessoal frente aos desafios vividos.

Entendemos que, ancorado a esse elemento subjetivo, estava o valor de destaque que Nícolas atribuía ao planejamento. Essa era a maneira por meio da qual ele se organizava para alcançar aquilo que almejava. A seleção e a escolha das prioridades para a sua intervenção perpassavam por uma postura sensível e atenta em relação aos acontecimentos do cotidiano, pelo levantamento de hipóteses explicativas e pela identificação de possíveis alternativas.

Além disso, Nícolas se abalava pouco com problemas que considerava pequenos ou triviais, nos quais seguidamente vários colegas se sentiam implicados. Igualmente não esperava que os outros fizessem algo que estivesse ao seu alcance. Ao invés disso, frente a situações que o incomodavam ou preocupavam, refletia sobre as possibilidades de intervenção, decidia e agia. Assim, interpretamos que a maneira como Nícolas subjetivava as circunstâncias do cotidiano evidenciava processos subjetivos de mobilização e articulação para resolver suas inquietações.

Consideramos ainda que Nícolas era seletivo em relação ao que considerava importante e necessário nas suas intervenções pedagógicas. Ele tinha clareza de que o processo de ensino e aprendizagem deveria superar a visão clássica da transmissão de conhecimentos. Ao invés disso, entendia que o professor tinha o importante papel de motivar seus alunos e organizar estratégias de ensino na perspectiva de promover o seu desenvolvimento, envolvendo-os no processo de aprendizagem. Nessa perspectiva, Nícolas 
assumia para si a responsabilidade de encontrar possibilidades frente às amarras do cotidiano. Ao criar situações motivadoras para os seus alunos, sobressaia-se com soluções criativas que lhe possibilitavam viver momentos de realização profissional.

Conforme discorremos no capítulo anterior, a construção das informações nos possibilitou interpretar que outro elemento subjetivo da constituição de Nícolas era a não aceitação do fracasso. Percebemos que ele observava e identificava as situações, refletia, se posicionava e agia. Esse processo demonstrava sua firmeza, sua segurança e a clareza que tinha em relação ao foco que queria alcançar, ou seja, a motivação e a aprendizagem dos seus alunos. Nessa perspectiva, construímos a hipótese interpretativa de que a maneira como se configurava a sua subjetividade possibilitou seu empoderamento no período em que empreendeu mudanças na sua prática pedagógica. A produção subjetiva gerada frente ao fracasso e a frustração de não alcançar resultados satisfatórios no seu trabalho, parece ter mobilizado nela a busca por soluções para superar a prática de aulas centradas na transmissão de conteúdos.

Ao realizar as mudanças na sua ação docente, emergiu outra possibilidade interpretativa. Entendemos que houve em Nícolas um movimento de desenvolvimento profissional, pois ele passou a valorizar os alunos e a entender quais eram os seus fatores motivacionais, modificando as suas aulas. Esse processo evidenciou que a autonomia se constituía em outro elemento subjetivo da configuração de Nícolas, pois, enquanto sujeito, agiu de maneira autodidata e independente e reconstruiu seus posicionamentos em relação ao papel do professor. Além disso, não se limitou a uma compreensão teórica, mas deu vida aos seus posicionamentos por meio do planejamento e da realização de aulas com estratégias metodológicas que possibilitavam relações sociais de proximidade com os alunos.

Compreendemos que a autonomia esteve presente como elemento subjetivo não somente na situação que destacamos. A maneira segura e ativa como Nícolas se posicionava, evidenciava sua postura autônoma e, inclusive, ousada, ao propor e criar caminhos e possibilidades 
frente a situações e desafios da vida pessoal e profissional. No contexto escolar, percebemos que esse seu jeito de ser e viver provocava incômodo em alguns colegas e, por vezes, trazia desconforto nas relações interpessoais. Além disso, a maneira contundente como se colocava, falava e se posicionava, tanto nas conversas informais quanto em momentos de reuniões ou decisões no cotidiano da escola, pareciam evidenciar certa radicalidade. Compreendemos que essas posturas não eram negativas, ao contrário, pareciam se constituir em uma força pessoal na maneira como vivia o cotidiano na perspectiva de alcançar seus objetivos e não fracassar.

Interpretamos que a gênese da constituição dos elementos subjetivos que possibilitavam a Nícolas a força pessoal de colocar-se enquanto sujeito frente aos desafios da docência remete-nos aos acontecimentos difíceis que Nícolas viveu em diferentes momentos da sua vida, conforme abordamos no capítulo anterior. Entendemos que ele precisou configurar-se subjetivamente com uma força pessoal em si para enfrentar os acontecimentos complicados, principalmente da adolescência e da juventude. Essa força parece ter se constituído como uma espécie de proteção pessoal ante os problemas. Nessa perspectiva, construímos a hipótese interpretativa de que a constituição subjetiva de Nícolas se configurou como uma força pessoal de enfrentamento e de empoderamento frente aos desafios da vida, possibilitando que ele se colocasse enquanto sujeito ante as circunstâncias e os problemas do cotidiano.

Assim sendo, entendemos que Nícolas subjetivava os desafios e impactos da vida como oportunidades de crescimento e desenvolvimento pessoal, pois não se fragilizava ou imobilizava ante os acontecimentos vividos. Ao invés disso, os impactos mobilizavam nele uma postura ativa de articular-se na perspectiva de encontrar soluções. Deduzimos que esse processo mobilizava em Nícolas um processo de produções subjetivas ante a circunstância do seu envolvimento emocional com os problemas e desafios do cotidiano. Ele vivia as relações sociais de maneira intensa, presente e atuante, apesar dos desconfortos e conflitos que as suas posturas firmes provocavam junto a alguns colegas de trabalho, conforme apresentamos no capítulo anterior. 
Assim, a maneira como Nícolas subjetivava os desafios do cotidiano enquanto oportunidades de crescimento e desenvolvimento potencializavam nele uma postura de abertura e flexibilidade na relação com as pessoas e nas possibilidades de mudanças. Ele tinha posturas radicais e firmes, ao mesmo tempo em que se dispunha e se permitia adentrar na relação social com abertura para rever seus posicionamentos, desde que se sentisse convencido de que essa seria uma decisão relevante. Assim, a trama complexa da constituição subjetiva de Nícolas nos colocou ante uma possibilidade interpretativa que evidenciou relações de contradição na configuração da sua subjetividade.

Dessa forma, compreendemos que, apesar das posturas firmes e, por vezes, radicais, sua constituição subjetiva Ihe possibilitava viver uma relação de alteridade com as pessoas do seu convívio social. No decorrer da sua história Nícolas teve marcas fortes de pessoas que ele reconhecia como o outro importante no seu processo de tornar-se quem era, conforme analisamos. Entendemos que, da mesma maneira, ele investia-se desse papel de ser o outro que poderia potencializar processos de desenvolvimento nos seus alunos e pessoas da sua convivência. Ele compreendia que um professor poderia contribuir na vida dos seus alunos e, com isso, valorizava as relações sociais estabelecidas no cotidiano.

Portanto, considerando a construção interpretativa que sistematizamos, concluímos que a complexa articulação entre os elementos da constituição subjetiva de Nícolas possibilitavam sua postura ativa, criativa, autônoma e propositiva ante os desafios da profissão, bem como sua abertura para situações de mudança. Compreendemos que os elementos participantes da sua configuração subjetiva se constituíram no decorrer da sua história de vida, possibilitando que ele atuasse e vivesse a docência assumindo-se enquanto sujeito da sua ação.

Considerando que a essência da profissão da docência é promover e alavancar processos de aprendizagem e desenvolvimento nos alunos, entendemos que, sem isso, a prática profissional não acontece 
efetivamente. Portanto, nessa perspectiva, elaboramos a construção interpretativa de que o professor que vive a docência enquanto sujeito se posiciona de forma clara, revê continuamente o foco do seu trabalho e se mobiliza em torno de ações e intervenções tendo em vista promover o desenvolvimento dos alunos, assumindo uma postura de reflexão constante sobre a sua atuação. Compreendemos que essa postura reflexiva não se limita aos processos cognitivos do pensar, mas integra as emoções que envolvem o professor com a sua profissão.

Entendemos que o professor que se constitui subjetivamente nessa perspectiva vive a relação pedagógica com um envolvimento simbólico e emocional de posturas e intervenções sensíveis, que the permitem captar o aluno nos processos subjetivos que integram o ensinar e o aprender. Nessa perspectiva, a construção interpretativa nos possibilita argumentar que, enquanto sujeito, o professor reflete e percebe-se a si mesmo, assim como passa a perceber o outro, no caso, o aluno. Assim, ao estabelecer-se uma relação social de proximidade e alteridade, é possível que o professor promova não só o desenvolvimento dos alunos, mas possa alavancar também que eles se constituam enquanto sujeitos do seu processo de aprendizagem e desenvolvimento.

Nessa perspectiva, compreendemos que a referência da atuação docente passaria a ser o aluno, nos processos subjetivos envolvidos nos seus percursos de aprendizagem, ao invés de uma expectativa pessoal previamente definida e que deveria ser alcançada. O movimento subjetivo do professor seria outro no momento do planejamento e na realização das aulas, pois sua constituição subjetiva enquanto sujeito possibilitaria que criasse e recriasse constantemente suas ações, permitindo e acolhendo a intervenção dos alunos. Suas intervenções aconteceriam assumindo uma postura investigativa em relação às produções subjetivas dos alunos no processo de aprendizagem, conforme defende Tacca (2009) em relação ao professor investigador.

Assim, investigar a produção de sentido subjetivo do aluno [...] é a alternativa para o professor que quer ser um investigador incansável, para uma compreensão adequada da trama 
complexa em que ocorrem a aprendizagem e o desenvolvimento. Com essas informações construídas com base na investigação dos processos de ser e aprender do aluno, ele poderá avançar em sua ação pedagógica. [...] $A$ base ou o objeto da investigação do professor estará nos sentidos subjetivos produzidos, porque, ali, estará a possibilidade de identificar os nexos e formas interfuncionais da unidade cognição-afeto. O instrumento metodológico básico para fazer emergir ou conhecer essa produção de sentidos subjetivos serão as situações dialógicas, pois somente com base nessas situações em que acontecem perguntas e respostas, que serão abertos os espaços para as expressões do sujeito. (p. 68-9)

Frente a tais conjecturas, retomando a construção interpretativa sobre o caso estudado, compreendemos que o Professor Nícolas tinha clareza da sua atuação, era seguro de si e sua prática profissional era adequada e criativa frente às demandas e desafios da docência. Entretanto, apesar disso, entendemos que ele ainda estava no processo de descobrir o seu aluno enquanto sujeito do próprio processo de aprendizagem e desenvolvimento. Suas intervenções pedagógicas evidenciavam a busca pela aproximação e o comprometimento com os seus alunos, entretanto pareceunos que assumia a referência de expectativas pessoais em relação a objetivar o aluno em torno de um padrão a ser alcançado. Conforme González Rey (2006),

O aluno torna-se sujeito da sua aprendizagem quando é capaz de desenvolver um roteiro diferenciado em relação ao que aprende e a se posicionar crítica e reflexivamente em relação à aprendizagem. Esse posicionamento só será possível na medida em que ele é capaz de gerar sentidos subjetivos em relação ao que aprende. (p. 40)

Nesse processo, Nícolas parecia ater-se pouco aos processos singulares e às produções subjetivas do aluno nos percursos de aprendizagem e desenvolvimento, perdendo a dimensão da sua processualidade enquanto sujeito que aprende (GONZÁLEZ REY, 2006, 2009b, 2012). A segurança que tinha nas suas propostas pareciam não lhe permitir subjetivar o aluno nos 
seus movimentos singulares no processo de aprendizagem e desenvolvimento.

Com isso, destacamos como é complexo compreender a constituição subjetiva do professor, pois esse é um estudo em movimento, em virtude de que o ser humano nunca se encontra pronto, acabado ou parado em um dado momento da sua vida. Apesar de concluirmos que encontramos em Nícolas um professor que se constituía subjetivamente na perspectiva de viver a docência enquanto sujeito, compreendemos que ainda havia movimentos na sua constituição subjetiva na perspectiva de alavancar seu próprio desenvolvimento pessoal e profissional.

Além dessa construção interpretativa, a pesquisa nos possibilitou concluir ainda que, atuar enquanto sujeito, não significa ser um professor plenamente feliz e satisfeito com a situação da profissão. Enquanto sujeito, o professor também desanima, cansa, reclama, se manifesta, participa de movimentos trabalhistas, etc. Contudo, apesar disso, quando está em sala de aula entende que o foco do seu trabalho é o aluno e, portanto, realiza suas ações com dedicação e comprometimento. Ele sabe com quem e em qual momento deve manifestar sua indignação e insatisfação em relação às situações que precisam melhorar na profissão, pois tem clareza de que o aluno não pode ser prejudicado.

Assim, compreendemos que agir e viver a docência dessa maneira se constitui como um processo constante de produções subjetivas do professor frente às circunstâncias vividas. Há professores que vivem intenso sofrimento frente às adversidades da docência, produzindo sentidos subjetivos relacionados a aproximarem-se ou distanciarem-se do aluno. Diversos professores subjetivam esse processo de tal maneira que vivem a profissão como algo a ser evitado, o que os leva a adoecerem, construírem outras perspectivas e, inclusive, mudarem de profissão. Contudo, o professor que se constitui enquanto sujeito atua na perspectiva de buscar alternativas para a satisfação pessoal e profissional, mesmo em meio aos problemas, assumindo posturas ativas e propositivas. Esse processo de produção subjetiva o fortalece em relação a querer 
permanecer na profissão, a recriar as suas práticas pedagógicas, a buscar e criar possibilidades para sua atuação junto ao aluno.

Deste modo, constituir-se como um professor que vive a docência enquanto sujeito articula-se com produções subjetivas que o docente elabora no curso da sua trajetória, incluindo nesse processo o valor que a profissão tem na sua vida. Tais produções subjetivas, que são únicas e singulares em cada pessoa, potencializam no professor o enfrentamento das adversidades do cotidiano e mobilizam a tomada de decisões em relação às intervenções pedagógicas que realiza, tendo em vista captar os seus alunos e possibilitar que eles também se constituam como sujeitos. 
CONSIDERAÇÕES FINAIS 


\section{CONSIDERAÇÕES FINAIS}

Escrever um texto que expresse de forma compreensível algo que não é simples, mas que é complexo, dinâmico e sistêmico, foi um dos principais desafios no processo de elaboração da tese. Evidenciar as interconexões da complexa tecitura da constituição subjetiva se apresenta como um processo desafiador para os pesquisadores que assumem sua investigação na perspectiva da Teoria da Subjetividade (GONZÁLEZ REY, 1997, 2004a, 2005a, 2005b, 2011b). Entendo que tal vivência contribuiu de maneira basilar na trajetória da minha constituição como pesquisadora da área da Educação, que ousou seguir seu percurso investigativo no campo científico de uma teoria psicológica complexa, por entender e valorizar sua contribuição frente a tantos desafios que o professor vive na sua profissão.

Destacamos que uma pesquisa como a nossa, que se propôs a analisar a constituição subjetiva de um professor, não consegue abarcar todos os elementos que constituem esse processo, pois a subjetividade é um sistema complexo, dinâmico, fluído e plurideterminado. O que apresentamos na construção interpretativa e aprofundamos na produção teórica são elementos subjetivos que constituíam o momento atual da subjetividade de Nícolas durante o período em que o acompanhamos no cotidiano do seu trabalho. Convém destacar que tais elementos foram construídos frente aos objetivos propostos e que certamente havia outros que seriam destacados em relação a outros temas ou objetivos.

Além disso, destacamos também que os elementos subjetivos que analisamos não são estáticos, mas modificam-se continuamente em virtude de integrarem as complexas interrelações que configuram a subjetividade como um sistema. Assim, entendemos que se fôssemos realizar a pesquisa novamente com o Professor Nícolas provavelmente a produção teórica teria outras possibilidades interpretativas, pois a subjetividade se 
reconfigura constantemente nos contínuos processos de produção subjetiva ante as circunstâncias da vida social.

Outra consideração que enfatizamos, é que viver a docência enquanto sujeito não torna o professor um profissional perfeito ou idealizado. Na nossa investigação não buscamos traçar um perfil com características para categorizar e identificar professores sujeitos e professores não sujeitos. Consideramos que, se analisássemos outros docentes também encontraríamos possibilidades para uma construção interpretativa sobre o nosso problema de pesquisa, as quais certamente seriam sistematizadas de outra maneira, pois a subjetividade se configura como um sistema complexo, único e singular.

Nessa perspectiva, a pesquisa nos possibilitou mostrar que, mesmo em meio a um momento de crise da profissão, de descrédito e desvalorização, mesmo em meio a relações sociais de pessimismo e desânimo, existem professores comprometidos com o foco principal da docência. Professores, que no dia-a-dia das escolas, realizam o seu trabalho sem a pretensão de destacarem-se por realizarem práticas pedagógicas inovadoras, mas que atuam na perspectiva de promover e alavancar o desenvolvimento dos seus alunos. Dar vida e voz a esses professores foi uma das intenções da nossa pesquisa, pois consideramos importante dar visibilidade à maneira como esses docentes se constituem subjetivamente possibilitando-Ihes agir e intervir frente às situações do cotidiano escolar.

Nessa perspectiva, considerando a produção teórica que elaboramos a partir da construção interpretativa, finalizamos apontando a contribuição da nossa pesquisa frente aos desafios da formação de professores. Consideramos que, estudar o professor na perspectiva da sua constituição subjetiva possibilita, tanto aos formadores, quanto aos diretores e coordenadores pedagógicos nas escolas, compreender que o desenvolvimento docente se constitui como um processo contínuo, dinâmico, fluído e complexo. O professor não está pronto em dado momento da sua vida profissional. Ao invés disso, é importante compreender que sempre há processos de desenvolvimento acontecendo ou por acontecer frente às produções subjetivas que se configuram e reconfiguram ininterruptamente. 
Nessa perspectiva, concordamos com L. S. Oliveira (2013; 2016) ao argumentar que a compreensão da formação docente na perspectiva da constituição subjetiva do professor nos desafia a entender, planejar e realizar processos em que ele é considerado como sujeito do seu percurso de formação. A autora argumenta que "são os processos de subjetivação do professor que podem favorecer sua implicação em ações formativas e no desenvolvimento do seu trabalho pedagógico" (idem, 2016, p. 162). O processo construtivo-interpretativo da nossa pesquisa nos possibilita complementar argumentando que, ao compreendermos os movimentos subjetivos do professor, seria possível sinalizar qual seria o seu próximo desenvolvimento, assim como ele precisa fazer com os seus alunos. Dessa forma, tal circunstância indicaria possibilidades para o planejamento e a realização de ações formativas assumindo como ponto de partida o processo de desenvolvimento do próprio professor.

Frente a isso, entendemos que se abrem novas zonas de sentido (GONZÁLEZ REY, 2005b) a serem investigadas por outros pesquisadores, pois ainda há inúmeros questionamentos perante os desafios da educação para os quais a Teoria da Subjetividade (GONZÁLEZ REY, 1997, 2004a, 2005a, 2005b, 2011b), uma teoria viva e em movimento, possibilita uma compreensão sistêmica e complexa. Em relação a nossa pesquisa, consideramos que uma importante questão que abre possibilidades de aprofundamento seria: como a relação pedagógica de um professor, que se constitui enquanto sujeito, poderia potencializar processos de desenvolvimento nos seus alunos na perspectiva de constituírem-se como sujeitos do seu processo de aprendizagem? Essa questão nos remete aos processos de formação docente e nos possibilita visualizar outro questionamento: de que maneira a relação pedagógica de formadores, diretores e coordenadores pedagógicos, que vivem a sua atuação profissional enquanto sujeitos, poderia potencializar processos de desenvolvimento nos professores?

Por fim, poderíamos seguir com um encadeamento de questões complexas que demandam interpretações e explicações igualmente complexas em virtude do contexto educacional que vivemos na docência. Colocar-se frente a esse desafio implica que nós, pesquisadores da educação, também 
vivamos a pesquisa assumindo-nos enquanto sujeitos, pois, ao nos colocarmos de maneira atenta, ativa e sensível frente às circunstâncias da investigação, torna-se possível interpretar os processos subjetivos que constituem as relações sociais do cotidiano escolar. 
REFERÊNCIAS 


\section{REFERÊNCIAS}

ALBUQUERQUE, Carlos Manuel de Sousa. Processo ensino-aprendizagem: características do professor eficaz. Revista Millenium. Viseu - Portugal, n. 39, Dezembro 2010, p. 55-71. Disponível em: <http://repositorio.ipv.pt/handle/10400.19/470>. Acesso em: 20 mai 2014.

ALTARUGIO, Maisa Helena. A posição subjetiva do formador na condução do processo reflexivo de professores de Ciências. 2007. $187 \mathrm{f}$. Tese (Doutorado) - Faculdade de Educação, Universidade de São Paulo, São Paulo, 2007. Disponível em: <http://www.teses.usp.br/teses/disponiveis/48/48134/tde26012009-150220/>. Acesso em: 19 jul. 2016.

AMARAL, Ana Luiza Snoeck Neiva do. A constituição da aprendizagem criativa no processo de desenvolvimento da subjetividade. 2011. $250 \mathrm{f}$. Tese (Doutorado) - Faculdade de Educação, Universidade de Brasília, Brasília, 2011. Disponível em:

$<$ http://repositorio.unb.br/bitstream/10482/9584/1/2011_AnaLuizaSnoeckNeivad oAmaral.pdf $>$. Acesso em: 15 jul. 2016.

ANDRADE, Eliane Righi de. Entre o desejo e a necessidade de aprender línguas: a construção das representações de língua e de aprendizagem do aluno-professor de língua inglesa. 2008. $278 \mathrm{f}$. Tese (Doutorado) - Instituto de Estudos da Linguagem, Universidade Estadual de Campinas, Campinas - SP, 2008. Disponível em:

$<\mathrm{http}: / /$ www.bibliotecadigital.unicamp.br/document/?code $=000436047>$. Acesso em: 20 jul. 2016.

ARRUDA, Tatiana Santos. A criatividade no trabalho pedagógico e o movimento em sua subjetividade. 2014. $270 \mathrm{f}$. Tese (Doutorado) Faculdade de Educação, Universidade de Brasília, Brasília, 2014. Disponível em: <http://repositorio.unb.br/handle/10482/17574>. Acesso em: 23 jul. 2016.

BARBIERI, Cesar Augustus S. O que é a escola? Os seus sentidos da antiguidade clássica até os nossos dias. Curitiba: CRV, 2011. 
BÜHLER, Caren. Bons professores que fazem a diferença na vida do aluno: saberes e práticas que caracterizam sua liderança. 2010. $170 \mathrm{f}$. Tese (Doutorado) - Faculdade de Educação, Pontifícia Universidade Católica do Rio Grande do Sul, Porto Alegre, 2010. Disponível em: < http://tede.pucrs.br/tde_busca/arquivo.php?codArquivo=2540>. Acesso em: 11 mai. 2014.

CARDOSO, Shirley Sheila. Subjetividade docente: identidade e trajetória do ser professor. 2014. 111 f. Dissertação (Mestrado) - Faculdade de Educação, Pontifícia Universidade Católica do Rio Grande do Sul, Porto Alegre, 2014. Disponível em: $<$ http://repositorio.pucrs.br/dspace/bitstream/10923/5672/1/000454709Texto\%2bCompleto-0.pdf>. Acesso em: 15 jul. 2016.

CARMO, Danielsie Silva do. "Eu sou professor": inconsciente, desejo e algumas questões sobre a formação. 2014. 71 f. Dissertação (Mestrado) Faculdade de Educação, Universidade Federal de Goiás, Goiânia - GO, 2014. Disponível em: <http://repositorio.bc.ufg.br/tede/handle/tede/4102>. Acesso em: 23 jul. 2016.

CORDEIRO, Renata Lopes. Dimensões subjetivas de professores de uma escola pública do Distrito Federal no contexto da educação inclusiva. 2015. 140 f. Dissertação (Mestrado) - Faculdade de Educação, Universidade de Brasília, Brasília, 2015. Disponível em: <http://repositorio.unb.br/handle/10482/19038>. Acesso em: 17 jul. 2016.

COSTA, Anderson da. Paris surrealista: errância, relevação e mito. Revista Estação Literária. Londrina, v.10A, p. 19-34, dez. 2012. Disponível em: <http://www.uel.br/pos/letras/EL/vagao/EL10A-Art2.pdf>. Acesso em: 12 jul. 2016.

COSTA, Aurea Júlia de Abreu. "Professora também sente": significados e sentidos sobre a afetividade na prática docente. 2012. 154 f. Dissertação (Mestrado) - Centro de Humanidades, Departamento de Psicologia, Universidade Federal do Ceará, 2012. Disponível em: <http://www.repositorio.ufc.br/handle/riufc/6813>. Acesso em: 20 jul. 2016.

COSTA, Marisa Vorraber. A escola rouba a cena! In: COSTA, Marisa Vorraber (org.). A escola tem futuro? 2.ed. Rio de Janeiro: Lamparina, 2007.

COSTAS, José Manuel Moran. A educação que desejamos: Novos desafios e como chegar lá. 5. ed. Campinas, SP: Papirus, 2011. 
CUNHA, Maria Isabel da. O bom professor e sua prática. 11.ed. Campinas, SP: Papirus, 2000.

DEMO, Pedro. Educação e conhecimento: Relação necessária, insuficiente e controversa. 3.ed. Petrópolis: Vozes, 2000.

DORNELLES, Marcia lara da Costa. Contribuições a uma proposta de formação de inteireza do professor de Matemática na perspectiva da complexidade. 2013. 148 f. Tese (Doutorado) - Faculdade de Educação, Pontifícia Universidade Católica do Rio Grande do Sul, Porto Alegre - RS, 2013. Disponível em: <http://hdl.handle.net/10923/2722>. Acesso em: 20 jul. 2016.

DRUMOND, José Cosme. Políticas de inovação educacional: subjetivação e modo de ser docente na escola plural. 2011. $287 \mathrm{f}$. Tese (Doutorado) Faculdade de Educação, Universidade Federal de Minas Gerais, Belo Horizonte - MG, 2011. Disponível em: <http://hdl.handle.net/1843/FAEC8M7JVS>. Acesso em: 19 jul. 2016.

FERREIRA, Aurélio Buarque de Holanda. Novo dicionário da Língua Portuguesa. 3.ed. Curitiba: Positivo, 2004.

FRIGOTTO, Gaudêncio; CIAVATTA, Maria. Educação básica no Brasil na década de 1990: subordinação ativa e consentida à lógica de mercado.

Educação e Sociedade. Campinas, v. 24, n. 82, p. 93-130, abr. 2003.

Disponível em: < http://www.scielo.br/pdf/es/v24n82/a05v24n82.pdf>. Acesso em: 18 mai. 2014.

FUKUDA, Cláudia Cristina; PASQUALI, Luiz. Professor eficaz: Um instrumento de aferição. Avaliação Psicológica. Itatiba - SP, n. 1, 2002, p. 1-16. Disponível em: < http://pepsic.bvsalud.org/pdf/avp/v1n1/v1n1a02.pdf>. Acesso em: 15 mai. 2014.

GADOTTI, Moacir. Da palavra a ação. In: INEP. Educação para todos: a avaliação da década. Brasília, DF: MEC/INEP, 2000.

\section{GALLERT, Adriana Ziemer. A produção de sentidos subjetivos dos} professores no enfrentamento das adversidades da docência. 2010. $202 \mathrm{f}$. Dissertação (Mestrado) - Faculdade de Educação, Universidade de Brasília, Brasília, 2010. Disponível em: $<$ http://repositorio.unb.br/bitstream/10482/7335/1/2010_AdrianaZiemerGallert.p df >. Acesso em: 5 jun. 2013. 
GALLERT, Adriana Ziemer; STÜRMER, Noeli Maria. Competências e habilidades: modismo ou inovação? Tempo Integral. Palmas, v.1, n.4, p. 1015, 2005.

GALLERT, Adriana Ziemer; TACCA, Maria Carmen Vilella da Rosa. A constituição da subjetividade do professor: um processo em permanente formação. In: QUADROS, Cristiane ; ROLIM, Carmen Lucia Artioli ; MÁRON, José Ramiro Lamadrid (Orgs.). Práticas Pedagógicas: construções do fazer docente. Goiânia: Kelps, 2012.

GAULEJAC, Vincent de; TAKEUTI, Tradução de Norma Missae. O âmago da discussão: da sociologia do indivíduo à sociologia do sujeito. Revista Cronos. Natal - RN, v. 5/6, n. 1/2, p. 59-77, jan./dez. 2004/2005. Disponível em: $<$ http://www.periodicos.ufrn.br/cronos/article/view/3233>. Acesso em: 04 Mar. 2014.

GONZÁLEZ REY, Fernando Luis. Epistemología cualitativa y subjetividad. São Paulo: EDUC, 1997.

Pesquisa qualitativa em psicologia: Caminhos e desafios. São Paulo: Pioneira Thomson Learning, 2002.

O social na psicologia e a psicologia social: a emergência do sujeito. Petrópolis, RJ: Vozes, 2004a.

O sujeito, a subjetividade e o outro na dialética complexa do desenvolvimento humano. In: SIMÃO, Lívia Mathias; MITJÁNS MARTÍNEZ, Albertina (Org.). $O$ outro no desenvolvimento humano: diálogos para a pesquisa e a prática profissional em psicologia. São Paulo: Pioneira Thomson Learning, 2004b.

O valor heurístico da subjetividade na investigação psicológica. In: GONZÁLEZ REY, Fernando (org.). Subjetividade, complexidade e pesquisa em psicologia. São Paulo: Pioneira Thomson Learning, 2005a.

Sujeito e subjetividade: uma aproximação histórico-cultural. São Paulo: Pioneira Thomson Learning, 2005b.

. O sujeito que aprende: desafios do desenvolvimento do tema da aprendizagem na psicologia e na prática pedagógica. In: TACCA, Maria Carmen Villella Rosa (org.). Aprendizagem e trabalho pedagógico. Campinas: Alínea, 2006. 
Psicoterapia, subjetividade e pós-modernidade: uma aproximação histórico-cultural. São Paulo: Thomson Learning, 2007.

. Epistemología y ontología: un debate necesario para la Psicología hoy. Revista Diversitas - Perspectivas en Psicología. Bogotá, Colômbia, v.5, n.2, p. 205-224, 2009a. Disponível em:

$<$ http://www.usta.edu.co/otraspaginas/diversitas/doc_pdf/diversitas_9/vol.5no.2/ articulo_1.pdf>. Acesso em: 10 jul. 2016.

. La significación de Vygotski para la consideración de lo afectivo en la educación: las bases para la cuestión de la subjetividad. Revista Electrónica Actualidades Investigativas en Educación. Costa Rica, v.9, p. 1-24, nov. 2009b. Disponível em: $<$ http://revistas.ucr.ac.cr/index.php/aie/article/view/9519>. Acesso em: 10 jul. 2016.

Pesquisa qualitativa e subjetividade: os processos de construção da informação. São Paulo: Cengage Learning, 2010.

El pensamiento de Vigotsky. Contradicciones, desdoblamientos y desarollo. México: Trillas, 2011a.

Subjetividade e saúde: superando a clínica da patologia. São Paulo: Cortez, 2011b.

A configuração subjetiva dos processos psíquicos: avançando na compreensão da aprendizagem como produção subjetiva. In: MITJÁNS MARTÍNEZ, Albertina; SCOZ, Beatriz Judith Lima; CASTANHO, Marisa Irene Siqueira. Ensino e aprendizagem: a subjetividade em foco. Brasília: Liber Livros, 2012.

. La subjetividad en una perspectiva cultural-historica: avanzando sobre un legado inconcluso. Revista CS. Cali, Colômbia. n. 11, p. 19-42, jan.jun. 2013a. Disponível em:

<http://www.icesi.edu.co/revistas/index.php/revista_cs/article/view/1565>. Acesso em: 10 jul. 2016.

O social como produção subjetiva: superando a dicotomia indivídiosociedade numa perspectiva histórico-cultural. Revista Ecos. Cáceres - MT, v.2, n. 2, p.167-185, 2013b. Disponível em:

$<$ http://www.uff.br/periodicoshumanas/index.php/ecos/article/view/1023>. Acesso em: 9 jul. 2016. 
. Ideias e modelos teóricos na pesquisa construtivo-interpretativa. In:

MITJÁNS MARTíNEZ, Albertina; NEUBERN, Maurício; MORI, Valéria D. (orgs.) Subjetividade contemporânea: discussões epistemológicas e metodológicas. Campinas, SP: Alínea, 2014a.

. A imaginação como produção subjetiva: as ideias e os modelos da produção intelectual. In: MITJÁNS MARTíNEZ, Albertina; ÁLVAREZ, Patrícia (orgs.). O sujeito que aprende: diálogo entre a psicanálise e o enfoque histórico-cultural. Brasília: Liber Livro, 2014b.

GONZÁLEZ REY, Fernando Luiz; MITJÁNS MARTÍNEZ, Albertina. Una epistemología para el estudio de la subjetividad: sus implicaciones metodológicas. Psicoperspectivas: individuo y sociedad. Chile, v.15, n.1, p. 516, 2016. Disponível em:

<http://www.psicoperspectivas.cl/index.php/psicoperspectivas/article/view/667>. Acesso em: 10 jul. 2016.

JOTZ, Claudia Beatriz. Produção de subjetividade na reflexão da prática docente através de grupo operativo sob a ótica sistêmica complexa. 2012. 145 f. Tese (Doutorado) - Faculdade de Psicologia, Universidade Católica do Rio Grande do Sul, Porto Alegre - RS, 2012. Disponível em: <http://hdl.handle.net/10923/4975>. Acesso em: 14 jul. 2016.

KENSKI, Vani Moreira. Em direção a uma ação docente mediada pelas tecnologias digitais. In: BARRETO, Raquel G. et. al. (org.) Tecnologias educacionais e educação a distância: avaliando políticas e práticas. 2.ed. Rio de Janeiro: Quartet, 2003.

Educação e tecnologias: o novo ritmo da informação. 9.ed.

Campinas: Papirus, 2012.

KHOURI, Mauro Michel El. Juventude, mídia e educação: novas tecnologias e produção de subjetividade em uma escola pública de Fortaleza. 2015. 158 f. Dissertação (Mestrado) - Centro de Humanidades, Departamento de Psicologia, Universidade Federal do Ceará, Fortaleza - CE, 2015. Disponível em: <http://www.repositorio.ufc.br/handle/riufc/12641>. Acesso em: 20 jul. 2016.

LAROUSSE CULTURAL. Grande Dicionário Larousse Cultural da Língua Portuguesa. São Paulo: Nova Cultural, 1999. 
LEITE, Carla de Meira. Possibilidades de produção subjetiva do professor de Educação Física em direção à perspectiva cultural: a experiência no currículo do Estado de São Paulo. 2015. 185 f. Tese (Doutorado) - Faculdade de Educação, Universidade de São Paulo, São Paulo, 2015. Disponível em: < http://www.teses.usp.br/teses/disponiveis/48/48134/tde-22062015-133906/>. Acesso em: 15 jul. 2016.

LIBÂNEO, José Carlos. As teorias pedagógicas modernas revisitadas pelo debate contemporâneo na educação. In: LIBÂNEO, José Carlos; SANTOS, Akiko (orgs.). Educação na era do conhecimento em rede e transdisciplinaridade. 3. ed. Campinas: Atomoealinea, 2010.

O dualismo perverso da escola pública brasileira: escola do conhecimento para os ricos, escola do acolhimento social para os pobres. Educação e Pesquisa, São Paulo, v. 38, n. 1, p. 13-28, 2012. Disponível em: <http://www.scielo.br/pdf/ep/v38n1/aop323.pdf>. Acesso em: 15 jun. 2014.

LIMA, Liliana Aparecida de. Os impactos das condições de trabalho sobre a subjetividade do professor de ensino superior privado de Campinas. 2012. 146 f. Tese (Doutorado) - Faculdade de Educação, Universidade Estadual de Campinas, Campinas - SP, 2012. Disponível em:

$<$ http://www.bibliotecadigital.unicamp.br/document/?code $=000905938>$. Acesso em: 17 jul. 2016.

MADEIRA COELHO, Cristina Massot. Sujeito, linguagem e aprendizagem. In: MITJÁNS MARTÍNEZ, Albertina; TACCA, Maria Carmen Villela Rosa. A complexidade da aprendizagem: destaque ao Ensino Superior. Campinas, SP: Alínea, 2009.

. Pesquisa em educação: desafios para a Epistemologia Qualitativa de González Rey. In: MITJÁNS MARTÍNEZ, Albertina; NEUBERN, Maurício; MORI, Valéria D. (orgs.) Subjetividade contemporânea: discussões epistemológicas e metodológicas. Campinas, SP: Alínea, 2014.

MAJID, Rosadah Abd; ALI, Manisah Mohd; ALIAS, Aliza. Teacher Character Strengths and Talent Development. International Education Studies. Toronto, Canadá, v.7, n.13, p.175-183, 2014. Disponível em:

<http://files.eric.ed.gov/fulltext/EJ1071186.pdf>. Acesso em: 10 jul. 2016. 
MAYNES, Nancy; HATT, Blaine E. Conceptualizing How Mature Teachers Can Influence Students' Growth in Learning. Brock Education: A Journal of

Educational Research and Practice. Ontario, Canadá, v.24, n.2, p.4-19, Set. 2015. Disponível em: <http://files.eric.ed.gov/fulltext/EJ1080019.pdf>. Acesso em: 10 jul. 2016.

MILLER, Patrícia. Ten Characteristics of a Good Teacher. English Teaching Forum. Washington, Estados Unidos, v.50, n.1, p.36-38, 2012. Disponível em: <http://files.eric.ed.gov/fulltext/EJ971241.pdf>. Acesso em: 10 jul. 2016.

MIRANDA, Simão de. Como se tornar um educador de sucesso: dicas, conselhos, propostas e ideias para potencializar a aprendizagem. 3.ed.

Petrópolis, RJ: Vozes, 2012.

MIRON, Mordechai; MEVORACH, Miriam. The "Good Professor" as Perceived by Experienced Teachers Who Are Graduate Students. Journal of Education and Training Studies. Beaverton, Estados Unidos, v.2, n.3, p. 82-87, Jul. 2014. Disponível em: <http://files.eric.ed.gov/fulltext/EJ1055497.pdf>. Acesso em: 10 jul. 2016.

MITJÁNS MARTÍNEZ, Albertina. El profesor como sujeito: elemento esencial de la formación de profesores para la educación inclusive. Movimento, Niterói - RJ, n. 7, p. 137-149, mai. 2003.

. Criatividade no trabalho pedagógico e criatividade na aprendizagem: uma relação necessária? In: TACCA, Maria Carmen Villella Rosa (org.). Aprendizagem e trabalho pedagógico. Campinas: Alínea, 2006. . Um dos desafios da Epistemologia Qualitativa: a criatividade do pesquisador. In: MITJÁNS MARTÍNEZ, Albertina; NEUBERN, Maurício; MORI, Valéria D. (orgs.) Subjetividade contemporânea: discussões epistemológicas e metodológicas. Campinas, SP: Alínea, 2014.

MORIN, Edgar. $O$ método 4: as ideias. Porto Alegre: Sulina, 1998.

O Método 5: a humanidade da humanidade. Porto Alegre: Sulina, 2005.

MORIN, Edgar; LE MOIGNE, Jean-Louis. A inteligência da complexidade. São Paulo: Petrópolis, 1999. 
NOGUEIRA SOBRINHA, Denise Elza. Vida, formação e educação: o curso de Pedagogia da Terra da Faculdade de Educação da UFG. 2012. $162 \mathrm{f}$.

Dissertação (Mestrado) - Faculdade de Educação, Universidade Federal de Goiás, Goiânia - GO, 2012. Disponível em:

<http://repositorio.bc.ufg.br/tede/handle/tde/2025>. Acesso em: 20 jul. 2016.

NÓVOA, António. O passado e o presente dos professores. In: NÓVOA, António (org.). Profissão professor. 2.ed. Porto, Portugal: Porto, 1995.

OLIVEIRA, Gilson Rocha de. A forja da alma: narrativas de docentes-mestres de jogos de RPG. 2012. 116 f. Dissertação (Mestrado) - Instituto de Ciências da Educação, Universidade Federal do Pará, Belém - PA, 2012. Disponível em: <http://www.ppged.com.br/bv/arquivos/File/dissertgilsonrocha.pdf>. Acesso em: 23 jul. 2016.

OLIVEIRA, Jezabel Gontijo Machado de. Trajetórias de constituição do ser docente. 2011. 139 f. Dissertação (Mestrado) - Faculdade de Educação, Universidade de Brasília, Brasília, 2011. Disponível em: <repositorio.unb.br/bitstream/10482/9537/.../2011_JezabelGontijoMachadodeOI iveira.pdf>. Acesso em: 21 jul. 2016.

OLIVEIRA, Luciana da Silva. O professor e sua formação: aspectos constitutivos desse processo. 2013. 183f. Dissertação (Mestrado em Educação) - Faculdade de Educação, Universidade de Brasília, Brasília, 2013. Disponível em:

$<$ http://repositorio.unb.br/bitstream/10482/16143/1/2014_LucianaSilvaOliveira.p df>. Acesso em: 30 jun. 2016.

Constituição subjetiva de professores: caminhos alternativos para a formação continuada. Curitiba: CRV, 2016.

PERRENOUD, Philippe. Construir as competências desde a escola. Porto Alegre: Artmed, 1999.

2000.

Dez novas competências para ensinar. Porto Alegre: Artmed,

RABELO, Amanda O. A remuneração do professor é alta ou baixa? Uma contraposição de diferentes referenciais. Educação em Revista. Belo Horizonte - MG, v.26, n.1, p. 57-88, abr. 2010. Disponível em: < http://www.scielo.br/pdf/edur/v26n1/04.pdf>. Acesso em: 23 mai. 2014. 
RANGEL, Mary. Supervisão: do sonho à ação - uma prática em transformação. In: FERREIRA, Naura Syria Carapeto. Supervisão educacional para uma escola de qualidade. 2.ed. São Paulo: Cortez, 2000.

REIS JÚNIOR, Osmar Domingos dos. Subjetividade e formação docente: os sentidos subjetivos que configuram o ver-se como professor. 2009. $129 \mathrm{f}$. Dissertação (Mestrado) - Centro de Ciências da Vida, Pontifícia Universidade Católica de Campinas, Campinas - SP, 2009. Disponível em: <http://tede.bibliotecadigital.puc-campinas.edu.br:8080/jspui/handle/tede/234>. Acesso em: 21 jul. 2016.

ROSA, Walquiria Miranda; SÁ, Carolina Mafra. História da feminização do magistério no Brasil: Uma revisão bibliográfica. Anais... III Congresso Brasileiro de História da Educação, Curitiba, 2004. Disponível em: < http://www.sbhe.org.br/novo/congressos/cbhe3/Documentos/Coord/Eixo5/477.p df>. Acesso em: 10 jun. 2014.

ROSÁRIO, Maria José Aviz do; SILVA José Carlos da. A educação jesuítica no Brasil Colônia. Anais... III Encontro de Pesquisa em Educação da UFPI e II Congresso Internacional em Educação, 2004. Disponível em:.

<http://www.ufpi.br/subsiteFiles/ppged/arquivos/files/eventos/evento2004/GT.11 /GT3.PDF>. Acesso em: 23 mai. 2014.

ROZEK, Marlene. Subjetividade, formação e educação especial: histórias de vida de professoras. 2010. 177 f. Tese (Doutorado) - Faculdade de Educação, Universidade Federal do Rio Grande do Sul, Porto Alegre, 2010. Disponível em: <http://hdl.handle.net/10183/21372>. Acesso em: 10 jul. 2016.

ROSSATO, Maristela; MARTINS, Luiz Roberto Rodrigues; MITJÁNS MARTÍNEZ, Albertina. A construção do cenário social da pesquisa no contexto da Epistemologia Qualitativa. In: MITJÁNS MARTÍNEZ, Albertina; NEUBERN, Maurício; MORI, Valéria D. (orgs.) Subjetividade contemporânea: discussões epistemológicas e metodológicas. Campinas, SP: Alínea, 2014.

SALUM, Ana Claudia Cunha. Redes virtuais de relacionamento: dispositivos de subjetivação, individuação e controle. 2012. 183 f. Tese (Doutorado) Instituto de Estudos da Linguagem, Universidade Estadual de Campinas, Campinas - SP, 2012. Disponível em:

$<$ http://www.bibliotecadigital.unicamp.br/document/?code $=000876103>$. Acesso em: 20 jul. 2016.

SANTOS, Boaventura de Sousa. Um discurso sobre as ciências. 5.ed. São Paulo: Cortez, 2008. 
SANTOS, Elzanir dos. Professores-estudantes e suas trajetórias: a construção de si como sujeitos da formação. 2010. 203 f. Tese (Doutorado) Faculdade de Educação, Universidade Federal do Ceará, Fortaleza - CE, 2010. Disponível em: <http://www.repositorio.ufc.br/handle/riufc/3301>. Acesso em: 19 jul. 2016.

SANTOS, Elias Batista dos. O professor em situação social de aprendizagem: autoctonia e formação docente. 2013. 285 f. Tese (Doutorado) - Faculdade de Educação, Universidade de Brasília, Brasília, 2013. Disponível em: <repositorio.unb.br/handle/10482/13823>. Acesso em: 16 jul. 2016.

SANTOS, Geandra Cláudia Silva. Os impactos na subjetividade do professor e a configuração do trabalho pedagógico com alunos que têm desenvolvimento atípico. 2010. $223 \mathrm{f}$. Tese (Doutorado) - Faculdade de Educação, Universidade de Brasília, Brasília, 2010. Disponível em: < repositorio.unb.br/bitstream/10482/8062/3/2010_GeandraClaudiaSilvaSantos.p df>. Acesso em: 15 jul. 2016.

SANTOS, Maricéa do Sacramento. Reflexões e prática de uma professora bem-sucedida. 2010. 191 f. Dissertação (Mestrado) - Departamento de Ciências da Educação, Universidade Federal de São João Del Rei, São João Del Rei - MG, 2010. Disponível em: < http://www.ufsj.edu.br/portal2repositorio/File/mestradoeducacao/Dissertacao\%20Maricea\%20do\%20Sacram ento\%20Santos.pdf >. Acesso em: 20 jul. 2016.

SAVIANI, Dermeval. História das ideias pedagógicas no Brasil. 3.ed. Campinas, SP: Autores Associados, 2011.

SIBILIA, Paula. Redes ou paredes: a escola em tempos de dispersão. Rio de Janeiro: Contraponto, 2012.

SILVA, Michela Tuchapesk da. A educação matemática e o cuidado de si: possibilidades foucaultianas. 2014. $193 \mathrm{f}$. Tese (Doutorado) - Instituto de Geociências e Ciências Exatas, Universidade Estadual Paulista "Júlio de Mesquita Filho", Rio Claro - SP, 2014. Disponível em: <http://hdl.handle.net/11449/127614>. Acesso em: 20 jul. 2016.

SILVA, Solimar. 50 atitudes do professor de sucesso. Petrópolis, RJ: Vozes, 2014. 
SOUZA, Ana Paula Gestoso de. et al. Saberes e fontes de aprendizagens de professoras consideradas como bem-sucedidas. Cadernos de Educação, Pelotas - RS, n. 34, p. 221-235, set./dez. 2009. Disponível em: < http://www2.ufpel.edu.br/fae/caduc/downloads/n34/14.pdf>. Acesso em: 17 abr. 2014.

SOUZA, Denis Mauro Rodrigues de. Professores de Educação Física em questão: corpo, relações de gênero e sexualidade. 2013. 132 f. Dissertação (Mestrado) - Faculdade de Educação, Universidade Federal de Juiz de Fora, Juiz de Fora - MG, 2013. Disponível em:

<https://repositorio.ufjf.br/jspui/handle/ufjf/1220>. Acesso em: 10 jul. 2016.

SOUZA, Elmara Pereira de. Cartografia da produção de subjetividade em ambiente virtual de aprendizagem para a formação de docentes online. 2013. 281 f. Tese (Doutorado) - Faculdade de Educação, Universidade Federal da Bahia, Salvador - BA, 2013. Disponível em:

<http://repositorio.ufba.br/ri/handle/ri/18167>. Acesso em: 19 jul. 2016.

SOUZA, Irene Garcia Costa de. Subjetivação docente: a singularidade constituída na relação entre o professor e a escola. 2012. 223 f. Tese (Doutorado) - Faculdade de Educação, Universidade de São Paulo, São Paulo, 2012. Disponível em: <http://www.teses.usp.br/teses/disponiveis/48/48134/tde16082012-114112/>. Acesso em: 15 jul. 2016.

TACCA, Maria Carmen Villella Rosa. Além de professor e de aluno: a alteridade nos processos de aprendizagem e desenvolvimento. In: SIMÃO, Lívia Mathias; MITJÁNS MARTÍNEZ, Albertina (Org.). O outro no desenvolvimento humano: diálogos para a pesquisa e a prática profissional em psicologia. São Paulo: Pioneira Thomson Learning, 2004.

. Estratégias Pedagógicas: conceituação e desdobramentos com o foco nas relações professor-aluno. In: TACCA, Maria Carmen Villella Rosa (org.). Aprendizagem e trabalho pedagógico. Campinas: Alínea, 2006.

O professor investigador: criando possibilidades para novas concepções e práticas sobre ensinar e aprender. In: MITJÁNS MARTíNEZ, Albertina; TACCA, Maria Carmen Villela Rosa. A complexidade da aprendizagem: destaque ao Ensino Superior. Campinas, SP: Alínea, 2009.

. Possibilidades da teoria Histórico-Cultural e da Subjetividade para Reflexões e Mudanças na Ação pedagógica de Professores. Intermeio, Campo Grande - MS, v. 21, 2015. 
TACCA, Maria Carmen Villela Rosa; GONZÁLEZ REY, Fernando Luis.

Produção de sentido subjetivo: as singularidades dos alunos no processo de aprender. Psicologia: Ciência e Profissão. Brasília - DF, 2008, v.28, n.1, p. 138-161, 2008. Disponível em:

<http://www.scielo.br/pdf/pcp/v28n1/v28n1a11.pdf>. Acesso em: 12 jul. 2016.

TELES, Ana Orofino. Por uma pedagogia com foco no sujeito: um estudo na Licenciatura em Educação do Campo. 2015. 222 f. Tese (Doutorado) Faculdade de Educação, Universidade de Brasília, Brasília, 2015. Disponível em: <http://repositorio.unb.br/handle/10482/19305>. Acesso em: 15 jul. 2016.

TOMANIK, Eduardo A. O sujeito humano e o conhecimento: constituição psicossocial e complexidade. In: TOMANIK, Eduardo A.; CANIATO, Angela Maria Pires; FACCI, Marilda Gonçalves Dias (orgs.). A constituição do sujeito e a historicidade. Campinas, SP: Alínea, 2009.

TOURAINE, Alain. Poderemos viver juntos?: iguais e diferentes. Petrópolis, RJ: Vozes, 1998.

. Convite. In: TOURAINE, Alain; KHOSROKHAVAR, Farhad. A busca de si: diálogo sobre o sujeito. Rio de Janeiro: Bertrand Brasil, 2004.

TOURAINE, Alain; KHOSROKHAVAR, Farhad. A busca de si: diálogo sobre o sujeito. Rio de Janeiro: Bertrand Brasil, 2004.

TRAMMELL, Beth A.; ALDRICH, Rosalie S. Undergraduate Students' Perspectives of Essential Instructor Qualities. Journal of the Scholarship of Teaching and Learning. Bloomington, Estados Unidos, v.16, n.1, p.15-30, Feb. 2016. Disponível em: <http://files.eric.ed.gov/fulltext/EJ1092406.pdf>. Acesso em: 10 jul. 2016.

TUNES, Elizabeth. É necessária a crítica radical à escola? In: Elizabeth Tunes. (Org.). Sem escola, sem documento. Rio de Janeiro: E-papers, 2011.

VALENTE, José Armando. As tecnologias e a verdadeira inovação. Pátio: Ensino Fundamental. Porto Alegre - RS, v. 14, p. 6-9, 2010.

VASCONCELOS, Maria Celi Chaves. Um estudo sobre a gênese da profissão docente. Poiésis Pedagógica. Catalão - GO, v. 2, n. 2, p.57-72, jan./dez. 2004. Disponível em: < http://www.revistas.ufg.br/index.php/poiesis/article/view/10522/6992>. Acesso em: 25 mai. 2014. 
VEIGA-NETO, Alfredo. Pensar a escola como uma instituição que pelo menos garanta a manutenção das conquistas fundamentais da modernidade. In:

COSTA, Marisa Vorraber (org.). A escola tem futuro? 2.ed. Rio de Janeiro: Lamparina, 2007.

VIGOTSKI, Liev Semionovich. Obras escogidas, Tomo III. Madrid: Ed. Visor, 1983.

Pensamento e linguagem. São Paulo: Martins Fontes, 1987.

Obras Escogidas V: Fundamentos de defectología. Madrid: Visor

Dis, 1997.

A formação social da mente. São Paulo: Martins Fontes, 1998.

Psicologia pedagógica. Porto Alegre: Artmed, 2003.

VILLELA, Heloisa de O. S. O mestre-escola e a professora. In: LOPES, Eliane Marta Teixeira. et al. $\mathbf{5 0 0}$ ano de educação no Brasil. 2.ed. Belo Horizonte: Autêntica, 2000.

VLAD, Iulia-Elena; CIASCAI, Liliana. Students' Perception of the Personal Characteristics of Ideal Teacher (I). Pilot Study. Acta Didactica Napocensia. Cluj-Napoca, Romênia, v.7, n.2, p. 41-47, 2014. Disponível em: <http://files.eric.ed.gov/fulltext/EJ1053282.pdf>. Acesso em: 10 jul. 2016.

ZOTTI, Solange. Sociedade, educação e currículo no Brasil: dos jesuítas aos anos 80. Quaestio: Revista de Estudos de Educação. Sorocaba - SP, v. 4, n. 2, nov. 2002. Disponível em: < http://periodicos.uniso.br/ojs/index.php?journal=quaestio\&page=article\&op=vie w\&path\%5B\%5D=1384\&path\%5B\%5D=1367>. Acesso em: 10 out. 2014. 
APÊNDICES 


\section{APÊNDICE I}

\section{OFICIO DE SOLICITAÇÃO DE AUTORIZAÇÃO PARA A REALIZAÇÃO DA PESQUISA}

Ao

Ilmo. Sr. Adão Francisco de Oliveira

Secretário de Educação

Secretaria de Educação do Tocantins

Palmas - TO, 23 de janeiro de 2015.

Prezado Senhor,

Venho por meio deste, apresentar-lhe o projeto de pesquisa do curso de Doutorado em Educação, que tem como título "A constituição subjetiva do professor como sujeito da sua ação pedagógica”, orientado pela Profa. Dra. Maria Carmen Villela da Rosa Tacca, da UnB - Universidade de Brasília. O projeto foi qualificado em banca em dezembro e encontra-se no período da pesquisa de campo. Assim, solicito sua autorização para a realização da pesquisa em uma escola da rede estadual, processo que deverá acontecer no decorrer do primeiro semestre do corrente ano com o acompanhamento do trabalho pedagógico dos professores, conforme explicado no extrato do projeto em anexo.

Em contrapartida à referida autorização, comprometo-me com a socialização dos resultados da pesquisa junto à escola e à Secretaria de Educação, como forma de agradecimento e contribuição com o aprimoramento da qualidade da educação no nosso Estado. 
Desde já agradeço e coloco-me à disposição para esclarecimentos e apresentação de detalhes sobre o projeto (contatos: telefone - (63)9215-8402; e-mail adrianagallert@gmail.com).

Adriana Ziemer Gallert

Pesquisadora 


\section{APÊNDICE II}

\section{TERMO DE CONSENTIMENTO LIVRE E ESCLARECIDO \\ RESOLUÇÃO CNS № 466/12}

Prezado(a) participante da pesquisa,

Estou desenvolvendo uma pesquisa que tem como título "A constituição subjetiva do professor como sujeito da sua ação". Esta pesquisa está vinculada ao meu Curso de Doutorado em Educação, na Universidade de Brasília - UnB, sob orientação da Profa. Dra. Maria Carmen Villela da Rosa Tacca.

O motivo que me leva a estudar sobre esse tema se justifica em virtude da preocupação que tenho em relação ao professor como profissional inserido no complexo contexto social e educacional do nosso momento histórico. Frente a isso, o objetivo desse projeto é analisar a constituição subjetiva de professores que se configuram como sujeitos da sua ação pedagógica.

Em virtude disso, você está sendo convidado(a) a participar deste estudo. Sua participação nessa pesquisa consistirá em colaborar com a realização de alguns procedimentos metodológicos, como por exemplo: entrevistas, observações, completamento de frases, dentre outros.

O benefício relacionado a sua participação será em colaborar com a ampliação de conhecimentos científicos para a área da educação, contribuindo com suas reflexões sobre o que pensa e como vive o seu trabalho como professor.

Esclareço que o seu nome não será revelado, a fim de garantir a sua privacidade, sendo a sua identidade preservada com padrões profissionais de sigilo. Você não será identificado(a) em nenhuma publicação que possa resultar deste estudo.

É importante que saiba que a sua participação neste estudo é completamente voluntária e que você pode recusar-se a participar ou interromper sua participação a qualquer momento sem penalidades ou perda de benefícios aos quais você tem direito. Você será esclarecido(a) sobre a pesquisa em qualquer aspecto que desejar. A participação no estudo não acarretará custos para você e não será disponível nenhuma compensação financeira adicional.

Coloco-me à disposição para qualquer esclarecimento acerca dos assuntos relacionados à pesquisa, no momento em que desejar, através do telefone (63)92158402. 
Solicito a sua assinatura neste consentimento, a fim de confirmar a sua compreensão em relação a este convite, e sua disposição em contribuir na realização do trabalho, em concordância com a Resolução do Conselho Nacional de Saúde № $466 / 12$, que regulamenta a realização de pesquisas envolvendo seres humanos. Caso tenha interesse em conhecer o texto da resolução você pode acessá-lo no link a seguir: <http://conselho.saude.gov.br/resolucoes/reso_96.htm>. Informo que uma cópia deste consentimento informado ficará guardado comigo e outra será fornecida a você.

Desde já, agradeço a sua atenção.

ADRIANA ZIEMER GALLERT

Pesquisadora

\section{DECLARAÇÃO DO PARTICIPANTE:}

$\mathrm{Eu}$,

fui informada(o) dos objetivos da pesquisa acima de maneira clara e detalhada e esclareci minhas dúvidas. Sei que em qualquer momento poderei solicitar novas informações e mudar a minha decisão, se assim o desejar. A pesquisadora Adriana Ziemer Gallert certificou-me de que todos os dados desta pesquisa serão confidenciais.

Declaro que concordo em participar desse estudo. Recebi uma cópia deste termo de consentimento livre e esclarecido e me foi dada a oportunidade de ler e esclarecer as minhas dúvidas.

Nome do Participante:

Assinatura:

Data: 


\section{APÊNDICE III}

\section{EIXOS PARA A DINÂMICA CONVERSACIONAL COM OS COORDENADORES PEDAGÓGICOS E A ORIENTAÇÃO EDUCACIONAL}

1. O que a escola espera do trabalho dos professores?

2. Como você percebe o grupo de professores em relação a essa expectativa?

3. Gostaria de conhecer o grupo de professores a partir do seu olhar. Poderia me falar sobre os professores que você acompanha? (Nesse momento da entrevista tínhamos uma lista com os nomes dos professores da escola e conversávamos sobre o grupo que trabalhava no turno matutino.) 


\section{APÊNDICE IV}

\section{EIXOS PARA A DINÂMICA CONVERSACIONAL COM O GRUPO DE PROFESSORES QUE NÃO PARTICIPOU DO MOVIMENTO DA GREVE}

1. Apresentação de cada professor em relação aos seguintes aspectos: formação acadêmica, tempo de experiência na docência, tempo de trabalho nessa escola, processo de escolha da profissão.

2. Motivos que mobilizaram os professores à greve.

3. Processo de adesão da escola em relação ao movimento.

4. Motivos que os levaram a não aderirem ao movimento da greve.

5. Como aconteceu esse processo de decisão na relação com os colegas que aderiram ao movimento.

6. Como se sentem em relação a esse processo.

7. O que pensam sobre o período após a greve em relação à convivência com os colegas.

8. Participação em outras greves no decorrer da sua trajetória profissional. 


\section{APÊNDICE V}

\section{EIXOS PARA A DINÂMICA CONVERSACIONAL COM OS PROFESSORES DO ESTUDO DE CASOS, ANTES DE INICIAR AS OBSERVAÇÕES DAS SUAS AULAS}

1. Trajetória pessoal de escolha da profissão: formação acadêmica, experiências profissionais, experiências na educação, motivos da escolha profissional, etc.

2. Experiências que marcaram positivamente a trajetória como professor.

3. Experiências que marcaram negativamente a trajetória como professor.

4. Desafios da profissão que o preocupam.

5. O que gosta na profissão.

6. O que não gosta na profissão.

7. Se pudesse mudar algo na sua trajetória de vida, o que mudaria.

8. Se tivesse que me apresentar o professor [nome do entrevistado], o que me falaria sobre ele.

Observação: Ao final dessa entrevista solicitava autorização para acompanhar o professor nas suas aulas. 


\section{APÊNDICE VI}

\section{COMPLETAMENTO DE FRASES}

Nome:

Idade:

Formação acadêmica - Graduação:

Ano de conclusão do curso:

Formação acadêmica - Especialização:

Ano de conclusão do curso:

Tempo de experiência profissional na educação:

Tempo de trabalho nessa escola:

Complete as frases de acordo com aquilo que você pensa neste momento em relação a sua profissão:

1. Eu gosto

2. O tempo mais feliz

3. Eu queria saber

4. Lamento

5. Meu maior medo

6. Eu sou

7. Na escola

8. Não posso

9. Sofro quando

10. Eu preciso

11. Ser professor

12. Fracassei 
13. A docência

14. Odeio

15. Eu gostaria

16. Meus alunos

17. Meu futuro

18. Minhas expectativas

19. Fico inconformado

20. Este lugar

21. Minha maior preocupação é

22. Desejo

23. Eu, secretamente,

24. O magistério

25. Meu maior problema

26. Espero

27. Fico triste

28. O estudo

29. Queria poder mudar

30. Amo

31. Esforço-me

32. Eu prefiro

33. Frustra-me

34. Minha principal ambição

35. Eu sempre posso

36. Meu maior prazer

37. Tentarei conseguir

38. Minhas obrigações

39. Fico feliz

40. Eu brigo

41. Os professores 
42. Sinto

43. Sempre quis

44. Quando estou sozinho

45. Não suporto

46. Não consigo

47. Minha sala de aula

48. O grupo

49. Minha vida futura

50. Procuro

51. De vez em quando penso

52. Meu maior desejo

53. Meu tempo

54. Luto

55. Atualmente o professor

56. Aborrece-me

57. Necessito

58. Alunos

59. Sempre que posso

60. No passado

61. Fico deprimido quando

62. O trabalho

63. Algumas vezes

64. Em casa

65. Quando posso

66. Minha maior frustração

67. Eu

68. Meus colegas

69. Penso

70. Tenho dúvidas 
71. Eu não quero

72. As pessoas

73. Eu sinto

74. Me dá trabalho

75. A educação 


\section{APÊNDICE VII}

DIÁRIO "O COTIDIANO DE UM PROFESSOR"

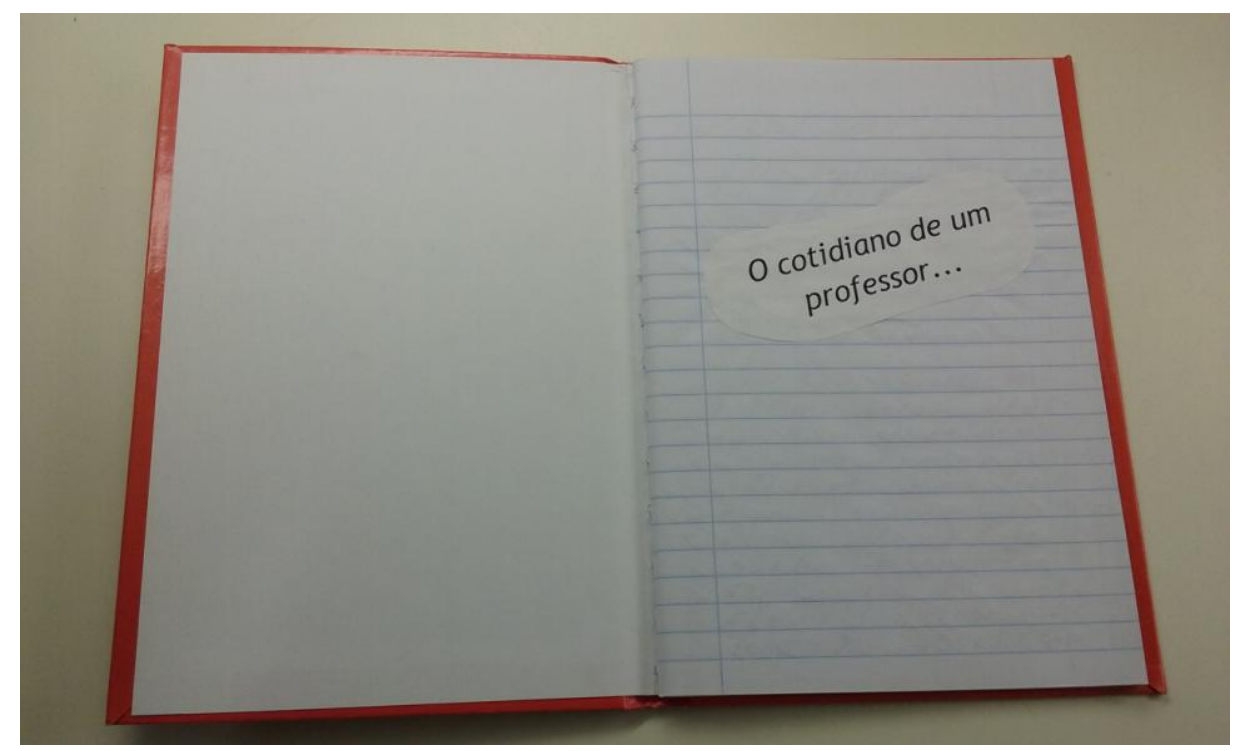




\section{APÊNDICE VIII}

\section{EIXOS PARA A DINÂMICA CONVERSACIONAL A PARTIR DOS REGISTROS NO DIÁRIO “O COTIDIANO DE UM PROFESSOR”}

Após um período em que os professores ficaram com o Diário "O cotidiano de um professor", agendamos um momento para conversar sobre os registros. Ao final da conversa sobre os seus registros, seguimos dialogando a partir do seguinte roteiro:

1. O que os alunos pensam sobre as suas aulas.

2. O que os alunos pensam sobre você como professor, como percebe isso.

3. O que os colegas pensam sobre as suas aulas e sobre a maneira como trabalha.

4. O que eles pensam sobre você como professor, sobre o seu jeito de ser professor; como percebe isso.

5. Como se vê no grupo de professores da escola; como se percebe em relação aos colegas.

6. Diferenciais no seu trabalho.

7. Alguma coisa que ainda gostaria de fazer na carreira como professor.

8. Alguma coisa que já fez e desistiu, ou talvez nunca tentou.

9. O que a vida significa.

10. O que a pesquisa significou.

11.Como se sentiu com a minha presença como pesquisadora. 


\section{APÈNDICE IX}

\section{LINHA DO TEMPO}

Observação: Para fins de registro, apresentamos um conjunto de fotos da Linha de Tempo elaborada pelo Professor Nícolas, porém o material foi preparado de forma contínua.
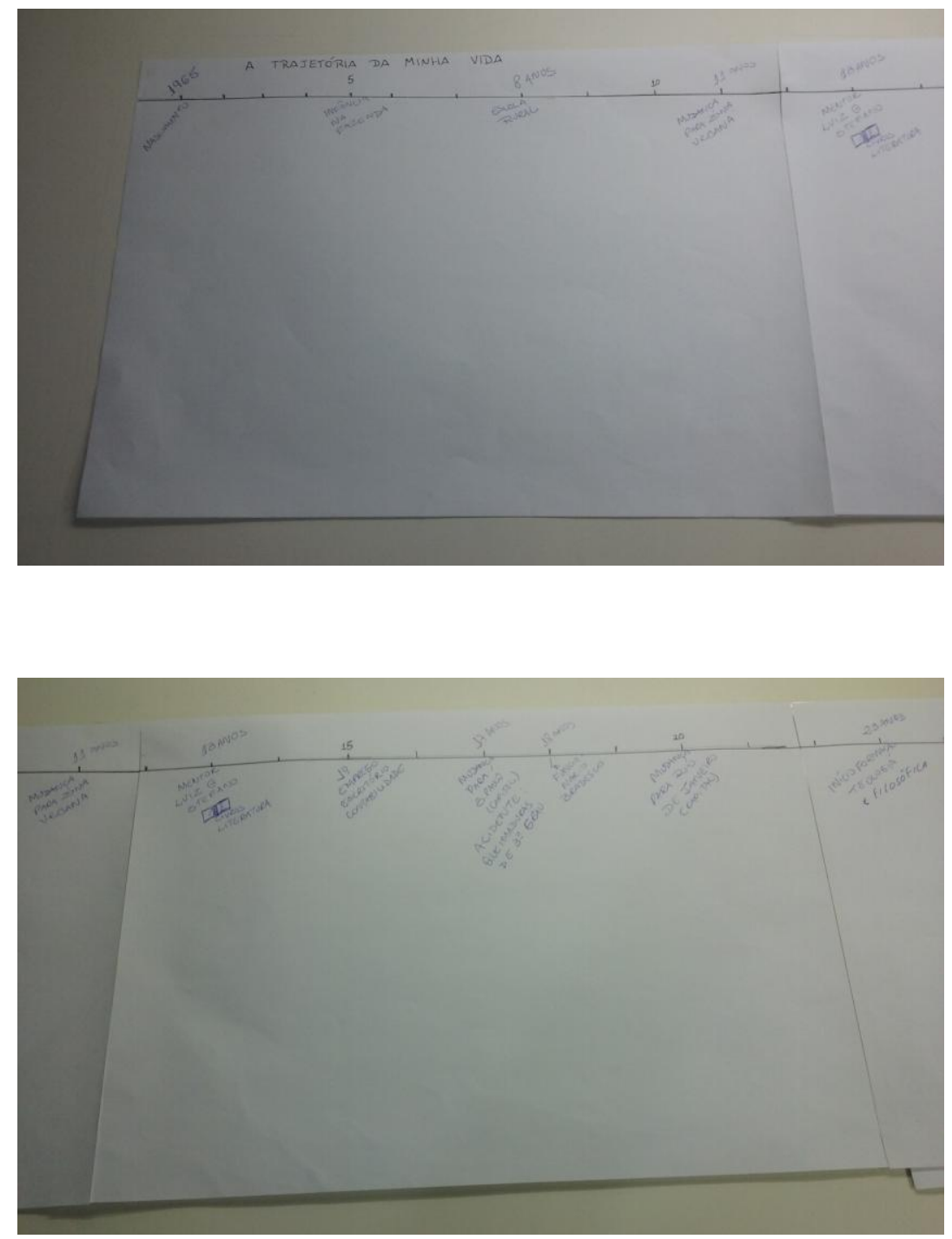

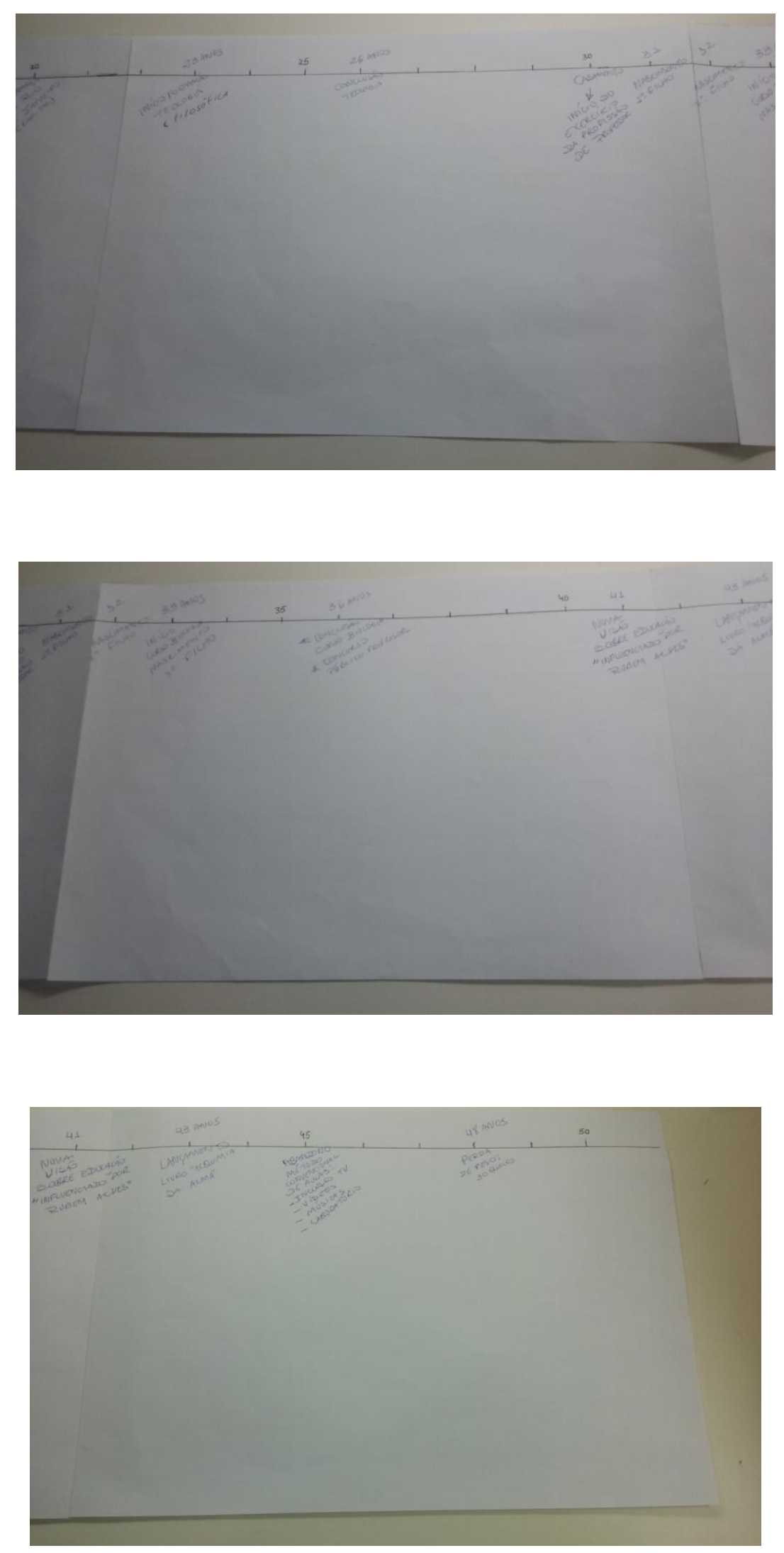


\section{APÊNDICE X}

\section{DINÂMICA CONVERSACIONAL A PARTIR DOS REGISTROS NA LINHA DO TEMPO}

O diálogo que aconteceu no encontro em que conversamos sobre os registros na Linha do Tempo não seguiu um roteiro previamente estabelecido. Ao invés disso, a proposta era uma conversa livre a partir dos destaques que os professores colocavam em relação aos registros dos fatos que consideravam importantes na sua trajetória de vida. 


\section{EIXOS PARA A DINÂMICA CONVERSACIONAL DURANTE O PROCESSO CONSTRUTIVO-INTERPRETATIVO COM A PARTICIPAÇÃO DO PROFESSOR NÍCOLAS}

Momento inicial: breve apresentação dos indicadores construídos pela pesquisadora sobre a constituição subjetiva do professor.

Eixos para o diálogo sobre momentos/fatos marcantes da história de vida do professor:

$\rightarrow$ Infância e pré-adolescência => Infância, família, escola, separação dos pais (11 anos).

$\rightarrow$ Mudança do interior de São Paulo para a Capital (17 anos) $=>$ Acidente de trabalho.

$\rightarrow$ Mudança para o Rio de Janeiro (20 anos).

$\rightarrow$ Mudança para o Paraná => estudos de Filosofia e Teologia, trabalho como Pastor Evangélico.

$\rightarrow$ Mudança para o Tocantins (30 anos) => Casamento, acompanha a esposa, torna-se professor.

$\rightarrow$ Mudanças na prática pedagógica. 